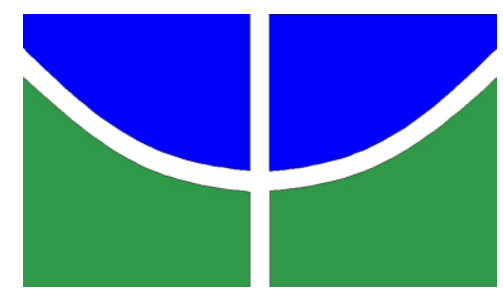

Universidade de Brasília

Instituto de Ciências Sociais

Departamento de Sociologia

Programa de Pós-Graduação em Sociologia

\title{
NARRATIVAS SOBRE A PROSTITUIÇÃO FEMININA NA W3 NORTE: CONSTRUINDO UM DISPOSITIVO
}

Autora: Cyntia Cristina de Carvalho e Silva

Brasília, dezembro de 2016. 


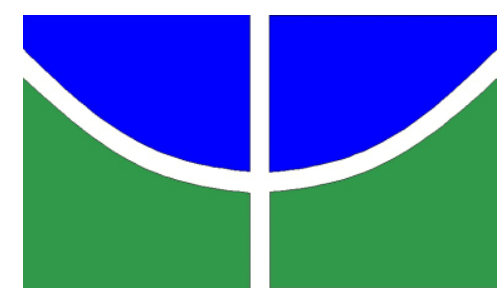

Universidade de Brasília

Instituto de Ciências Sociais

Departamento de Sociologia

Programa de Pós-Graduação em Sociologia

\title{
DISSERTAČ̃̃O DE MESTRADO
}

\section{NARRATIVAS SOBRE A PROSTITUIÇÃO FEMININA NA W3 NORTE: CONSTRUINDO UM DISPOSITIVO}

Autora: Cyntia Cristina de Carvalho e Silva

\begin{abstract}
Dissertação apresentada a banca examinadora, como requisito parcial de avaliação para obtenção do título de Mestre em Sociologia pela Universidade de Brasília.
\end{abstract}

Brasília, dezembro de 2016. 


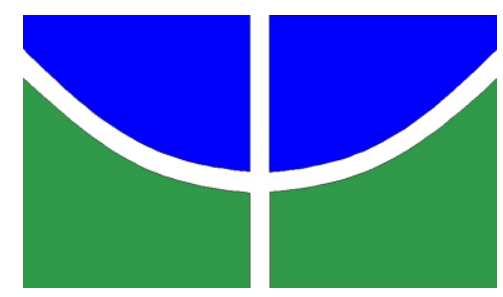

Universidade de Brasília

Instituto de Ciências Sociais

Departamento de Sociologia

Programa de Pós-Graduação em Sociologia

\title{
DISSERTAČ̃̃O DE MESTRADO
}

\section{NARRATIVAS SOBRE A PROSTITUIÇÃO FEMININA NA W3 NORTE: CONSTRUINDO UM DISPOSITIVO}

\author{
Autora: Cyntia Cristina de Carvalho e Silva \\ Orientadora: Profa. Dra. Haydée Glória Cruz Caruso (UnB) \\ Banca: Profa. Dra. Analia Laura Soria Batista (UnB) \\ Prof. Dr. Bruno Amaral Machado (UniCEUB) \\ Profa. Dra. Soraya Silveira Simões \\ (IPPUR/UFRJ)
}

Brasília, dezembro de 2016. 
Narrativas sobre a prostituição feminina na W3 norte: construindo um dispositivo.

Defesa de dissertação, apresentada à banca examinadora, como requisito final de avaliação para obtenção do título de Mestre em Sociologia pela Universidade de Brasília.

Banca Examinadora:

Profa. Dra. Haydée Glória Cruz Caruso (Orientadora) Departamento de Sociologia - SOL/UnB

Profa. Dra. Analia Laura Soria Batista (Examinadora) Departamento de Sociologia - SOL/UnB

Profa. Dr. Bruno Amaral Machado (Examinador) Departamento de Direito - UNICEUB)

Profa. Dra. Soraya Silveira Simões (Examinadora) Instituto de Pesquisa e Planejamento Urbano e Regional (IPPUR/UFRJ)

Data de aprovação:

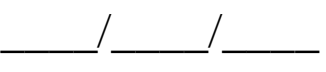


Ao Bê, meu amor. 


\section{Agradecimentos}

Por mais ricamente dotados que sejamos, sempre nos falta alguma coisa, e os melhores entre nós têm o sentimento de sua insuficiência. É por isso que procuramos, em nossos amigos, as qualidades que nos faltam, porque unindo-nos a eles participamos de certa forma da sua natureza e nos sentimos, então menos incompletos. Formam-se, assim, pequenas associações de amigos em que cada um tem seu papel conforme o seu caráter, em que há um verdadeiro intercâmbio de serviços. Um protege, o outro consola; este aconselha, aquele executa, e é essa partilha de funções, ou, para empregarmos a expressão consagrada, essa divisão do trabalho que determina essas relações de amizade. (...) Nesse caso, de fato, os serviços econômicos que ela pode prestar são pouca coisa em comparação com o efeito moral que ela produz, e sua verdadeira função é criar entre duas ou várias pessoas um sentimento de solidariedade. Como quer que esse resultado seja obtido, é ela que suscita essas sociedades de amigos, e ela as marca com seu cunho. (DURKHEIM, 2013, p.21).

É ancorando-me em Durkheim, um dos fundadores da Sociologia, essa área fascinante do conhecimento que nos ajuda a compreender sobre nós mesmos e como funcionamos em grupo, que começo meus infinitos e eternos agradecimentos a meus amigos, esses elementos heterogêneos que contribuem intermitentemente na formação do dispositivo que chamo de eu. Não fosse a esse sentimento de solidariedade e às interações com meus amigos, que os enxergo como flores, passarinhos e borboletas que enfeitam meu caminho ao longo dessa grande jornada, minha caminhada seria muito menos colorida e proveitosa. A incerta ou desconhecida destinação final da estrada, assim, perde a importância diante da riqueza que aprendo com os amigos, que são $100 \%$ do caminho.

Agradeço ao conforto da ideia do meu amigo Deus, que sempre me transmite a confiança de que tudo vai dar certo, independente das pedras e abismos do caminho. Agradecimento imenso também aos meus grandes amigos filósofos, sociólogos, juristas, psicólogos, matemáticos, físicos, enfim, todos aqueles que estudaram muito antes de mim e me deixaram muitos atalhos e dicas do caminho, como Foucault, Moscovici, Durkheim, Simmel, Bourdieu, Goffman, Becker, Lombroso, Hungria, Alan Turing, Santos Dumont, e tantos outros. Sem dúvidas, suas pegadas me conduziram a lindas ideias e paisagens.

Um especial e enorme muito obrigado a eles que me chamaram para viajar e compraram as passagens, meus grandes companheiros desde o início, meus queridos papai Arlindo e mamãe Mary. Sem vocês, nada teria acontecido. E, na mesma toada, um agradecimento do 
fundo do coração ao mais incrível companheiro de viagem, o Bê, que embarca em todas as minhas aventuras, tornando-as reais e mais coloridas. Obrigada pela intensa ajuda no trabalho e na vida. Admiro e amo muito você, Bê, e que viajemos juntos muito e muito mais.

Ao meu amigo, irmão do coração Ronaldo, pelas ideias, pelas incursões no campo e pelo seu sempre apoio incondicional. A meu grande amigo e interlocutor mais que qualificado Daniel, literalmente Augusto em vários sentidos, pela incrível amizade, pelas interações e provocações instigantes, pela correção e revisão. A Isabella, um enorme presente do mestrado, pela amizade, paciência, ideias, cupcakes, e as normas técnicas.

Muitos obrigadas aos meus grandes amigos Marina, Érica, Carol, Patrícia, Gustavo, pelas companhias de qualidade na minha vida e pela correção, revisão e ideias no texto. Agradecimentos do coração também aos meus amigos Daniela, Leonardo, Ellen, Marilza, Luiz, Aline, Angélica e seu papai querido Martin, que sempre me rodeiam com sua luz e conhecimentos. Gratidão ao Carlos e ao meu lindo e nerd primo Douglas e a querida Katharina. Muito obrigada a Fátima que acompanhou tudo bem de perto!

Um especial obrigada a minha querida orientadora Haydée Caruso, um exemplo de inteligência e perspicácia, responsável por me apresentar uma sociologia muito mais instigante e humana. Agradecimentos ao Instituto de Ciências Sociais da Universidade de Brasília, aos meus queridos professores, os quais encurtaram e iluminaram bastante meus caminhos, em especial, minha orientadora Haydée, prof. Ana Colares e prof. Carlos Benedito. Muito obrigada também a Paula, a Patrícia e a Gabriela pelo suporte na secretaria do curso e também aos meus queridos colegas do Mestrado.

Não posso deixar de agradecer ao prof. Bruno Amaral e à prof. Analia Soria, que participaram da minha banca de qualificação e colocaram holofotes e pavimentaram minha estrada. Gratidão aos colegas que participaram do Grupo de Trabalho: A gestão pública da prostituição, na 30ª Reunião Brasileira de Antropologia, em João Pessoa, pelas ideias incríveis que encheram meu caminho de balões coloridos de hélio! A estrada alcançou as nuvens! Obrigada a Dona Lu, a Carla, Luana e Isa pela carinhosa estada em João Pessoa.

Agradeço não apenas à instituição Polícia Civil do Distrito Federal, mas meus colegas que a compõe, pelos enormes aprendizados, inspirações, reflexões, dilemas e vivências, em especial ao Pedro, Ismael, Elisa, Danielle, Alexandre, Alex, Helder, William, Renato, Rodrigo Bonach e Nilton.

Obrigadas especiais aos meus interlocutores e entrevistados, as prostitutas da W3 norte, os clientes, os policiais civis e militares e também ao proprietário do site de acompanhantes. 


\section{Resumo}

A partir do conceito de dispositivo, desenvolvido por Michel Foucault, proponho a construção de um dispositivo para a prostituição feminina da avenida W3 norte, em Brasília/DF. Assim, analiso, por meio do conceito de representações sociais, de Serge Moscovici, a constante interação das narrativas morais, religiosas, médicas, jurídicas e sociológicas acerca da prostituição feminina com diversos elementos relacionados ao espaço da avenida W3 norte, captados por meio de observação flutuante.

Dessa forma, abordei as questões arquitetônicas e a apropriação do espaço pela prostituição feminina na avenida W3 norte; índices de criminalidade relacionada a esta atividade, entre os anos de 2010 a 2015, através da análise de ocorrências policiais registradas na Polícia Civil do Distrito Federal; entrevistas semiestruturadas com prostitutas, policiais militares e policiais civis que atuam na região, além de clientes do serviço. Ademais, considerei também a discussão da prostituição no campo feminista acadêmico e sua interação com os elementos coletados.

Ao final, diante de todos esses elementos heterogêneos foi possível indicar traços para um dispositivo da prostituição feminina da avenida W3 norte, caracterizado pelo intenso tráfego de veículos, pela separação espacial das atividades, pela cristalização de velhas representações sociais morais, religiosas, médicas, jurídicas e sociais sobre a prostituição feminina, pela objetivação das relações pessoais, discrição, praticidade e agilidade da atividade. Ademais, foi possível também constatar que a criminalidade associada à prostituição na W3 norte é pouco significante quando comparada aos registros totais de ocorrências policiais na área, o que demostra certa desproporcionalidade da rejeição social à atividade. Contudo, também identifiquei, em razão das características da prostituição no local, uma grande subnotificação de eventuais condutas criminosas relacionadas à atividade, principalmente quando as vítimas são as próprias prostitutas.

Palavras-chave: Prostituição Feminina, Dispositivo, Representações Sociais, Brasília. 


\begin{abstract}
Based on the concept of a dispositiv, developed by Michel Foucault, I propose the construction of a dispositiv for female prostitution on the north W3 Avenue, in Brasília/DF. Thus, I analyze, through the concept of social representations, by Serge Moscovici, the constant interaction of moral, religious, medical, juridical and sociological narratives about female prostitution with various elements related to the space of the north W3 avenue, captured through floating observation.

Thus, I dealt with architectural issues and appropriation of space for female prostitution on the north W3 Avenue; Crime rates related to this activity, between the years 2010 to 2015, through the analysis of police occurrences recorded in the Civil Police of the Federal District; Semi-structured interviews with prostitutes, military policemen and civilian policemen who work in the region, as well as clients of the service. In addition, I also considered the discussion of prostitution in the academic feminist field and its interaction with the collected elements.

In the end, in front of all these heterogeneous elements, it was possible to indicate traces of a feminine prostitution dispositiv of the north W3 avenue, characterized by intense vehicular traffic, spatial separation of activities, crystallization of old moral, religious, medical, legal, and social representations about female prostitution, through the objectification of personal relationships, discretion, practicality and agility of the activity. In addition, it was also possible to verify that the crime associated with prostitution in the north W3 is insignificant when compared to the total records of police occurrences in the area, which demonstrates a certain disproportionality of the social rejection to the activity. However, I have also identified, due to the characteristics of prostitution on the spot, a great underreporting of possible criminal conduct related to the activity, especially when the victims are the prostitutes themselves.
\end{abstract}

Keywords: Female Prostitution, Device, Social Representations, Brasília. 


\section{Résumé}

Partant du concept de dispositif, développé par Michel Foucault, je propose ici la construction d'une analyse utilisant ce concept appliqué à la prostitution féminine sur l'avenue W3 Nord, à Brasília, Distrito Federal. J'analyse par le biais du concept de représentation sociale de Serge Moscovci l'interaction constante des narratifs moraux, religieux, médicaux, juridiques et sociologiques autour de la prostitution féminine avec divers éléments liés à l'espace de l'avenue W3 Nord. J'utilise une observation flottante pour la collecte des données.

J'aborde les questions architecturales et l'appropriation de l'espace par la prostitution féminine sur l'avenue W3 Nord; les taux de criminalité liés à cette activité entre 2010 et 2015, grâce à une analyse des rapports de police remplis auprès de la Police civile (ocorrências policiais, en portugais) Civil du Distrito Federal; des entretiens semi-structurés avec des prostituées, des agents de police militaires et civils qui travaillent dans cette région, ainsi que des clients desservis. De plus, j'ai aussi pris en compte la discussion de la prostitution dans le milieu académique féministe et son interaction avec les éléments collectés.

Ainsi, face à tous ces éléments hétérogènes il m'est possible de brosser le tableau d'un dispositif de la prostitution féminine sur l'avenue W3 Nord, marqué par une circulation intense de véhicules, la séparation spatiale des activités, la cristallisation de vieilles représentations morales, religieuses, médicales, juridiques et sociales sur la prostitution féminine, par l'objectivation des relations personnelles, la discrétion, la praticité et la rapidité de l'activité. Par ailleurs je constate aussi que la criminalité associée à la prostitution sur la W3 Nord est peu significative quand comparée au nombre total des rapports policiers remplis dans la région. Ceci démontre une certaine disproportion du mépris social vis-à-vis l'activité en question. Cependant, j'ai pu également identifier, en raison des caractéristiques de la prostitution sur place, une importante sous-estimation d'éventuelles conduites criminelles liées à l'activité, surtout lorsque les victimes en question sont les prostituées elles-mêmes.

Mots-clés: Prostitution féminine, dispositif, représentations sociales, Brasília. 


\section{Resumen}

A partir del concepto de dispositivo, desarrollado por Michel Foucault, propongo la construcción de un dispositivo para la prostitución femenina de la avenida W3 Norte, en Brasília/DF. Así, analizo, por medio del concepto de representaciones sociales, de Serge Moscovici, la constante interacción de las narrativas morales, religiosas, médicas, jurídicas y sociológicas acerca de la prostitución femenina con diversos elementos relacionados al espacio de la avenida W3 Norte, captados por medio de la observación fluctuante.

De esa forma, abordaré cuestiones arquitectónicas y la apropiación del espacio por la prostitución femenina en la avenida W3 Norte, índices de criminalidad relacionados a esta actividad, entre los años 2010 y 2015, a través del análisis de ocurrencias policiales registradas en la Policía Civil del Distrito Federal; entrevistas semi-estructuradas con prostitutas, policías militares y policías civiles que actúan en la región, además de clientes del servicio. Consideré también la discusión de la prostitución en el campo académico feminista y su interacción con los elementos recolectados.

Al final, frente a todos estos elementos heterogéneos fue posible indicar trazos para un dispositivo de la prostitución femenina de la avenida W3 Norte, caracterizado por el intenso tráfico de vehículos, por la separación espacial de las actividades, por la cristalización de viejas representaciones sociales, morales, religiosas, médicas, jurídicas y sociales sobre la prostitución femenina, por la objetivación de las relaciones personales, discreción, practicidad y agilidad de la actividad. Además fue posible también constatar que la criminalidad asociada a la prostitución en la W3 Norte es poco significante comparada con los registros totales de ocurrencias policiales en el área, lo que demuestra cierta desproporcionalidad del rechazo social a la actividad. Con todo, también identifiqué, en razón de las características de la prostitución en este local, una grande subnotificación de eventuales conductas criminosas relacionadas a la actividad, principalmente cuando las víctimas son las propias prostitutas.

Palabras clave: Prostitución femenina, Dispositivo, Representaciones Sociales, Brasília. 


\section{Zusammenfassung}

Anhand des von Michel Foucault geprägten Begriffs "Dispositiv" wird ein Dispostiv in Bezug auf die auf der W3 Allee (Brasilia/DF) existierende weibliche Prostituition konstruiert. Durch den von Serge Moscovici eingeführten Begriff "soziale Repräsentation" analysiere ich daraufhin die dauernden Interaktionen zwischen moralisch-, religiös-, medizinisch-, juristichund soziologischen Erzählungen über die weibliche Prostituition mit ihren verschiedenen Komponenten des W3 norte Allee-Raumes.

Mit dieser Perspektive spreche ich die architektonischen Fragen und den von der weiblichen Prostitution auf der W3 norte-Allee in Anspruch genommenen Raum an. Die auf der Analyse polizeilicher Anzeigen der Polícia Civil do Distrito Federal basierende Kriminalitätsstatistik dieser Tätigkeit in den Jahren 2010-2015 und Interviews mit Prostituierten, Polizeibeamten, die in der Region tätig sind, und Kunden des Geschäfts wurden berücksichtigt. Darüber hinaus bezog ich die feministische Diskussion im Forschungsfeld der Prostituition und seine Interkationen mit den während der Forschung gesammelten Elementen ein.

Schließlich wurden hinsichtlich aller heterogenen Elemente die Merkmale eines Dipositivs für die weibliche Prostitution auf der W3 norte-Allee gezeigt, deren Besonderheiten das starke Verkehrsaufkommen, die räumliche Trennung der Tätigkeiten, die Kristallisierungen alter sozial-, moralisch-, religiös-, medizinisch-, juristichen Repräsentationen von weiblichen Prostitution, die Verdinglichung persönlicher Beziehungen und Diskretion, Durchführbarkeit, Behändigkeit sind. Außerdem war es möglich zu bemerken, dass die existierende Kriminalität, die sich auf die Prostitution bezieht, geringfügig ist, wenn man alle polizeilichen Anzeigen im Auge hat. Das zeigt eine gewisse Unverhältnismäßigkeit des gesellschaftlichen Verwerfens. Aufgrund der Merkmale von der im Orte praktizierten Prostitution identifizierte ich trotzdem eine geringe Zahl von polizeilichen Anzeigen, die sich auf diese Handlung beziehen, insbesondere wenn es im konkreten Fall um die Prostituierten als Opfer geht.

Stichwörter: weibliche Prostitution; Dispositiv; soziale Repräsentationen; Brasília. 


\section{Lista de siglas e abreviações}

ADI - Ação direta de inconstitucionalidade

ADPF - Ação de descumprimento de preceito fundamental

CC - Código Civil

$\mathrm{CP}$ - Código Penal

DEAM - Delegacia de Atendimento à Mulher

DF - Distrito Federal

DP - Delegacia de Polícia

GTOP - Grupo Tático Operacional

MJ - Ministério da Justiça

MTE - Ministério do Trabalho e Emprego

PCDF - Polícia Civil do Distrito Federal

PMDF - Polícia Militar do Distrito Federal

STJ - Superior Tribunal de Justiça

STF - Supremo Tribunal Federal 


\section{Índice de tabelas}

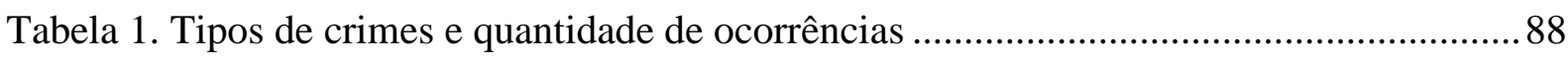

Tabela 2. Relação entre o tipo de crime e a participação da prostituta ...................................91

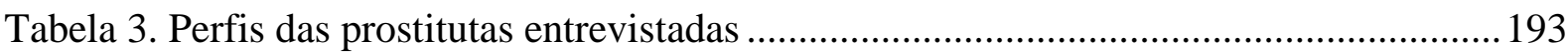

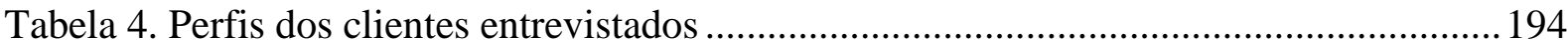

\section{Índice de figuras}

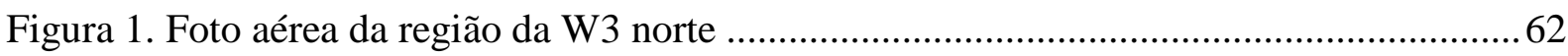

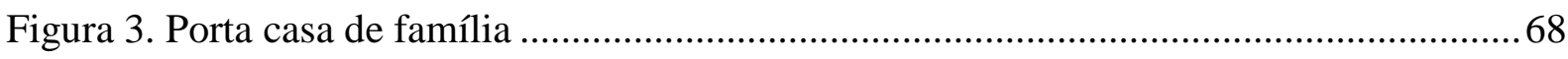

Figura 4. Faixas de protesto dos moradores da 715 norte para protestar contra a presença das prostitutas.

\section{Índice de gráficos}

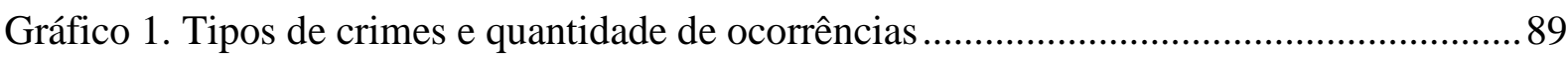

Gráfico 2. Tipos de participação das prostitutas em crimes ...................................................92

Gráfico 3. Prostituta como vítima por tipo de crime ............................................................ 93

Gráfico 4. Prostituta como testemunha por tipo de crime ......................................................93

Gráfico 5. Prostituta como autora por tipo de crime ............................................................... 93

Gráfico 6. Relação entre o tipo de crime e a participação da prostituta ....................................94 


\section{Sumário}

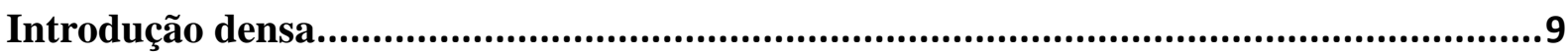

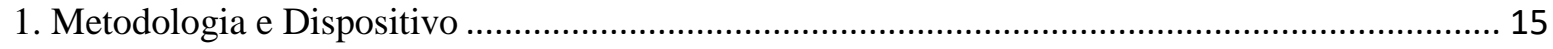

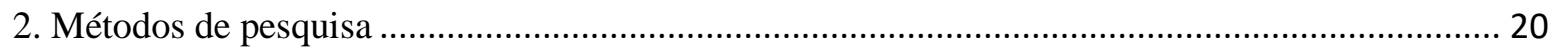

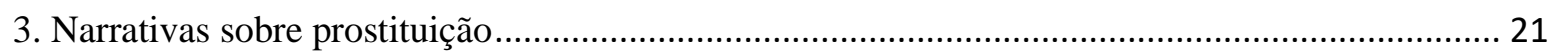

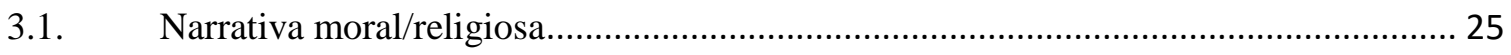

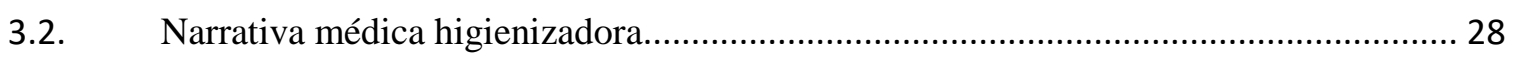

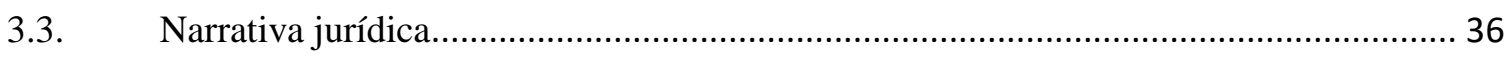

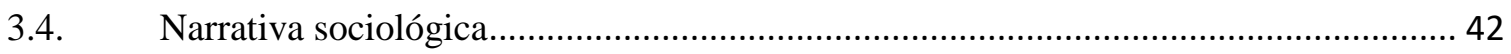

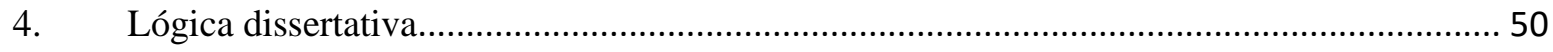

Capítulo 1 - A prostituição e a W3 norte ...............................................................52

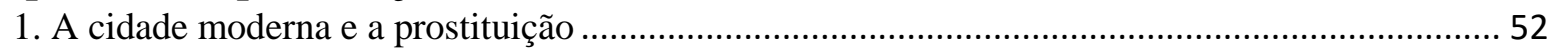

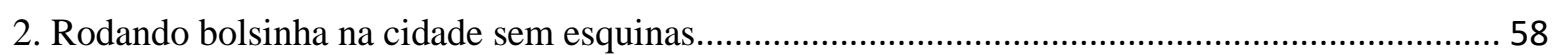

3. A apropriação do espaço e a dinâmica da prostituição na W3 norte............................................. 64

4. Notas para um dispositivo espacial da prostituição na avenida W3 norte ..................................... 74

Capítulo 2. A criminalidade e a prostituição na w3 norte ............................................76

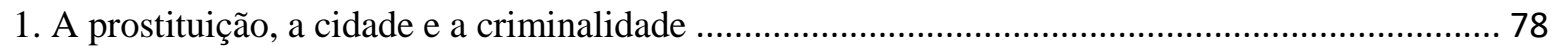

2. O registro das ocorrências policiais na área da W3 norte ........................................................... 82

3. A análise das ocorrências policiais na área da W3 norte ....................Erro! Indicador não definido.

4. Notas para um dispositivo de prostituição, cidade e criminalidade na W3 norte......................... 99

Capítulo 3. "Luz na passarela que lá vem elas" - As prostitutas da W3 norte.............. 102

1. Vencendo moinhos - percursos metodológicos de entrevista com as prostitutas da W3 norte .. 102

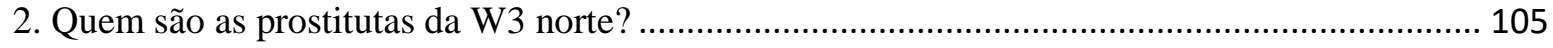

3. A prostituição na W3 norte na versão das suas protagonistas.................................................... 110

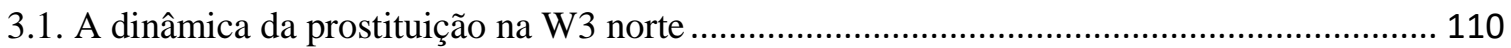

3.2. A prostituição como um trabalho, uma atividade profissional............................................. 114

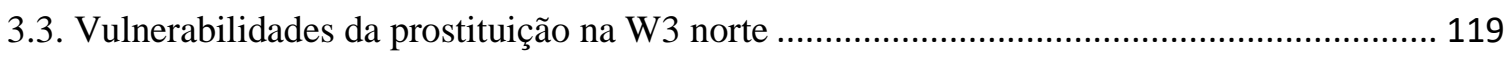

4. Notas para um dispositivo identitário da prostituição na W3 norte ........................................... 122

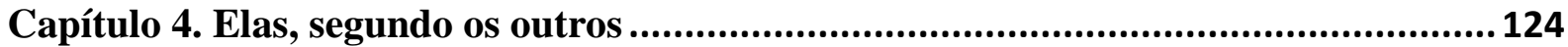

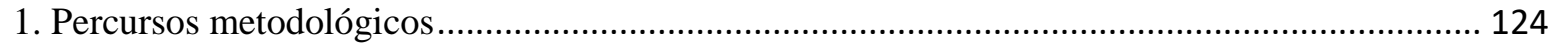

2. O mercado de prostituição na W3 norte............................................................................... 126

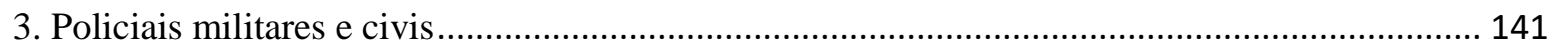

4. Notas para um dispositivo da prostituição feminina na W3 norte a partir da percepção de clientes

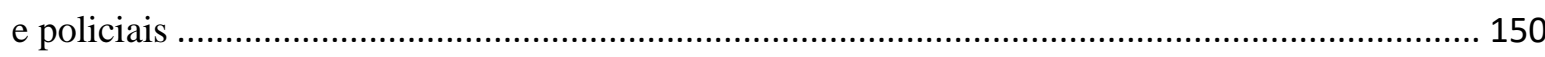


Capítulo 5. Elas, na versão da Academia ............................................................152

1. Conhecimento, representação social, campo científico e campo intelectual feminista................ 152

2. (Dis)putas no campo intelectual feminista pelo significado da prostituição ................................ 160

3. Mas é no "campo de batalha" que têm voz as putas da W3 norte............................................. 168

4. Notas para um dispositivo acadêmico da prostituição na W3 norte............................................ 173

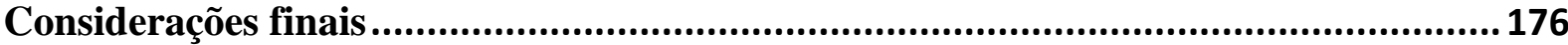

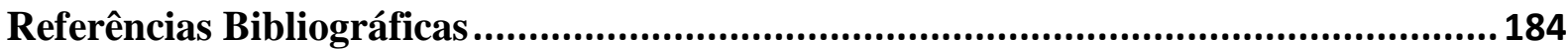

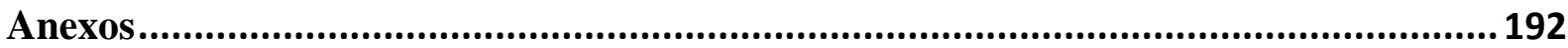

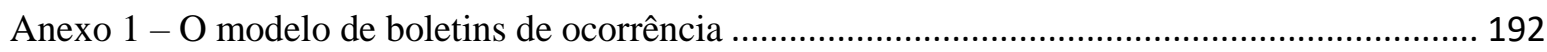

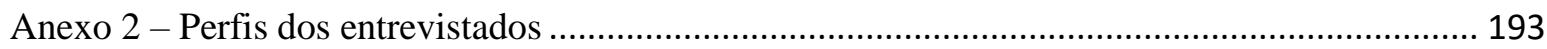

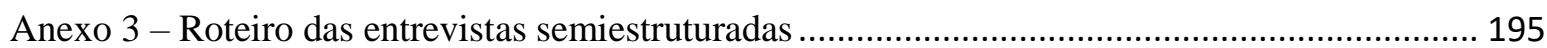

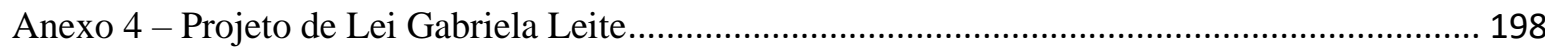




\section{Introdução densa}

Não existem verdades, existem versões.

Talvez seja esse o maior aprendizado desse trabalho, que tem como objeto as nuances da prostituição de rua em uma das avenidas mais importantes da Capital Federal: a W3 norte. Em um primeiro momento, pela minha condição profissional de delegada de polícia da Polícia Civil do Distrito Federal, lotada na $2^{\mathrm{a}}$ Delegacia de Polícia ${ }^{1}$, responsável pela área da avenida W3 norte, a curiosidade pelo tema da prostituição veio por meio de uma dessas nuances: a criminalidade urbana. Em diversos plantões policiais, tive a oportunidade de lidar com vários tipos de crimes relacionados à prostituição, não necessariamente aqueles ligados à sua exploração ${ }^{2}$, mas uma criminalidade urbana específica que acontecia em torno da prostituição como crimes de tráfico e uso de entorpecentes, contra a integridade física (lesões corporais, vias de fato), contra a vida (homicídio ${ }^{3}$ ), contra o patrimônio (furto, roubo e latrocínio). Nessas situações, percebia que as prostitutas ocupavam diversos papéis: eram autoras, testemunhas e vítimas. Da minha "óptica" ou "versão" como policial, do balcão da delegacia, e tendo em conta apenas os casos a mim apresentados e todo o repertório das representações sociais e históricas mais comuns relacionados ao tema da prostituição, indaguei-me: "Seria o ambiente profissional de "putas" e de "michês" criminógeno?".

De fato, essa pergunta é bem provocativa e traz uma carga que ilustra complexidades teóricas e empíricas que extrapolam, em muito, o próprio tom pejorativo que as palavras "putas" e "michês" assumem no âmbito das representações sociais, jurídicas e institucionais que, tradicionalmente, a associam a uma ideia de "vida fácil", com um tipo de comportamento que "não compensa" (e que, por isso, deve ser reprimido). Não raro se verificam discursos que estabelecem relações (amiúde, necessárias e diretas) entre a prostituição e o mundo do crime no espaço urbano. Trata-se de representações sociais bastante frequentes no discurso do “senso comum teórico dos juristas" (WARAT, 1982), principalmente, quando se considera o ambiente marginalizado e obscuro em que a atividade de prostituição é realizada.

\footnotetext{
${ }^{1}$ Além de pesquisadora, sou delegada de polícia, na Polícia Civil do Distrito Federal, já há 6 anos, atuando nos plantões policias de delegacias de polícia da área central de Brasília, ou seja, "bairros" ou regiões administrativas da Asa Sul, Asa Norte, Área Central, Granja do Torto, Sudoeste, Cruzeiro, Lago Sul e Lago Norte, áreas de concentração da maior renda per capita do Distrito Federal.

${ }^{2}$ Apesar de a atividade de prostituição em si não ser proibida pelo ordenamento jurídico, seu favorecimento ou a exploração sexual, na qual se considera qualquer vitimização do indivíduo voltada a tirar proveito, abusar, lucrar mediante fraude ou engodo de pessoas, é extremamente reprimido, sendo consideradas crimes as condutas de favorecimento da prostituição ou outra forma de exploração de menor, casa de prostituição, rufianismo, tráfico de pessoas para fins de exploração sexual (Art. 218-B, Art. 228, Art. 229, Art. 230 e Art. 231, todos do Código Penal).

${ }^{3}$ No período considerado no presente trabalho, não havia ainda o crime específico de feminicídio, o que aconteceu apenas com a edição da Lei 13.104/16.
} 
Juridicamente, prostituição é a atividade sexual realizada por um indivíduo, maior de 18 anos e capaz, de forma habitual, com número indistinto de parceiros, mediante pagamento em valores monetários ou outros bens. O sexo na vida do indivíduo é atividade profissional e não simplesmente prazer (NUCCI, 2009). Ainda em nível legal, a atividade de prostituição em si não é proibida, a qualquer título, pelo ordenamento jurídico brasileiro, muito menos considerada como crime.

Ao mesmo tempo, a prostituição é considerada um desvio das condutas padronizadas, e é estigmatizada no meio social (GOFFMAN, 1988, e BECKER, 2008), onde seu exercício como atividade profissional não é estritamente regulado, de modo que esses profissionais vivem à margem da sociedade e do mercado de trabalho formal.

Por viverem a margem da sociedade, o próprio ambiente urbano destinado à prostituição de rua é menos valorizado, desprovido de maiores equipamentos urbanos, e, no imaginário social, é tido como abjeto e escuro.

Nesse contexto, seria possível pensar no surgimento, nesse espaço segregado, de um ambiente com regras próprias, uma subcultura clandestina favorável à ocorrência de diversos tipos de crimes inseridos no contexto urbano? Tal situação traria prejuízos tanto para os "profissionais do sexo" ou prostitutas ${ }^{4}$ quanto para toda a vizinhança onde é desenvolvida tal atividade?

Em razão da existência desse ambiente peculiar e pela sua conduta social, tida, muitas vezes, como desviante, uma parte significativa dessas prostitutas são tratadas, pelas agências do Sistema de Justiça Penal, como "criminosas/criminosos", sem sequer terem cometido qualquer conduta tipificada pelo Direito como uma infração penal. Nesse momento, as noções de "marginalidade" social e jurídica se aproximam de maneira preocupante e podem comprometer os direitos de cidadania e a própria dignidade das envolvidas.

Crime e prostituição são objetos de estudo relacionados aos "desvios de condutas" e são assim tratados pelo Direito, pela polícia e pela Sociologia. Ademais, suas relações e interações no ambiente urbano realçam ainda mais essa abordagem "desviante". Todavia, ainda que, por hipótese, se considere imediata a associação entre a atividade de prostituição e certos tipos de crime, principalmente no contexto de grandes centros urbanos, é curioso observar que não há estudos empíricos ou sequer evidências de como essas relações realmente se dariam: se, de fato, a prostituição é, ou não, ingrediente da dinâmica do crime no local onde

\footnotetext{
${ }^{4}$ A atividade de prostituição é realizada independente do sexo ou gênero, mas na grande maioria das vezes e das observações, verifica-se que ela é prestada por prostitutas do gênero feminino, termo que será utilizado ao longo do texto. Contudo, essa questão será melhor problematizada no item referente a narrativas sobre a prostituição, bem como no capítulo 5, "Elas, as prostitutas".
} 
ela se desenvolveria, se as prostitutas figurariam mais como autoras de delitos, vítimas ou testemunhas e de que forma e quais seriam suas relações com o ambiente urbano em que estão inseridas. Porém, tal deficiência de informação não apresenta empecilho para que o tema seja investigado. Pelo contrário, reforça ainda mais a importância da exploração do problema para compreender sua dinâmica e estruturas sociais, institucionais e jurídicas ${ }^{5}$, capazes de desvelar as características dessa eventual associação.

A partir daí, iniciei a pesquisa com o enfoque preliminar na relação entre a prostituição e os crimes a ela associados no contexto urbano, no caso, na avenida W3 norte, de Brasília.

Contudo, durante a realização desta investigação ${ }^{6}$, pude perceber que, para além das corriqueiras representações sociais que relacionam prostituição e criminalidade, essas prostitutas praticam muitas outras atividades, que se inter-relacionam a diversos mundos, com outras "versões" de suas vidas: o programa, a rua, a família, a polícia, o crime e a "vida real"7.

Essa riqueza de vivências, composta de constantes "ultra"passagens entre todos esses "versos", foi capaz de me tocar, e comecei a observar a realidade não apenas com supostos "olhos cegos" lex, sed lex ${ }^{9}$, mas também a observar a ambiguidade nas relações entre prostituição, a criminalidade e a cidade. Assim, a "versão" jurídica do balcão da delegacia não era mais suficiente.

Com essa inserção no mundo sociológico, com muitas leituras e várias lentes diferentes das quais estava acostumada a utilizar, percebi que eu mesma também estava em um dilema similar àquele das profissionais da prostituição: constantes ultrapassagens entre mundos, no

\footnotetext{
${ }^{5}$ Pretende-se também estabelecer um diálogo entre a atividade de prostituição com o Direito Penal, objetivando a melhor compreensão de seu exercício no espaço urbano e de suas relações com os mais diversos atores sociais, entre os quais estariam também os personagens da criminalidade urbana. Sublinhe-se que a atividade de prostituição não é prevista como um crime ou uma contravenção penal, inclusive em respeito ao princípio da lesividade que rege o Direito Penal. Em síntese, segundo esse postulado, só pode ser considerada crime aquela conduta que lesione direitos de outras pessoas e que não é simplesmente um comportamento imoral, reprovável socialmente ou "pecaminoso". Há, basicamente, quatro funções para o princípio da lesividade: 1) proibir a incriminação de uma atitude interna, ideias ou convicções; 2) proibir a incriminação de simples estados ou condições existenciais; 3) proibir a incriminação de uma conduta que não exceda o âmbito do próprio autor e 4) proibir a incriminação de condutas desviadas que não afetem qualquer bem jurídico. (BATISTA, 1990)

${ }^{6}$ No ano de 2013, motivei-me a estudar melhor essa possível relação, tentando, inicialmente, relacionar os locais e espécies de crimes por meio de ocorrências policiais, por um lado, com a atividade de prostituição, de outro, o que se tornou um trabalho final de curso de uma pós-graduação em Análise Criminal, pela Universidade Católica de Brasília. O interesse pela pesquisa intensificou-se com mais questionamentos e observações, culminando com o ingresso no Mestrado em Sociologia na Universidade de Brasília.

${ }^{7}$ Atividades muito diferentes das outras que envolvem a fantasia de poder ser personagens diferentes ao assumir outros nomes em programas, o sigilo perante os clientes, o risco de violência ao frequentarem as "penumbras urbanas" e lidarem com desconhecidos, a relação com os policiais militares em suas várias abordagens pessoais, a competição pelo espaço de trabalho e a volta "à vida real”, nas quais muitas delas são chefes de família, responsáveis pela educação de seus filhos.

${ }^{8}$ Uma forte representação social no Ocidente como o símbolo da Justiça é Themis, a deusa grega da justiça que é representada com uma espada e uma venda nos olhos, que alude à imposição da Justiça a quem quer que seja.

9 A lei é dura, mas é a lei.
} 
meu caso, o direito, a polícia e a sociologia ${ }^{10}$. Dilemas que interseccionam "objeto de investigação" e "pesquisadora" em um cenário caracterizado pela intensificação dos estímulos nervosos, a cidade, nas palavras de Simmel $^{11}$, e que colocam o desafio do constante exercício de reflexão sobre a relação entre sujeito e objeto.

Pretendi, dessa forma, com a presente investigação, identificar as várias versões da prostituição de rua na avenida W3 norte de Brasília, tendo em conta três aspectos principais: o exercício da atividade de prostituição, a apropriação da prostituição no espaço urbano e a relação entre a prostituição, vulnerabilidade e criminalidade.

Para abordar essas questões, além da intensa revisão bibliográfica, foram realizadas observações do espaço urbano na avenida W3 norte em diferentes dias e horários, e recuperadas notícias de jornal sobre a prostituição no contexto indicado.

Buscando a "força dos números"12, analisei as ocorrências policiais entre os anos de 2010 a 2015, que de alguma forma, fizessem referência à prostituição e à criminalidade, de maneira a localizar no espaço e no tempo suas incidências e frequência ao longo da avenida W3 norte. Realizei também entrevistas com os policiais civis responsáveis por registrar essas ocorrências policiais, buscando entender a forma pela qual se dão esses registros quando relacionados à atividade de prostituição.

Além da análise do espaço e dos "números" a ele relacionados, foram realizadas entrevistas com prostitutas da avenida W3 norte, com clientes do serviço, um publicitário da atividade de prostituição, e com policiais militares e policiais civis responsáveis pela segurança da área ${ }^{13}$, cujos perfis estão descritos no Anexo 2 do presente trabalho.

\footnotetext{
${ }^{10}$ O que eu chamo de "mundo jurídico" não é o mesmo que o "mundo policial". Extraio essa conclusão depois de 11 anos formada como bacharela em Direito, de ter trabalhado 7 anos no Tribunal de Justiça do Distrito Federal e dos Territórios e já há mais de 5 anos na Polícia Civil do Distrito Federal. Apesar de o cargo de delegado de polícia exigir bacharelado em Direito para seu ocupante, a Polícia, enquanto instituição, apresenta uma cultura totalmente distinta daquela do cotidiano formal dos Tribunais. No ambiente policial, há mais informalidade, ambiguidade, oralidade e maior liberdade e criatividade na administração dos conflitos, características que conferem uma modelagem do exercício da atividade jurídica bem diferente entre o Poder Judiciário/Ministério Público/Defensoria Pública (sujeitos na ação penal) e a Polícia. Nesse sentido, KANT DE LIMA, trata de narrativas sobre a posição do delegado de polícia como uma ligação ou um tradutor desses dois mundos, o jurídico e o polícia. (KANT DE LIMA, 1997)

11 É exatamente na cidade, onde as relações subjetivas se tornam objetivas pela intensidade de estímulos externos e internos e pela cultura impessoal promovida pelas trocas monetárias, que foi possível desenvolver/intensificar a atividade de prostituição como uma mercadoria, com valor monetário, um serviço à disposição de indeterminadas pessoas. "Na esfera da psicologia econômica do pequeno grupo, é importante que, sob condições primitivas, a produção sirva ao cliente que solicita a mercadoria, de modo que o produtor e o consumidor se conheçam. A metrópole moderna, entretanto, é provida quase que inteiramente pela produção para o mercador, isto é, para compradores inteiramente desconhecidos, que nunca entram pessoalmente no campo de visão propriamente dito do produtor" (SIMMEL, 2005).

12 Por "força dos números", refiro-me à representação social da valorização da métrica e da mensuração na produção do conhecimento científico, como se apenas os números ou a busca incansável por padrões seria imprescindível para a compreensão da realidade, ideia bastante relacionada inclusive com o surgimento da Sociologia como área autônoma do conhecimento, como a "física social". Não que os "números" não tenham sua importância, mas é preciso considerar outros elementos, principalmente e inclusive sua própria produção e análise.

${ }^{13}$ Ao total, foram feitas entrevistas a 10 prostitutas que atuam na avenida W3 Norte, 4 clientes, 3 policiais civis responsáveis pelo registro de ocorrências nas $5^{\mathrm{a}}$ e $2^{\mathrm{a}}$ Delegacias de Polícia da Polícia Civil do Distrito Federal - DP/PCDF, 2 delegadas da
} 
Todavia, a vigilância epistemológica do sociólogo (BOURDIEU, 1983) e o cuidado metodológico na produção do conhecimento científico (BACHELAR, 1996), levaram-me a enfrentar a questão de como uma policial poderia estudar a prostituição de rua e suas relações com a criminalidade na sua própria área de atuação? Cuidava-se de uma questão desafiadora tanto como pesquisadora, como profissional, e como mulher.

Diante dessa dificuldade inicial, busquei leituras capazes de me ajudar a superar esse "pretenso dilema" e verifiquei uma enorme quantidade de etnografias realizadas por nativos: professores que estudam o cotidiano de suas escolas, policiais militares que estudam suas instituições, juízes que estudam seus próprios tribunais, ativistas que estudam seus próprios movimentos políticos e sociais $^{14}$. Assim, pude observar que, como qualquer outro pesquisador, teria vantagens e desvantagens no estudo em razão da minha condição.

Por um lado, minha condição de policial mostrou-se uma condição diferenciada, o que, junto a meu repertório jurídico, garantiu-me vantagens importantes: acesso imediato e irrestrito aos boletins de ocorrência, bem como à sua interpretação jurídica, e muita facilidade em conseguir entrevistas tanto com policiais civis quanto com policiais militares.

Por outro lado, também, por trabalhar como policial, tive dois problemas básicos a serem enfrentados. O primeiro foi admitir que "uma vez policial, sempre serei policial". A internalização de uma postura de "sempre alerta ${ }^{15}$ " da atividade policial e de um regime de verdade centrada na ideia de verdade real ${ }^{16}$, ou seja, o habitus ${ }^{17}$ do ser policial tem uma força inegável. Por vezes, no início das observações do espaço e de algumas entrevistas, eu me via

Delegacia de Atendimento a Mulher - DEAM, 2 agentes de investigação da $2^{\mathrm{a}}$ DP/PCDF e 5 policiais militares que atuam no policiamento ordinário e no policiamento operacional (GTOP) na área da W3 norte.

${ }^{14}$ Apenas a título de exemplo, cito os trabalhos de Robson Rodrigues da Silva, dissertação de mestrado pela Universidade Federal Fluminense, intitulada "Entre a caserna e a rua: o dilema do "pato"”, 2009; Marcos Santana, dissertação de doutorado pela Universidade de Campinas, "Sou policial, mas sou mulher: Gênero e Representações sociais na Polícia Militar de São Paulo, 2015; Gilvan Gomes Silva, dissertação de mestrado pela Universidade de Brasília, "A lógica da Polícia Militar do Distrito Federal na construção do elemento suspeito", 2009; Gilvan Gomes Silva, tese de doutorado pela Universidade de Brasília, "Políticas de Segurança Pública - um olhar sobre a formação da agenda, da mudança do padrão do policiamento e manutenção do Policiamento Comunitário no Distrito Federal, 2015."

${ }^{15}$ O hino da Polícia Civil do Distrito Federal, a propósito, cantando em todas as cerimônias oficiais da instituição ressalta essa atitude da internalização da doxa da atividade policial, traduzido no habitus do "sempre alerta": "Em defesa da paz social/do direito da ordem da lei/Sempre, sempre eu serei policial/Atalaia eterno eu serei". Atalaia tem sentido denotativo de montanha e conotativo de sentinela.

${ }^{16}$ A verdade real, ou princípio da verdade real, é um conceito desenvolvido no contexto do Direito Processual Penal, e reflete a ideia de que a verdade dos fatos está efetivamente ao alcance do juiz (JÚNIOR, 2012, p. 815). A ela se contrapõe a chamada verdade processual, que seria a verdade alcançada pela observância estrita das regras processuais (JÚNIOR, 2012, p. 817). Para os críticos da ideia de verdade real no Direito Processual Penal, essa distinção é importante, porque a referência a uma verdade real permitiria, em tese, um cálculo utilitarista, em que as normas processuais seriam flexibilizadas em prol desse valor externo ao processo: a verdade real ou histórica. Por outro lado, como a verdade processual é produzida dentro do próprio processo, a referência a esta não poderia ser utilizada para flexibilizar normas e garantias processuais, o que, para esses críticos, é um arranjo mais condizente com o Estado de Direito (JÚNIOR, 2012, p. 815-820).

${ }^{17} \mathrm{O}$ espaço de posições sociais se retraduz em um espaço de tomadas de posição pela intermediação do espaço de disposições (ou do habitus); ou, em outros termos, ao sistema de separações diferenciais, que definem as diferentes posições nos dois sistemas principais do espaço social, corresponde um sistema de separações diferenciais nas propriedades dos agentes (ou de classes construídas como agentes), isto é, em suas políticas e nos bens que possuem (BORDIEU, 2008, p. 21). 
não como uma pesquisadora, mas como uma policial, sempre desconfiando dos movimentos, das palavras utilizadas. O segundo foi o dilema de me identificar, ou não, como delegada de polícia no início das entrevistas sem qualquer demanda do(a) entrevistado(a) nesse sentido. Eu temia "impor" certa autoridade ao (à) entrevistado(a) que pudesse prejudicar a fluidez da entrevista, que, aos olhos do(a) entrevistado(a), poderia ser interpretado como um interrogatório policial.

Para enfrentar meus desafios de pesquisa, desenvolvi algumas estratégias. Assim, como fez Robson Silva ${ }^{18}$, "foi-me necessário também um exercício extra de estranhamento, ainda mais disciplinado que o da praxe etnográfica". Com essa representação constante do meu “habitus", procurei, a todo tempo me policiar.

Devo salientar que, durante o período da pesquisa, estive lotada em uma Central de Flagrantes, na $5^{\text {a }}$ Delegacia de Polícia, localizada na região central de Brasília. Assim, devido ao acúmulo de trabalho, quase nunca eu saia para fazer diligências externas, de modo que minha identidade como policial ficou bastante preservada e, durante as entrevistas na Avenida W3 norte, eu não fui reconhecida pelas minhas interlocutoras como policial. Sempre me apresentei como estudante do mestrado da sociologia da UnB e não tive problemas com isso.

Além dessa vigilância epistemológica permanente, procurei me distanciar por um período da minha atividade profissional. Durante três meses gozei licença capacitação tanto para dedicar-me exclusivamente à pesquisa, quanto para realizar o que chamei de um "período depurativo", no qual suspendi contatos diretos com a atividade policial e também com os grupos sociais de policiais. Esse distanciamento foi fundamental tanto para organizar minhas ideias e proporcionar uma desnaturalização dos assuntos da polícia e das minhas rotinas cognitivas.

Durante o período da licença, pude me dedicar, com maior tranquilidade, à realização das entrevistas com prostitutas da avenida W3, mesmo porque a atividade de prostituição de rua é realizada durante o período noturno, alcançando a madrugada.

Quanto aos entrevistados policiais (militares e civis do Distrito Federal), minha condição de policial foi, de fato, um facilitador, tanto para conseguir as entrevistas como também para uma abertura mais confortável para conversar sobre a pesquisa.

\footnotetext{
${ }^{18}$ Entre a caserna e a rua: o dilema do "pato". Uma análise antropológica da instituição policial militar a partir da Academia de Polícia Militar Dom João VI. Muitos dados que a princípio me pareciam óbvios se transformavam em verdadeiras armadilhas "naturais" para o nativo, exigindo do pesquisador um rigor ainda maior. Se por um lado as portas e atalhos da instituição estavam abertos para o nativo, os caminhos do "campo", por vezes, ofereciam essas armadilhas para o pesquisador. Talvez eu não tenha conseguido escapar de todas, mas com certeza me desvencilhei de muitas, tal qual os cautelosos Ndembu da antiga Rodésia do Norte que deixavam "marcas de caçador" nas cascas das árvores para terem como voltar das perigosas florestas de sua tribo (TURNER, 2005).
} 
Não posso desconsiderar também minha condição de mulher-pesquisadora, a qual me ajudou a ter uma abertura maior com as entrevistadas prostitutas, pois elas pareciam se sentir mais à vontade compartilhando suas ideias, versões e opiniões com uma mulher.

Contudo, mesmo com todo esse cuidado e "policiamento metodológico", já curvo, humildemente, às falhas que não consegui identificar ao longo do trabalho. Ao final da pesquisa, posso dizer que não apenas obtive ganhos acadêmicos em maturidade e conhecimento, mas também profissionais e pessoais. Os mundos da polícia, do direito e da sociologia imbricaram-se ainda mais para mim e pude apreender que de fato, "não existem verdades, mas versões".

\section{Metodologia e Dispositivo}

Prostituição de rua, criminalidade urbana a ela associada, suas relações, margens, limites e "ultra"passagens pelos mundos do direito, polícia e sociologia. Uma temática tão rica demanda metodologias capazes de captar descritivamente, o máximo possível, a densidade dessas relações.

Assim, busquei em Foucault ${ }^{19}$ o conceito de dispositivo como principal chave de leitura do presente trabalho, um elemento plástico e agregador, um cimento, capaz de alinhavar todas as relações e conclusões obtidas a partir da análise dos dados colhidos.

O termo dispositivo ${ }^{20}$ foi adotado por Foucault em uma fase mais madura de suas obras para possibilitar uma introdução à análise do poder, visto não apenas como um aspecto objetivo, formal, ou seja, um "conjunto de instituições e aparelhos garantidores da sujeição dos cidadãos em um Estado determinado", ou como um "modo de sujeição que, por oposição à violência, tenha a forma de regra", que são tão somente suas "formas terminais", mas, sobretudo, o poder como "a multiplicidade de correlações de força imanentes ao domínio onde se exercem e constitutivas de sua organização; o jogo que, através de lutas e afrontamentos incessantes as transforma, reforça, inverte; os apoios que tais correlações de força encontram uma nas outras, formando cadeias ou sistemas ou ao contrário, as defasagens e contradições que as isolam entre si; enfim, as estratégias em que se originam e cujo esboço

\footnotetext{
${ }^{19}$ Michel Foucault (1926-1984) foi um filósofo, historiador das ideias, filólogo, crítico literário e um grande sociólogo contemporâneo francês. Seus principais estudos ressaltam a relação entre poder e conhecimento e como eles são utilizados como forma de controle por meio de instituições sociais, tanto físicas, como prisões, escolas, hospitais e manicômios, como abstratas, família, casamento, linguagem.

${ }^{20} \mathrm{O}$ termo original utilizado por Foucault é dispositif e sua tradução é bem variada na literatura, causando inúmeras discussões acadêmicas, as quais ultrapassam os objetivos desse trabalho. Contudo, para os presentes fins, necessário o conhecimento de que dispositivo pode ser considerado também como apparatus, aparelho, ou construto. Para saber mais: BUSSOLINI, Jeffrey. What is a Dispositive? in: Foucault studies, n. 10, pp. 85-107, November 2010.
} 
geral ou cristalização institucional toma corpo nos aparelhos estatais, na formulação da lei, nas hegemonias sociais". (FOUCAULT, 1998, p. 88-89).

As obras de Foucault tiveram períodos distintos: a arqueologia, fase inicial, na qual se dedicou ao estudo do que chamou de episteme $^{21}$; e genealogia, fase posterior, na qual desenvolveu o conceito de dispositivo.

$\mathrm{Na}$ fase da arqueologia, ele se propôs a analisar os conhecimentos desnudos, ou seja, sem se referir a seu valor racional ou sua objetividade. Nas próprias palavras do autor, "a arqueologia busca definir não os pensamentos, as representações, as imagens, os temas, as obsessões que se ocultam ou se manifestam nos discursos, mas os próprios discursos, enquanto práticas que obedecem a regras. (...) a arqueologia não procura reconstituir o que pôde ser pensado, desejado, visado, experimentado, almejado pelos próprios homens no próprio instante que proferiram o discurso.” (FOUCAULT, 2005B).

Já a genealogia seria a ampliação do campo de investigação da episteme para incluir o estudo das práticas não discursivas, discursos "ocultos", a partir do desenvolvimento do conceito de dispositivo, cujo conceito foi dado pelo próprio autor em uma entrevista:

isso que eu tento identificar sob este nome (isto é, dispositivo) é (...) primeiramente, um conjunto de elementos heterogêneos, composto por discursos, por instituições, por arranjos de arquitetura, por decisões regulamentares, por leis, por medidas administrativas, por enunciados científicos, por proposições filosóficas, morais, filantrópicas, enfim: daquilo que é dito bem como do que não é dito, são os elementos do dispositivo. O dispositivo, por si só, é o resultado que se pode estabelecer entre estes elementos. (apud Raffnsøe, 2008).

A partir desse conceito, bem como de outras obras de Foucault e de seus comentaristas, é possível identificar cinco perspectivas que tentam apreender a ideia de dispositivo: 1) uma trança ou um emaranhado de elementos heterogêneos relacionando entre si em torno de um tema (DELEUZE, 1992); 2) a determinação da natureza do nexo que pode existir entre esses elementos heterogêneos (CASTRO, 2009, e RAFFNSØE, 2008); 3) uma função estratégica, decorrente, na sua gênese, da necessidade de responder a uma urgência (CASTRO, 2009); 4) sua definição por meio de sua própria criação estratégica e sua autorreprodução; 5) sua função de verificação, ao constituir uma orientação de comportamento e controle, ao mesmo tempo em que há um "processo de perpétuo preenchimento estratégico" (CASTRO, 2009).

\footnotetext{
${ }^{21}$ Episteme é a palavra grega para conhecimento e epistemologia seria o estudo do conhecimento. Para Foucault, a ideia de episteme é mais específica de forma a ser localizada no espaço e no tempo e como ele mesmo diz: "é o conjunto das relações que podem unir, em uma dada época, as práticas discursivas que dão lugar a figuras epistemológicas, a ciências, eventualmente a sistemas formalizados; (...) é o conjunto de relações que podem ser descobertas, para uma época dada, entre as ciências, quando estas são analisadas no nível das regularidades discursivas) (FOUCAULT, 2005. p. 214).
} 
Quanto ao primeiro elemento, uma rede de relações heterogêneas, ou a um emaranhado de elementos objetivos e subjetivos, de diferentes naturezas, em torno de um determinado tema, Deleuze (1992) destaca que o dispositivo é composto por linhas de visibilidade e de enunciação, linhas de invisibilidade de força e de subjetivação e linhas de rupturas, todas se entrecruzando, misturando-se simultaneamente e influenciando-se. A partir dessa ideia, ele identifica duas outras características do dispositivo: a) o repúdio à universalidade, uma vez que ele é dinâmico, dependendo do caso concreto para sua delimitação ("working of ground”); b) sua potencialidade autoreprodutiva e criativa, resultado da interação dessa rede relacional heterogênea.

A natureza específica de cada dispositivo vem do resultado desse emaranhado de relações. O dispositivo não é a interpretação isolada desses elementos em rede, mas é a sua própria interação. Por exemplo, ao analisar o "dispositivo de poder”, Michel Foucault não se concentra apenas na interpretação de ações do titular do poder, da sua forma de manifestação específica ou dos sujeitos submissos a essa manifestação de poder, mas no exame da interação simultânea de todos esses fatores, que se condicionam e se determinam entre si, do que resulta um produto final, ao qual nomeou de dispositivo (RAFFNSØE, 2008).

Finalmente, a função estratégica do dispositivo reverte-se ao mesmo tempo em sua função de controle e em seu aspecto criativo e autorreprodutivo. $\mathrm{O}$ aspecto criativo vem da necessidade de se responder a uma urgência ou a uma situação social. Por exemplo, “a reabsorção de uma massa de população flutuante que era excessiva para uma economia mercantilista. Tal imperativo estratégico serviu como a matriz de um dispositivo que se converteu pouco a pouco no controle-sujeição da loucura, da doença mental, da neurose" (CASTRO, 2009).

Em um segundo momento, já criado o dispositivo, ele se delimita com outros elementos de influência e também exerce uma função de disciplina sobre os sujeitos. Dessa forma, cada efeito positivo e negativo, desejado ou não, entra em ressonância ou em contradição com outros e exige reajuste, sempre considerando, no preenchimento de seu sentido, o(s) objetivo(s) estratégico(s). Assim, o dispositivo teria uma "face de Janus",22, pois, ao mesmo tempo em que possui uma dimensão criativa, se modificando pelas forças de seus próprios

\footnotetext{
${ }^{22}$ Janus, na mitologia romana, é o deus das portas, sendo representado com duas faces, uma virada para o passado e outra para o futuro. A origem do nome do primeiro mês do ano, Janeiro, remete ao deus Janus.
} 
elementos constitutivos, ele também influencia o comportamento e orienta a ação das forças emaranhadas na rede que o delimita. (BUSSOLINI, 2010) ${ }^{23}$

O conceito de dispositivo é fundamental para a constituição de um saber genealógico para Foucault. Em sua obra "A ordem do discurso", ao ressaltar a importância do discurso principalmente nas áreas da sexualidade e da política, o autor defende a existência de três regras metodológicas baseadas no conceito de dispositivo, a saber, o princípio de descontinuidade, de especificidade e o de exterioridade.

O princípio de descontinuidade trata os discursos como práticas descontínuas, sem supor que sob os discursos efetivamente pronunciados existe outro discurso ilimitado, silencioso e contínuo, que é reprimido e censurado.

Já o princípio de especificidade trata de considerar os discursos como uma violência que fazemos às coisas, na qual não há significações prévias, uma prática que lhes impomos em todo o caso e é nessa prática que os acontecimentos do discurso encontram o princípio de sua regularidade.

Por fim, o princípio de exterioridade indica o não fechamento da análise no próprio discurso, mas em suas condições externas de possibilidade e relação com os elementos de sua fronteira, uma série aleatória de acontecimentos diversos (FOUCAULT, 2005A, p. 52-53).

Os princípios mencionados guardam comunhão com os elementos da ideia de dispositivo, apresentados acima, ressaltando a importância da interação dos elementos que o constituem para sua própria definição, sua função estratégica e a captação do expresso e do implícito.

A ideia de dispositivo, portanto, é um poderoso aparato para o estudo de categorias, ao incluir elementos de várias naturezas, normativos, subjetivos, objetivos, temporais, espaciais, discursivos e não discursivos, todos emaranhados entre si, em uma teia de relações, determinando-se e influenciando-se em torno de uma função estratégica.

Essa possibilidade de uma constante articulação entre vários elementos que formam uma rede, um emaranhado de forças que se autoinfluenciam, de forma dinâmica, criativa e autoreprodutiva confere uma plasticidade ao conceito de dispositivo que é ideal para trabalhar os vários elementos capazes de desvelar as relações entre a prostituição ${ }^{24}$ e a criminalidade a ela associada.

\footnotetext{
23 "The dispositive has a Janus-faced strategic functions as network of power relations allowing a certain confluence and direction of forces, or as conceptual tool allowing at least a provisional analysis of a certain configuration of entities, knowledges, and discourses that discloses points of existing and possible resistance" (BUSSOLINI, 2010).

${ }^{24}$ Foucault, na obra "A história da sexualidade", trata de um dispositivo da sexualidade, o qual aponta, em resumo, os seguintes elementos: 1) operabilidade por meio de técnicas móveis, poliformas e conjunturais de poder; 2) promove formas de controle e comportamento social; 3) refere-se às sensações do corpo, à qualidade dos prazeres, à natureza das impressões;
} 
Em síntese, têm-se como características da ideia em torno de dispositivo: 1) trata-se de uma rede de relações heterogêneas, com elementos objetivos e subjetivos a serem analisados; 2) o dispositivo é o resultante de todas as forças atuantes, ou melhor, é própria interação entre elas; 3) o dispositivo tem funções estratégicas e de controle, manifestadas em sua capacidade confirmativa, ou seja, de reforçar comportamentos esperados, e em sua capacidade criativa, ao inovar em condutas; 4) a ideia de dispositivo remete à descontinuidade, a conceitos e significantes fluídos, específicos e localizados no espaço e tempo, e sempre aberto para a influência de elementos externos.

Dessa forma, o presente estudo sobre a atividade de prostituição levará em conta a ideia de dispositivo, pois é um fenômeno complexo, com muitas variantes, elementos e forças que se autoinfluenciam, envoltos também em uma estratégia de saber e de poder.

A análise da prostituição de rua na avenida W3 norte será feita tendo como base três aspectos ou temas principais: a atividade de prostituição; o espaço urbano onde ela se desenvolve; e a criminalidade a elas associadas, os quais serão abordados sob a perspectiva do dispositivo elaborada por Foucault. Esses três aspectos devem, assim, ser analisados em conjunto, pois a sua interação compõe o dispositivo de "prostituição de rua na avenida W3 norte".

A partir desses três objetos - prostituição, cidade e criminalidade a elas associadas pretende-se analisar, basicamente, elementos objetivos e subjetivos desse fenômeno. Na vertente objetiva, situa-se o estudo da composição simbólica e espacial na avenida W3 norte: análise de projeto de elaboração urbanística do local; estudo da apropriação do espaço pelas prostitutas, observando-o em diferentes dias da semana e horários e localização espacial da criminalidade urbana associada à atividade de prostituição, por meio de análise de ocorrências policiais. Na vertente subjetiva, buscam-se encontrar, nas narrativas dos sujeitos envolvidos na atividade de prostituição na avenida W3 norte, as representações sociais desses atores sobre prostituição de rua e a criminalidade que eles associam à prostituição. Ressalta-se, contudo, que, tendo em conta a ideia de dispositivo, essa separação entre elementos objetivos e subjetivos justificou-se apenas para facilitar o estudo, uma vez que todos esses aspectos se autodeterminam, pois o dispositivo é exatamente o resultado da interação.

4) ligação com a economia por meio da ideia do corpo. Dessa forma, para Foucault, o dispositivo da sexualidade tem como principal função estratégica a "penetração e o controle do corpo individual e social" (CASTRO, 2009). 


\section{Métodos de pesquisa}

Para examinar o aspecto "objetivo" 25 dos objetos do trabalho foram utilizadas basicamente quatro técnicas de pesquisa: a análise documental, a observação participante, a análise de conteúdo e a entrevista semiestruturada.

Como o espaço físico do estudo é avenida W3 norte, buscou-se recuperar a história da avenida W3 principalmente no contexto da própria história de Brasília, cidade planejada e tombada pelo Patrimônio Histórico Mundial. Além da análise desses documentos, a apropriação desse espaço urbano pela prostituição foi observada por meio de notícias de jornais e complementada pela observação da pesquisadora do local em diferentes dias da semana e horários.

A fim de entender eventuais relações entre a atividade de prostituição na avenida W3 norte e a criminalidade urbana, foram analisadas ocorrências policiais dos anos 2010-2015 que tivessem alguma relação com o local e também com a prostituição ${ }^{26}$.

Para tanto, adotou-se a técnica da análise de conteúdo que tem como ponto de partida o sentido da mensagem que é transmitido pelo texto, "sentido que não pode ser considerado um ato isolado, pois os diferentes modos pelos quais o sujeito se inscreve no texto correspondem a diferentes representações que tem de si mesmo como sujeito e do controle que tem dos processos discursivos textuais com que está lidando quando fala ou escreve" (FRANCO, 2008, p. 19). Tendo em vista a importância das representações sociais dos próprios subscritores das ocorrências policiais, foram realizadas entrevistas com esses policiais civis, a fim de melhor compreender seus processos cognitivos para a confecção de um boletim de ocorrência que envolva a atividade de prostituição na avenida W3 norte.

Quanto ao aspecto "subjetivo", referente à identificação das representações sociais ${ }^{27}$ dos atores sociais envolvidos na atividade de prostituição na avenida W3 norte, foram realizadas

\footnotetext{
${ }^{25}$ Conforme já ressaltei, a análise do espaço urbano e de sua apropriação pelos atores sociais não constitui em si, uma atividade objetiva, independente de qualquer valoração. A divisão em aspectos objetivos e subjetivos somente foi adotada para facilitar o estudo do problema.

${ }^{26}$ As estratégias de análise dos boletins de ocorrências serão melhor desenvolvidas no capítulo 2.

${ }^{27}$ O desenvolvimento do fenômeno das "representações sociais" (MOSCOVICI, 2007, p. 29) como aplicação metodológica nos estudos sociológicos deveu-se, em grande medida ao psicólogo social Serge Moscovici, o qual, a partir, principalmente, das ideias de Durkheim sobre a representação coletiva, enriqueceu a análise sociológica com a perspectiva psicológica, na medida em que os atores sociais influenciam e também são influenciados pela interpretação dos fatos sociais. Essa perspectiva foi fundamental para análise das entrevistas dos atores sociais relacionados à atividade de prostituição na avenida W3 norte e será mais bem examinada a seguir, em "Narrativas sobre a prostituição", bem como nos capítulos 4 e 5, onde será possível fazer o cotejo entre as narrativas das entrevistas e a própria "teoria das representações sociais". Esclarece-se que há outros métodos de estudo capazes de analisar o aspecto subjetivo das impressões dos atores sociais como, por exemplo, a análise do discurso. Contudo, tendo em vista a complexidade do método de análise do discurso, bem como suas inúmeras vertentes, optou-se pelo método das representações sociais que, igualmente, atende aos fins dessa pesquisa, sem que seja
} 
entrevistas semiestruturadas (COLOGNESE, 1998), nas quais há um roteiro prévio, mas podem surgir nossas questões e temas a depender da interação com o entrevistado. Os roteiros utilizados estão ao final do trabalho, no anexo 3.

\section{Narrativas sobre prostituição}

Mulheres da esquina, com roupas provocantes, unhas e cabelos feitos. Mulheres altivas, com personalidade. Mulheres que "rodam bolsinha". Putas. Mulheres sofridas, vítimas das circunstâncias da vida. Miseráveis. Mulheres indecentes. Mariposas da noite. Primas. Prostitutas. Mulheres públicas. Femmes Fatales. Mulheres-aranha. Sarjeta. Escória social. Garotas de programa. Trabalho sujo. Mulheres com o corpo do pecado. Mulheres difusoras de doenças sexuais. Mulheres da vida.

Mesmo quem nunca tenha tido contato direto com uma prostituta, essas são algumas das ideias recorrentes que vêm à mente quando se trata do tema. Claro que essas imagens podem ser marcadas por preconceitos, distantes daquelas que poderiam melhor representar a ideia de prostituição. Contudo, não há como negar a importância e força dessas pré-noções para estudar o tema, principalmente quando se tem a pretensão de construir o que seria um dispositivo para a prostituição ocorrida na avenida W3 norte.

Como se viu, esses pré-conceitos sobre um determinado assunto são chamados de "representações sociais", as quais, segundo Mannoni, são as bases da nossa vida psíquica, são peças essenciais da nossa epistemologia, por meio da qual temos acesso ao senso comum. Situadas na interface da psicologia e da sociologia, as representações sociais são enraizadas no coração do dispositivo social. Por vezes, objeto socialmente elaborado, outras são constitutivos de um objeto social, elas desenvolvem um papel determinante na vida mental dos seres humanos, cujos pensamentos, sentimentos, planos de ação, referenciais relacionais, estão nos valores emprestados em todas as coisas. Elas englobam efetivamente conceitos abstratos (a verdade, a fé, a beleza, a justiça), os objetos psíquicos (os cabelos, as árvores frutíferas), os objetos sociais (a cultura, a moda, as boas maneiras) e as categorias individuais (os professores, os estudantes, os médicos, os padeiros). Elas se interessam pelas operações predicativas e atributivas ou ainda os modos de ser. Mas elas também pontuam o discurso político e religioso, bem como todas as áreas do pensamento social: a ideologia, a mitologia, a demonologia, os contos, as lendas, as fábulas, o próprio conhecimento científico, bem como

necessário o enfrentamento das polêmicas daquele método, de modo que inclusive a palavra "discurso" foi evitada e substituída, em regra, pela palavra "narrativa". 
as áreas menos nobres como superstição, crenças e ilusões difundidas. Em suma, as representações sociais se apresentam como esquemas cognitivos elaborados e compartilhados por um grupo que permite a seus membros pensar, representar o mundo ao redor, orientar e organizar os comportamentos, frequentemente prescrevendo, normatizando ou proibindo objetos ou práticas (MANNONI, 2006, p. 2).

Pela sua natureza híbrida, tanto subjetiva quanto objetiva, a noção das representações sociais sempre permeou dois campos do conhecimento - a psicologia e a sociologia, de forma que, atualmente, ela é mais estudada pelo campo da psicologia-social. Contudo, a ideia das representações sociais foi um aperfeiçoamento do que Durkheim denominou, nas suas 'Regras do Método Sociológico' (2003, originalmente publicado, em francês, em 1895), como "representações coletivas" (MOSCOVICI, 1978, p. 25).

Durkheim, um dos fundadores da Sociologia, preocupou-se bastante com a delimitação de seu objeto, o que ele chamou de fato $\operatorname{social}^{28}$, o qual possui três características: a exterioridade, coercitividade e a independência em relação às manifestações individuais. É exatamente esse último elemento, a independência do fato social em relação às manifestações individuais que Durkheim teria garantido a distinção entre a Sociologia da Psicologia, pois enquanto a sociedade, formada pela exteriorização das ações individuais, seria o objeto da Sociologia, os indivíduos, com suas manifestações individuais e psíquicas, seriam objeto de investigação da Psicologia.

A tentativa depurativa de Durkheim de retirar o aspecto subjetivo do objeto da Sociologia justificava-se naquele contexto histórico, marcado pelo positivismo e pela necessidade de afirmá-la como um campo científico autônomo e independente. Contudo, a importância da subjetividade dos atores sociais nos estudos sociológicos ganhou força paulatinamente a partir do início do século XX, em especial com os estudos incipientes do que veio depois a ser chamado de interacionismo-simbólico ${ }^{29}$, bem como por meio das

\footnotetext{
${ }^{28}$ Influenciado pelas ideais do positivismo de August Comte e do darwinismo social de Herbert Spencer, Émile Durkheim concentrou boa parte de suas obras na construção e consolidação da Sociologia, preocupando-se com a delimitação do seu objeto e método-científico. Assim, além de fundar a revista renomada L'Anné Sociologique, que é editada até atualidade, ele escreveu as Regras do Método Sociológico (2003), onde definiu o objeto da sociologia como sendo o fato social, cujas características, basicamente, são: exterioridade, coercitividade e sua independência em relação às manifestações individuais. Em suas próprias palavras: "Fato social é toda a maneira de fazer, fixada ou não, suscetível de exercer sobre o indivíduo uma coerção exterior: ou então, que é geral no âmbito de uma dada sociedade tendo, ao mesmo tempo, uma existência própria, independente das suas manifestações individuais". (DURKHEIM, 2003, p. 40). O fato social estaria na sociedade, é vivido, criado e também influencia os próprios indivíduos ao mesmo tempo, mas deles se distingue. Imagine, por exemplo, um bolo de chocolate. Ele é feito de farinha, fermento, leite, manteiga e chocolate. Cada um desses ingredientes, separadamente, têm características distintas entre eles, mas juntos eles formam outra coisa, o bolo de chocolate, que não se pode dizer que é apenas leite ou manteiga, mas a união de todos os ingredientes. Juntos, eles formam algo de características, odor e textura própria. Assim seria a sociedade, um todo com textura, cor e sabor diferente dos ingredientes que a compõe, os indivíduos. Enquanto a sociedade seria objeto de estudo da sociologia, segundo Durkheim, os indivíduos seriam objetos da psicologia.

${ }^{29}$ Interacionismo simbólico foi um termo cunhado, em 1937, por Herbert Blumer, sociólogo da Universidade de Chicago, responsável por sistematizar e codificar o legado intelectual dos pioneiros do Departamento de Sociologia daquela
} 
críticas da própria epistemologia científica sobre a crise do paradigma da modernidade, que, ao transformar o saber científico em conhecimento regulador hegemônico, teria anulado o poder emancipatório de outras formas de conhecimento (SANTOS, 2000).

Com efeito, a assunção de que o próprio "saber científico" também é, de certa forma, resultado de representações sociais de seus próprios cientistas possibilita uma maior apreensão e compreensão da complexidade dos fenômenos sociais. Dessa forma, segundo Moscovici, reside aí a necessidade de se ter em conta o fenômeno das representações sociais nos estudos sociológicos.

A psicologia social é, obviamente, uma manifestação do pensamento científico e, por isso, quando estuda o sistema cognitivo ela pressupõe que: 1. Os indivíduos normais reagem a fenômenos, pessoas ou acontecimentos do mesmo modo que os cientistas ou os estatísticos, e 2. compreender consiste em processar informações. Em outras palavras, nós percebemos o mundo tal como é e todas nossas percepções, ideias e atribuições são respostas a estímulos do ambiente físico ou quase-físico, em que nós vivemos. O que nos distingue é a necessidade de avaliar seres e objetos corretamente, de compreender a realidade completamente; e o que distingue o meio ambiente é sua autonomia, sua independência com respeito a nós, ou mesmo, poderse-ia dizer, sua indiferença com respeito a nós e a nossas necessidades e desejos. O que era tido como vieses cognitivos, distorções subjetivas, tendências afetivas obviamente existem. Como nós, todos estamos cientes disso, mas eles são concretamente vieses, distorções e tendências em relação a um modelo, a regras, tidas como norma (MOSCOVICI, 2007).

O que chamamos realidade é impregnado de representações sociais, resultado de interpretações e ressignificações de fatos pelos atores sociais que lhe acrescentam sua perspectiva subjetiva, uma vez que as representações se entrecruzam e se cristalizam continuamente, através duma palavra, dum gesto ou duma reunião em nosso mundo cotidiano. Elas impregnam a maioria de nossas relações estabelecidas, os objetos que nós produzimos ou consumimos e as comunicações que estabelecemos (MOSCOVICI, 1976, p.40).

Moscovici alerta, inclusive, para a forte influência das representações sociais na produção do conhecimento (MOSCOVICI, 1976, p.40), apesar de defender que a "ciência e

universidade em 1920, que ficou conhecida como Escola de Chicago. Ele destacou "as significativas contribuições dos trabalhos para compreender a capacidade criativa da atividade humana diante do mundo social, a dimensão autorreflexiva utilizada pelos indivíduos diante das situações sociais, o incessante aspecto interpretativo realizado pelos indivíduos durante os processos interacionais". As condições que possibilitaram a produção criativa do que ficou conhecida como "Escola de Chicago" decorreram da própria interação com a cidade: um acelerado processo de industrialização, urbanização, e uma forte imigração que perpassava a sociedade norte-americana. Grandes sociólogos deixaram suas contribuições na Escola: Albion Small, Robert Park, John Dewey, George Herbert Mead, Louis Wirth, Everett Hughes, Loy Warner, Erving Goffman e Howard Becker são apenas alguns exemplos (MARTINS, 2013). 
representações sociais são tão diferentes entre si e ao mesmo tempo tão complementares que nós temos de pensar e falar em ambos os registros". (MOSCOVICI, 2007, p.57).

Ao mesmo tempo em que o conhecimento científico apresenta-se sistematizado e objetivado por meio de seu método, as representações sociais também se cristalizam na memória dos indivíduos, cujo processo, segundo Moscovici, se dá, por meio de dois mecanismos: ancoragem e objetivação.

Ancoragem é um processo automático de transformarmos algo estranho em familiar, uma vontade constante de classificar o estranho em alguma categoria familiar. Ela consiste em "transformar algo estranho e perturbador, que nos intriga, em nosso sistema particular de categorias e o compara com um paradigma de uma categoria que nós pensamos ser apropriada. (...) No momento em que determinado objeto ou ideia é comparado ao paradigma de uma categoria, adquire características dessa categoria e é reajustado para que se enquadre nela" (MOSCOVICI, 2007, p. 61). Ou seja, a ancoragem reflete a necessidade humana em categorizar tudo, um processo de encaixotamento, de colocar tudo na sua devida caixa ou categoria, mesmo que para tanto sejam necessários alguns ajustes na própria natureza do objeto a ser encaixotado. ${ }^{30}$

Do processo de ancoragem ou classificação, decorre uma segunda etapa diferente: a identificação. As consequências desse segundo processo são tríplices: a) uma vez nomeada, a pessoa ou coisa pode ser descrita e adquire certas características, tendências etc.; b) a pessoa, ou coisa, torna-se distinta de outras pessoas ou objetos, através dessas características e tendências específicas; c) a pessoa ou coisa toma-se o objeto de uma convenção entre os que adotam e adotam essa mesma classificação. "Ao nomear algo, nós o libertamos de um anonimato perturbador, para dotá-lo de uma genealogia e para inclúí-lo em um complexo de palavras específicas, para localizá-lo, de fato, na matriz de identidade de nossa cultura" (MOSCOVICI, 2007, p. 66).

Além da ancoragem, a cristalização das representações sociais também é caracterizada pela objetivação destinada a "descobrir a qualidade icônica de uma ideia ou ser impreciso, reproduzir um conceito em uma imagem” (MOSCOVICI, 2007, p. 71). Por meio da objetivação, conceitos e ideias abstratas tornam-se concretos a partir de uma imagem e se tornam "a realidade" com a repetição da vinculação dessa imagem à ideia, de forma que

\footnotetext{
${ }^{30}$ A neutralidade é proibida, pela lógica mesma do sistema, onde cada objeto e ser devem possuir um valor positivo ou negativo e assumir um determinado lugar em uma clara escala hierárquica. Quando classificamos uma pessoa entre os neuróticos, os judeus ou os pobres, nós obviamente não estamos apenas colocando um fato, mas avaliando-a e rotulando-a. Neste ato, nós revelamos nossa "teoria" da sociedade e da natureza humana. (MOSCOVICI, 2007, p. 61)
} 
aquela classificação, ao longo dos tempos, nem é mais passível de questionamento, porque ela se cristalizou.

Segundo Moscovici, ancoragem e objetivação são maneiras de lidar com nossa memória e é "dessa soma de experiências e memórias comuns que nós extraímos as imagens, linguagem e gestos necessários para superar o não-familiar, com suas consequentes ansiedades" $^{31}$ (MOSCOVICI, 2007, p. 78).

Assim, ter a consciência de que nossas memórias e nossa comunicação são, em todo momento, impregnadas dessas representações sociais, que, por sua vez, são resultado desses processos de ancoragem e objetivação ao longo do tempo, é imprescindível para interpretar não apenas o conteúdo verbal das entrevistas, mas observar os gestos, os comportamentos e, principalmente, a interação entre os atores sociais envolvidos com a atividade de prostituição e a cidade.

Nesse contexto, a perspectiva do fenômeno das representações sociais enriquece ainda mais o elemento subjetivo do dispositivo, qual seja, buscar realçar os ditos, os interditos e os não-ditos dos atores sociais, e suas relações com o espaço, no caso, a avenida W3 norte.

Ademais, a perspectiva das representações sociais é fundamental para analisar como as diversas narrativas sobre as relações entre prostituição, cidade e criminalidade, cristalizadas na forma de classificações, conceitos e imagens, foram e são influenciadas pelos campos da moral, religião, medicina, direito e sociologia, e vice-versa, em diferentes locais e períodos históricos. Essa análise histórica é importante, porque as representações sociais hoje existentes, com as suas racionalidades e contradições internas, são resultado de rearranjos cognitivos, ao menos parciais, das representações que existiam no passado. Esse é o próximo assunto.

\subsection{Narrativa moral/religiosa}

Não se pode dizer que a prostituição é a profissão mais antiga do mundo. Ao contrário desse constante clichê, a atividade de prostituição, em diversas civilizações da Antiguidade, não era um ofício ou uma profissão, mas um ato de sacrifício aos deuses ${ }^{32}$.

\footnotetext{
${ }^{31}$ As experiências e memórias não são nem inertes, nem mortas. Elas são dinâmicas e imortais. Ancoragem e objetivação são, pois, maneiras de lidar com a memória. A primeira mantém a memória em movimento e a memória é dirigida para dentro, está sempre colocando e tirando objetos, pessoas e acontecimentos, que ela classifica de acordo com um tipo e os rotula com um nome. A segunda, sendo mais ou menos direcionada para fora (para outros), tira daí conceitos e imagens para juntá-los e reproduzi-los no mundo exterior, para fazer as coisas conhecidas a partir do que já é conhecido. (MOSCOVICI, 2007, p.78)

${ }^{32}$ Ao longo da história, à prostituição já foram atribuídos diversos significados, desde os mais elevados propósitos religiosos, como vestais a serviço de rituais de purificação, à representação da sodomia e devassidão (GAVRIS \& BANCIU, 2009).
} 
No entanto, não será necessário recuar até os tempos antigos, para cumprir nossa finalidade de recuperar as principais narrativas sobre a prostituição responsáveis pelas suas atuais representações sociais, reproduzidas pelo imaginário social. Assim, convém iniciar o estudo referente ao período de passagem da Baixa Idade Média para a Idade Moderna, que compreende os séculos XV ao XVIII, marcados por acontecimentos como a Renascença, a Reforma Protestante e a invenção do tipo móvel de impressão por Gutenberg.

No início desse período, uma nova narrativa de controle social, capaz de reunir uma grande quantidade de energia social em torno de um ideal comum, surgiu: a necessidade de “contenção e eliminação de um mal que ameaçava a existência da humanidade, primeiro como heresia e depois como bruxaria (o mal cósmico do Maligno)" (ZAFFARONI e BATISTA, 2003, p. 277-278). Assim, as instituições como o nascente Estado nacional e a Igreja seriam responsáveis por executar medidas contra esse inimigo comum, responsável de todas as mazelas sociais. O maior exemplo executor dessa narrativa de controle, no período indicado, foi a instituição denominada Santa Inquisição, criado no século XII, mas que ganhou maior alcance no contexto da Reforma Protestante, como parte da Contrarreforma.

A Inquisição foi um tribunal jurídico-teológico, cujos membros eram sacerdotes-juristas letrados. Tais especialistas foram, em um primeiro momento, fanáticos, mas, depois, passaram a se apresentar como funcionários, que cumpriam a sua obrigação com frieza despersonalizada, digna de um grupo profissionalizado (ANITUA, 2007, p. 53). Tratou-se da primeira agência burocratizada dominante cuja função era a definição de "verdade" e a aplicação de castigos a partir dela. (ANITUA, 2007, p. 54).

Ao voltar o seu poderoso aparato burocrático contra as chamadas bruxas, a narrativa da Inquisição consolidou a submissão de metade da espécie humana - as mulheres - ao patriarcado punitivo (ZAFFARONI e BATISTA, 2003, p. 278). A Inquisição transformou a figura da mulher no "outro" por excelência, ao lado de outros grupos estigmatizados, como os leprosos e os judeus, todos eles assinalados como inferiores e merecedores de desconfiança, controle e repressão (ANITUA, 2007, p. 55). Ou seja, com esse movimento, a representação social da mulher passou a ser associada com a ideia de inferioridade, bem como a ser relacionada com outras categorias também tidas como inferiores, compartilhando com eles certas características.

O processo de redefinição da representação social da mulher por parte da Inquisição chegou ao seu máximo refinamento teórico com o "Martelo das Feiticeiras" (Malleus Maleficarum), elaborado por Heinrich Kramer e James Sprenger, um manual que ensina, a partir da perspectiva assinalada, "as causas do mal, suas formas de aparecimento, seus 
sintomas e os modos de combatê-lo, isto é, integrando em um único saber ou discurso a criminologia etiológica, o direito penal e processo penal e a criminalística" (ZAFFARONI e BATISTA, 2003, p. 278).

Mas por que escolher a mulher como alvo dessa intensa perseguição? Em primeiro lugar, os autores do "Martelo das Feiticeiras" consideram a mulher como um ser espiritual e biologicamente inferior, em razão de ter surgido da costela de Adão. Isso é importante, porque, ainda de acordo com os inquisidores, a costela é curva, o que impediria a mulher de alcançar a retidão moral dos homens (KRAMER e SPRENGER, 2015, p. 124). Essa inferioridade tornaria as mulheres especialmente débeis à sedução do Diabo. E é essa cumplicidade, essa relação íntima com o Diabo, que é a principal característica da bruxa, tudo mais são apenas sinais para identificá-la.

Certo é que os inquisidores consideraram que, por vontade de Deus, é grande o poder do Diabo sobre o ato sexual. Nesse contexto, consideram a luxúria como o maior dos vícios femininos, e é por meio dela que o Diabo seduz a mulher, tornando-a sua cúmplice, uma bruxa. Por isso, concluem que as bruxas seriam aquelas com maior propensão a esses atos de luxúria (KRAMER e SPRENGER, 2015, p. 129-130). Assim, associam a ideia de mulher à fraqueza moral e à suscetibilidade aos prazeres da carne.

O "Martelo das Feiticeiras" não traz ataques diretos às prostitutas, mas é bem eloquente ao caracterizar como cúmplices do Diabo todas as mulheres com comportamento fora dos padrões morais vigentes, ou que assumam um papel de maior assertividade, seja no espaço público ou no curso de uma relação sexual, sinais identificadores de bruxas.

O resultado de séculos de perseguição foi a ampla ressignificação da figura da mulher e do feminino no imaginário social, nos termos acima indicados. Antes da era da "caça às bruxas", a mulher era senhora de um saber específico, em especial nas áreas da cultura e da medicina, mas, depois, acabou por assumir uma posição de dependência total relação à figura masculina. Naturalmente, a origem histórica do domínio masculino é muito anterior, mas a Inquisição cristalizou e consolidou essa posição de inferioridade da mulher, a partir de uma narrativa religiosa-moralista. Somente no século XIX, haveria uma sobreposição dessa narrativa por outra, de natureza médico-policial, que, no entanto, não modificaria essa posição de inferioridade da mulher e do feminino na sociedade. É o que se verá a seguir. 


\subsection{Narrativa médica higienizadora}

Com a consolidação da sociedade moderna, especialmente ao longo do século XIX, apareceram novas narrativas, que relacionaram, mais uma vez, o desvio, o feminino e a prostituição. O moralista, laico ou religioso, perde espaço, primeiro, para os médicos e, depois, para os criminólogos ${ }^{33}$.

Com a passagem do século XVIII para o século XIX, a agora hegemônica burguesia deparou-se com o problema de como gerenciar a enorme massa humana que, ao longo das últimas décadas, acumulara-se nas grandes cidades. A narrativa igualitarista do contrato social, muito útil para a burguesia derrubar o Antigo Regime e a sua aristocracia, mostrava-se inadequada como fundamento para uma política de repressão e controle social voltada contra os grupos sociais menos favorecidos. Outras narrativas, porém, estavam disponíveis para cumprir essa função.

Antes de examiná-las, é necessário lembrar que no século XIX, a narrativa dominante era a de confiança quase infinita na capacidade de a ciência conduzir a humanidade a um futuro mais luminoso, modificando não só a pessoa, mas também a própria sociedade. Claro que nem todos tinham o mesmo sonho, mas o pensamento das camadas intelectuais estava dominado pela insatisfação com a sociedade de até então e a necessidade de construir algo melhor, uma utopia.

É nesse contexto que, já na primeira metade do século XIX, o saber médico surge como o novo fundamento para a gestão dos indesejados. Chama-se higienismo o movimento médico que busca intervir não mais apenas na saúde do indivíduo, mas na de toda a sociedade, ou seja, que pretende cuidar da chamada saúde pública. Para tanto, utiliza categorias médicas, a fim de descrever os problemas sociais, bem como a "profilaxia" necessária para curá-los.

Uma das principais soluções propostas pelos médicos higienistas, para os problemas assinalados, é a reformulação das grandes cidades, que eram vistas "como um foco de

\footnotetext{
${ }^{33}$ De igual maneira, o tratamento dado aos deficientes físicos também passou por essas fases de narrativa moral/monstruosa, médica/doença, jurídica, no sentido de ser deficiente físico. Utilizando também o conceito de dispositivo de Foucault, JeanJacques Courtine estudou as mudanças de perspectiva de tratamento de corpos com deficiências ou anomalia ao longo dos anos de 1840-1940, a partir da ideia de dispositivo de "anormalidade". Courtine identifica uma mudança no tratamento das percepções da deformidade, antes um monstro, para um deficiente físico (handicap). O dispositivo do deficiente, inicialmente, era o resultado de elementos e forças que o viam como um monstro e envolvia noções de exibicionismo, voyeurismo de massa, exotismo, apresentação da imagem invertida, da cultura visual da deformidade, da teratologia científica. A mudança da perspectiva se dá com o nascimento de outro resultado da interação de forças e elementos que o constituíam, de forma a modificar o conteúdo do dispositivo inicial, para a predominância do discurso biológico, no qual é dado ao médico o poder de considerar o "corpo anômalo" como um doente, restrito à observação médica, atribuindo significação negativa ao exibicionismo do período anterior. "A curiosidade pelos monstros humanos, qual ela se exerce fora da esfera médica, será viciosa, insana, perversa: uma infração repreensível em relação à lei e simultaneamente uma tara psicológica em relação à norma". (COURTINE, 2013, p. 131).
} 
pestilência física e moral que precisava ser destruída" (ANITUA, 2008, p. 243). Era necessária a eliminação da parcela do espaço urbano que permitia a proliferação de doenças como matadouros e cemitérios -, bem como de "elementos perigosos", como anarquistas, vagabundos, delinquentes, libertinos e prostitutas, disseminadores de doenças. Esses problemas substituíram a lepra, a peste negra e a bruxa como "os inimigos públicos número um" da sociedade. A partir daí, a população passa a ser dividida entre os indivíduos saudáveis e os doentes. O último grupo deve ser objeto de tratamento. Ou seja, há a divisão entre os normais e os inferiores, sendo que a nova moral burguesa forneceria o modelo do que será considerado, nesse contexto, como "normalidade".

Nesse âmbito, os higienistas preocupavam-se especialmente com duas questões: a doenças mentais e as doenças venéreas.

As figuras do louco, do alienado e do degenerado eram interpretadas de forma muito ampla. A maior parte das pessoas que integravam grupos tidos como desviantes eram enquadrados nessas categorias. Alguns dos higienistas, por exemplo, consideravam que "todo delito seria um fenômeno patológico, causado pela interação de fatores biológicos hereditários e sociológicos ambientais" (ANITUA, 2008, p. 249). O tratamento indicado para esse tipo de "patologia" era o confinamento terapêutico, o que levou ao encarceramento de grandes contingentes da população. Entendia-se que esses indivíduos careciam da capacidade de repressão dos impulsos e de autodisciplina, e, por consequência, deveriam ser confinados até adquirir essas habilidades (ANITUA, 2008, p. 247). Ou seja, no âmbito das representações sociais, os grupos cuja inferioridade era, antes, explicada em termos morais, religiosos ou mesmo sobrenaturais, nesse novo modelo, passaram a ter a sua inferioridade explicada e reforçada em termos médico-científicos.

Nesse contexto, a prostituição afigura-se como uma das preocupações centrais do higienismo, tanto por seu papel como vetor de transmissão de doenças venéreas, como fator de degradação moral do corpo social. Oferece, assim, uma roupagem médico-científica para as questões morais do passado. Aliás, essa vertente moralizadora fica ainda mais clara, quando se observa a sua preocupação com modelos "corretos" de sexualidade e de vida cotidiana, inclusive para o controle do crescimento demográfico ${ }^{34}$ (ANITUA, 2008, p. 244). Aliás, a preocupação, no período, com o comportamento feminino não recaía apenas sobre as prostitutas, mas também as mulheres solteiras e pobres, em especial, aquelas que trabalhavam

\footnotetext{
${ }^{34}$ Essa preocupação inicia-se com os estudos de Malthus, segundo o qual "a tendência da população a aumentar é maior do que a mesma tendência nos alimentos e que, por isso, a natureza cria freios para a população, relacionados com a miséria, as doenças e as guerras" (MALTHUS, 2008, p. 241). Malthus entendia que o controle da natalidade através da continência moral era uma forma mais humana de lidar com o problema do que aquela oferecida pela natureza.
} 
nas nascentes indústrias, que eram também alvos dessa nova política repressiva (SCOULDER, 2004, p. 350). Era mal vista a mulher que estivesse em via pública sem a companhia masculina (ANITUA, 2008, p. 245). Nessa tarefa, os higienistas contaram inclusive com o apoio dos movimentos de mulheres da época, que buscava resgatar e proteger essas "meninas perdidas", sem dar atenção ao que essas mulheres achavam desse suposto “cuidado" (SCOULDER, 2004, p. 350-351). ${ }^{35}$

Na segunda metade do século XIX, esse pensamento médico vai se transformar em um dos principais fundamentos da narrativa da criminologia positivista.

A criminologia positivista considera a anormalidade individual do autor como a explicação universal do crime, embora, em algumas das suas vertentes, seja admitida a influência de condicionantes sociais. A categoria central aqui seria a do "homem delinquente", que seria tratado como uma raça, uma espécie diferente dos seres humanos normais.

Trata-se de uma união da nascente instituição policial com a corporação dos médicos, com contribuições ainda da sociologia e da antropologia (ZAFFARONI e BATISTA, 2003, p. 281-282).

Da antropologia da época, a criminologia positivista extrai principalmente a categoria de raça, que é estruturada de forma que todo comportamento que não corresponde ao ideal burguês europeu é derivado do pertencimento da pessoa a uma raça inferior. Assim, nessa perspectiva, às classes perigosas do higienismo (a prostituta, o delinquente, o louco etc.) juntam-se o asiático, o negro, o judeu, entre outros.

Cesare Lombroso ${ }^{36}$ é o fundador e o ícone maior desse movimento. Seu pensamento possui dois momentos.

No primeiro, o criminoso era uma espécie de louco moral, cujo comportamento é explicado em termos psicossomáticos, que tem por causa um atavismo, ou seja, um atraso evolutivo, quando comparado com as pessoas tidas como "normais". O criminoso era um salto atrás na marcha evolutiva descrita por Darwin. Ele comporta-se de forma desviada, porque seu desenvolvimento foi interrompido antes de alcançar a maturidade moral, aqui caracterizada em termos biológicos (ANITUA, 2008, p. 304). Seria ainda possível reconhecer

\footnotetext{
35 Estratégias segregacionistas espaciais relacionadas à prostituição também foram adotadas, aliadas ao discurso moralhigienista, dentro dos grandes centros urbanos. Esse assunto, porém será melhor tratado no capítulo 1 "A cidade e a prostituição".

${ }^{36}$ O médico italiano Cesare Lombroso viveu de 1835 a 1909. Foi professor de medicina forense e higiene, psiquiatria e antropologia criminal. É considerado o fundador e principal ícone da criminologia positivista. Era judeu, e, diante das suas visões racistas e dos acontecimentos históricos da perseguição dos judeus nos séculos XIX e XX, não deixa de ter uma triste ironia.
} 
esse atraso evolutivo por alguns sinais exteriores, como algumas particularidades do crânio, e, por consequência, agir sobre o criminoso de forma preventiva, antes de ele praticar o crime.

Mais tarde, Lombroso iria ampliar o rol de causas do crime, incluindo o ambiente social como um dos condicionantes do crime, mas sem descaracterizar a principal característica do positivismo criminológico: a explicação do crime a partir de um defeito particular do indivíduo.

As mulheres, para Lombroso, são classificadas como um dos grupos tidos como biologicamente inferiores. Ele dedicou especial atenção às prostitutas, reforçando assim o padrão da narrativa iniciada pelos higienistas.

Em sua obra "A Mulher Delinquente", escrita conjuntamente com o seu genro Guglielmo Ferrero, a mulher ocupa um lugar inferior na escala evolutiva humana. Na obra, as mulheres são caracterizadas da seguinte forma:

\footnotetext{
"a mulher normal é por natureza menos sensível à dor do que o homem. Em razão da compaixão ser um efeito da sensibilidade, se a pessoa carece desta, carecerá daquela também. Nós temos visto que a mulher tem também muitas características em comum com as crianças, pois ambos são deficientes em um sentido moral, além de vingativos, invejosos e tendentes a uma crueldade refinada quando levam a cabo uma vingança. Usualmente esses defeitos são neutralizados pela sua piedade, maternidade, frigidez sexual, fraqueza física e inteligência subdesenvolvida" (LOMBROSO e FERRERO, 2007, p. 3269-3270).
}

Concluem que, embora seja menos frequente que a mulher se dedique a atividades criminosas, quando o faz, age com maior selvageria (LOMBROSO e FERRERO, 2007, p. 3257). Consideram ainda que essas poucas mulheres criminosas aparentavam ser homens (LOMBROSO e FERRERO, 2007, p. 3176). Isso é importante, porque, para Lombroso, atavismo era a regressão a um tipo evolucionário anterior, e, no passado, as diferenças biológicas entre homens e mulheres seriam menos acentuadas, o que explicaria a referida semelhança (LOMBROSO e FERRERO, 2007, p. 2659) ${ }^{37}$.

Lombroso e Ferrero apresentam ainda outra razão para o pequeno número de mulheres entre os autores de crimes: a inferioridade da mulher não seria externalizada na prática de crimes, mas sim por meio da prostituição. A prostituição seria a forma específica da delinquência feminina (LOMBROSO e FERRERO, 2007, p. 4109). Assim como acontecia na

\footnotetext{
${ }^{37}$ Lombroso extraiu essa conclusão a partir do exame do fenótipo das mulheres nas populações nativas da América do Norte e da África, que ele enxergava como raças atrasadas e primitivas, e, por consequência, um retrato do passado da raça branca européia. Assim, qualquer semelhança da mulher com essas raças inferiores, constituiria indicação de atavismo, e, por consequência, da sua propensão para a criminalidade e prostituição (LOMBROSO e FERRERO, 2007, p. 2659).
} 
delinquência masculina, a prostituição era causada por uma predisposição orgânica à loucura moral decorrente da hereditariedade dessa mulher. Todavia, os autores reconhecem que, ao menos, a delinquência feminina era menos temível que a masculina, e que servia a uma função social, qual seja, oferecer uma válvula de escape para a sexualidade masculina, podendo, nessa função, inclusive evitar delitos (ANITUA, 2008, p. 306-307). A prostituta, então, é duplamente estigmatizada: é mulher e é delinquente. E mais, os referidos autores consideravam que a inferioridade presente na mulher prostituta era ainda mais intensa do que aquela presente na mulher criminosa, pois, no primeiro grupo, os sinais de atavismo estariam estatisticamente mais presentes (LOMBROSO e FERRERO, 2007, p. 2822), com a obesidade (LOMBROSO e FERRERO, 2007, p. 2659).

Diversos autores ${ }^{38}$ continuaram o trabalho de Lombroso, acrescentando novas e importantes categorias à criminologia positivista, como a periculosidade, retratada em uma "perversidade constante e ativa" 39 . Assim, as criminosas seriam perigosas e, por isso, deveriam ser eliminadas ou segregadas.

A partir da ideia de periculosidade, os criminólogos positivistas desenvolveram a categoria do "estado perigoso sem delito". Esse estado estava presente no que eles chamavam de "má vida", na qual "incluía a mendicidade, a prostituição, o jogo, as religiões não-oficiais, a toxicomania e tudo aquilo que não se adequasse ao modo de vida burguês ou ao seu similar de imitação pelos proletários disciplinados" (ANITUA, 2008, p. 315). Para eles, esse submundo era o contrário da civilização e do progresso, e somente poderia ser explicado pelo atraso e pelo atavismo.

Todavia, esse novo domínio da narrativa biopolicial não promoveu o desaparecimento das narrativas moralistas anteriormente hegemônicas do campo de estudo. Elas permanecem na disputa, buscando novas formas de apresentar a sua narrativa em concorrência com as demais, na expectativa de, mais uma vez, se tornar dominante. Por exemplo, as bruxas de antes são as portadoras das doenças do espírito nessa nova época, e, principalmente, suas disseminadoras. Percebe-se, assim, claramente a continuidade da narrativa moralista, agora

\footnotetext{
${ }^{38}$ Ferri, por exemplo, ampliou a tipologia dos delinquentes, que passaram a ser classificados como: nato, louco, habitual, ocasional e passional. A tendência a delinquir dos dois primeiros teria base orgânica, e, no terceiro (criminoso habitual), ela teria sido adquirida socialmente. Já o criminoso ocasional e o passional praticam crimes apenas se as condições forem propícias para tanto. Seria essa tipologia, e não o fato praticado, que indicaria a sanção a ser imposta no caso de delito, bem como a possibilidade de adoção do que Ferri denomina de substitutivos penais, medidas pré-delituais de controle social (ANITUA, 2008, p. 313). Tal modelo expande significativamente os instrumentos disponibilizados aos agentes estatais para lidar com as "classes perigosas".

${ }^{39}$ Garófalo introduziu a ideia de periculosidade, que seria uma "perversidade constante e ativa". Recomendou ainda que a pena não deveria ser proporcional ao dano causado, mas sim à periculosidade do autor (ANITUA, 2008, p. 314). Defendia, inclusive, a pena de morte para o caso dos irrecuperáveis, pois assim se estaria cumprindo a lei da seleção natural, impedindo-se que a sociedade como um todo degenerasse.
} 
sob uma nova roupagem. No Brasil, essa narrativa higienista chegou ainda na primeira metade do Século XIX ${ }^{40}$.

Entre outros objetivos, os médicos higienistas buscavam "explicar a prostituição enquanto um fenômeno ao mesmo tempo natural e social e tentavam desenvolver um melhor conhecimento e maior controle de um fato que a sociedade, na impossibilidade de removê-lo, via-se obrigado a tolerar" (SOARES, 1992, p. 16). Nesse sentido, a prostituição seria uma ameaça à sociedade, capaz de corromper os seus alicerces, entre outras coisas, porque representava um perigo para o patrimônio das famílias de seus clientes e para a própria ideia de trabalho, "desestimulando-o e criando a ilusão de uma vida fácil e luxuosa para as suas praticantes" (SOARES, 1992, p. 85). Por outro lado, a prostituição seria um fenômeno inevitável, pois "teria um papel estabilizador na sociedade, permitindo que o homem pudesse descarregar a excitação causada pela necessidade imperiosa do prazer venéreo, sem provocar grandes problemas na organização social" (SOARES, 1992, p. 17). A par disso, os higienistas consideravam ainda as grandes aglomerações humanas, como um fator determinante para o surgimento da prostituição (SOARES, 1992, p. 16).

A ideia de inevitabilidade da prostituição é central para os higienistas, e está presente ainda hoje nas narrativas sobre o tema, como se verá especialmente no Capítulo 4, que trata, entre outras, das narrativas dos clientes acerca da prostituição. Seria impossível e indesejável extingui-la. Diante disso, muitos deles recomendavam a regulamentação da prostituição. Mas essa regulamentação nada tem a ver com o atual movimento de regulamentação, que busca conferir melhores condições de trabalho e direitos trabalhistas e previdenciários para as prostitutas. A regulamentação da prostituição para os higienistas passava, entre outras medidas, pela sua concentração em casas especiais em determinadas áreas - para pôr fim à sua disseminação desenfreada pela cidade e facilitar o seu controle por parte da polícia - e a sua submissão a um controle médico-hospitalar - consubstanciada em visitas periódicas por parte de médicos e, caso este constatasse alguma doença venérea, a prostituta seria forçosamente internada para tratamento (SOARES, 1992, p. 87). Ou seja, a ideia era submeter a prostituição a um controle policial e médico, com a possibilidade de recorrer inclusive a instituições totais, como hospitais, com o objetivo de realizar o referido controle, o que não é

\footnotetext{
${ }^{40}$ A chegada do higienismo no Brasil é objeto de muitos estudos, que tratam, por exemplo, do papel de Oswaldo Cruz nesse movimento, bem como das reformas de Pereira Passos e da 'Revolta da Vacina'. Exemplificam essa produção a tese de doutorado de Neiva Vieira da Cunha "O Espírito do Sanitarismo: Narrativas de Profissionais da Saúde Pública dos anos 30" (2002) e o artigo de Marco Antônio da Silva Mello "Rito e Símbolo na Cosmologia do Sanitarismo: Considerações sobre a história e a memória urbana do Rio de Janeiro" (2005).
} 
muito diferente daquilo que, no mesmo período, já acontecia com outros grupos "perigosos", como os criminosos e os loucos.

Observa-se ainda que, seguindo os ventos positivistas da época, os higienistas procederam a uma cuidadosa classificação das diferentes espécies de prostituição. Na obra do médico Lassance Cunha (1845), ele, em primeiro lugar, propõe a divisão entre a prostituição pública e a clandestina, esta última praticada por mulheres com outras ocupações, como costureiras e floristas. Mas a principal espécie de prostituta clandestina era a escrava, que tinha, no comércio do sexo, uma importante fonte de renda, inclusive para a compra de sua alforria, e esses lucros, muitas vezes, era compartilhado com o seu senhor, cuja cumplicidade, grosso modo, era indispensável para esse empreendimento. Por sua vez, esse autor dividia a prostituição pública em primeira, segunda e terceira ordem. As de primeira ordem eram frequentadas por homens ricos, e viviam isoladas em casas de sobrado decentes. Já as de segunda ordem prestavam serviços para homens das classes remediadas da sociedade. As prostitutas públicas de terceira ordem eram "aquelas da mais baixa categoria, que viviam em tenebrosas casas, entregando-se aos excessos da libertinagem e aos libertinos. Eram frequentadas pelas pessoas da mais baixa condição social” (SOARES, 1992, p. 28-29).

Todavia, apesar das pretensões científicas, a linguagem utilizada pelos higienistas deixa clara a forte presença de preocupações morais nessa narrativa, a par daquelas de ordem médica, como se percebe, por exemplo, do conceito de prostituição apresentado pelo higienista Francisco Ferraz de Macedo: “é o uso da cópula natural por depravação dos costumes, o da cópula antifísica e o do seu arremedo por quaisquer práticas imorais" (SOARES, 1992, p. 31). Observa-se, em Lassance Cunha, a tendência da época em enumerar as causas da prostituição (SOARES, 1992, p. 18-19). Para ele, a prostituição seria ocasionada pelos seguintes fatores, entre outros: a sedução de meninas e o posterior abandono por seus sedutores; o abandono das mães por seus maridos; as desordens domésticas; a miséria; a ociosidade dos mancebos descendentes das famílias opulentas e poderosas; o esquecimento da doutrina cristã e da virtude; a falta de educação moral, principalmente entre as mulheres (SOARES, 1992, p. 18-19). Entendia-se, na época, como desordens domésticas, algo próximo do que hoje chamaríamos de violência doméstica.

A essas causas, mais gerais, os higienistas somam outra, que marca especialmente a sociedade brasileira: a escravidão. Para eles, o negro seria "bronco, rude e estúpido por natureza e por educação, ignorando o que seja pudor, não compreendendo nenhum sentimento de moral ou de virtude, é de um temperamento erótico, e consequentemente muito libidinoso" (SOARES, 1992, p. 20). Ademais, a existência de escravos geraria preguiça, indolência, a 
soberba, a vaidade e a tirania do senhor, bem como criaria, mesmo entre os mais pobres, uma vergonha e ojeriza ao trabalho tido como típico dos escravos (SOARES, 1992, p. 19). Por fim, as escravas mulheres negras ${ }^{41}$ exerceriam uma influência corruptora sobre a família, seja pela sua proximidade com as jovens damas, seja seduzindo os jovens mestres para as suas camas, o que, para alguns higienistas, seria uma forma de prostituição (SOARES, 1992, p. 19). Tal raciocínio não deve causar espanto, pois, como vimos acima, o higienismo caminhava de mãos dadas com as teorias racistas da época, especialmente em regiões escravistas, como o Brasil do século XIX.

Por outro lado, consideravam que não estaria presente, no Brasil, circunstâncias que favoreciam o crescimento da prostituição na Europa ocidental: as grandes cidades, o excesso de população, a falta de trabalho, os mesquinhos salários, a miséria, a promiscuidade dos sexos no interior das fábricas, exércitos numerosos etc. (SOARES, 1992, p. 21).

Mais tarde, também o positivismo criminológico foi trazido para o Brasil principalmente pela obra do médico baiano Nina Rodrigues ${ }^{42}$, mais precisamente na segunda metade do século XIX, e manteve a sua hegemonia acadêmica na Europa e na América até a eclosão da Primeira Grande Guerra.

Com o desenvolvimento da biologia, da antropologia, da sociologia, e redução da crença na onipotência da ciência, a criminologia positivista na sua forma clássica perdeu influência no campo acadêmico das ciências sociais, que se afastaram de uma ideia de "física social". Sabe-se que, com o passar das décadas, a ideia central da criminologia positivista (a explicação da criminalidade por meio de deficiências biológicas do autor do fato) assumiu novas roupagens, como na criminologia genética e hormonal, mas essas novas correntes não chegaram nem perto de alcançar a força hegemônica que a criminologia positivista apresentava no passado. Contudo, essa narrativa manteve sua força tanto na cristalização dessas representações sociais, quanto no campo burocrático, pela incapacidade de o campo

\footnotetext{
${ }^{41}$ A expressão "Preta, Pobre e Puta", uma representação social bem cristaliza na sociedade brasileira para se referir ao baixo meretrício e foi utilizada, inclusive, como título de tese de doutorado de Diana Helene Ramos, por se referir a uma categoria nativa utilizada por uma de suas entrevistadas prostituta, Natasha, moradora do bairro Jardim Itatinga, cuja história remete à segregação urbana espacial da prostituição (RAMOS, 2015).

${ }^{42}$ Nina Rodrigues viveu de 1862 a 1906, e atuou como médico, psiquiatra, antropólogo e professor. Fortemente influenciado pela obra do Lombroso, a sua obra voltou-se principalmente para a caracterização do negro como uma raça inferior. Para compreender essa característica da sua obra, basta ler, por exemplo, o seguinte excerto da sua obra "O Africanos no Brasil": "Como a extinção do tráfico, a da escravidão precisou revestir a forma toda sentimental de uma questão de honra e pundonor nacionais, afinada aos reclamos dos mais nobres sentimentos humanitários. Para dar-lhe esta feição impressionante foi necessário ou conveniente emprestar ao Negro a organização psíquica dos povos brancos mais cultos. Deu-se-lhe a supremacia no estoicismo do sofrimento, fez-se dele a vítima consciente da mais clamorosa injustiça social. (...). O sentimento nobilíssimo da simpatia e piedade, ampliado nas proporções de uma avalanche enorme na sugestão coletiva de todo um povo, ao Negro havia conferido, ex- autoridade própria, qualidades, sentimentos, dotes morais ou ideias que ele não tinha, que ele não podia ter; e naquela emergência não havia que apelar de tal sentença, pois a exaltação sentimental não dava tempo nem calma para reflexões e raciocínios" (RODRIGUES, 2010, p. 10-11).
} 
intelectual produzir um novo discurso capaz de servir como legitimação do poder punitivo estatal, como se perceberá, a seguir, na análise das narrativas desenvolvidas pelos juristas ao longo do século XIX sobre a prostituição.

\subsection{Narrativa jurídica}

A discussão dos higienistas sobre a regulamentação da prostituição não passou em branco entre os juristas.

Ainda no final do século XIX, o advogado Evaristo de Morais ${ }^{43}$ manifestava-se contra a regulamentação, pois

doutrinariamente, a ciência moderna condena a repressão direta ao Vício, por considerá-la ineficaz. A embriaguez, a prostituição e a mendicidade, até mesmo o jogo, quando punidos, somente proliferam novos meios de exploração policial ou geram opressões e brutalidades de toda ordem, desumanas e inúteis. [...] Por toda parte, a regulamentação, como a desejam aqui, aumentando a tirania policial e a prostituição clandestina, não impede exibições impudicas, convites francos, aglomerações indecentes (SOARES, 1992, p. 92).

Ademais, Evaristo de Moraes considerava que “a razão da 'enorme grita' era a intenção de reprimir as meretrizes pobres que moravam nas ruas Senhor dos Passos, Sete de Setembro e outras próximas, "as baixas rameiras, as pobres mercadoras de amor barato". Enquanto isso, os "regulamentaristas" mostravam-se condescendentes com as pecadoras d'alto bordo (...)" (SOARES, 1992, p. 92).

Mas nem todos os juristas discordavam do ideal higienista. Ao tratar dos crimes relacionados à exploração da prostituição (lenocínio e tráfico de mulheres), Hungria ${ }^{44}$ justificava a criminalização de tais condutas, mesmo não sendo a própria atividade de prostituição um crime, uma vez que, a prostituição deveria ser "tolerada como uma fatalidade da vida social, mas a ordem jurídica faltaria à sua finalidade se deixasse de reprimir aqueles que, de qualquer modo, contribuem para maior fomento dessa chaga social" (HUNGRIA,

\footnotetext{
${ }^{43}$ Evaristo de Morais foi um famoso advogado brasileiro, cuja atuação se estendeu do final do século XIX até metade do século XX. Notabilizou-se pela sua atuação no Tribunal do Júri, e pela defesa das questões laborais. Participou da elaboração da Consolidação das Leis do Trabalho (CLT), no curso do Governo Vargas, e também foi um dos fundadores do Partido Socialista, que participava da Segunda Internacional.

${ }^{44}$ Nélson Hungria foi um dos mais importante penalistas da história jurídica brasileira. Foi ministro do Supremo Tribunal Federal, e um dos autores do projeto que acabou por se transformar no Código Penal de 1940, cuja Parte Especial (onde são tratados dos crimes em espécie) continua em vigor até os dias de hoje, com algumas modificações pontuais. A sua obra "Comentário ao Código Penal" é ainda hoje uma das mais prestigiadas obras sobre o assunto, principalmente no que concerne à Parte Especial. No presente trabalho, faz-se referência ao Volume VIII desta obra, cuja edição original é de 1948, apesar da edição de consulta ser de 1981.
} 
1981, p. 260). Não se criminalizava, portanto, as prostitutas, mas quem fomentasse sua atividade. Dizia também, Hungria, que, com a criminalização do lenocínio e do tráfico de mulheres, buscava-se punir os "parasitas do vil mercado dos prazeres sexuais" (HUNGRIA, 1981, p. 259). Assim, há uma reprodução nesse pensamento de elementos da narrativa higienista - a inevitabilidade da prostituição e a necessidade de controlá-la - e moralista - a reprovabilidade das atividades que orbitam a prostituição ${ }^{45}$. A alternativa a um não controle da prostituição, no caso, seria a proliferação da criminalidade sexual e do adultério.

Cogitar o reconhecimento de amplas liberdades para a atividade de prostituição era inaceitável para Hungria, pois tal medida implicaria o retorno a tempos pretéritos, quando tribos selvagens não cuidavam do "velamento da atividade sexual" (HUNGRIA, 1981, p. 268). Para ele, a única solução possível é a liberdade vigiada da prostituição, um meio termo entre a proibição e autorização plenas.

Nesse contexto do controle, Hungria classificava as pessoas que se dedicavam à exploração da prostituição nos seguintes grupos: o traficante de mulheres (responsável pelo recrutamento e transporte, de um lugar para o outro, das mulheres destinadas à prostituição), o proxeneta $^{46}$ (que realiza a mediação para que a mulher satisfaça a lascívia de outrem, ou que mantém “casa de prostituição") e o rufião (que é aquele que se aproveita de forma parasitária dos ganhos da prostituição) (HUNGRIA, 1981, p. 259).

Ainda para Hungria, o rufião pode assumir uma forma passiva e outra ativa. Na forma passiva, o agente recebe vantagem da prostituta, por esta lhe devotar afeição. É o chamado gigolô. Já o rufião ativo, é aquele que cobra tributo da prostituta, a título de proteção, ou meio de coação pura e simples. É o chamado cafetão ${ }^{47}$ (HUNGRIA, 1981, p. 281). Nota-se que o crime de rufianismo busca disciplinar a vida sexual de acordo com os bons costumes, e não proteger o patrimônio da prostituta contra a apropriação da sua renda por parte do rufião, até

\footnotetext{
${ }^{45}$ Hungria faz mais do que isso, pois indica que a ideia da inevitabilidade da prostituição já está presente nas narrativas moralistas desde a Antiguidade Clássica, como nas obras de Cato e Agostinho, e, já na Idade Média, na doutrina de Tomás de Aquino (Hungria, 1981, p. 261).

${ }^{46}$ É também chamado de lenão, e a sua atividade de lenocínio.

${ }^{47}$ No século XIX e, ao menos, na primeira metade do século XX, a palavra cafetão ou, na época, caftans, designava um grupo específico, e não uma atividade determinada. Segundo Soares, no final do século XIX, "a importação das prostitutas europeias, sobretudo daquelas provenientes dos países da Europa Centro-Oriental (Polônia, Rússia, Alemanha, ÁustriaHungria etc.), era organizado pelos "cafetens", quase todos de origem judaica, que exploravam as prostitutas e à prostituição, obtendo avultados lucros e fomentando o tráfico das "escravas brancas". (...). Estes caftens recrutavam mulheres para a prostituição nas comunidades judaicas da Europa Centro-Oriental. (...). O embarque para o Rio de Janeiro dava-se no porto de Marselha, que era "o ponto de marcha de todos os caftens. Inclusive, havia nesta cidade do sul da França um mercado de compra e venda dessas mulheres, organizado pelos próprios "caftens" que agiam em diversas partes do mundo. (...). Era também muito comum entre os "caftens" a prática do "casamento" com várias mulheres a eles subordinadas e por eles exploradas. (...) (SOARES, 1992, p. 57-58). Escrevendo em meados do século XX, Hungria relata a continuidade dessa mesma dinâmica (HUNGRIA, 1955, p. 285-286)
} 
porque há crime ainda que a iniciativa de sustento parta do profissional do sexo (JESUS, 1999, p. 165$)^{48}$.

Essa classificação está estampada no Código Penal brasileiro, até porque Hungria foi um dos seus autores. Nessa lei, a atividade da prostituta não é criminalizada, mas muitas das atividades a ela associadas o são, como aquelas do proxeneta, do traficante de mulheres e do rufião. Por exemplo, o crime de induzir ou atrair alguém à prostituição ou outra forma de exploração sexual, facilitá-la, impedir ou dificultar que alguém a abandone está previsto no art. 228 do Código Penal; a conduta do rufião de tirar proveito da prostituição alheia, participando diretamente de seus lucros ou fazendo-se sustentar, no art. 230 da mesma lei; e o de promover a entrada, no território nacional, de alguém que nele venha a exercer a prostituição, ou a saída de alguém que vá exercê-la no estrangeiro, ou ainda o seu deslocamento dentro do território nacional com os mesmos fins nos arts. 231 e 232 do Código Penal. Note-se que a lei brasileira atual, apesar de punir diversas atividades subjacentes à prostituição, não criminaliza o seu cliente.

Mas nem sempre foi assim. Na época colonial, sob as Ordenações Filipinas ${ }^{49}$, a própria prostituição era tida como crime. Todavia, com a Proclamação da Independência e a edição do Código Penal Imperial de 1830, deixaram de ser crime tanto a prostituição quanto as suas atividades acessórias, como a do proxeneta e do rufião. Somente com a República, e adoção do Código Penal de 1890, é que as condutas acessórias à prostituição, mas não a própria prostituição em si, voltaram a ser criminalizados, sob a rubrica "Crimes contra a Segurança da Honra e Honestidade das Famílias e do Ultraje Público ao Pudor" (FRANCO, 2007, p. 1114).

E o que aconteceu nos 60 anos que transcorreram entre 1830 e 1890, para que o legislador mudar de posição de maneira tão radical? Foi a chegada às terras brasileiras do pensamento higienista e da criminologia positivista, tratada anteriormente. E, como se viu, essa orientação foi mantida no Código Penal de 1940, a atual lei vigente, de forte influência positivista, como se extrai das palavras de Hungria.

Assentado esse ponto, verifica-se que o crime de casa de prostituição traz um problema interessante. $\mathrm{Na}$ sua redação original, o art. 229 do Código Penal assim o definia "casa de

\footnotetext{
${ }^{48} \mathrm{O}$ crime de rufianismo alcança inclusive a conduta dos pais que sejam sustentados por sua filha prostituta. Trata-se inclusive de forma mais grave de tal crime (art. 230, $\$ 1^{\circ}$, do Código Penal).

${ }^{49}$ As Ordenações Filipinas é uma compilação de leis, elaborada no século XVI durante a época da União Ibérica, a reunião das coroas espanhola e portuguesa sob o controle do Rei da Espanha. Após Portugal retomar a sua independência, as Ordenações Filipinas foram confirmadas como base do ordenamento jurídico do Reino de Portugal e de suas colônias, como o Brasil. Ao longo dos séculos ele foi muito modificado, mas, no Brasil, foi somente com a Independência que ele foi paulatinamente substituído por novas leis e códigos. Por exemplo, o Direito Civil brasileiro, que cuida da relação entre particulares, foi regido pelas Ordenações Filipinas até o 1916, quando foi editado o primeiro Código Civil brasileiro.
} 
prostituição: manter, por conta própria ou de terceiro, casa de prostituição ou lugar destinado a encontros para fim libidinoso, haja, ou não, intuito de lucro ou mediação direta do proprietário ou gerente". Ou seja, seguida a literalidade da lei, praticariam tal crime tanto o dono de motel quanto o sujeito que, com habitualidade, empresta a casa para que amigos mantenham encontros sexuais clandestinos. Diante disso, desde o início da vigência dessa lei, houve esforços para a mitigação de seu rigor. Hungria relata que, na época que escrevia os seus Comentários, parte dos juristas exigia, para a caracterização desse crime, que o dono do local tivesse mediado diretamente o encontro sexual, embora a lei não fizesse tal exigência (HUNGRIA, 1981, p. 279).

A incerteza sobre o que seria ou não crime contribui para que, na prática, os governantes, ao longo das décadas, tivessem um amplo espaço de discricionariedade para levar a cabo suas políticas acerca da prostituição, ora ignorando bordéis e estabelecimentos congêneres - como as pousadas que aceitam que prostitutas utilizem os seus quartos para a sua atividade profissional -, ora conduzindo intensa persecução contra tais empreendimentos. Assim, a forma como tal crime é tratado em determinado momento e local é um excelente termômetro, para a forma como, naquele contexto, a prostituição é representada socialmente e politicamente pelas autoridades.

Tal situação, contudo, não se alterou muito com o advento da Lei 12.015/2009, que modificou a redação do crime de casa de prostituição para a seguinte: "manter, por conta própria ou de terceiro, estabelecimento em que ocorra exploração sexual, haja, ou não, intuito de lucro ou mediação direta do proprietário ou gerente". Com isso, excluiu-se a possibilidade de enquadramento nessa categoria de crime de estabelecimento como motéis, que, grosso modo, não se dedicam a fornecer lugar, para a prática de prostituição. Mas como ficam as pessoas que alugam apartamentos para a prostituição, conscientes dessa situação? Decerto os bordéis e as pousadas continuaram dentro do seu âmbito de criminalização, e a sua persecução continuou intermitente, e dependente dos humores dos governantes ${ }^{50}$.

\footnotetext{
${ }^{50}$ A título de exemplo, pode-se mencionar a Operação Puritaten (pureza, em latim), deflagrada pela Polícia Militar do Distrito Federal no primeiro semestre de 2013, na Asa Norte de Brasília. A operação foi deflagrada em razão do assassinato da prostituta Raquel Nascimento, de 26 anos, em uma quitinete comercial na mesma região da cidade. No total, foram fechadas 11 pousadas na região das quadras 700 na Asa Norte, sob a alegação que elas favoreceriam a prostituição e o tráfico de drogas. Mostra-se interessante ainda que a expressão "pureza" tenha sido escolhida para uma operação policial de combate à prostituição. Isso diz muito acerca das representações policiais que, ainda hoje, cercam a ideia de prostituição. Informação extraída de reportagem do Correio Braziliense, acessada em 10/09/2016, http://www.correiobraziliense.com.br/app/noticia/cidades/2013/05/04/interna_cidadesdf,364254/pousadas-interditadas-naasa-norte-serviam-para-a-prostituicao.shtml
} 
Hungria escreveu seus "Comentários" em meados do século XX, e nele o ideário higienista continuava forte e vigente, ao menos entre os juristas. Todavia, já à beira do século XXI, essa narrativa parece ter permanecido, cristalizando-se no imaginário social.

Em seu livro "Direito Penal, v. 3", cuja 14 edição consultada, data de 1999, o jurista Damásio de Jesus sustentava que a prostituição era uma fatalidade e motivo de relevante inquietação social, mas que não poderia ser criminalizada por não atingir bens jurídicos de outras pessoas ${ }^{51}$. Todavia, ele ainda considera legítima a criminalização das condutas subjacentes à prostituição, por violar a "disciplina da vida sexual de acordo com os bons costumes, a moralidade pública e a organização da família” (JESUS, 1999, p. 151). Mostra-se evidente, nessa passagem, a retomada da narrativa moralista, para a criminalização das condutas em exame.

Por vezes, esse viés apresenta-se de forma mais sutil, mas ainda sim, inequívoca. O jurista Régis Prado afirma que os tipos mencionados pretendem "tutelar a liberdade sexual das pessoas, inclusive a sua integridade e autonomia sexual, como o interesse precípuo de evitar o fomento e a proliferação da prostituição, bem como a corrupção moral que gravita em torna torno dela" (PRADO, 2006, p. 259). A referência simultânea do autor à autonomia sexual e à necessidade de evitar a proliferação da prostituição é confusa. Entenderia ele que a finalidade dos referidos crimes seria ajudar a prostituta a se salvar de si mesma? Não há clareza.

De todo modo, fica claro no entendimento dos dois juristas mencionados que, ao ser deixado para trás o discurso médico-policial, ganha força a narrativa moralista, ainda que, por vezes, com uma roupagem paternalista.

Esse recuo do discurso higienista-policial, em especial no que tange à criminalidade em geral, deveu-se, ao menos em parte, ao desenvolvimento da Sociologia, principalmente nos Estados Unidos. Suas proposições foram sendo uma a uma refutadas numa sequência histórica de achados sociológicos, que vão desde o condicionamento social da criminalidade até a relativa arbitrariedade da rotulação de determinadas condutas como crimes, passando pela descoberta de que os ricos praticam sim crimes. Como explicar, nesse contexto, a criminalidade com base num atavismo, como fazia Lombroso? Todavia, nenhuma narrativa teve força para assumir o lugar hegemônico anteriormente ocupado pela narrativa médicapolicial (ZAFFARONI e BATISTA, 2003, p. 286). Daí, por exemplo, o ressurgimento da narrativa moral para justificar a criminalização das atividades acessórias à prostituição, como

\footnotetext{
${ }^{51}$ Eis um grande problema de coerência no sistema jurídico, porque o moderno Direito Penal é regido pelo chamado princípio da lesividade. Segundo esse princípio, somente poderá ser caracterizada como crime a conduta que transcender a esfera pessoal do agente, e atingir o bem jurídico de outra pessoa, como a vida, o patrimônio ou a liberdade sexual.
} 
em Damásio de Jesus e Régis Prado. Mas essa narrativa moralista não é a única a disputar o tratamento legal da prostituição.

A narrativa dos direitos humanos, de igualdade de direito e do combate à discriminação é uma das novas vertentes, cuja importância dentro do Sistema de Justiça parece ser cada vez mais intensa. A ideia de que o ser humano seria dotado de uma dignidade própria, que deveria ser especialmente valorizada pelo ordenamento jurídico, conduziu ao reconhecimento de inúmeros direitos e ao afastamento de inúmeros antigos preconceitos, incompatíveis com essa nova perspectiva.

A força dessa nova vertente pode ser observada, exemplificativamente, na decisão judicial abaixo transcrita. No passado, com base no art. $405, \S 3^{\circ}$, II, do Código de Processo Civil de 1973, que dizia que não poderia ser testemunha aquele "que, pelos seus costumes, não for digno de fé”, não era admitido o testemunho das prostitutas em causas cíveis. Tal era o costume desde as Ordenações Filipinas. Todavia, a decisão abaixo sinaliza uma mudança na visão das Cortes de Justiça hoje mudou:

\footnotetext{
RESP - PROCESSO PENAL - TESTEMUNHA - HOMOSSEXUAL - A história das provas orais evidencia evolução, no sentido de superar preconceito com algumas pessoas. Durante muito tempo, recusou-se credibilidade ao escravo, estrangeiro, preso, prostituta. Projeção, sem dúvida, de distinção social. Os romanos distinguiam - patrícios e plebeus. A economia rural, entre o senhor do engenho e o cortador da cana, o proprietário da fazenda de café e quem se encarregasse da colheita. Os Direitos Humanos buscam afastar distinção. O Poder Judiciário precisa ficar atento para não transformar essas distinções em coisa julgada. O requisito moderno para uma pessoa ser testemunha é não evidenciar interesse no desfecho do processo. Isenção, pois. O homossexual, nessa linha, não pode receber restrições. Tem o direito-dever de ser testemunha. E mais: sua palavra merecer o mesmo crédito do heterossexual. Assim se concretiza o princípio da igualdade, registrado na Constituição da República e no Pacto de San Jose de Costa Rica. (Resp. 154.857/DF, Rel. Ministro LUIZ VICENTE CERNICCHIARO, SEXTA TURMA, julgado em 26/05/1998, DJ 26/10/1998, p. 169)
}

Os movimentos feministas trazem outra nova narrativa acerca da prostituição, que contribuiu não só para a edição da Lei Maria da Penha ou para a criação de um crime autônomo de feminicídio, como foi fundamental na formatação da Lei 12.015/09 - já mencionada acima no contexto do exame do crime de casa de prostituição -, pois, entre outras inovações, modificou o nome jurídico do crime de "tráfico de mulheres" para "tráfico de 
pessoas", demonstrado uma mudança de perspectiva, uma vez que não apenas mulheres possam ser vítimas do crime de tráfico de seres humanos, mas qualquer gênero de pessoa.

Outra tendência, de viés liberal, busca a descriminalização de todas essas condutas, pois não basta que uma conduta seja considerada imoral para que ela possa ser considerada como crime, pois é indispensável ainda que essa conduta faça mal a outrem, segundo o princípio da lesividade, basilar em qualquer sistema penal democrático. Dessa perspectiva, as condutas relacionadas, por não violarem a autodeterminação sexual, ou utilizarem de violência ou grave ameaça, não poderiam ser consideradas como crime (FRANCO, 2007, p. 1115). Essa última concepção enxerga a prostituição como uma manifestação da autodeterminação sexual da pessoa, e, portanto, nem ela e nem as suas atividades subjacentes poderiam ser criminalizadas.

Essas e outras narrativas surgiram nas últimas décadas para tratar do regime de verdades (ou de versões) acerca da prostituição. No entanto, as antigas ainda permanecem cristalizadas no imaginário social.

Para melhor compreender o influxo dessas novas narrativas, é necessário, porém, entender os movimentos dentro da Sociologia, que conduziram à perda da força hegemônica da narrativa da criminologia positivista, e ao nascimento de novas visões acerca da prostituição, do feminino e do corpo, ao menos no âmbito da academia.

\subsection{Narrativa sociológica}

O surgimento e o desenvolvimento da chamada Escola de Chicago contribuiu significativamente para o fim da hegemonia da criminologia positivista ${ }^{52}$.

A intenção não é traçar um histórico das ideias da Escola de Chicago, ou mesmo indicar, ponto-a-ponto, de que forma elas se contrapunham às teses da criminologia positivista. Basta ressaltar que, desde início, a Escola de Chicago concentrou-se nas condicionantes ambientais e sociais da criminalidade, o que, por si só, se contrapõe ao enfoque no indivíduo da criminologia positivista.

Ressalte-se que, ao contrário da criminologia positivista, as diversas teorias da Escola de Chicago não foram apropriadas como narrativa justificadora do poder punitivo estatal. Em

\footnotetext{
${ }^{52}$ HASSEMER e CONDE realçam a importância da Escola de Chicago para as pesquisas destinadas à observação dos espaços urbanos e dos "defeitos" do processo de socialização. "La importancia de la Escuela de Chicago radica sobre todo en haber destacado do contexto social urbano en el que surge la delincuencia, principalmente juvenil, ubicándola geográficamente en determinadas zonas de la ciudad, lo que naturalmente permite una mejor observación de la misma." (HASSEMER \& CONDE, 2001, p.84).
} 
razão disso, como visto acima, a criminologia positiva teve uma sobrevida no âmbito do Direito Penal, mas, por fim, perdeu o seu protagonismo, dando lugar a uma crise de legitimação do poder punitivo estatal e ao surgimento de uma pluralidade de narrativas buscando ocupar esse vazio, sem que qualquer delas tenha alcançado hegemonia (ZAFFARONI e BATISTA, 2003, p. 286).

Dito isso, entre as diversas teorias que integram a chamada Escola de Chicago, para o presente trabalho, convém destacar aquelas que, na mesma toada da teoria das representações sociais, apresentada anteriormente, buscaram entender como os sujeitos eram considerados e rotulados pelo coletivo. Essa corrente deu origem ao que se convencionou chamar de sociologia do desvio ${ }^{53}$.

Bruxa, impura, portadora de doenças, imoral e criminosa foram rótulos até então atribuídos à prostituta, cristalizados por meio das representações sociais nas narrativas moral, religiosa, médica e jurídica, conforme já abordado. Coube, então, à sociologia do desvio analisar como são atribuídos esses rótulos e quem são aqueles escolhidos a recebê-los.

Erving Goffman e Howard Becker são grandes nomes da perspectiva de uma corrente da sociologia do desvio denominada teoria do etiquetamento ou labelling approach, o qual leva em conta, basicamente, que as interações sociais geram reações, percepções, conceitos e símbolos, e que a classificação de um comportamento como desviante não depende do ato materialmente em si, mas da reação social a ele. "O desvio não é uma qualidade do ato que a pessoa comete, mas uma consequência da aplicação por outros de regras e sanções a um 'infrator'. O desviante é alguém a quem esse rótulo foi aplicado com sucesso; o comportamento desviante é aquele que as pessoas rotulam como tal", na famosa definição de Becker (2008, p. 22).

O sociólogo norte-americano considera que quem define o que é o desvio ou quem é a pessoa desviante não é o ato ou a conduta praticada pela pessoa, mas a reação dos outros diante dessa conduta, a qual acarreta, ou não, na aplicação de regras ou sanções ao infrator. Aliás, essa reação pode ser completamente independente da conduta infratora, e, portanto, uma pessoa pode ser considerada como desviante mesmo sem ter cometido qualquer ato infrator, tendo como base apenas seu estilo de vida.

\footnotetext{
${ }^{53}$ Os primeiros estudos acerca da sociologia do desvio remontam ao final do século XIX, sendo desenvolvidos por autores anglo-saxões, aparecendo primeiramente como uma disciplina que tinha por finalidade a conceituação de alguns problemas sociais abordados pelas obras de criminologia, tratados filosóficos e ensaios religiosos (LIMA, 2001, p. 2). Todavia, o maior impulso dado à sociologia do desvio veio no início do século XX, por meio do departamento de sociologia da Universidade de Chicago, o qual se dedicava aos estudos em antropologia urbana, criminalidade e desvio.
} 
A partir da mesma ideia central de desvio como reação dos outros a um comportamento ou conduta infratora, chega-se também à conclusão de que o conceito do termo desviante, também não dependente da própria autoimagem da pessoa como tal, mas sim de uma aplicação com sucesso desse rótulo ${ }^{54}$.

Como se viu, a atividade de prostituição, desde há muito tempo, foi considerada como uma conduta desviante por parte da sociedade, sob as mais diversas justificativas, uma vez que os profissionais do sexo são tidos como pessoas abjetas, violadoras da expectativa social de conduta que é reservada a um cidadão exemplar. No entanto, a sociologia do desvio permite enxergar a figura da prostituta como um rótulo, construído socialmente, que é aplicado pela sociedade a pessoas específicas de acordo com regras determinadas. Ademais, a imposição desse rótulo implica a imposição também de uma série de características adjacentes, como inferioridade moral, periculosidade e sujeira. Nesse contexto, e a título de exemplo, uma mulher que mantém relacionamento sexuais com homens socialmente bemposicionados, em troca de presente, como joias, carros e viagens, não é vista, regra geral, como prostituta, porque não foram preenchidos os requisitos para a imposição do rótulo.

O estudo do desvio como uma construção social, e não como uma qualidade da própria conduta considerada, não ficou restrito à Escola de Chicago. É precisamente essa perspectiva que foi adotada por Foucault, ao estudar a sexualidade e os mecanismos de poder e controle sobre o corpo. São temas indispensáveis, para compreender as novas narrativas que têm sido construídas no âmbito acadêmico acerca da prostituição, uma vez ela está estreitamente relacionada com as representações sociais vigentes acerca da sexualidade e do corpo, especialmente do corpo feminino.

Na obra "A história da sexualidade", ele sintetizou os elementos desse dispositivo: 1) operabilidade por meio de técnicas móveis, poliformas e conjunturais de poder; 2) promove formas de controle e comportamento social; 3) refere-se às sensações do corpo, à qualidade dos prazeres, à natureza das impressões; 4) ligação com a economia por meio da ideia do corpo. Dessa forma, para Foucault, o dispositivo da sexualidade tem como principal função estratégica a "penetração e o controle do corpo individual e social". (CASTRO, 2009, p. 401).

\footnotetext{
${ }^{54}$ BECKER (2008) ainda sistematiza os quatro possíveis tipos de desvio, conforme a relação entre a ideia da reação dos outros e a prática efetiva do ato considerado desviante. Assim, têm-se: 1) aquele que pratica um ato desviante e é percebido como tal (desviante puro); 2) aquele que pratica um ato desviante e não é percebido como tal (desviante secreto); 3) aquele que age conforme as regras e não é percebido como desviante (comportamento apropriado); e 4) aquele que age conforme as regras e é percebido como desviante (falsamente acusado). Nessa classificação, a prostituta poderia ser enquadrada como desviante puro ou desviante secreto, a depender do reconhecimento como tal. Mas tal classificação não apresenta qualquer relevância, por si só, com a vinculação, ou não, da prostituição com a criminalidade.
} 
Assentado esse ponto, verifica-se que, no âmbito das representações sociais, o termo prostituição remete à ideia primordial de "venda do corpo", "sexo por dinheiro", "venda do desejo", "venda do prazer", e isso a partir de qualquer das perspectivas examinadas (social, cultural, biológica, jurídica etc.). Assim, têm-se que os dois elementos básicos da ideia de prostituição são: comercialização (ou dinheiro) e corpo. Ambos serão esmiuçados adiante, considerando a teorização do dispositivo de controle do corpo acima exposta.

O corpo "continua a ser um ponto cego conceitual, tanto no pensamento filosófico ocidental dominante quanto na teoria feminista contemporânea" (ELIZABETH GROSZ, 2000, p. 47). Entende-se ponto cego como algo que é objeto de inúmeras controvérsias e inconsistências conceituais. No entanto, apesar disso, o corpo é também um lugar de inscrições, produções ou constituições sociais, políticas, culturais e geográficas (GROSZ, 2000, p. 84). O corpo foi e ainda é receptáculo da interação de todos esses elementos, em especial no âmbito da prostituição. Assim, a ideia da "venda do corpo" carrega uma densidade de significantes e significados, que (inter)agem em torno de uma esfera de poder ${ }^{55}$.

Talvez, exatamente por receber o corpo toda essa carga significativa, é que as representações sociais sobre a prostituição concentram-se, historicamente e de modo automático, na ideia de “corpo feminino”. Afinal, falar de prostituição é afetar diretamente o dispositivo de sexualidade, que envolve a estimulação dos corpos e dos sentidos, a intensificação dos prazeres, reforços de controles e resistências, contornados por grandes estratégias de saber e poder.

Além disso, como bem tratou Foucault, o dispositivo de sexualidade relaciona-se intrinsecamente com o que ele denomina de dispositivo de aliança, o qual, segundo ele, envolve "sistema de matrimônio, de fixação e desenvolvimento dos parentescos, de transmissão dos nomes e bens", de forma que ele se estrutura em razão de "um sistema de regras que define o permitido e o proibido, o prescrito e o ilícito, o objetivo de reprodução, manter a lei que o rege" (FOUCAULT, 1998, p. 100). O dispositivo de sexualidade, por sua vez, se relacionaria ao prazer, sendo o corpo seu principal mecanismo de articulações sutis, que o produz e o consome.

Historicamente, o dispositivo da aliança dominou o da sexualidade, pois, aliado à tradição e a transmissão de patrimônio, reprimiu a ideia de prazer e suas articulações. A ideia

\footnotetext{
${ }^{55}$ Nesse sentido, Foucault sobre a construção do dispositivo de sexualidade: "A sexualidade é o nome que se pode dar a um dispositivo histórico: não à realidade subterrânea que se apreende com dificuldade, mas à grande rede da superfície em que a estimulação dos corpos, a intensificação dos prazeres, a incitação ao discurso, a formação dos conhecimentos, o reforço dos controles e das resistências, encadeiam-se uns aos outros, segundo algumas grandes estratégias de saber e de poder". (FOUCAULT, 2005, p. 100).
} 
de família e do controle da reprodução por meio de um estatuto definido de sexualidade reforçou o dispositivo de aliança, tornando proibido tudo aquilo que o ameaçasse. ${ }^{56}$

Dessa forma, a prostituição, que se liga à ideia da comercialização do sexo transitório, constitui uma representação de desvio e uma ameaça aos padrões reprodutivos da instituição familiar e da transmissão legítima de patrimônio, sendo, portanto, rotulada como um ato ilícito e imoral no que tange à figura feminina.

Contudo, ao mesmo tempo em que a prostituição é tida como um desvio, ameaçador da ordem familiar, ela também é considerada como um mal necessário, seja para proteger a castidade das mulheres de "bem" (SIMMEL, 2006, p. 9) ${ }^{57}$, para suprir uma "defasagem temporal entre o início da maturidade sexual e a maturidade intelectual, econômica e psicológica do homem" (SIMMEL, 2006, p.7) ${ }^{58}$, seja até mesmo para preservar o casamento das pulsões poligâmicas do homem (SIMMEL, 2006, p. 11) ${ }^{59}$.

Essa perspectiva de "mal necessário" da atividade de prostituição à sociedade patriarcal pode muito bem ser assemelhada à ideia de trabalho sujo, desenvolvida por Everett Hughes $^{60}$, ao tratar da execução de milhares de vítimas em campos de extermínios pelos agentes da Guarda Especial nazista (Schutzstaffel ou SS, em alemão) que trabalham na "Solução Final” proposta pelo então governo alemão. Hughes alerta que a ideia de "trabalho sujo" realizado pelos agentes da polícia nazista pode ser transposta para vários temas sociais, principalmente quando se trata de um grupo marginalizado e submetido ao estigma:

E finalmente não é injusto dizer que os agentes estavam pelo menos trabalhando na direção dos desejos de muitas pessoas, embora eles pudessem ter boas intenções na maioria das vezes. As mesmas questões podem ser feitas sobre nossa própria sociedade, e com referência não apenas aos prisioneiros, mas também a muitos

\footnotetext{
${ }^{56}$ Nesse sentido, CAPELA em sua dissertação "O direito à prostituição: aspectos de cidadania": "A ideia social em torno do que é a prostituição traz a tona uma contraposição ao casamento. Não por acaso, nos séculos XVIII, XIX e até início do século XX, havia uma contraposição entre a mulher pública e a mulher honesta. A mulher honesta era aquela que permanecia em casa, que contrai matrimônio, que corresponde às investidas de seu marido e que se estrutura para criar e cuidar da família. A mulher pública é a que vive fora de casa, a que pejorativamente era tida como independente (porque não tinha laços familiares que a condicionava, apesar de existirem, claramente, outros laços sociais que igualmente a condicionava) e, sobretudo, a que se relacionava sexualmente com homens utilizando de outro tipo de contrato. Menos exclusivo e normalmente menos duradouro. A mulher pública era apelido para o que hoje chamamos de prostituta." (CAPELA, 2013).

57 "Por que, então, não sacrificaria alguns milhares de moças para possibilitar aos homens não casados uma vida sexual normal e proteger assim a castidade das outras mulheres?" (SIMMEL, 2006, p. 9).

58 "A necessidade da prostituição nas culturas de nível mais elevado baseia-se na defasagem temporal entre o início da maturidade sexual e a maturidade intelectual, econômica e psicologia do homem. Porque esta última, com razão, é exigida antes que a sociedade autorize o homem a fundar seu próprio lar.” (SIMMEL, 2006, p. 7).

59 "Ora, dado que as impulsões poligâmicas se encontram na natureza masculina, o casamento monogâmico exige, inclusive depois da supressão de todas as dificuldades econômicas e visto unicamente como uma instituição erótico-moral, um tipo de homem que tenha tido a oportunidade de se examinar e se conhecer, não um adolescente em flor, ainda que, por certo, nele também se agitem em plena força as pulsões carnais. Se, de um lado, não se pode autorizar este último a ligar-se a uma mulher para o resto da vida, de outro não se poderia recusar-lhe a expressão de seus instintos naturais". (SIMMEL, 2006, p. $11)$.

${ }^{60}$ Também um pesquisador do que foi chamado de Escola de Chicago, Everett Hughes abordou a questão do trabalho sujo ao tratar da execução de milhares de vítimas em campos de extermínios pelos agentes da Guarda Especial do Nazismo que trabalham na "Solução Final" proposta pelo então governo alemão.
} 
grupos contra os quais são ilegais ou há estigma. E eu não tenho as respostas. Eu deixo você pesquisá-las. (HUGHES, 1993, p. 95) (tradução livre) $)^{61}$

De acordo com essa narrativa, pode-se dizer que a prostituição seria um mal necessário à existência da própria sociedade patriarcal ${ }^{62}$, da dominação do masculino sobre o feminino, em nível físico, intelectual e cultural, que leva à ideia da submissão da sexualidade feminina a masculina A relação sexual ou mesmo a existência da própria fêmea/mulher existiria para a satisfação do macho/homem. E como o corpo é o principal mecanismo de expressividade do dispositivo da sexualidade, a expressão "corpo feminino" recebe ainda mais uma rede de significantes e significados. Tanto é assim que, como foi visto, se considerava normal separar um grupo de mulheres para viver em uma situação tida como degradante, com o objetivo de satisfazer hipotéticas necessidades biológicas masculinas, tanto num cabaré em Paris quanto em um harém em Bagdá. Contudo, essa expressão "corpo feminino" deve ser cindida a fim de se identificar a própria carga individual de significantes entre o "corpo" e o "feminino".

A ideia de corpo, geralmente, liga-se às oposições quase automáticas de mente/corpo, razão/paixão, profundidade/superficialidade, sensatez/sensibilidade, dentro/fora, ser/outro, realidade/aparência, vitalismo/mecanicismo, as quais estão bastante arraigadas na tradição filosófica, desde os pré-socráticos até a modernidade ${ }^{63}$. Mais importante é a correlação entre os binômios mente/corpo e homem/mulher, de modo a associar a mente com o homem, e o corpo com a mulher no âmbito das representações sociais (GROSZ, 2000, p. 49). Assim, o corpo seria um processo, um receptáculo de significantes, um objeto político, social e cultural.

A partir dessa perspectiva, é possível ampliar as noções do dispositivo de sexualidade, uma vez que ele é produzido principalmente por meio de discursos (MISKOLCI, 2009, p. 153), para explorar outras potencialidades de expressão do corpo, outras formas de prazer,

\footnotetext{
61 "It is, finally, not unjust to say that the agents were at least working in the direction of the wishes of many people, although they may have gone beyond the wishes of most. The same questions can be asked about our own society, and with reference not only to prisoners but also to many other groups upon whom there is no legal or moral stigma. Again I have not the answers. I leave you to search for them" (HUGHES, 1993, p. 95).

62 "Não há ilusão alguma a se ter: enquanto o casamento existir, a prostituição também existirá. É só como amor plenamente livre, quando caducar a oposição entre legitimidade e ilegitimidade, que não se precisará mais de pessoas especiais dedicada à satisfação sexual do gênero masculino" (SIMMEL, 2006, p. 10).

${ }^{63}$ Os significados da relação mente/corpo ao longo da história foram recuperados por Elizabeth Grosz, apresentando-os em três etapas. A primeira, referente à Antiguidade Clássica, quando havia uma profunda desvalorização do corpo (somatofobia), constituindo ele um impedimento do conhecimento. A segunda, representada pela filosofia de René Descartes, que, ao fundamentar a divisão entre alma/natureza, reforçou ainda mais o distanciamento e desprivilegio do corpo em relação à mente. E, finalmente, a terceira, inaugurada pela filosofia de Benedictus de Spinoza, ao considerar a noção de uma substância absoluta e infinita, que não é divisível a dualismos, de forma que a substância infinita, no caso Deus, poderia se manifestar em forma de pensamento e de corpo.
} 
como a homossexualidade, para além dos padrões tradicionais, da heteronormatividade ${ }^{64}$ e da dicotomia masculino/feminino.

Trilhando esse mesmo caminho também é possível admitir a desvinculação da prostituição ao corpo feminino e ampliá-la a todos os corpos, sejam quais forem as diferenças de classe, raciais e de "sexos", adotando-se uma perspectiva das teorias queer, na qual, "o sistema moderno da sexualidade passou a ser encarado com um conjunto de saberes e práticas que estrutura toda a vida institucional e cultural do nosso tempo" (MISKOLCI,2009, p. 169).

Os teóricos queer focaram na análise dos discursos produtores de saberes sexuais por meio de um método desconstrutivista. Ao invés de priorizar investigações sobre a construção social de identidades, estudos empíricos sobre comportamentos sexuais que levem a classificá-los ou compreendê-los, os empreendimentos queer partem de uma desconfiança com relação aos sujeitos sexuais como estáveis e foca nos processos sociais classificatórios, hierarquizadores, em suma, nas estratégias sociais normalizadoras dos comportamentos. Ao colocar em xeque as coerências e estabilidades que, no modelo construtivista, fornecem um quadro compreensível e padronizado da sexualidade, o queer revela um olhar mais afiado para os processos sociais normalizadores que criam classificações, que, por sua vez, geram a ilusão de sujeitos estáveis, identidades sociais e comportamentos coerentes e regulares (MISKOLCI, 2009, p.169).

Contudo, por mais que essas teorias contemporâneas ampliem o dispositivo de sexualidade, de corpo, de prazer e de prostituição, a ideia de "venda do corpo" ainda está fortemente imbricada dos construtos de moralidade, proibição e ilicitude e principalmente com a ideia de corpo feminino.

O imaginário comum social da prostituição de rua é uma mulher, com roupas provocantes, na calçada à espera de clientes. Mesmo que esse corpo biologicamente seja masculino, sua aparência assume, na grande maioria dos casos, formas femininas e, portanto, remete às representações sociais da venda do corpo sensual, feminino. Assim, não apenas por isso, mas também pelo limite temporal, a pesquisa dedicou-se a analisar a prostituição na avenida W3 norte sob o aspecto do feminino, independentemente, se essa figura possuísse um genótipo masculino.

Esclarecido esse recorte da pesquisa, passa-se a outro elemento importante na ideia de prostituição, a necessidade de se considerar uma separação fundamental entre atos de desejo,

\footnotetext{
${ }^{64}$ A heteronormatividade seria a prevalência do padrão masculino/feminino nas relações homossexuais. "Um exemplo é o de gays, que costumam reproduzir em suas relações, dicotomias derivadas de uma concepção heterossexista daí a díade ativo/passivo que toma como referência uma relação heterossexual reprodutiva para definir e hierarquizar posições sexuais." (MISKOLCI, 2009, p. 153).
} 
atos de sexo, atividade erótica, atividade afetiva e vida econômica. Nesse aspecto da objetivação das relações afetivas, insere-se a análise do segundo elemento da ideia de prostituição, a ideia da compra, de comercialização do corpo.

No mercado do sexo, pode-se incluir não apenas a atividade de prostituição, mas também o strip-tease, o modelo fotográfico pornográfico, as danças eróticas ou o mesmo sexo por telefone. Enfim, "providenciar serviços sexuais em troca de dinheiro ou seu equivalente" (BLANCHTTE, SILVA e CAMARGO, 2016, p. 146).

Por outro lado, teóricos feministas contemporâneos questionam a natureza "objetiva" da atividade de prostituição, se se trataria apenas de prestação de serviços sexuais ou se abarcaria outro tipo de serviço que pudesse envolver até certa afetividade, tanto por parte do profissional quanto por parte do cliente, no que diz respeito à satisfação de fantasias do cliente ou até mesmo a satisfação profissional da praticante da prostituição (OLIVAR, 2011; SCOULAR, 2010). Ora, se se trataria de uma prestação de serviço como qualquer outra, não poderia seu prestador ter satisfação profissional, ou mesmo prazer, ou ainda orgulho, em realizar esse tipo de atividade laborativa?

A percepção da atividade de prostituição como algo mais amplo que a simples prática de sexo proporciona uma interpretação ainda mais abrangente para o mero negócio da "venda do corpo", no qual o corpo teria significado muito maior que o aspecto físico. Nesse sentido, a ideia de superação do dualismo entre mente/corpo, proposta por Elizabeth Grosz, do corpo como um processo, no qual ele é "objeto de sistemas de coerção social, inscrição legal, trocas sexuais e econômicas", propõe a consideração do corpo mais como uma construção cultural da subjetividade do que pelos materiais com os quais tal construção é feita.

A prestação de um serviço de forma objetiva remete à ideia de uma atividade profissional, disponível a um número indeterminado de pessoas, um mercado do prazer, que é potencializado no contexto urbano. Segundo Georg Simmel, a metrópole sempre foi o centro da economia monetária, "nela a multiplicidade e a concentração da troca econômica dão uma importância aos meios de troca que a fragilidade do comércio rural não teria permitido" (SIMMEL, 1973, p. 13).

É exatamente na cidade, onde as relações subjetivas se tornam objetivas pela intensidade de estímulos externos e internos e pela cultura impessoal promovida pelas trocas monetárias, que foi possível desenvolver/intensificar a atividade de prostituição como uma mercadoria, com valor monetário, um serviço à disposição de indeterminadas pessoas ${ }^{65}$.

65 "Na esfera da psicologia econômica do pequeno grupo, é importante que, sob condições primitivas, a produção sirva ao cliente que solicita a mercadoria, de modo que o produtor e o consumidor se conheçam. A metrópole moderna, entretanto, é 
Contudo, também é na cidade que se pode observar espacialmente e também simbolicamente a objetificação da atividade de prostituição ou sua "situa-ação" no contexto social. Basta observar o local destinado à prática da prostituição nos grandes centros urbanos, o qual, como lembra Margareth Rago (1991, p. 23), é "associado à sujeira, a esgoto, podridão, em suma, daquele que constitui uma dimensão rejeitável na sociedade".

As ideias de segregação e abjeção (o ato de jogar para fora) caminham juntas simbolicamente em todos os níveis da normatividade, seja espacial, cultural, social ou jurídica. Assim, além de atividade de prostituição ser segregada e abjeta na vida da cidade ela também o é do ordenamento jurídico, que apesar da atividade não ser tipificada diretamente como crime, não é reconhecida formalmente como profissão, o que impede o acesso a inúmeros direitos e garantias trabalhistas, como o direito de se organizar o seu próprio trabalho em forma de cooperativas.

Segregada e abjeta simbolicamente de grande parte dos níveis de interação social (moral, sexual, religioso, legal e espacial), a atividade de prostituição apresenta uma rede de elementos heterogêneos e, amiúde, opostos entre si, e forças que (inter)agem, determinandose e disputando influência, cujo resultado é capaz de delimitar um possível dispositivo para sua significação, o que tentar-se-á indicar a seguir.

\section{Lógica dissertativa}

O objetivo principal do trabalho é identificar as várias versões da prostituição de rua na avenida W3 norte de Brasília, tendo em conta três aspectos principais: o exercício da atividade de prostituição, a apropriação da prostituição no espaço urbano e a relação entre a prostituição, vulnerabilidade e criminalidade. Para tanto, a bricolagem dessas várias versões será entrelaçada a partir da ideia do conceito de dispositivo de Foucault, o qual permite, em síntese, a análise de um fato social sobre suas mais diferentes vertentes, desde aspectos objetivos como disposição espacial e temporal aos subjetivos, como representações dos atores sociais sobre o tema específico.

Nesse contexto, a lógica dissertativa está organizada em: introdução (o presente segmento), 5 capítulos e conclusão.

Ao fim de cada capítulo, tem-se a construção provisória do dispositivo de prostituição na Avenida W3 norte, que assim cresce em complexidade ao longo da dissertação.

provida quase que inteiramente pela produção para o mercador, isto é, para compradores inteiramente desconhecidos, que nunca entram pessoalmente no campo de visão propriamente dito do produtor" (SIMMEL, 2005). 
Considerando os elementos do dispositivo, os capítulos organizam-se em gradativa complexidade sobre as narrativas sobre a prostituição e crime na cidade, no caso, na Avenida W3 norte. Assim, no Capítulo 1, "A Prostituição e a W3 norte”, apresenta-se a disposição dos elementos urbanos e também sua interação com o tempo, ou seja, a Avenida W3 norte e sua apropriação ao longo das diferentes horas do dia e da noite.

Adicionando complexidade ao espaço estudado, o Capítulo 2, "A criminalidade e a prostituição na W3 norte", será destinado a análises das ocorrências policiais de crimes relacionados à atividade de prostituição na Avenida W3 norte e arredores, nos últimos 5 anos, visando a uma "pretensa" identificação de áreas onde esse tipo de criminalidade ocorre com mais frequência, como forma adicional de entender a dinâmica da prostituição naquele local.

Considerando que os números só revelam apenas um verso das várias versões, o Capítulo 3, “'Luz na passarela que lá vem elas'- As prostitutas da W3 norte”, dá voz às protagonistas da pesquisa, apresentando o resultado das entrevistas realizadas mais de 10 prostitutas da Avenida W3 norte, entre os meses de junho e agosto de 2015 e maio e setembro de 2016. Uma vez que as entrevistas foram semiestruturadas, foram abordados vários tipos de temas, desde suas visões sobre a atividade de prostituição, vida cotidiana, relação com clientes, com a cidade e a vulnerabilidade da rua.

O Capítulo 4, "Elas, segundo os outros", tem como objetivo apresentar as entrevistas realizadas com clientes, policiais militares, policiais civis, responsáveis pela segurança da Avenida W3 norte, e profissionais que orbitam ao redor da atividade de prostituição. As entrevistas também foram feitas, regra geral, de maneira semiestruturada e abordaram temas sobre a prostituição em seus vários aspectos na Avenida W3 norte.

Já, o Capítulo 5 "Elas, na versão da Academia" dedica-se ao mapeamento de como o tema da prostituição é tratado pela comunidade acadêmica e também pelo movimento feminista de forma a se estabelecer um diálogo com os capítulos anteriores, nos quais foram abordadas as ideias das próprias agentes sociais. A narrativa acadêmica sobre o tema é também um aspecto fundamental na constituição do dispositivo da prostituição de rua, uma vez que reforça e reproduz representações sociais.

Finalmente, nas considerações finais, com a reunião de todos os aspectos objetivos e subjetivos sobre os temas da prostituição, da criminalidade a ela associada e a cidade, desenvolvidos ao longo trabalho apresenta-se um possível dispositivo para a prostituição de rua na avenida W3 Norte. Ademais, indicam-se também apontamentos para novas abordagens do tema em pesquisas futuras. 


\section{Capítulo 1 - A prostituição e a W3 norte}

\section{A cidade moderna e a prostituição}

“Stadt Luft macht frei”! Esse é um conhecido adágio medieval alemão que significa literalmente "o ar da cidade liberta". Os viajantes eram recebidos por essa frase nos portões das cidades que integravam a Liga Hanseática ${ }^{66}$, ressaltando que o espaço urbano garantiria uma maior liberdade a seus cidadãos, em contraste com o controle feudal, das famílias nobres, proprietárias de terras.

Apesar de se tratar de um dito de origens medievais, seu significado reflete bem o espírito das mudanças econômicas, sociais e culturais trazidas pela modernidade e o capitalismo, em especial nas grandes cidades. Houve grandes mudanças, por exemplo, na relação entre indivíduo, sociedade e Estado, entre campo e cidade, bem como na percepção do tempo e do espaço. "O século XVIII conclamou o homem a que se libertasse de todas as dependências da história quanto ao Estado e à religião, à moral e à economia" (SIMMEL, 1973, p. 10). Em grande medida, foi esse o objeto de estudo dos sociólogos clássicos, Weber, Marx, Durkheim e Simmel ${ }^{67}$, mesmo utilizando terminologias diferentes. Naturalmente, o chamado à liberdade trazido pela nova sociedade industrial não pode ser imediata ou completamente atendido tendo em vista o longo processo demandado pelas mudanças nas representações sociais, conforme já tratado em um momento anterior. Assim, representações sociais de tempos mais antigos permaneceram mesmo na nova cultura capitalista.

Um dos principais fatores nessa mudança foi o notável crescimento das cidades no contexto da Revolução Industrial, e o surgimento de uma cultura específica dessas grandes cidades, que provocou mudanças relevantes nas relações sociais, entre as quais na atividade de prostituição. Observa-se que, aliada à intensificação do comércio e da circulação de mercadorias e capitais, Simmel observou a cidade a partir da "base psicológica do tipo metropolitano de individualidade consiste na intensificação dos estímulos nervosos. (...) Ele age com a cabeça, ao invés de com o coração" (SIMMEL, 1973, p.13). As relações sociais

\footnotetext{
${ }^{66}$ A Liga Hanseática era uma forte rede de comércio, fundada em 1611, que distribuía mercadoria por todo Norte da Europa, passando por Gênova, Veneza, Londres, Países Baixos e portos do Norte da Alemanha. (SENNETT, 2003, pp. 136-138.)

${ }^{67}$ Com terminologias diferentes, os sociólogos clássicos estudaram bastante as modificações sociais introduzidas pelo sistema capitalista e também pela urbanização nas cidades europeias. Weber, por exemplo, intitulou as mudanças sociais vividas na Europa como uma transição de uma sociedade pré-capitalista, irracional, primitiva, para uma sociedade capitalista, moderna, racional (WEBER, 2002). Marx assinalou a mudança de uma sociedade pré-capitalista, feudal, para uma sociedade ou modernidade capitalista (MARX, 1996). Por sua vez, Durkheim, apontou para a mudança de uma sociedade primitiva, onde a solidariedade mecânica predomina, para uma sociedade superior, industrial, com predomínio da solidariedade orgânica (DURKHEIM, 2013). Finalmente, no caso de Simmel, a mudança de uma cultura subjetiva para uma cultura objetiva, permeada pela impessoalidade do dinheiro (SIMMEL, 2005).
} 
antes subjetivas, ligadas pela familiaridade e parentesco da vida rural, na cidade, tornam-se impessoais, objetivas, e circundam e são circundadas por relações econômicas. Essas relações econômicas apresentam-se, de maneira predominante, na forma de dinheiro, o que conduziu Simmel a sustentar que o dinheiro, nesse contexto, "reduz toda qualidade e individualidade à questão: quanto? Todas as relações emocionais íntimas entre pessoas são fundadas em sua individualidade, ao passo que, nas relações racionais, trabalha-se com o homem como um número, como um elemento que é em si mesmo indiferente" (SIMMEL, 1973, p. 13).

Essa psicologia do tipo metropolitano, aventado por Simmel, além da objetividade e racionalidade, também é caracterizada pelo anonimato, pela interação com completos desconhecidos, marcada pelos afazeres metropolitanos com hora e duração marcadas. Pontualidade, exatidão, calculabilidade, agilidade, rapidez, são características exigidas do habitante da metrópole, o qual desenvolve estratégias para lidar com essa "intensificação de estímulos nervosos" ou com o excesso de informações e de trocas. Nesse contexto, como estratégia de sobrevivência na metrópole, Simmel observa o desenvolvimento de uma atitude blasé pelo tipo citadino, a fim de não absorver todos os estímulos nervosos que lhes são demandados ${ }^{68}$. "A essência da atitude blasé consiste no embotamento do poder de discriminar", o qual é nivelado pelo dinheiro, "o mais assustador dos niveladores. O dinheiro, com toda sua ausência de cor e indiferença, torna-se o denominador comum de todos os valores; arranca irreparavelmente a essência das coisas, sua individualidade, seu valor específico e sua incomparabilidade". (SIMMEL, 1973, p. 16)

Dito isso, a partir da caracterização da prostituição como o exercício habitual do comércio do próprio corpo para a satisfação sexual de número indeterminado de pessoas, é possível perceber uma estreita relação entre a prostituição e a grande cidade moderna. Isso porque, tomando como referência as ideias de $\operatorname{Simmel}^{69}$, o contexto dessas cidades trazem não só o anonimato, mas a objetivação promovida pela impessoalidade das relações sociais trazidas com a troca monetária, e a redução de valores qualitativos a valores quantitativos (quanto custa?). Naturalmente, não se afirma a inexistência da atividade de prostituição antes da existência dos grandes centros urbanos. O que se enfatiza é o processo de sua intensificação enquanto atividade mercantil, objetiva e profissional.

\footnotetext{
68 “Isso não significa que os objetos não sejam percebidos, como é o caso dos débeis mentais, mas antes que o significado e valores diferenciais das coisas, são experimentados como destituídos de substância. Elas aparecem à pessoa blasé num tom uniformemente plano e fosco; objeto algum merece preferência sobre outro.” (SIMMEL, 1973, p. 16)

${ }^{69}$ Simmel chegou a tratar do tema da prostituição diretamente em alguns textos de sua obra, principalmente em seu livro "A Filosofia do Amor", considerando-a como uma atividade em que as mulheres de baixa renda seriam sacrificadas para proporcionarem aos homens não casados uma vida sexual normal e proteger a castidade de outras mulheres (SIMMEL, 2006). Contudo, ressaltam-se, nesse momento, suas reflexões sobre a objetivação das relações sociais promovidas pela metrópole e pela relação monetária trazida pela ideia do dinheiro, e seu impacto na atividade de prostituição urbana.
} 
Nesse sentido, a quantificação do tempo de prestação do serviço, verificada pela cronometragem do programa, e pela prévia combinação de suas características (sexo oral, anal, vaginal, massagem erótica) objetivam e tornam impessoais as relações sociais em torno da prostituição. A estratégia da "atitude blasé", teorizada por Simmel, aplica-se também à prostituição urbana, que pode ser interpretada como um escudo da profissional, visando proteger-se do estabelecimento do vínculo emocional com os clientes, o que possibilita a realização de sua atividade de forma racional e ainda mais produtiva.

A divisão do trabalho social e a contínua especialização das atividades realizadas na cidade são analisadas por Durkheim, Weber e Simmel $^{70}$ como um dos fatores que reforçam essa cultura do distanciamento ou objetivação das relações sociais. A divisão do trabalho está presente também no ramo da prostituição, que pode ser separada em diferentes segmentos, cada um deles com a sua especificidade, como o local onde a prostituta oferece os seus serviços, o seu público alvo, e as espécies de atividades sexuais que ela se dispõe a fazer.

Todavia, o mesmo ar da cidade ${ }^{71}$ que trouxe o anonimato e a objetivação das relações pessoais, trouxe também a maior segregação espacial no ambiente urbano. Afinal, como lembra Park, a cidade é mais que um amontoado de homens individuais, ruas, luzes e instituições. É também um espaço de significações. Antes, “a cidade é um estado de espírito, um corpo de costumes e tradições e dos sentimentos e atitudes organizados, inerentes a esses costumes transmitidos por essa tradição". (PARK, 1973)

Essa segregação pode ser explicada, em parte, pela forma como a cidade é organizada. Nesse ponto, observa-se que a cidade moderna é organizada em seus equipamentos pela sua funcionalidade, havendo setores de prestação de serviços, comércios, áreas de lazer, zonas de circulação. Contudo, pode-se dizer que a cidade também se organiza simbolicamente pela significação que seus habilitantes atribuem a certos espaços ${ }^{72}$. A essas regiões ou espaços da cidade com especial significado, Park denominou de regiões morais, que seriam não um local de domicílio, mas um ponto de encontro, um local de reunião, onde as pessoas tendem a se

\footnotetext{
${ }^{70}$ Como visto acima, Marx teve e ainda tem grande importância para a compreensão da modernidade e do capitalismo. Todavia, no que tange especificamente ao estudo das grandes cidades, mostram-se mais importantes, no contexto do presente trabalho, a obra dos autores mencionados.

71 "O velho adágio [Stadt Luft macht frei] que descreve a cidade como o ambiente natural do homem livre ainda permanece válido na medida em que o indivíduo encontra nas possiblidades, na diversidade de interesses e tarefas, e na vasta cooperação inconsciente da vida citadina a oportunidade de escolher sua vocação própria e de desenvolver seus talentos individuais peculiares" (PARK, 1973).

72 "Cada parte da cidade tomada em separado inevitavelmente se cobre com os sentimentos peculiares à sua população. Como efeito disso, o que a princípio era simples expressão geográfica converte-se em vizinha, isto é, uma localidade com sentimentos, tradições e uma história sua. Dentro da vizinhança a continuidade dos processos históricos é de alguma forma mantida. O passado se impõe ao presente, e a vida de qualquer localidade se movimento com um certo momento próprio, mais ou menos independente do círculo da vida e interesses mais amplos a seu redor.” (PARK, 1973, p. XX).
} 
segregar não apenas de acordo com seus interesses, mas de acordo com seus gostos e seus temperamentos. (PARK, 1973).

As regiões morais trabalhadas por Park têm um caráter volitivo, ou seja, elas se formariam naturalmente, unindo pessoas com gostos e interesses comuns em uma determinada parte da cidade, por sua própria vontade. Assim, dessa perspectiva, seria uma espécie de segregação voluntária por parte dessas pessoas. Contudo, a história social e das cidades nos conta trágicos episódios em que essa segregação deu-se de forma violenta. Assim, para certos grupos sociais, a tal libertação dos ares urbanos era bem mais limitada.

Sennett (2003) nos lembra de que, no início do século XVI, Veneza, o então centro comercial da Europa, iniciou uma política segregadora dos judeus ${ }^{73}$, ao criar o primeiro gueto destinados a este grupo ${ }^{74}$. Eles eram habitantes úteis para a cidade, por suas habilidades comerciais, mas desprezíveis, intocáveis, em razão de uma narrativa construída ao longo de representações sociais que envolviam religião, poder econômico e sexualidade. $\mathrm{O}$ toque de mãos ou o beijo, que era importante, na época, para a confirmação do contrato comercial, ainda mais nessa cidade que vivia das trocas, não podiam ser utilizados quando um dos envolvidos no negócio era um judeu, pois ele era intocável (SENNETT, 2003, p.183). Essa narrativa separatista teve basicamente três pilares, segundo conta Sennett: a identificação da atividade comercial à sensualidade, à usura e à noção de sujeira, dimensões essas que devem ser examinadas separadamente.

A sensualidade era vista na própria cidade que, em razão do comércio, abrigava todos os tipos de pessoas e de fés, com gôndolas coloridas, arquitetura rebuscada com influências árabe e asiática, e luzes, ambiente que influenciava o estado de espírito do veneziano. Além disso, "o comércio de especiarias também contribuía para essa imagem sensual, graças às propriedades afrodisíacas do açafrão e do gengibre dourado”. (SENNET, 2003, p. 189).

Já a ideia de usura, prática condenada desde a Antiguidade, na qual Aristóteles a conceituava como "ganhar dinheiro com dinheiro, que não se reproduz como um animal" (ARISTÓTELES, 2000, p. 161), tinha sua ojeriza situada na ausência de geração de qualquer valor, ao menos na percepção de seus detratores.

Finalmente, a ideia de sujeira, imundice era associada aos judeus a partir da difusão da representação social de que eles eram portadores e transmissores de doenças por não terem

\footnotetext{
${ }^{73}$ Segundo Sennett, para os judeus venezianos, "o adágio medieval "Stadt Luft macht frei" deixaria um gosto ainda mais amargo na sua boca, pois o direito de fazer negócios na cidade não lhe garantia nenhuma outra liberdade. Ele contratava em igualdade de condições, mas vivia segregado". (SENNETT, 2003, 182).

${ }_{74}$ Os judeus eram segregados em uma parte da cidade de Veneza conhecida como "Guetto Nuovo". Em italiano, gettare significa escorrer, despejar.
} 
bons hábitos higiênicos, responsáveis assim pelas pestes que periodicamente atacavam todas as grandes cidades da época.

A mesma lógica de tratamento e de construção de representações sociais dos judeus era aplicada às prostitutas, envolvendo as ideias de sensualidade, sujeira e usura. A sensualidade na prostituição é inata, afinal cuida-se da comercialização dos prazeres carnais. A ideia da usura aplicada à prostituição se justificava porque, igualmente ao lucro do dinheiro com o próprio dinheiro, não haveria nesta última qualquer agregação de valor, uma vez que não se exige qualquer desenvolvimento de técnica específica para tanto. "Não havia treinamento para essa profissão, como na advocacia, por exemplo. E, ao contrário das gueixas, no Japão, o comportamento das cortesãs medievais nada tinha a ver com artes sociais e rígidos rituais transmitidos de geração em geração: ela tinha que se educar sozinha". (SENNETT, 2003, p. 199). Era como se não houvesse qualquer prestação de serviço ou esforço para receber o dinheiro, cujo recebimento, nessa medida, era injustificado. Era um "dinheiro fácil", representação essa que permanece até os dias de hoje. Dessa forma, eram tidas como vagabundas. Por último, a associação da sujeira à prostituição era uma ideia corrente, graças a uma narrativa médica desqualificadora que identificava judeus e prostitutas como disseminadores de doenças. Em especial, as prostitutas eram vistas como difusoras de doenças sexuais, principalmente a sífilis, grande preocupação daquele momento na sociedade veneziana. Assim, essas circunstâncias uniram o destino dos dois grupos na segregação no gueto de Veneza. Logo, eles foram tratados como corpos estranhos na urbe, "fazendo com que ambos usassem roupas e símbolos amarelos. Habitualmente, cada cidadão já vestia um uniforme característico de seu status ou profissão, mas essa cor converteu-se na marca dos dois grupos discriminados" (SENNET, 2003, p. 200).

Ao longo do tempo, estratégias segregacionistas da prostituição na cidade repetiram-se e repetem-se, frequentemente e até os dias atuais, com a justificativa da organização social e do embelezamento da cidade. "Mal necessário, a prostituição deveria ser tolerada, porém controlada e subjugada ao império da razão e da violência policial” (RAGO, 1991, p. 112). Foi assim no século XIX em Paris, com política segregacionista das maisons closes, bordéis destinados à prostituição em locais fechados, sob a responsabilidade de um proprietário e licença para funcionamento. Estratégia boa para o Estado, que detinha o controle da atividade e recebia impostos, para os clientes que tinham a discrição garantida. Só não era boa para as 
prostitutas que se submetiam aos proprietários das casas, dividindo lucros injustamente ${ }^{75}$ (CORBIN, 2015, p. 40-43).

No Brasil, também há vários exemplos de segregação e da tolerância com base na ideia de prostituição como um "mal necessário". Regina Mazzariol (1976) descreveu, na sua dissertação de mestrado, a “operação limpeza”, responsável pelo confinamento da prostituição na cidade de Campinas em uma área afastada, o Jardim Itatinga. Ela relatou várias consequências negativas para as prostitutas decorrentes dessa segregação. Entre elas, pode se destacar a perda de clientela, já que o novo ambiente era longe e com pouca infraestrutura, a degradação da imagem moral da atividade refletida em jornais de grande circulação da região e a própria violação da dignidade das prostitutas, impedidas de circularem em certos pontos da cidade. "Prostituição é, pois, a 'sujeira' que deve ser varrida para um lugar onde não perturbe a ordem estabelecida, não pode conviver com a ordem por oferecer risco de contágio, mas também não deve ser destruída, por ser necessária à conservação da ideia de ordem" (MAZZARIOL, 1976, p. 13).

Com a mesma estratégia de controle pelas autoridades policiais e sanitária, em Belo Horizonte, as prostitutas foram confinadas na área central da cidade, na localidade que o imaginário social nominou como "zona boêmia da Guaicurus", uma região de relevo mais baixo que justificava geográfica e simbolicamente a expressão mineira de "descer para a zona", apesar de, atualmente, o modelo de prostituição no local ter se modificado bastante ${ }^{76}$ (SILVA, 2008, p. 92) (BARRETO \& PRADO, 2010, p. 196).

Talvez o maior exemplo de segregacionismo urbano da prostituição no Brasil tenha sido a criação da "Vila Mimosa", no Rio de Janeiro, para a transferência da prostituição tradicional na área do Mangue, tendo como justificativa o ordenamento urbano, a "modernização do Rio

\footnotetext{
${ }^{75}$ As maisons closes parisienses, no século XX, também sofreram com vários ataques moralistas, principalmente com a atuação de Marthe Richard, que ficou conhecida como "La veuve qui clôt", que em francês significa a "A viúva que fecha". Ela se tornou viúva duas vezes, de homens abastados na Primeira e Segunda Guerras Mundiais, tendo recebido uma boa herança e se tornado bastante influente na sociedade francesa de forma que, na primeira eleição que foi possível a participação das mulheres, foi eleita para o Conselho Municipal de Paris. Marthe foi bastante atuante no fechamento dessas "casas de tolerância" ou de "prostituição" em Paris, que em 1945, havia mais de 1.400 na cidade. Com sua grande influência, principalmente com um discurso de que as prostitutas colaboram com a GESTAPO durante a ocupação nazista de Paris, e também com uma postura moralista e sanitarista, ela conseguiu fechar as casas, sendo conhecida como "A viúva que fecha". Por conta de sua reputação e também por ser conhecida com "A viúva alegre" e também bem rica, ela recebeu o apelido de "La Veuve qui clôt", em referencia ao champagne famoso Veuve Clicquot. (DEMEUDE, 2015, pp. 52-53)

76 "De 1970 aos dias atuais, a prostituição se expandiu para novas regiões, intensificando também a prostituição masculina, nas figuras do michê e dos travestis. Com essa reorganização espacial, a atividade deixou de ser confinada a uma região moral e suas características, os locais de exercício e o relacionamento entre prostitutas e clientes mudaram. Especialmente na região central da cidade, os cabarés desapareceram, dando lugar aos "hotéis de batalha". Estes hotéis são estabelecimentos cujos quartos são alugados por prostitutas para a prestação do serviço sexual. A relação entre as prostitutas e os gerentes destes hotéis é diferente daquela que elas mantinham com as cafetinas; o gerente não exerce controle sobre elas, mas em contrapartida não atua como mediador de conflitos. As relações entre clientes e prostitutas também se tornaram mais impessoais, especialmente pela supressão dos espaços de socialização, como a pista de dança e o bar, e pela curta duração do programa" (SILVA, 2008, pp. 93-94).
} 
de Janeiro", e também práticas de controle sanitarista ${ }^{77}$ (SIMÕES, 2010). Assim, foi criada a Vila Mimosa, uma "cidade cenográfica da prostituição carioca", (SIMÕES, 2010), que concentrou a atividade de prostituição em bordéis ou "casas", unidades estruturantes da dinâmica dos serviços prestados, onde há relações entre o gerente da casa ${ }^{78}$, as prostitutas e os clientes.

A história da prostituição em Brasília é mais recente, até porque, comparando com Rio de Janeiro e Belo Horizonte, ela é uma cidade bem mais nova. Não conta com momentos marcantes na linha do tempo como a criação da Vila Mimosa. Mas também em Brasília a prostituição encontra-se segregada em certos espaços da cidade, cuja delimitação e razão de ser estudaremos a seguir.

\section{Rodando bolsinha na cidade sem esquinas}

A representação social da prostituição de rua remete à ideia do faire du troittor, expressão em francês que, no Brasil, significa ficar na calçada, na esquina, à espera de clientes. Falar de prostituição de rua em Brasília, em princípio nos leva a um paradoxo: como "rodar bolsinha na cidade sem esquinas"?

Para responder essa questão, levei em conta livros, dissertações, artigos de revistas e jornais, mas também a minha observação do espaço da cidade. No entanto, como moradora há mais de 20 anos de Brasília, foi necessário um exercício de estranhamento na cidade ${ }^{79}$, a fim de tentar perceber elementos do espaço urbano estranhos às minhas rotinas cognitivas. Para tanto, utilizei o método da observação flutuante, desenvolvido pela antropóloga Colette Pétonnet, que consiste na postura do pesquisador em "permanecer vago e disponível em toda a circunstância, em não mobilizar a atenção sobre um objeto preciso, mas em deixá-la 'flutuar' de modo que as informações o penetrem sem filtro, sem a priori, até o momento em

\footnotetext{
${ }^{77}$ A região do Mangue no Rio de Janeiro concentrou pessoas de todos os lugares, o que facilitava a atividade de prostituição. Interessante observar que a narrativa sanitarista do controle da prostituição transpôs o imaginário social e consolidou-se em linguagem. Por exemplo, a origem da palavra encreca, em português, vem do ídiche, dialeto judaico - ein krenke - que significa uma doença, que naquele contexto era para indicar os clientes possivelmente infectados por doenças venéreas. (SIMÕES, 2010).

78 "No dia-a-dia, essa estrutura, tão rígida, interpenetra-se com as relações pessoais (amizades), fazendo com que o significante oscile entre dois significados pertencentes aos domínios distintos do público e do privado, ou seja, aos universos do trabalho e da moradia, onde se desenvolve intimidades e redes de proteção, muitas vezes de cunho paternalista, que lhe conferem uma forma de privacidade e controle equiparável à do domínio doméstico". (SIMÕES, 2010).

${ }^{79}$ Como bem lembrou Magnani, "existem algumas precauções que o antropólogo urbano procura tomar e uma delas diz respeito à forma como encara seu objeto de estudo. Se diante de uma cultura radicalmente diferente da sua a atividade é no sentido de procurar transformar o 'exótico', ou melhor, que lhe aparece inicialmente como estranho, sem sentido - porque ainda não conhecido - em familiar, o caminho daquele que enfrenta sua própria sociedade é inverso: trata-se, aqui, de transformar o familiar, o que já é (aparentemente) conhecido em estranho, de forma a escapar à armadilha do senso comum." (MAGNANI, 1993).
} 
que pontos de referência, de convergências, apareçam e nós chegamos, então, a descobrir as regras subjacentes" (PÉTONNET, 2008, 102).

Assentado esse ponto, observa-se que, além de centro de poder e símbolo da modernidade arquitetônica, uma recorrente representação social atribuída à Brasília é ser ela uma "cidade sem esquinas" ${ }^{80}$. Apesar de essa afirmação depender de opinião de cada habitante ou visitante, o fato é que suas ruas largas e amplas, entrecortadas por muitas rotatórias, a prevalência de carros em detrimento de pessoas e a distância entres os mobiliários urbanos, levam a confirmar essa impressão de ausência de esquinas ${ }^{81}$ e do contato humano normalmente associado a esses locais. Tal característica influencia diretamente na dinâmica das relações sociais e, principalmente, na prostituição de rua conforme se verá adiante.

Brasília é uma cidade planejada, resultado da concretização da mudança da Capital Federal do Rio de Janeiro, prevista desde a Constituição de 1891. Contudo, apenas em 1957, o projeto de Lúcio Costa, brasileiro nascido na França, venceu o concurso de urbanismo para a construção de Brasília. Seu projeto foi influenciado pelas ideias modernistas tanto da arquitetura quanto do urbanismo, que, na época, tinha como seu expoente o arquiteto francês Le Corbusier ${ }^{82}$, cujas principais ideias foram condensadas na Carta de Atenas ${ }^{83}$, que tinha por pressuposto básico que a cidade tinha quatro funções básicas: habitar, trabalhar, circular e cultivar o corpo e o espírito.

A construção da nova Capital teve vários objetivos econômicos, políticos e também sociais (CORBISIER, 1960), mas o que interessa aqui é observar como foram reproduzidas as representações sociais relacionadas à prostituição na nova cidade, ou seja, o estudo da

\footnotetext{
80 "Brasília, a cidade sem esquinas" é uma representação social oficialmente reconhecida pelo Governo Federal, já que esse é título de um texto que descreve as características da Capital Federal. http://www.brasil.gov.br/turismo/2014/02/brasilia-umacidade-sem-esquinas consulta realizada em 16/09/2016. Acredito que a fama da ausência de esquinas em Brasília seja internacional. Quando visitei, em 2006, o Reichstag, o Parlamento Alemão, que fica em Berlim, disse para uma alemã também turista que eu era de Brasília e ela logo me disse, em alemão: “Ah! Eu sei, a "cidade sem esquinas”!

${ }^{81}$ A escritora Clarice Lispector imortalizou sua impressão da ausência das esquinas em Brasília: "Brasília é uma cidade abstrata. E não há como concretizá-la. É uma cidade redonda e sem esquinas. Também não tem botequim para a gente tomar cafezinho. É verdade, juro que não vi esquinas. Em Brasília não existe cotidiano. A catedral pede a Deus. São duas mãos abertas para receber. Mas Niemeyer é um irônico: ele ironizou a vida. Ela é sagrada. Brasília não admite diminutivo. Brasília é uma piada estritamente perfeita e sem erros. E a mim só me salva o erro. [...] Paro um instante para dizer que Brasília é uma quadra de tênis... Brasília tem cheiro de pastas de dentes... quero voltar e decifrar seu enigma. Quero, sobretudo, conversar com os universitários. Quero que eles me convidem para participar dessa aridez luminosa e cheia de estrelas. Será que alguém morre em Brasília?" (LISPECTOR, 1999, p.44-7)

${ }^{82}$ Le Corbusier (1887-1965) foi um arquiteto, urbanista, escultor e pintor francês, considerado um dos mais importantes arquitetos do Século XX, cujas ideias principais referem-se à conformação das transformações trazidas pelo capitalismo com a cidade, por exemplo, rapidez no deslocamento de veículos, volume de tráfego, heterogeneidade funcional, novas tecnologias. Para ele a cidade deveria ser ordenada e racional. Segundo Magnani, Le Corbusier teria dito: "Precisamos matar a rua!", necessidades da Carta de Atenas, que previa espaços separados para morar, divertir-se, trabalhar e circular. (MAGNANI,1993)

${ }^{83}$ A carta de Atenas foi um manifesto redigido por Le Corbusier (1887-1965), relator do $4^{\circ}$ Congresso Internacional de Arquitetura Moderna (CIAM), realizado em cruzeiro pelo Mar Egeu, em 1933. Suas formulações sumárias e esquemáticas sintetizam as principais ideias sobre urbanismo no contexto do Movimento Moderno. Já na década de 1960, essas ideais foram muito criticadas e são consideradas ultrapassadas atualmente. (SOARES, 2000, p. 54)
} 
Geografia das Sexualidades ${ }^{84}$, um campo de estudo que, segundo TEIXEIRA (2013, p. 21), "colocaria as sexualidades como produto e produtoras do espaço urbano, cartografando seus territórios e práticas".

TEIXEIRA afirma que o primeiro presidente da Companhia Urbanizadora da Nova Capital (Novacap), Israel Pinheiro, teria dito, em um debate sobre a implantação da Universidade de Brasília dentro do Plano Piloto, que "Brasília deve ser uma pacata cidade administrativa, sem a presença incômoda de estudantes e operários” (TEIXEIRA, 2013, p. 7). A afirmação parece que previra a conflituosa relação entre o cenário urbano brasiliense e o que Teixeira chamou de corpos dissidentes, como os homossexuais, travestis e prostitutas ${ }^{85}$, embora eles não tenham sido mencionados expressamente.

A ideologia modernista de limpeza de linhas e organização pareceu ser bastante adequada para os vários propósitos da mudança da capital do Rio de Janeiro para Brasília. Entre eles, encontrava-se a preocupação com a moral social do país. O filósofo e político brasileiro, que foi deputado estadual e federal, no Rio de Janeiro, na época da transferência da capital, Roland Corbisier ${ }^{86}$, disse que "a mudança seria benéfica por destruir um suposto ressentimento das capitais provinciais com o Rio de Janeiro, por ser esta uma cidade de vício, de prazer, afrodisíaca, local de descaminho e veneno para os desprevenidos" (TEIXEIRA, 2013, p. 74).

Ao olhar Brasília de hoje, segundo os dados oficiais, a capital planejada tem uma população estimada de quase 3 milhões de habitantes ${ }^{87}$ e apenas 220.000 habitantes no Planto Piloto, uma das regiões administrativas do Distrito Federal, que abarca a zona central de Brasília $^{88}$, onde se localiza a Avenida W3 norte, objeto da presente pesquisa.

\footnotetext{
${ }^{84}$ Marcelo Teixeira, arquiteto, estudou a Geografia das Sexualidades e sua relação com a arquitetura em Brasília para o público homossexual, e ele destacou áreas como saunas na Avenida W3, o Parque da Cidade Sarah Kubitschek, e o Conic como de interesse para esse público. (TEIXEIRA, 2013).

${ }_{85} \mathrm{http} / / / \mathrm{www}$.jornaldebrasilia.com.br/cidades/presenca-de-garotas-de-programa-incomoda-os-moradores-do-plano-piloto/ http://www.radargama.com.br/trafico-e-consumo-de-crack-intimidam-moradores-da-asa-norte/, consulta em 16/9/16.

86 "Quanto ao aspecto psicológico, a mudança da Capital destrói o ressentimento das províncias em relação ao Rio de Janeiro, considerada apenas, e aliás injustamente, como a cidade do ócio e do prazer, para a qual todos queriam mudar-se, não só porque era a sede do Governo, do Poder Central, mas também ser a cidade do vício e da graça, há tanto tempo decantada na poesia, na música e na literatura. A cidade afrodisíaca das praias cheias de sol, das ladeiras antigas, das estradas noturnas próximas do mar, dos grandes panoramas iluminados. A cidade que, para muito provincianos desprevenidos, tem sido, frequentemente, veneno e descaminho". (CORBISIER, 1960, pp. 58-89) Roland Corbisier foi um filósofo e político brasileiro, inclusive, era deputado federal na época da construção de Brasília.

${ }^{87}$ Segundo o Instituto Brasileiro de Geografia e Estatística, a população estimada de Brasília em 2016 é se 2.977.216 milhões de habitantes, a terceira maior região metropolitana do país, atrás apenas de São Paulo e Rio de Janeiro. Fonte: http://www.cidades.ibge.gov.br/xtras/perfil.php?lang=\&codmun=530010\&search=distrito-federal|brasilia

${ }_{88}$ Apesar de o nome Brasília ser formalmente sinônimo de Distrito Federal, uma área que abrange o núcleo da cidade conhecido como Plano Piloto e também as 31 Regiões Administrativas, cidades periféricas ou "cidades-satélites", Brasília é usualmente referenciada como sendo apenas a área do Plano Piloto, que inclui a região central administrativa, tanto do Estado Federal quanto Distrital, e os bairros da Asa Norte e Asa Sul.
} 
A cidade é dividida, seguindo basicamente a coordenadas geográficas. A avenida W3 refere-se ao ponto cardeal Oeste n. 3, e é uma das vias arteriais que liga o extremo sul ao extremo norte do Plano Piloto. Nesse contexto, a avenida W3 assume extrema importância para a cidade por ser uma via ininterrupta onde, conforme o plano original, concentrar-se-iam as lojas, hospitais, oficinas, escolas, academias e alguns prédios públicos. Contudo, com a introdução do conceito de shoppings e centros comerciais, a importância da avenida W3, como a cardus maximus ${ }^{89}$ da cidade, diminuiu significativamente, apresentando, em alguns pontos, claros traços de decadência.

A extensão da avenida W3 desde o extremo sul ao norte é de 24 quilômetros, os quais são divididos em três áreas, a W3 sul, a região central e a W3 norte. Apesar de integrarem a mesma avenida, é possível notar claramente as diferenças entre elas, tanto espaciais, quanto simbólicas, que afetam diretamente os tipos de relações sociais nelas desenvolvidas. A região central refere-se ao cruzamento das partes norte e sul e forma um eixo de onde se inicia a contagem das quadras de 1 a 16, na direção sul e também na direção norte, conhecidas como Asas. Assim, é possível dizer que existe a Quadra 7 da Asa Sul ou a 7 da Asa Norte. Às quadras $^{90}$ tanto da Asa Sul, quanto da Asa Norte, conjugam-se os números 500 ou 700 (variando de $502^{91}$ a 516 norte ou sul ou 702 a 716 norte ou sul), numeração decorrente da classificação das coordenadas longitudinais da cidade.

Tendo-se como referência a região central e caminhando-se para a Asa Sul, tem-se à esquerda da W3 sul (nas quadras 502 a 516), as lojas, bancos, igrejas, centros comerciais. Já à direita (nas quadras 702 a 716 sul), estão localizadas casas cujos moradores pertencem à classe média e média alta da cidade. Por sua vez, caminhando-se para a Asa Norte, a partir da região central, na parte direita (quadras 502 a 516) localizam-se postos de gasolina, concessionárias de veículos, lanchonetes rápidas, na parte inicial, e já parte do meio para o final, alguns prédios públicos e de escritórios. Na parte esquerda (quadras 702 a 716), ao longo de toda a W3 Norte, têm-se edifícios de dois pavimentos, cujos térreos são ocupados por lojas de todos os tipos, oficinas, escolas de línguas, cursos preparatórios, igrejas, e os primeiros pisos destinados à moradia, especialmente quitinetes.

\footnotetext{
${ }^{89}$ Cardus maximus era, juntamente com a perpendicular decumanus maximus, a principal avenida das cidades romanas, planejadas tendo como base os acampamentos militares. A cardus maximus possuía uma orientação norte-sul e se cruzava com a decumanus maximus. Em geral, na cardus maximus situavam-se as atividades mercantis e políticas-administrativas da urbes. Ou seja, o coração pulsante da cidade. (SENNETT, 2003, p.96)

${ }_{90}$ Oficialmente as quadras são denominadas de Setor de Habitações Individuais Geminado Sul (SHIGS) e norte (SHIGN).

${ }^{91}$ Não existem as quadras 501 e 701 . A contagem começa da 502 e da 702, pois a área que seriam as quadras 501 e 701 tornaram-se setores específicos, como o Setor de Rádio e Televisão, o Setor Hospitalar etc.
} 
A avenida W3 caracteriza-se por ser ampla, com seis faixas para a passagem de carros, três para cada direção, mas, comparativamente, poucas passagens para pedestres, mesmo porque o transporte público em Brasília é precário e o metrô não atende essa região.

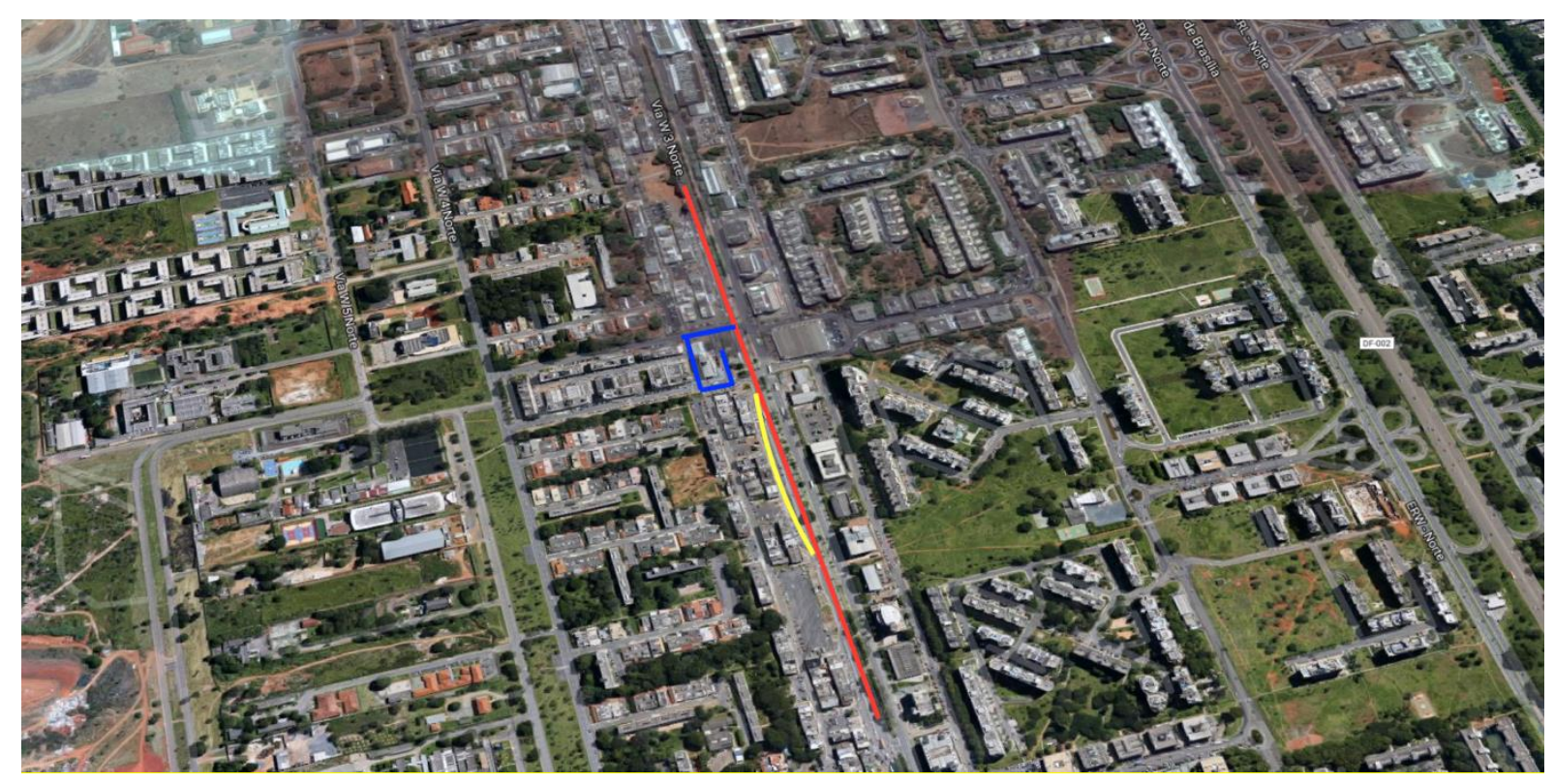

Figura 1. Foto aérea da região da W3 norte

Fonte: Google Maps. A grande linha vermelha ressalta a Avenida W3 norte. A linha amarela indica o trajeto dentro de um dos estacionamentos da avenida. A linha azul demarca o caminho azul necessário para um veículo percorrer para ter acesso ao estacionamento da entrequadras.

Imediatamente paralela à W3 norte, logo atrás das quadras 702 a 716, localiza-se outra avenida arterial, a W4, que possui dois sentidos para o tráfego e é caracterizada por menor luminosidade e evidência. Lá se situam mais apartamentos com metragens muito menores do que do que aqueles das quadras 100, 300 e 200, vários são quitinetes.

Como um espelho, atrás das quadras 502 a 516, tanto no lado sul quanto no norte, está a avenida arterial W2, mas ao invés de quitinetes, não há construções, mas áreas verdes para dar início às quadras residenciais conhecidas como Superquadras, habitadas também pela classe média e média alta. A luminosidade também é menor, comparada à avenida W3.

A apropriação do espaço pela prostituição de rua teria começado na década de 90 , quando um casal de coreanos abriu a boate Queens, no comércio da CLN $314^{92}$. Em seguida, em razão do intenso movimento do estabelecimento, a prostituição feminina foi

92 Reportagem publicada em 30/9/2012, sobre a reação dos moradores contra a prostituição na Asa Norte. http://noticias.r7.com/distrito-federal/noticias/moradores-da-rua-que-ja-foi-ponto-de-prostituicao-repudiam-a-fama-do-local20120930.html (consultado em 19/9/2016)

93 A sigla CLN refere-se ao Comércio Local Norte, localizadas entre muitas superquadras tanto na Asa Sul quanto na Asa Norte. Consiste numa rua cercada de prédios baixos, onde há tanto estabelecimentos comerciais no térreo e subsolo quanto residências nas sobrelojas. 
favorecida e centenas de garotas de programa foram atraídas para o local, oportunidade em que elas começaram a alugar pequenos quartos na vizinhança, para a prestação do serviço sexual (TEIXEIRA, 2013, p. 111).

Contudo, mesmo com o fechamento da boate Queens, as quadras 314 e 714 Norte, ficaram conhecidas na cidade como ponto de prostituição de rua, o que causou intenso pânico moral por parte dos moradores da região, responsáveis por várias campanhas e manifestações para expulsar as prostitutas do local ${ }^{94}$. Inclusive, colocaram em via pública faixas com dizeres como "Nós, moradores da 713 Norte, pedimos socorro urgente às autoridades. Garotas de programa invadem nossas residências. Hoje, elas usam nossas marquises como motéis. Amanhã, elas nos expulsam de nossas casas e usam nossas camas" ${ }^{95}$, foram espalhadas pelas quadras próximas à região, conclamando uma ação pública contra a prostituição.

Em razão da intensa pressão dos moradores e comerciantes locais, as quadras 314, 315, 714 e 715 não são mais referência na prostituição na Asa Norte, havendo um movimento de expansão para toda a avenida W3 Norte. Esse movimento foi verificado tanto pelas minhas observações no local, como pelas análises das ocorrências policiais e também pela pesquisa de Gustavo Capela (2013) sobre a prostituição na W3 norte:

Ao chegar na 315, não encontrei nenhuma prostituta. Fui perguntar a alguns amigos meus que tinham mais contato com a prostituição e eles me revelaram que houve uma mudança. Agora toda a W3 norte tinha prostitutas. Uma das prostitutas com quem mais conversei nesses dois anos de pesquisa uma vez me disse que a razão da saída da 15 foi, além do crescimento do número de prostitutas que queriam oferecer serviço no ponto, devido à presença excessiva da polícia. Os policiais começaram a abordar os clientes que ali passavam para averiguar se estavam portando drogas. (...) Com essa realidade em mente, segundo as prostituas, a polícia passou a enxergar a 315 com polo de comércio de drogas, investigando carros que ali passavam procurando serviços sexuais. A polícia, além de abordar clientes, também passou a abordar com mais frequência as próprias prostitutas. O negócio diminuiu, pois, como diziam na pista: 'nenhum homem quer se parado na 15 pela polícia para ter que sair do carro e todo mundo ver (CAPELA, 2013, pp. 131-132).

\footnotetext{
${ }^{94}$ Nessa reportagem do Jornal de Brasília de 2012, noticia-se ainda "a presença incômoda" das prostitutas de rua nas quadras 314/714 Norte, e a ação dos moradores da região contra elas. http://www.jornaldebrasilia.com.br/cidades/presenca-degarotas-de-programa-incomoda-os-moradores-do-plano-piloto/ (consultado em 19/9/2016). Já esse artigo, publicado em 2003 pelo Departamento de Doenças Sexualmente Transmissíveis, vinculado ao SUS, noticia o avanço da prostituição na Asa Norte, as preocupações com a disseminação de doenças e também a reação dos moradores no local e da polícia, diante do que eles consideram problema. (consultado em 19/9/2016) http://www.aids.gov.br/noticia/prostituicao-avanca-na-asa-norte

${ }^{95}$ Jornal Informativo da Faculdade de Comunicação da Universidade de Brasília. Segundo a reportagem, os moradores e comerciantes da região culpam a prostituição pelo aumento da violência e do tráfico de drogas. http://campus.fac.unb.br/arquivo/campus12014/cidade/item/2108-prostituição-incomoda-moradores-da-asa-norte (consultado em 19/9/16).
} 
Como se observa, as mesmas estratégias de segregacionismo da prostituição urbana se repetem até os dias atuais. Afinal, demarcar um espaço onde determinado tipo de pessoa não pode estar, é também uma forma de segregação. As relações sociais influenciam diretamente a configuração e a apropriação do espaço urbano. E a atual disposição da prostituição na avenida W3 norte é o que se verá a seguir.

\section{A apropriação do espaço e a dinâmica da prostituição na W3 norte}

Além das ideias do método da observação flutuante de Colette Pétonnet, utilizei como chaves de leitura de observação do espaço urbano a metodologia proposta por Magnani, referente à noção de pedaço, manchas, circuito ou trajeto.

Para o autor, a ideia de pedaço tem um viés subjetivo do personagem, referindo-se a uma rede de relações ou a uma sociabilidade estabelecida em torno de um ponto de referência físico ou simbólico. Em suas próprias palavras, tem-se o espaço como "um segmento - assim demarcado torna-se ponto de referência para distinguir determinado grupo de frequentadores como pertencentes a uma rede de relações" (MAGNANI, 1996, p. 13). O ponto de prostituição, por exemplo, poderia constituir a ideia de pedaço, onde uma prostituta exerce sua atividade, delimitando seu espaço em detrimento de outra.

Mancha, por sua vez, já possui um sentido mais objetivo, ou seja, ligada ao território físico, sendo "áreas contíguas do espaço urbano dotadas de equipamentos que marcam seus limites e viabilizam - cada qual com sua especificidade, competindo ou complementando uma atividade prática dominante" (MAGNANI, 1996, p. 19).

Trajeto ou Circuito refere-se à noção de movimento, um deslocamento entre pedaços, ou seja, entre redes de sociabilidades estáveis, ou até mesmo entre manchas, seriam caminhos que ligam áreas descontínuas (MAGNANI, 1996, p. 21).

Utilizei ainda como guia da observação a noção já exposta anteriormente de Região Moral, desenvolvida por Robert Park, que se refere à ideia de segregação espacial na cidade conforme os gostos e temperamentos da população.

Ademais, seguindo ainda a orientação de Magnani (1996, p. 17), elaborei um Roteiro ou Script, capaz de dirigir e organizar minhas observações. Contudo, tendo também como inspiração o método da observação flutuante, procurei estar aberta ao inusitado, mas sempre com atenção para captar o reiterativo, o padrão, as regras, os modos de ser.

Antes de ser iniciada a ida a campo, muitas leituras são realizadas e, ao mesmo tempo, muitas dúvidas são suscitadas. Respostas certas não existem, apenas indicações de outras 
observações realizadas na cidade, por pesquisadoras mais experientes ${ }^{96}$, as quais levaram à necessidade de se observar a atividade de prostituição de rua em dias diferentes da semana e em horas distintas do dia.

Assim, fiz observações, nos meses entre junho a agosto de 2015 e maio a junho de 2016, que duravam em média entre três a quatro horas, algumas mais rápidas, outras bem mais demoradas, como seis horas andando ao longo da avenida W3, com pausas para lanche nos bares da região. Fui a pé, de carro, de bicicleta e também de motocicleta. Às vezes, sozinha, outras com amigos para ter olhares auxiliares e compartilhar as impressões. Observei o espaço durante o dia, à noite, bem como em algumas madrugadas e alvoradas.

Quando ia a pé, vestia roupas discretas, calça jeans e camiseta, para não ser percebida como uma estranha no ambiente, mas sempre tinha o cuidado de não usar roupas que pudessem provocar alguma ideia de concorrência com as prostitutas, pois isso poderia ser uma barreira para conversar com elas. Verifiquei que minha roupa fazia diferença sim. Usando roupas mais simples, de calça jeans azul, camiseta e tênis, elas não me davam muito atenção, mas quando ia mais arrumada (calça preta, sapato alto, jaqueta de couro) tive mais sucesso nas interações. Ao total, fui ao "campo" cerca de 20 vezes, especialmente para fazer as observações e entrevistar as prostitutas. Contudo, como sou moradora de Brasília, sempre que era possível, passava pela avenida W3 para observar o movimento, tanto diurno quanto noturno, durante meus deslocamentos diários.

De fato, como ressaltou CAPELA (2013, p. 132) ${ }^{97}$, o anonimato é essencial para a prostituição na avenida W3 norte. Assim, logo no início verifiquei ser impossível gravar as entrevistas, porque nenhuma das prostitutas permitia e só a pergunta já criava um ambiente de distanciamento. Assim, a melhor dinâmica que encontrei era ir de carro, e quando acabava uma entrevista, para não me esquecer dos detalhes, voltava para o carro e lá eu gravava no celular tudo que ouvira, e depois, em casa, transcrevia para o diário de campo.

\footnotetext{
${ }^{96}$ Outros pesquisadores da cidade e também da prostituição na cidade ajudaram-me bastante na identificação de categorias de observação da urbes. Por exemplo, a pesquisa de Soraya Silveira Simões sobre a Vila Mimosa, um espaço no Rio de Janeiro construído e destinado à prostituição, trata da criação desse espaço, das práticas do ofício e também as lutas das prostitutas para a defesa de seus interesses (SIMÕES, 2010). Apesar de haver diferenças entre a prostituição na Vila Mimosa e na Avenida W3 norte em Brasília, o trabalho de Soraya Simões esclareceu aspectos da dinâmica e da linguagem da atividade de prostituição. Sobre o fazer antropológico na prática da cidade, contei com os "insights" de Haydée Caruso em sua pesquisa sobre "a construção da ordem" na Lapa Carioca, entre os quais a relação do espaço físico geográfico e simbólico, a visão de um mesmo espaço físico pelo olhar de diferentes personagens e a (não)-(inter)-relação entres espaços tão próximos e ao mesmo tempo tão distantes (CARUSO, 2009). Especificadamente sobre a prostituição de rua da avenida W3 norte, em Brasília, pude dialogar com as ideias de Gustavo Capela, que fez também um trabalho sobre o "direito à prostituição: aspectos de cidadania", tendo como exemplo entrevistas de prostitutas da W3 norte. (CAPELA, 2013).

97 "Outra coisa que aprendi no campo de pesquisa é que o anonimato é importantíssimo tanto para o cliente como para a prostituta. Ela não quer ser reconhecida na rua por ele e vice versa. Também não querem que conhecidos as vejam na rua e eles tampouco". (CAPELA, 2013, p. 132).
} 
Antes de conversar com os personagens da ação ${ }^{98}$, busquei uma primeira aproximação com a dinâmica da atividade de prostituição, tomando como referência os elementos de observação que possuía e também dos dados sobre a criminalidade relacionada a esta atividade, obtidos em pesquisas anteriores ${ }^{99}$. A partir dessas observações preliminares, pude perceber melhor a dinâmica da atividade e, ao conversar com os personagens, eu tinha mais elementos para a discussão. Aliás, as conversas com os personagens me surpreenderam em vários aspectos que apenas a observação não poderia me responder.

Percorri a W3 norte em diversos horários e dias, de manhã, ao entardecer, de noite e de madrugada, em dias úteis e fins-de-semana. Em cada momento, a avenida apresenta uma feição diferente. Mas o maior contraste que encontrei, foi entre o dia e a noite na W3 norte. Mostra-se também relevante a diferença que existe, na W3 norte, nos dias úteis e no fim-desemana, especialmente na vida diurna da avenida.

Tanto durante os finais de semana quanto nos dias úteis, não observei atividade de prostituição durante o dia na avenida W3 norte.

Durante a semana, a W3 norte é bastante movimentada de dia, com comércio de rua intenso. Observam-se lojas de colchões e de pequenos presentes, cursos de línguas e de artes marciais, escritórios de contabilidade e restaurantes. As lojas comerciais mencionadas ficam nas quadras 700, um lado da avenida W3, de sentido de tráfego norte/sul, e o outro lado, cujo sentido de tráfego é sul/norte, ficam vários prédios públicos, como bancos, agências reguladoras, autarquias, e também o Tribunal Regional do Trabalho da $10^{\mathrm{a}}$ Região, responsáveis por garantir o intenso movimento na W3 norte durante o dia e alimentar o comércio de restaurantes, bares, papelarias e lanchonetes.

Por sua vez, a avenida W4, que fica atrás da W3, é muito viva durante o dia, cheia de lojas de prestação de serviços, escritórios de advocacia, engenharia, oficinas mecânicas, colégios, lojas de "conserta tudo", que vendem peças, igrejas evangélicas, lojinhas de presentes, de móveis usados. Há poucos supermercados, ou quase nenhum, mesmo porque os grandes mercados situam-se nas entrequadras das superquadras 300/100, do lado oposto da W3 norte, onde há mais moradores com maior poder aquisitivo. Na avenida W4, também não há boutiques ou lojas de grifes famosas, porque o clima é de cidade interiorana, não havendo circulação da mesma clientela dos grandes shoppings. Durante minhas andanças por lá,

\footnotetext{
${ }^{98}$ Para as conversas, utilizei o método de entrevistas em profundidade semiestruturada, ou seja, fiz um roteiro das questões (Anexo 3). Conforme as respostas, surgiram outras perguntas que não necessariamente foram feitas a todas entrevistadas.

${ }^{99}$ Como já mencionei, em 2013, fiz uma pós-graduação em Análise Criminal pela Universidade Católica de Brasília, onde analisei as ocorrências policiais relacionadas à prostituição na Asa Norte, entre os anos de 2008-2013. Nessa dissertação, aprimorei o método que utilizei, bem como modifiquei o período considerado, 2010-2015. O resultado desse levantamento será exposto no Capítulo 2 deste trabalho.
} 
escutei várias vezes o caminhão da melancia passando, juntamente com o caminhão da galinha caipira. Um comércio típico de uma cidade normal, cenário muito diferente da racionalidade e modernismo do plano original imaginado para Brasília, onde tudo teria seu lugar certo e exato. É difícil imaginar que na cidade ideal de Corbusier houvesse lugar para o caminhão da galinha caipira.

Em uma manhã de domingo, quando há luz do dia, mas não muita circulação de pessoas e de carros na avenida W3 norte, é possível observar melhor a arquitetura do local. São 15 quadras, denominadas de Comércio Residencial Norte (CRN), com prédios comerciais de dois andares, cujo térreo contém o comércio e a sobreloja, apartamentos ou quitinetes para alugar. Cada quadra tem entre 10 a 14 prédios nesse modelo. Atrás desses prédios há uma pequena viela ou beco que faz fronteira com o lote também comercial que dá acesso à via W4 norte, outra via arterial, com velocidade menor e por isso com menos carros que a W3.

A luz do dia ilumina também os rastros que a noite deixou para trás. Em um desses domingos pela manhã, caminhando pela W4 Norte, na altura da quadra 704 norte, pude observar com clareza três pousadas, nas quais já sabia que, durante a noite, era desenvolvida uma intensa atividade de prostituição. Próximo de uma delas, encontrei mais de 25 restos de cigarro no chão. Parece que eles tinham sido consumidos na noite anterior ou, ao menos, recentemente, porque o espaço ao redor estava limpo. Havia em cima da marquise desse local, um quarto onde várias mulheres conversavam. Possivelmente ali era um ponto de prostituição noturna. Mas, naquele momento, não havia qualquer atividade de prostituição nesse espaço público.

Logo do lado desse local, havia uma porta cuja entrada dava acesso a apartamentos. Na porta havia uma placa feita de cartolina vermelha, plastificada, escrito "Casa de família". Uma clara tentativa do morador de separar ao menos aquela residência do ambiente de prostituição que o cerca. Às vezes são sutis as formas como uma atividade se apropria do espaço onde é exercida. 
Figura 2. Porta casa de família

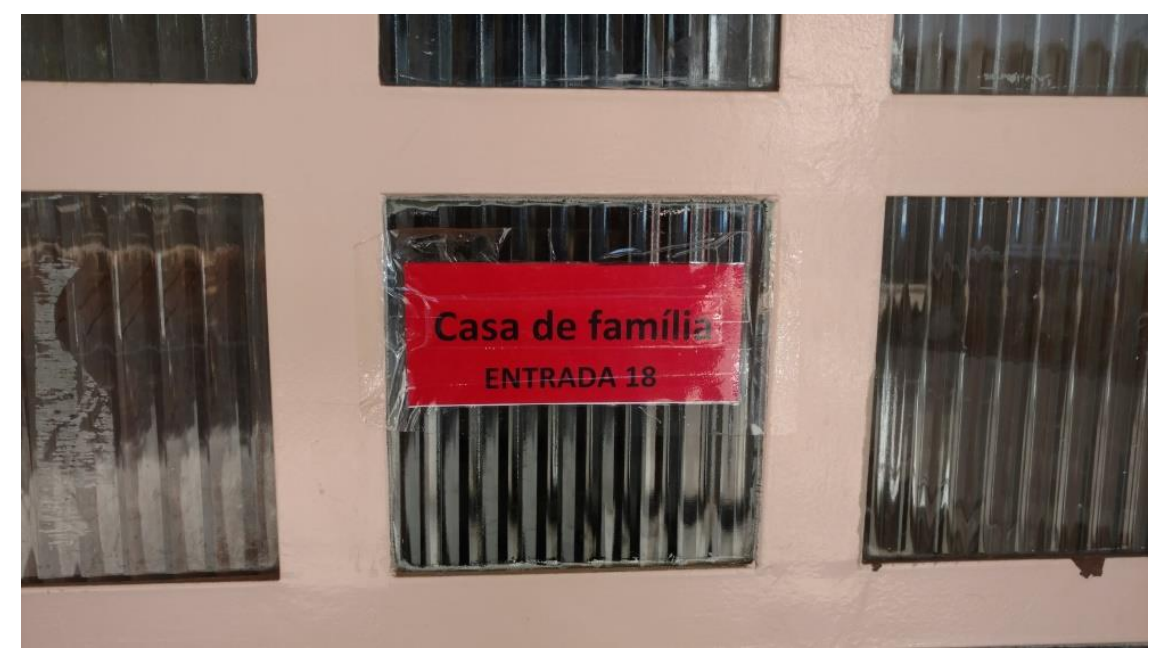

Fonte: Acervo pessoal.

Entre as quadras, há um espaço grande, conhecida como área verde, onde ficam as paradas de ônibus, quiosques de lanches e bancas de jornal. Nesse espaço da área verde, não há estacionamentos e nem circulação de carros. Há espaço para estacionamentos apenas em frente aos comércios da W3 norte, e o sentido de deslocamento dos carros é decrescente, ou seja, das quadras 516/716 para as quadras 502/702, norte/sul, em harmonia com o sentido da via arterial de carros. Apenas depois de muitas idas ao campo e também conversando com as prostitutas, pude perceber a relação desses estacionamentos com a apropriação do espaço da W3 norte pela prostituição.

O clique do relógio para a mudança do ambiente da W3 norte se dá entre $18 \mathrm{~h} 00$ e 19h00. É o horário em que as lojas começam a encerrar suas atividades, os cursinhos preparatórios mudam do turno vespertino para o noturno, as paradas de ônibus estão lotadas de trabalhadores indo para casa, e as ruas repletas de carros e de um tráfego intenso em direção às cidades-satélites que funcionam como cidades pendulares em relação a Brasília.

Aos poucos, a intensa movimentação diurna da avenida W3 norte dá espaço para a iluminação pública amarelada e pouca circulação de pessoas. Surgem áreas de penumbra da interação entre os prédios e a iluminação pública. Ao contrário do cenário diurno de vários restaurantes, durante a noite, há apenas três em funcionamento: Primo Piato (707 norte), Xique-xique (708 norte) e Carne de Sol (712 norte).

Por volta das $18 \mathrm{~h} 30$, nos dias úteis, uma ou outra prostituta aparece timidamente e fica entre os carros parados nos estacionamentos dos comércios. O primeiro lugar onde elas apareceram foi, quase sempre, a 704 norte, onde há uma maior concentração de pousadas, 
locais frequentemente utilizados para a realização de programas. Todavia, independentemente do dia da semana, pode-se dizer que: 1) a atividade de prostituição é exercida, pelo menos ao longo da W3 norte, em sua grande maioria por mulheres; 2) tal atividade concentra-se apenas na avenida W3 norte, entre as quadras 702 até a 716 norte, ou seja, apenas na parte de cima da avenida.

Quanto à primeira observação, ressalto que a grande maioria da atividade de prostituição é exercida por mulheres. Com efeito, não seria a grande maioria, mas toda a atividade de prostituição, porque, a aparência de todas as prostitutas da avenida W3 assume a forma ou o fenótipo feminino. Em momento algum da observação, pude verificar pessoas com o fenótipo de homens oferecendo serviços de prostituição. Sem dúvida, há vários travestis ao longo da W3 norte, mas todos adotam a forma feminina, e, inclusive, eu mesma me confundi ao identificar o gênero dos (as) entrevistados(as) por três vezes, só sabendo que se tratava de travesti ao longo da conversa. Foi exatamente por esse motivo que decidi examinar as prostitutas como um gênero feminino e não em seu aspecto biológico, macho ou fêmea.

A segunda observação, referente à verificação da concentração das prostitutas apenas nas quadras 702 até a 716 Norte, levou-me a um questionamento: ora, porque elas não ficam também do outro lado da avenida W3, nas quadras 500? Fiquei feliz em saber que minhas dúvidas também, de certa forma, eram as de Clarice Lispector, que em seu famoso texto "Brasília: Esplendor”, questionou: “Agora me pergunto: se não há esquinas, onde ficam as prostitutas de pé fumando? Ficam sentadas no chão? E os mendigos? Tem carro? Pois só se pode andar de carro lá” ${ }^{100}$.

A resposta para Clarice e para mim só veio com mais observações. Na "cidade dos carros", como Clarice tinha observado, a prostituição só poderia ocorrer com ajuda dos estacionamentos. E é exatamente por isso, que o espaço físico da avenida W3 norte favoreceu a apropriação do local para a prostituição ${ }^{101}$ na parte de cima, onde o sentido do tráfego é de norte para o sul. Assim, as prostitutas ficam, cada uma em seu espaço ou ponto, delimitado,

\footnotetext{
${ }^{100}$ LISPECTOR, Clarice. Brasília: Esplendor, 1974. Disponível em: http://brasiliapoetica.blog.br/site/index.php?option=com_content\&task=view\&id=1763 Acesso em 19/9/16.

${ }^{101}$ Em revés, é possível que ausência da atividade de prostituição na parte sul da avenida W3 possa ser justificada por uma série de motivos. Ao contrário da parte norte da mesma avenida que possui lojas comerciais, bancos e prédios públicos dos dois lados, a avenida W3 sul na parte superior (quadras 700) possui casas residenciais, a maioria sobrados, onde moram pessoas da classe média alta de Brasília. Naturalmente, a prostituição que não é bem vista pela sociedade não poderia estabelecer-se naquela região de forma tão ostensiva. Outra possível razão é a crescente decadência da avenida W3 sul, tanto durante o dia quanto durante a noite. Caminhando por ela a partir das 22h00, dificilmente encontra-se uma loja comercial aberta, ainda que seja um restaurante. Ademais, os espaços são pouco iluminados e a ausência do fluxo de pessoas prejudica a chegada de clientes, que, temem, possivelmente, ser vítimas de crimes. Finalmente, outro possível motivo é a inexistência de estacionamentos grandes em frente às lojas comerciais, local onde ficam as prostitutas no contexto da W3 norte, já que na avenida W3 sul, os estacionamentos localizam-se no canteiro central da via.
} 
como se em uma vitrine a céu aberto, onde os clientes, em sua grande maioria, motorizados, podem se aproximar e negociar o programa rapidamente, guardando seu anonimato sem sequer sair do veículo. Além disso, a facilidade do veículo garante a maior possibilidade de escolha entre as prostitutas, durante o longo trajeto de mais de dez quilômetros da via W3 norte. Ele pode rapidamente observar e conversar com várias prostitutas até escolher uma.

Inicialmente, fiquei também perplexa com o fato de as prostitutas não ocuparem os grandes espaços entre as quadras comerciais, onde se situam os prédios com mais de dois andares das quadras 700. Quando entendi o movimento dos carros que cruzam a avenida W3 norte como se estivessem olhando vitrines à escolha das prostitutas, vi que eles nunca entravam nesses estacionamentos das entrequadras, pois o sentido da via do trânsito, nesses bolsões é inverso ao da via W3 norte, o que impediria o fluxo. O motorista que segue a sequência das vitrines na W3 norte, teria que dar uma grande volta, ou conduzir o seu veículo na contramão, para ter acesso a esses estacionamentos. Tal dificuldade torna esses locais pouco atrativos para os clientes, que têm acesso muito mais fácil aos estacionamentos das quadras comerciais ao longo da W3 norte. Assim, esses locais não se apresentam como vitrines chamativas.

Ademais, as paradas de ônibus da W3 norte situam-se nesses bolsões de estacionamento das entrequadras da W3 norte. Elas, ao contrário, não impedem o fluxo de veículo, mesmo porque são pontos de embarque e desembarque de passageiros de ônibus. Contudo, elas não são muito ocupadas por prostitutas, pelo menos antes das $23 \mathrm{~h} 30$ horas, pois, segundo as prostitutas que entrevistei, elas disseram que preferem não incomodar as pessoas das paradas de ônibus com sua presença e também elas próprias não se sentem confortáveis, mesmo porque a abordagem dos clientes fica dificultada. Afinal, como já vimos, o anonimato é importante para os dois polos dessa relação. Contudo, depois de 1 h00 da madrugada, quando cessa a passagem de ônibus, é possível encontrar prostitutas nas paradas.

Além disso, outra circunstância favorável à prostituição na W3 norte é a facilidade de mobilidade para os clientes que, mesmo a pé, podem utilizar os serviços sexuais de maneira rápida e furtiva, logo ao saírem do trabalho ou mesmo antes de lá chegarem, mesmo que muito cedo, como me contou uma das entrevistadas. Segundo ela, como o programa é rápido, cerca de vinte minutos, durante a semana esse tempo é facilmente justificado como excesso de trânsito para a família que os aguarda em casa.

Dessa forma, essa localização da prostituição em um espaço ou apenas uma área da avenida W3 norte remete à chave de leitura referente à Região Moral, proposta por Robert Park, que é a segregação da população no espaço urbano conforme seus interesses, gostos e 
temperamentos, ou mesmo um ponto de encontro ou reunião. Essa sugestão de leitura dos setores da cidade, aliás, adequa-se bastante ao próprio território de Brasília, uma cidade planejada, dividida em setores tanto fisicamente quanto simbolicamente. Há quadras destinadas ao comércio em geral, mas há também aquelas que se especializaram em um determinado tipo de venda como, por exemplo, as chamadas Rua das Farmácias, a Rua das Elétricas, a Rua dos Computadores. De igual maneira, assim também ocorreu em considerarse a avenida W3 norte, a partir das quadras 702 a 715, uma região da prostituição noturna.

Brasília atende muito bem à crítica de Jane Jacobs ${ }^{102}$ sobre os modernistas ortodoxos (como Le Corbusier, Mumford e Bauer) que diziam que "a rua é um lugar ruim para os seres humanos; as casas devem estar afastadas dela e voltadas para dentro, para uma área verde cercada. (...) A unidade básica do traçado urbano não é a rua, mas a quadra, mais particularmente, a superquadra. (...) A presença de um número maior de pessoas é, na melhor das hipóteses, um mal necessário, o bom planejamento urbano deve almejar pelo menos a ilusão de isolamento e privacidade, como num subúrbio"(JACOBS, 2000, p.20).

Todavia, "as cidades são locais fantasticamente dinâmicos" (JACOBS, 2000, p.13), talvez porque elas sejam constituídas de seres complexos, criativos e também muito dinâmicos. Assim, ao contrário dos planos dos idealizadores de Brasília, em criar uma cidade longe dos prazeres urbanos, a cidade imaginada deu lugar à cidade real. Antes a cidade foi criada para afastar o uso sexual das áreas públicas (TEIXEIRA, 2013, p. 8), mas agora ostenta a prostituição de rua de baixo de sua asa, na Asa Norte, uma das "asas" do avião, no "Plano Piloto”. A tripulação do avião de Lúcio Costa assumiu o comando e deu outra direção à viagem do urbanista. Anos depois, ele mesmo reconheceu que a cidade deve ser dos habitantes:

Isto tudo é muito diferente do que eu tinha imaginado para esse centro urbano, como uma coisa requintada, meio cosmopolita. Mas não é. Quem tomou conta dele foram esses brasileiros verdadeiros que construíram a cidade e estão ali legitimamente. Só o Brasil... E eu fiquei orgulhoso disso, fiquei satisfeito. É isto. Eles tomaram conta daquilo que não foi concebido para eles. Foi uma bastilha. Então eu vi que Brasília tem raízes brasileiras, reais, não é uma flor de estufa como poderia ser, Brasília está funcionando e vai funcionar cada vez mais. Na verdade, o sonho foi menor do que a realidade. A realidade foi maior, mais bela. Eu fiquei satisfeito, me senti orgulhoso de ter contribuído. (COSTA, 1991, p.5)

\footnotetext{
102 Jane Jabobs foi uma jornalista e ativista canadense que criticou duramente as formas de apropriação do espaço urbano nos Estados Unidos, o que motivou sua prisão em 1968 e sua mudança definitiva para o Canadá. Sua principal obra foi o livro "Morte e Vida das Grandes Cidades", 1961, onde ela critica o projeto urbano subordinado ao excesso de planificação, sem deixar espaço para o potencial das relações sociais na construção e desenvolvimento das cidades.
} 
O espaço público, esse "lugar de visibilidade, espaços onde são desenvolvidas sociabilidade particular, a inserção e a integração" (CALDEIRA, 2000, p. 26), mostra-se ideal como placo e vitrine para as "mulheres públicas", como eram conhecidas as prostitutas no Brasil, nos séculos XIX e XX (RAGO, 1991, p. 20). Modelos nas ruas da cidade, pode-se dizer que as prostitutas exercem uma dupla performance, ao assumirem seus personagens, "dramatizam o trabalho sexual, onde simulam atos sexuais em passarelas-trottoir" e também "dessacralizam" a sua atividade, de forma a considerá-lo um trabalho como qualquer outro. (SIMÕES, 2016). Assim, a performance da prostituição nas passarelas da avenida W3 norte, longe de se esconder nas "asas do avião", convida os espectadores a "abrirem suas asas e soltarem suas feras". E por que não "cair na gandaia"?

A partir da observação, também verifiquei que a dinâmica da atividade de prostituição é realizada da seguinte maneira: as prostitutas ficam em espaços delimitados, sozinhas ou em pequenos grupos, com roupas curtas, sapatos ou botas de salto, maquiadas, exibindo seus corpos, às vezes apoiadas nos carros estacionados em frente às quadras 700, ou sentadas nas calçadas, debaixo das marquises dos prédios comerciais que funcionam durante o dia. Os clientes, em sua grande maioria, passam por ali de carro, escolhem a pessoa para o programa, momento em que a prostituta entra no carro juntamente com ele.

Além disso, percebi que, às vezes, o programa era realizado fora da avenida $\mathrm{W} 3$, em motéis - observação confirmada pelas entrevistas -, ou ainda no próprio ambiente da prostituta, quitinetes alugadas por elas nas sobrelojas das quadras 700 ou ainda nos edifícios localizados na avenida W4 norte, que ficam logo atrás da avenida W3 norte. Aliás, é a partir da projeção desses "ambientes", que se delimita o ponto de cada uma delas.

Assim, tem-se delineada a chave de leitura referente ao pedaço, que estabelece uma rede de sociabilidade tanto entre as demais prostitutas, no sentido de criar-se uma limitação espacial ao ponto de cada uma, quanto também um ponto de referência aos clientes fiéis ao serviço. Seria como se aquele espaço ou pedaço, apesar de ser público e não haver qualquer título de propriedade, pertencesse-lhes, ao menos no período noturno. Tal situação justifica também o meu próprio incômodo ao adentrá-lo, já que sou uma pessoa de outro pedaço. Nas palavras de Magnani, "pessoas de pedaços diferentes, ou alguém em trânsito por um pedaço que não o seu, são muito cautelosas: o conflito e a hostilidade estão sempre latentes, pois todo lugar fora do pedaço é aquela parte desconhecida do mapa e, portanto, do perigo" (MAGNANI, 1998, p. 116-117). 
A distribuição das garotas de programa ao longo da avenida W3 norte não se dá de forma homogênea, de modo que foi possível identificar duas manchas principais. Mancha é uma categoria desenvolvida por Magnani para designar "áreas contíguas do espaço urbano dotadas de equipamentos que marcam seus limites e viabilizam - cada qual com sua especificidade, competindo ou completando - uma atividade ou prática dominante". (MAGNANI, 1996, p. 19).

Observei que há maior concentração das garotas de programa nas quadras 703 e 704 e nas quadras 707 e 708, talvez porque logo atrás dos pontos de prostituição dessas quadras, também havia pousadas, duas no caso das quadras 707 e 708 norte, e três, nas quadras 703 e 704, as quais ficavam abertas, com as luzes acesas até a madrugada. Além das quitinetes, alugadas pelas próprias prostitutas, os programas também são realizados nessas pousadas.

Em um dia movimentado, que costuma ser quarta ou quinta-feira, há mais de 70 garotas de programa nas passarelas da W3 norte. Nos finais de semana e feriados, ao contrário do que eu imaginava inicialmente, o movimento cai drasticamente e, houve dias na observação, como em um domingo à noite, que pensei que todos os habitantes teriam deixado a cidade. $\mathrm{O}$ motivo por trás dessas observações surgiram apenas quando comecei a conversar com as garotas de programa, que me disseram que, como visto acima, durante a semana, é mais fácil para os clientes justificarem sua ausência com a família, alegando excesso de tráfego ou atraso no trabalho, por exemplo. Nos finais de semana, as desculpas são mais difíceis. Contudo, as prostitutas "adaptaram-se à demanda do mercado" e utilizam também os finais de semana para ficaram com seus filhos ou mesmo ir para as cidades onde moram, pois grande parte delas vivem em cidades do entorno de Brasília ${ }^{103}$.

Sobre a participação ou não de terceiros na atividade de prostituição, o conhecido cafetão, o assunto é delicado para conversar com as garotas de programa, mesmo porque há um crime no Código Penal, referente à exploração da prostituição, e naturalmente, elas temem falar sobre isso. Contudo, com minhas observações, durante uma noite longa em que percorri toda a W3/W4 norte a pé, na companhia de um amigo, pude perceber como se dava a ação de um cafetão. Como eu não era do pedaço, ele logo observou nossa presença. Afinal, por que um casal resolveria fazer caminhadas na W3/W4 norte em plena madrugada? Mas não houve

\footnotetext{
${ }^{103}$ A Região Integrada de Desenvolvimento do Distrito Federal e Entorno (RIDE) é uma região integrada de desenvolvimento econômico, criada pela Lei Complementar Federal n. 94/98, que abrange o Distrito Federal, municípios de Goiás (Valparaíso de Goiás, Cidade Ocidental, Novo Gama, Luziânia, Águas Lindas de Goiás, Santo Antônio do Descoberto, Planaltina de Goiás, Formosa, Abadiânia, Água Fria de Goiás, Alexânia, Cabeceiras, Cocalzinho de Goiás, Corumbá de Goiás, Cristalina, Mimoso de Goiás, Padre Bernardo, Pirenópolis, Vila Boa e Vila Propício) e Minas Gerais (Unaí, Buritis e Cabeceira Grande).
} 
qualquer problema. Vi que o tal cafetão também anda bastante durante a noite na "pista", como é conhecida a ação/lugar de atividade de prostituição. Ele conversa com as prostitutas e leva algumas pelo braço, e depois elas voltam, embora eu não tenha observado qualquer violência. Além disso, ele tem um caderno ou uma prancheta preta nas mãos, imagino que seja para facilitar a contabilidade. Essas informações são as que obtive da observação do espaço. Depois de conversar com as garotas de programa, policiais e clientes, pude confirmar a atuação do cafetão, como será visto nos Capítulos 3 e 4.

\section{Notas para um dispositivo espacial da prostituição na avenida W3 norte}

A partir das observações realizadas na avenida W3 norte, é possível desenhar algumas notas sobre um dispositivo para a prostituição nesse espaço urbano de Brasília. Primeiramente, vimos que a objetivação das relações sociais no espaço urbano intensificou ainda mais a prostituição. Os "ares da cidade", além de liberdade, proporcionaram o anonimato e também a profissionalização das relações sociais. Mesmo com a oposição de grande parte das narrativas morais, médicas, jurídica, observou-se que a atividade de prostituição ganhou, no contexto assinalado, outra narrativa, aquela que a cogita como um trabalho, quantificado, qualificado e remunerado, como qualquer outra prestação de serviço liberal, embora, nesse momento inicial, possua apenas seus contornos rudimentares.

Além disso, temos que, segundo Grosz, a ideia de que ao corpo humano pode ser perfeitamente aplicado o conceito de cidade, entendido corpo humano aqui como um "processo político, lugar de inscrições, produções ou constituições sociais, políticas, culturais e geográficas" (GROSZ, 2000, p. 84). Esse corpo urbano é habitado por esses corpos humanos, como uma inter-relação ecossistêmica, de modo que "a cidade é feita e transformada em um simulacro do corpo e o corpo em reverso é 'citificado', urbanizado como um corpo distintamente metropolitano" ${ }^{104}$ (GROSZ, 1990, p. 242).

\footnotetext{
104 "This relation of introjections and projections involves a complex feedback relation in which neither the body nor its environment can be assumed to form an organically unified ecosystem. (The very notion of an ecosystem implies a kind of higher-order unity or encompassing totality that I will try to problematize in this paper.) The body and its environment, rather, produce each other as forms of the hyperreal, as modes of simulation which have overtaken and transformed whatever reality each may have had into the image of the other: the city is made and made over into the simulacrum of the body, and the body, in its turn, is transformed, 'citified', urbanized as a distinctively metropolitan body". (GROSZ, 1990, p. 242). Segue a tradução livre dessa transcrição. "Essa relação de introjeções e projeções envolve uma complexa relação de retroalimentação, na qual não se pode assumir nem que o corpo nem que o seu ambiente formam um ecossistema orgânico e unificado. (A simples noção de um ecossistema implica uma espécie de unidade de ordem superior ou de totalidade conglobante, que eu tentarei problematizar neste artigo. O corpo e seu ambiente, diversamente, produzem um ao outro como formas do hiper-real, como modos de simulação que superaram e transformaram em uma imagem um do outro, qualquer realidade que qualquer dos dois já podem ter tido: a cidade é produzida e produz um simulacro do corpo, e o corpo, por sua vez, é transformado, citificado, urbanizado como um corpo distintamente metropolitano)".
} 
Assim, essa interação entre corpos femininos e corpos urbanos, com a respectiva "citificação" dos corpos, como disse Grosz, contribui para que a atividade de prostituição, passe a ser visto como um trabalho, objetivo, profissional, quantificável e convertido em remuneração, em especial dinheiro ${ }^{105}$ (SIMMEL, 1973, p. 14).

Como se viu, Brasília, a cidade lógica, motorizada e planejada, curvou-se à funcionalidade e à apropriação de seus habitantes, que, diante da ausência das esquinas, criou o que posso chamar de um "trottoir-drive-thru", convertendo ruas e estacionamentos em vitrines para a exposição dos produtos sexuais.

Além disso, a comodidade e a conveniência dos serviços prestados nos "ambientes", que são extensões do ponto de prostituição, ou do pedaço, o território de cada prostituta, garante a integração na agenda dos clientes do prazer (SIMMEL, 1973, p.15) ${ }^{106}$, do trabalho e das justificativas para rápidas visitas às "mulheres públicas".

Contudo, essas são apenas notas a partir da observação da apropriação do espaço da pesquisa. Nos próximos capítulos adicionarei mais complexidade ao nosso dispositivo de prostituição da avenida W3 Norte.

\footnotetext{
${ }^{105}$ A economia do dinheiro domina a metrópole; ela desalojou as últimas sobrevivências da produção doméstica e a troca direta de mercadorias; ela reduz diariamente a quantidade de trabalho solicitado pelos clientes. A atitude que podemos chamar prosaicista, estilo obviamente tão intimamente inter-relacionada com a economia do dinheiro, que é dominante na metrópole, que ninguém pode dizer se foi a mentalidade intelectualística que primeiro promoveu a economia do dinheiro ou se esta última determinou a primeira. (SIMMEL, 1973, p. 14).

${ }^{106}$ Assim, a técnica da vida metropolitana e inimaginável sem a mais pontual integração de todas as atividades e relações mútuas em um calendário estável e impessoal. (...) Pontualidade, calculabilidade, exatidão, são introduzidas à força na vida pela complexidade e extensão da existência metropolitana e não estão apenas muito intimamente ligadas a sua economia do dinheiro e caráter intelectualístico. (SIMMEL, 1973, p. 15).
} 


\section{Capítulo 2. A criminalidade e a prostituição na w3 norte}

Versão Oficial - O comandante do $3^{\mathrm{a}}$ BPM da Asa Norte, tenente coronel Julio César de Oliveira, explica que na área norte do DF as mulheres são abordadas para identificação de envolvimento com outro crime vinculado à prostituição. " $A$ prostituição não é crime, mas sabe-se que as garotas geralmente trazem e levam drogas, vendem produtos ilegais e recebem objetos roubados", conclui (Jornal de Brasília, 5/12/2013) ${ }^{107}$

Nós, moradores da 713 Norte, pedimos socorro urgente às autoridades. Garotas de programa invadem nossas residências. Hoje, elas usam nossas marquises como motéis. Amanhã, elas nos expulsam de nossas casas e usam nossas camas", diz uma das faixas. Moradores associam a presença das prostitutas a problemas de violência e drogas. Antes e depois dos programas, clientes buscariam traficantes em busca de entorpecentes. E, em alguns casos, as próprias mulheres fariam uso dos produtos. (...) Para moradores e comerciantes, a situação passou dos limites. Além de afastar consumidores, a presença delas também estaria desvalorizando os imóveis da região (Jornal de Brasília, 20/4/2012) ${ }^{108}$

A rede de prostituição só aumenta desde então. A indignação dos moradores também. As moças procuram a Asa Norte por causa da grande oferta de quitinetes e do valor mais em conta do aluguel, avalia Emília Honorina, vice-presidente do Conselho de Segurança de Brasília e moradora da 716 Norte. O problema é que a atividade atrai o crime, junta bêbados, drogados e todo tipo de gente. Isso sem falar no barulho, causado pelos poucos bares da área e por algumas barraquinhas de vendedores ambulantes, opina o advogado Sérgio Paganini, presidente do Conselho Comunitário da Asa Norte. Para uma moça desacompanhada, é tarefa complicada fazer coisas simples no final da Asa Norte depois das 21h. Perdemos a liberdade de andar por aqui depois de certa hora. À noite, a rua é dessas garotas, reclama a funcionária pública Sônia Cauchioli, 56 anos, moradora da 315 Norte (Site do Departamento de DST, AIDS e Hepatites Virais, Governo Federal, 22/06/2003) ${ }^{109}$

Um grande número de casos de prostituição está localizado na Asa Norte, nas entrequadras que vão da 310 à 316 Norte. Isso tudo a céu aberto e para quem quiser ver. E não é só prostituição, vendem drogas de vários tipos e muitos usam ali mesmo. José de Araújo, contador explica que esse problema vem deste longe.

"Ninguém conseguiu coibir o avanço da droga e da prostituição nessas quadras

\footnotetext{
${ }^{107} \mathrm{http}: / /$ www.jornaldebrasilia.com.br/cidades/na-rua-a-prostituicao-tem-outra-realidade/ - Acesso em 23/9/2016.

108 http://www.jornaldebrasilia.com.br/cidades/presenca-de-garotas-de-programa-incomoda-os-moradores-do-plano-piloto/ Acesso em 23/9/2016.

${ }^{109}$ http://www.aids.gov.br/noticia/prostituicao-avanca-na-asa-norte - Acesso em 23/09/2016
} 
finais da Asa Norte. Muita gente já se mudou, mas o problema é o mesmo, agora agravado pelo crack e a policia só olha”, ressalta. Margarete Silva, musicista, mora nas quadras finais e afirma que cada dia o problema está pior. "Agora são assaltos e temos medo de sair à noite. Já fizemos reclamações variadas e nunca tivemos respaldo de nenhuma autoridade nesses anos anteriores contra a droga e prostituição nessas quadras. Ainda tem um outro problema, os moradores de rua”, aponta. (Blog DF em destaque, 30/5/2012) ${ }^{110}$

Moradores vivem atemorizados pela presença de traficantes, pela ação de bandidos que matam e arrombam prédios e pela prostituição a céu aberto. O aumento da criminalidade nas quadras do final da Asa Norte está assustando os moradores e acaba influenciando nos preços dos imóveis daquela área, o que pode ser comprovado pelos anúncios publicados nos jornais e em sites especializados. Afinal, o mapa da violência traçado pela Polícia Civil indica a presença de tráfico de drogas nas proximidades das comerciais da 312 a 315 , arrombamentos de apartamentos das 400, a prostituição entre a W3 Norte, da 712 a 715, passando pela 315 e chegando às 900, assaltos, roubo de carros, assim como casos de morte violenta. (Jornal Coletivo, 21/11/2012) ${ }^{\mathbf{1 1 1}}$

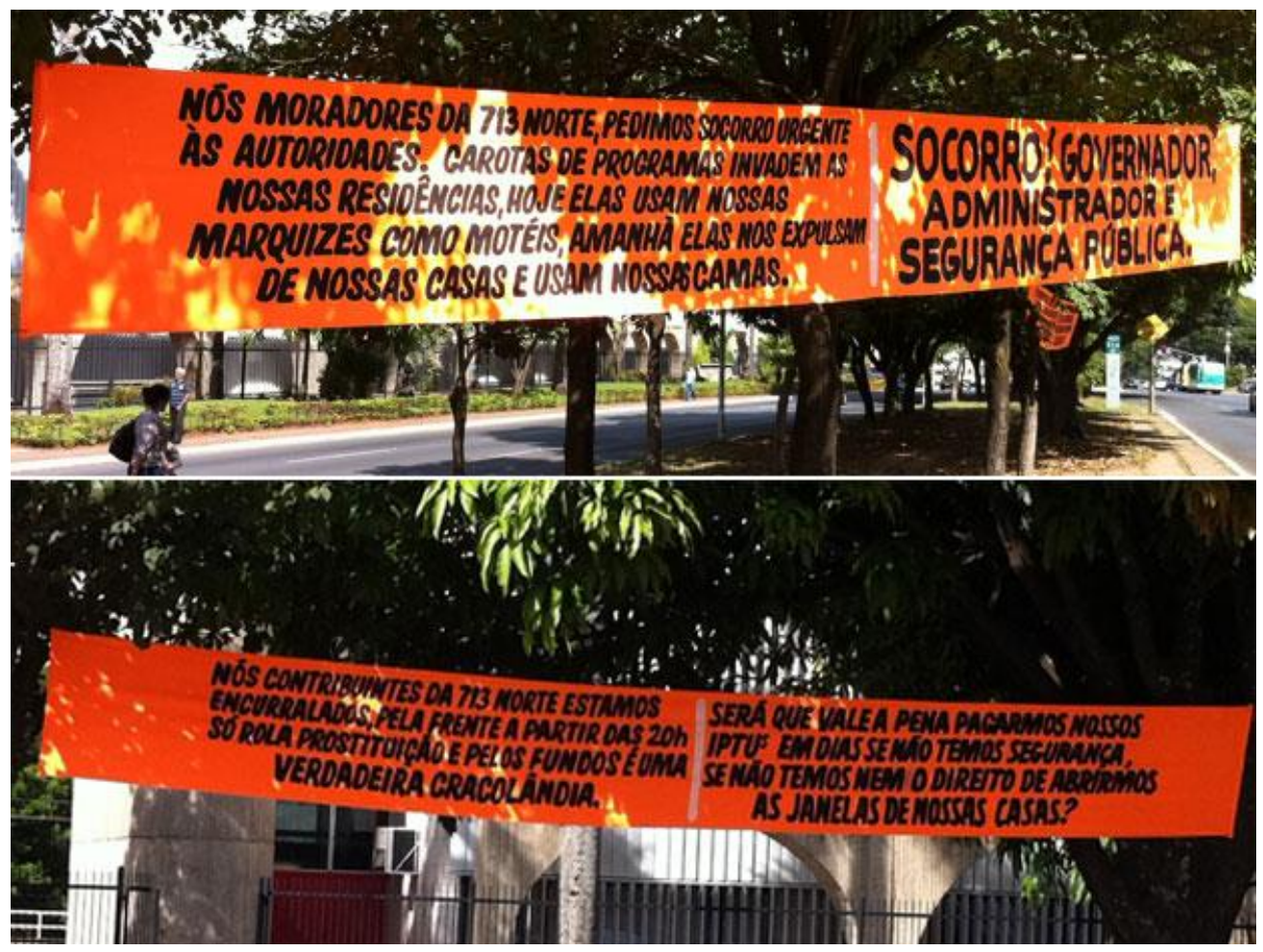

Figura 3. Faixas de protesto dos moradores da 715 norte para protestar contra a presença das prostitutas. Fonte: Jornal de Brasília.

\footnotetext{
${ }^{110} \mathrm{http}: / /$ dfdestaque.blogspot.com.br/2012/05/elas-estao-por-toda-parte.html - Acesso em 23/09/2016

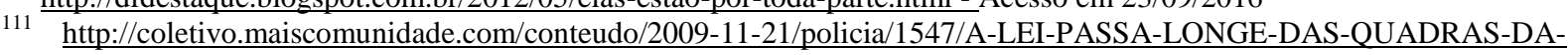
ASA-NORTE.pnhtml - Acesso em 23/09/2016
} 


\section{A prostituição, a cidade e a criminalidade}

O ambiente profissional de "putas" é criminógeno? A resposta é afirmativa se tomarmos em conta algumas das representações sociais reproduzidas por parte dos moradores das cercanias da Avenida W3 norte, reproduzidos nos recortes de jornais acima transcritos, os quais associam diretamente a atividade de prostituição ao aumento da criminalidade referente a tráfico de drogas, roubos, furtos, e até homicídios.

Mas será mesmo que podemos dizer que o exercício livre da prostituição constitui uma das causas da criminalidade urbana? Embora essa seja uma questão importante, não há muitas pesquisas destinadas a estudá-la especificamente, o que reforça ainda mais a necessidade de discussão sobre o tema.

Contudo, tem-se que, ainda que objetivamente inexista essa relação necessária entre prostituição e criminalidade, no imaginário social, ela está presente. Ambos são considerados "anomalias sociais" ou "desvio de condutas", objetos do controle social em maior ou menor grau. Aqueles que recebem com sucesso o rótulo de "criminosos" ou "putas" têm seu espaço físico e simbólico segregado na cidade e na sociedade.

Como vimos na introdução, Becker (2008, p.22) chegou a uma interessante definição que nos ajuda a refletir sobre a resposta para a questão: “O desvio não é uma qualidade do ato que a pessoa comete, mas uma consequência da aplicação por outros de regras e sanções a um infrator. O desviante é alguém a quem esse rótulo foi aplicado com sucesso; o comportamento desviante é aquele que as pessoas rotulam como tal".

Desse modo, ele considera que quem define o que é o desvio ou quem é a pessoa desviante não é o ato ou a conduta praticada pela pessoa, mas a reação dos outros diante dessa conduta. É essa reação que implica, ou não, a aplicação de regras ou sanções ao infrator. De acordo com essa resposta social, uma pessoa pode ser considerada como desviante mesmo sem ter cometido qualquer ato efetivamente infrator, tendo como base, por exemplo, o seu estilo de vida. A partir da mesma ideia central de desvio como reação dos outros a um comportamento ou conduta infratora, chega-se também à conclusão de que o conceito do termo desviante também não depende da própria autoimagem da pessoa como tal, mas apenas da aplicação com sucesso desse rótulo.

A teoria do desvio pode ser perfeitamente aplicável à atividade de prostituição. Como já abordado anteriormente, várias foram as narrativas - morais, religiosas, médicas, jurídicas e sociais - que trataram de atribuir à atividade de prostituição esse rótulo de conduta desviante, uma vez que as profissionais do sexo eram tidas como pessoas abjetas, desviantes da 
expectativa social de conduta que é reservada a um cidadão exemplar, e em especial às mulheres. E essas narrativas, cada uma ao seu modo, foram encampadas por grande parte da sociedade.

Segundo Goffman, o termo estigma é um atributo profundamente depreciativo utilizado no âmbito do espaço público, e não na intimidade. Assim, “a área de manipulação do estigma, então, pode ser considerada como algo que pertence fundamentalmente à vida pública, ao contato entre estranhos ou simples conhecidos, colocando-se no extremo de um continuum cujo polo oposto é a intimidade" (GOFFMAN, 1988).

No caso da imposição do rótulo ou do estigma de desviante às "mulheres públicas" que por si só já são consideradas públicas, sem qualquer direito ao exercício de sua identidade ou intimidade -, esse processo se dá de forma ainda mais forte. Percebidas como imorais, um perigo e uma ameaça à feminilidade tida como 'normal', as prostitutas são, frequentemente, excluídas socialmente, marginalizadas e sofrem o estigma de puta” (RODRIGUES, 2007).

Outra teoria interessante que pode auxiliar na compreensão dessa vinculação direta entre a atividade de prostituição e a criminalidade é a ideia de o desvio ser tratado como um master status, ou seja, uma característica, ou melhor, um rótulo ou um estigma que é atribuído a uma pessoa que serve como parâmetro para prever todas as demais características desse indivíduo. Everett Hughes trabalhou bem essa ideia e, segundo ele, esse status é definido, em sentido estrito, como a posição social ocupada por alguém, do qual resulta direitos, limitações de direitos e obrigações (HUGHES, 1945).

Um status traduz, por exemplo, a condição ou ideia de ser médico, advogado, homem, mulher, negro, branco, pobre, filho, mãe, cidadão, estrangeiro, criminoso, entre outros. Entre essas categorias, Hughes observa que há aquelas em que se pode identificar um traço fundamental que serve para distinguir pessoas que são classificadas como tal daquelas que não possuem tais características. Por exemplo, para ser um médico, é bastante o preenchimento de certos requisitos e licença para exercer a medicina, não importando suas características físicas, sociais e seu passado. No entanto, como destaca Hughes em relação à sociedade norte-americana, espera-se que um médico seja da classe média alta, branco do sexo masculino e protestante. Assim, pode-se dizer que alguém que possui uma característica chave, que pode ser considerada um status principal, gera a expectativa informal de possuir também outras características secundárias, consideradas por Hughes, como status auxiliares. 
Segundo o autor, no caso do médico, são status auxiliares a expectativa de ser homem, branco, da classe média ${ }^{112}$.

No caso de um status principal ser prostituta, contudo, tem-se como status auxiliares as pessoas serem marginalizadas, clandestinas, com baixo nível de educação e escolaridade, criminosas, disseminadora de doenças, conforme vimos nas reportagens dos jornais de Brasília, acima apostos.

A etiqueta ou o rótulo do desvio traz consigo muitas conotações que especificam traços auxiliares esperadas de qualquer pessoa que carregue o mesmo rótulo. Assim, no caso de a etiqueta ser criminoso, espera-se de um homem condenado por furto, e, logo rotulado como criminoso, que ele irá furtar outras casas, e cometer outros tipos de crime, uma vez que já ele demonstrou não ter respeito pela lei. No caso de a etiqueta do desvio ser prostituta, espera-se que sua palavra não tenha a mesma validade perante os órgãos do Estado que a das demais pessoas, em razão de seu modo de vida ${ }^{113}$.

As reflexões realizadas pelos sociólogos do desvio até então apresentadas traduzem a construção de um possível conceito do termo desvio e suas consequências, o qual não está relacionado diretamente com o fato infrator em si ou a conduta do indivíduo, mas principalmente com a reação do meio social quanto à pessoa que infringiu a regra, bem como às condições em que ela o fez. No caso da atividade de prostituição, é possível levantar a hipótese de que a categoria prostituta seja, conforme a teorização de Hughes, um master status, ou seja, o "ser prostituta" se torna a característica mais importante da pessoa e cria expectativas em relação a todas as suas outras qualidades, e que tal rótulo é aplicado a ela, em razão de ela descumprir determinado conjunto de regras sociais.

\begin{abstract}
Pelas observações e pela bibliografia extensa sobre o tema, é completamente plausível afirmar que junto do desempenho da profissão vem um rótulo totalizante que entende as prostitutas como mulheres promíscuas, mentirosa, sedutoras, escandalosas, violentas e fonte de doenças. (CAPELA, 2013).
\end{abstract}

Outro suporte que auxilia a reflexão sobre as narrativas relacionadas à justificação dessa relação entre a prostituição e a criminalidade, nos seus eventuais papéis de autores, vítimas e testemunhas, é a teoria das associações diferenciais. Em síntese, ela defende que o desvio

\footnotetext{
${ }^{112}$ HUGHES ainda apresenta outra reflexão acerca da existência das categorias de status principal e status subordinado. Segundo ele, existem certos status no meio social que se sobrepõem a outros, ou seja, ele determina as características de outros status relacionados àquela pessoa. Por exemplo, em alguns contextos culturais, o status correspondente à raça é extremamente forte, de modo que uma pessoa é negra, antes de ser médica ou mulher. Nesse sentido, HUGHES defende que, no caso do criminoso, em certos tipos de crime, o rótulo assume a posição de status preponderante, subordinando todas as características especificas da pessoa que recebe o predicativo.

${ }^{113}$ A propósito, tratei brevemente sobre o valor da palavra da prostituta nos processos judiciais nas narrativas jurídicas sobre a prostituição no capítulo introdutório.
} 
sistemático é aprendido pela pessoa em associação direta ou indireta com outros que já praticaram um comportamento desviante. Segundo Sutherland (1940), o "fato de que uma pessoa torne-se ou não um criminoso é determinado, em larga medida, pelo grau relativo de frequência e de intensidade de suas relações com os dois tipos de comportamento. Isto pode ser chamado de processo de associação diferencial".

A partir dessa perspectiva, o comportamento desviante não seria determinado geneticamente, nem seria produzido por problemas na personalidade, e nem pela pobreza. Trata-se, sim, de um comportamento aprendido, da mesma maneira que outros tipos de comportamentos são aprendidos, por intermédio da interação com outras pessoas no processo comunicativo $^{114}$. A parte fundamental desse aprendizado se desenvolve nos grupos pessoais íntimos, já que a influência dos contatos impessoais, como os meios de comunicação, é pouco importante para Sutherland (ANITUA, 2008).

No caso da prostituta, ao desafiar ou desviar por completo do "dispositivo de sexualidade", que é o esperado de uma mulher "normal", ela afrontaria uma rede de significados, uma rede de controles, capazes de qualificar sua conduta negativamente, de considerá-la desviante. Mostra-se interessante que, analisando sua atividade longe dos parâmetros morais, religiosos, médicos e jurídicos, a prostituta "venderia" apenas suas habilidades sexuais/conhecimentos específicos, assim como uma professora "vende" conhecimentos específicos ao lecionar uma aula, ou uma cabelereira "vende" suas habilidades manuais/conhecimentos específicos ao realizar um corte de cabelo. Ou seja, a prostituta somente é considerada uma desviante a partir de uma interação de sua atividade com as reações sociais que são conduzidas pelas reiteradas e cristalizadas representações sociais reunidas nas narrativas moral, religiosa, médica, jurídica e social.

Abjeta e segregada simbolicamente de grande parte dos níveis de interação social (moral, sexual, religiosa, médica, espacial, legal), a atividade de prostituição e a criminalidade a ela associada apresentam-se em uma rede de elementos heterogêneos e, amiúde, opostos entre si, e forças que interagem, determinando-se e disputando influência.

Finalmente, o melhor entendimento dessa relação entre a prostituição e a criminalidade depende de narrativas, para além daquelas já mencionadas. Existem diversos caminhos para tanto, em especial no que tange à prostituição de rua na W3 norte. Um deles é o estudo dos

\footnotetext{
${ }^{114}$ Essa perspectiva de Sutherland agrega bastante valor à reflexão de como um sujeito desviante consegue ultrapassar as barreiras do controle da conduta padrão e permanecer à margem. De fato, o desviante não foge à cultura do controle em si, ele apenas foge ao controle que tem como o parâmetro o padrão. Mesmo para integrar um grupo de "desviantes", ele aprende novas condutas, padrões, hábitos, trejeitos, típicas daquele grupo, os quais também impõe outro tipo de controle. No caso da prostituição, uma mulher que é prostituta também, de certa forma, deverá submeter-se a outro tipo de controle, ao controle do padrão de ser prostituta, comportar-se como tal e respeitar os espaços das outras prostitutas.
} 
casos que chegam ao conhecimento do Estado por meio dos registros dos boletins de ocorrência na área mencionada, relacionados à prostituição e à criminalidade a ela envolvida.

\section{O registro das ocorrências policiais na área da $\mathrm{W} 3$ norte}

Como se viu, no imaginário social, há certa relação entre a prostituição e criminalidade, seja pela imposição de um master status à prostituta, que geraria a expectativa de ela estar ligada a condutas desviantes, inclusive crimes, seja pelo o ambiente urbano segregado em que esses tipos de serviços sexuais são prestados.

Mas será mesmo que podemos observar essa relação nas ocorrências policiais que tenham alguma relação com a prostituição? Em que condição e em que tipos de crimes figuram as prostitutas nas ocorrências policiais da área da Avenida W3 Norte?

Perguntas fáceis e difíceis de responder ao mesmo tempo. Fáceis, porque basta analisar uma amostra e categorizar essa relação para compreendê-la melhor. Difíceis porque não se pode dizer que a partir apenas da análise de ocorrências policiais de certo período podemos dar conta de toda essa complexa relação, pois, mesmo "dados empíricos" convertidos em estatísticas criminais, por "força dos números", estão repletos de representações sociais e seletividade de uma série de personagens, a própria prostituta e o cliente que escolhem ou não noticiar o fato, o policial militar da rua que conduz, ou não, o conflito à delegacia de polícia, o agente de polícia civil responsável por reduzir a termo esse conflito, o delegado de polícia, incumbido da classificação da conduta como crime ou não. Dessa forma, não só a existência do registro de um boletim de ocorrência depende de uma série de fatores como também a forma em que ele é produzido.

Nesse contexto, a aparente objetividade de uma "estatística criminal" enfrenta uma série de subjetividades que devem ser consideradas quando da análise de seus conteúdos. Da mesma forma que um registro tem um teor a ser analisado, um não registro, ou uma subnotificação, também tem sua significação. Contudo, a importância dessas subjetividades não impede a análise desses importantes indicativos de apreensões de versões da realidade. Se assim fosse, nenhuma pesquisa poderia ser desenvolvida e nosso entendimento sobre as relações sociais ficaria muito diminuído.

Feitos esses esclarecimentos, procedi à análise de ocorrências policiais registradas referentes à área da W3 norte, entre os anos de 2010 a 2015 (POR QUE ESSE PERÍODO?), e relacionadas de alguma forma com a atividade de prostituição. O método utilizado tanto para 
a constituição e análise do espaço amostral foi da análise de conteúdo, que, em síntese, pode ser considerada, segundo a definição de J. Bardin, como

um conjunto de técnicas de análises de comunicações, que utiliza procedimentos sistemáticos e objetivos de descrição do conteúdo das mensagens... A intenção da análise de conteúdo é a inferência de conhecimentos relativos às condições de produção e de recepção das mensagens, inferência esta que recorre a indicadores (qualitativos, ou não). (FRANCO, 2008, p. 24).

O marco teórico da análise de conteúdo tem como base a teoria da comunicação, e seu ponto de partida é a mensagem, seja ela verbal (oral ou escrita), gestual, ou documental. E essa mensagem é a manifestação das representações sociais, nossas elaborações mentais construídas socialmente a respeito de um assunto, processos sociocognitivos, uma intercessão entre a psicologia e a sociologia, como já foi tratado na introdução desse trabalho ${ }^{115}$.

Nesse contexto, tomam-se os boletins de ocorrências como mensagens comunicativas de representações sociais levadas ao registro na delegacia de polícia pelos envolvidos (autores, vítimas, testemunhas, policiais militares) e reduzidas a termo pelos policiais civis. O conteúdo dessas ocorrências, relacionado à atividade de prostituição, será o objeto de nossa análise, lembrando que ele representa apenas uma versão, dessa complexa realidade.

O sistema utilizado para o registro de ocorrência da Polícia Civil do Distrito Federal é o Millenium, o qual foi desenvolvido pela própria instituição ${ }^{116}$. Nesse sistema, o boletim de ocorrência possui, basicamente, duas áreas para o registro (Anexo 1). A primeira consiste em uma parte objetiva e é dedicada à parte de identificação dos envolvidos nos fatos, referente ao nome, endereço, qualificação profissional, contatos, data, hora e local dos fatos. Nessa fase, os agentes da Polícia Civil preenchem os dados no formulário de registro da ocorrência assinalando opções, com pouca liberdade para inserção livre de dados. Por sua vez, a segunda parte consiste no detalhamento, mediante a escrita de um breve resumo dos fatos, no campo destinado ao histórico da ocorrência policial. Nessa etapa, há mais liberdade, em tese, para o agente de polícia narrar os fatos com maior riqueza de detalhes, esclarecendo melhor as motivações e circunstâncias do fato supostamente criminal relatado.

\footnotetext{
115 "Para compreender melhor a relação que se estabelece entre o comportamento humano e as representações sociais, devemos partir da análise do conteúdo das representações e considerar, conjuntamente, os afetos, as condutas, os modos como os atores sociais compartilham crenças, valores, perspectivas futuras e experiências afetivas e sociais". (FRANCO, 2008, p. 12)

${ }^{116}$ O projeto Millenium está em constante desenvolvimento pelos técnicos PCDF desde 1999, e alcança 4 sistemas internos, referentes ao registro de ocorrências nas delegacias, às denúncias anônimas da comunidade, ao sistema protocolo dos procedimentos administrativos e ao sistema PROCED, que se refere aos procedimentos criminais. $\mathrm{O}$ sistema de registro de ocorrências utilizado nesta pesquisa é proveniente da base de dados do antigo SIOCOP (Sistema de Controle de Ocorrências Policiais), cuja base foi substituída pelo projeto Millenium desde dezembro de 1999.
} 
Na parte objetiva dos formulários dos boletins de ocorrência da Polícia Civil do Distrito Federal, não há qualquer campo destinado ao detalhamento de circunstâncias referentes à prática de crimes associados à atividade de prostituição. ${ }^{117}$

Assim, para a seleção dos fatos narrados como criminosos associados à atividade de prostituição, elegeu-se o critério de pesquisa no sistema Millenium por meio da "pesquisa no histórico da ocorrência", o qual consiste na seleção de um lapso temporal, o termo da busca e a seleção da Delegacia de Polícia onde foi efetuado o registro.

Considerando que "produzir inferências a partir de indicadores (quantitativos ou não) é a razão de ser da análise de conteúdo" (FRANCO, 2008, p.29), que tem como bases da préanálise, a leitura flutuante e a escolha de documentos, conforme as regras da exaustividade e representatividade ${ }^{118}$, depois dessa fase preliminar, elegi como categorias de análise ou indicadores, que são os termos "prostituição", "prostituta", "garota de programa", "cafetão", "travesti" e "cafetina", nos históricos das ocorrências.

Essa eleição teve como base uma pesquisa prévia em vários boletins de ocorrência, nos quais, percebi que esses termos eram mais recorrentes sobre o tema, e também o resultado de entrevistas semiestruturadas (Anexo 3) que fiz com alguns agentes de polícia responsáveis pelos registros das ocorrências ${ }^{119}$. Nessas entrevistas, por exemplo, eles mencionaram, em grande medida, esses termos como aqueles utilizados para a confecção de uma ocorrência policial envolvendo a atividade de prostituição.

Para a limitação geográfica do objeto do estudo, restringi os boletins apenas à área da avenida W3 norte, de forma que, uma vez selecionados aqueles em razão dos indicadores acima mencionados e pela área do fato, Asa Norte, seria feita a limpeza dos dados para filtrar somente os fatos que guardasse alguma relação com a avenida W3 norte.

Quanto ao lapso temporal, elegeram-se os últimos cinco anos, a fim de buscar um suficiente espaço amostral de casos, escolhendo-se, de forma aleatória, a data inicial de $1 / 1 / 2010$, e final de 31/12/2015.

Para organizar as informações dos boletins de ocorrência selecionados na busca pelo histórico no sistema Millenium, foi construída uma tabela com seis indicadores: 1) a natureza

\footnotetext{
${ }^{117}$ Naturalmente, as condutas referentes ao favorecimento ou à exploração sexual, na qual se considera qualquer vitimização do indivíduo voltada a tirar proveito, abusar, lucrar, mediante fraude ou engodo de pessoas (NUCCI, 2009, p. 57), que são consideradas como crimes, possuem um campo específico no boletim de ocorrência, correspondente à "natureza da ocorrência". Contudo, as condutas criminosas associadas à atividade de prostituição não são objetivamente explicitados nos campos objetivos de preenchimento do registro policial.

${ }_{118}$ Segundo BARDIN, a leitura flutuante seria o contato prévio com os documentos da análise, para entendimento prévio, impressões e hipóteses, a fim de escolher e filtrá-los, conforme a ideia da construção de um espaço amostral exaustivo e representativo do universo inicial. (FRANCO, 2008, p. 52 e 53).

${ }^{119}$ Realizei três entrevistas com agentes de polícia da Polícia Civil do Distrito Federal, órgão responsável pelos registros de ocorrências nas delegacias da Asa Norte, cujos perfis encontram-se no Anexo 2.
} 
criminal a ele atribuída $\left.{ }^{120}, 2\right)$ a data do fato, 3) o endereço do fato, 4) a idade do profissional do $\operatorname{sexo}^{121}, 5$ ) a participação do profissional do sexo e 6) o gênero do profissional do sexo.

O primeiro indicador "natureza" se refere a um critério objetivo de classificação da conduta narrada, previamente determinado pelo sistema Millenium, segundo critérios próprios definidos pelo setor de análise criminal da Polícia Civil do Distrito Federal (PCDF), visando fins estatísticos. Assim, não necessariamente, as naturezas das ocorrências correspondem ao mesmo tipo penal, definido no Código Penal brasileiro e leis penais extravagantes. ${ }^{122}$

Para o conteúdo dos indicadores referentes à data e ao endereço do fato foram consideradas as informações fornecidas pelo (a) comunicante da ocorrência.

Quanto ao indicador “participação do profissional do sexo nos fatos”, em princípio, foram empregadas as categorias de autor, vítima e testemunha, de forma que, ao ler a dinâmica dos fatos, classificava-se o profissional do sexo nessa tipologia.

$\mathrm{O}$ indicador referente ao gênero destinou-se a identificar o gênero do profissional do sexo envolvido na ocorrência policial: feminino ou travesti.

Finalmente, o indicador "idade" refere-se à idade do profissional do sexo relacionado na ocorrência na data dos fatos.

Ressalta-se que, naturalmente, por se tratar de procedimentos sigilosos, o nome dos envolvidos a qualquer título foi e será mantido em segredo.

Após a fase da coleta, os dados foram organizados de forma a facilitar sua análise. Procedeu-se à uniformização dos endereços e de eventuais informações dispersas e depois foi realizada a análise de cada indicador já mencionado.

Tanto para a colheita quanto para a análise dos dados, realizei entrevistas com os agentes de polícias e delegadas da Delegacia de Atendimento à Mulher (DEAM) para entender e interpretar os dados colhidos, cujo conteúdo será exposto, a seguir, na apresentação dos resultados da análise de conteúdo das ocorrências em questão.

\footnotetext{
${ }^{120} \mathrm{O}$ 'natureza criminal' da ocorrência relaciona-se com o tipo de crime narrado no registro.

${ }^{121}$ Como visto, para esse trabalho, a figura do travesti, que assume o fenótipo feminino, mas preserva a genitália masculina, será considerada igualmente como prostituta, apesar de não lhe negar suas peculiaridades, que, como ressaltou Hélio Silva, "o termo travesti se aplica a um universo complexo e heterogêneo composto de intelectuais, artistas, prostitutos, transformistas ou transexuais. Esse rico universo comporta, inclusive, descontinuidades irreconciliáveis. Transformistas que não toleram travestis, travestis que nem a autenticidade do transformista, artistas que desprezam os travestis de rua - ou de pista. A menção aqui não é a brigas entre pessoas, incompatibilidades temperamentais, mas à própria negação de subcategorias no interior do arco de possiblidades dessa coletividade (SILVA, 2007, p. 29).

${ }^{122}$ Por exemplo, há ocorrências no sistema Millenium de "furto de bicicleta", "furto de veículo", "furto de celular", sendo que no Código Penal, furto é uma única conduta, independentemente do objeto da subtração.
} 


\section{A análise das ocorrências policiais na área da W3 norte}

Depois de realizada a pesquisa dos termos de busca "prostituição", "prostituta", "garota de programa", "cafetão", "travesti" e "cafetina" nos históricos das ocorrências policiais entre as datas de 01/01/2010 a 31/12/2015, referentes a fatos ocorridos no bairro Asa Norte, cheguei a 382 registros realizados na $2^{\mathrm{a}} \mathrm{DP}$, DEAM e demais delegacias do DF. ${ }^{123}$

Logo em seguida, procedeu-se à limpeza espacial e material dos dados. A depuração espacial referiu-se a filtrar os registros referentes apenas ao território da avenida W3 norte, área de interesse da pesquisa, já que a Asa Norte abrange uma área extensa, como, por exemplo, a Universidade de Brasília, a avenida L2, e a Granja do Torto.

A limpeza material consistiu em filtrar os boletins a fim de retirar fatos não relacionados à atividade de prostituição, apesar de os termos citados de busca terem aparecido em seus históricos. Isso porque se percebeu que, em vários registros, as palavras "prostituta" ou "prostituição" eram utilizadas na prática de crimes contra a honra (injúria e difamação), na grande maioria dos casos em situações de violência doméstica, nas quais havia a manifesta intenção de injuriar ou menosprezar a vítima atribuindo-lhe o estigma de prostituta. Embora tal dado não seja objeto direto do presente trabalho, esse grande número de casos leva a duas reflexões que corroboram a marginalização e a estigmatização que os profissionais do sexo sofrem por conta de sua atividade.

Primeiramente, há a deterioração moral decorrente da condição de ser prostituta, e não simplesmente uma profissional que trabalha com o sexo. Tal depreciação refere-se à frustação das expectativas do papel social, em quase todos os casos, da mulher, ao realizar a atividade de prostituição. Assim, ser prostituta é um atributo negativo, como ser "ladra", "criminosa", "safada", utilizado comumente pelos companheiros/esposos para desqualificar o comportamento social e familiar de suas companheiras/esposas. Um estudo recente do Departamento de Psicologia da UnB mostrou que o xingamento mais utilizado contra as mulheres é de "puta" e para homens, "viado", o que confirma essa representação social de menos valia ligada à atividade de prostituição em relação às mulheres ${ }^{124}$.

\footnotetext{
${ }^{123}$ Em Brasília, não há qualquer restrição de registros de ocorrências policiais por área, de forma que qualquer pessoa pode ir a qualquer delegacia do Distrito Federal registrar um fato independentemente de onde ele ocorreu. Contudo, pela divisão administrativa do território, ele será apurado na respectiva área da delegacia do ocorrido.

${ }^{124}$ Pesquisa realizada sobre a coordenação da Prof. Dra. Valeska Zanello, do Departamento de Psicologia da UnB. Fonte: http://sites.correioweb.com.br/app/50,114/2015/06/12/noticia_saudeplena,153670/pesquisa-mostra-que-palavroes-ofendemhomens-e-mulheres-de-forma-difer.shtml Acesso em 26/9/2016.

Valeska Zanello (IESB) Xingamento; Erotismo; Subjetividade ST 33 - Subjetividade, gênero e sexualidade.
} 
Em segundo lugar, tal uso do termo "prostituta" indica que os autores desses xingamentos não consideram a prostituição como uma profissão como outra qualquer, pois, do contrário, não utilizariam esse termo como um ataque verbal. Afinal, na leitura dos registros policiais selecionados, não se observou como injúria frases como "sua professora", "sua médica", "sua funcionária pública”. O grau de cristalização dessa representação social negativa constitui uma forte barreira no país à formalização, no mercado de trabalho, da atividade de prostituição, como aconteceu em países como Alemanha e Holanda ${ }^{125}$, atribuindo dignidade e respeito a essas profissionais.

Ademais, observa-se que o termo prostituta refere-se diretamente a uma suposta degradação da condição de mulher, principalmente quando se considera a sociedade machista brasileira. Na mais comum representação social machista, a prostituta frustra as expectativas de mulher ideal, a qual deve ser "bela, recatada e do lar" e, portanto, sua condição reverte-se em desprezo e xingamentos. Bem lembrou Goffman quando tratou sobre o comportamento em lugares públicos que a prostituta de rua seria um ótimo exemplo de regras comunicativas sobre abordagens nas ruas, ressaltando que seus "olhares e gracejos" para atrair clientes "nos dizem precisamente como todas as outras mulheres devem se cuidar para não se comportar". (GOFFMAN, 2010, p. 156).

Dessa forma, ao final dessa segunda filtragem, nosso espaço amostral caiu para 121 registros policiais, contendo os termos de busca em questão, no período considerado e na região da Avenida W3 Norte. ${ }^{126}$ É importante esclarecer que cada um desses registros pode reportar tanto uma pluralidade de condutas definidas como crime pela lei brasileira, quanto simples condutas administrativas como apreensão de bens irregulares, perdidos, ou mesmo de entorpecentes não vinculados a qualquer autor específico.

Os 121 registros referem-se a 26 modalidades ou naturezas de ocorrências, que, como dito, não necessariamente correspondem a condutas definidas como crime. Para facilitar a

\footnotetext{
${ }^{125}$ A título de exemplo, pode-se dizer que há, basicamente, quatro modelos adotados pelos países no tratamento da atividade de prostituição: 1) atividade de prostituição totalmente ilegal, tanto referente ao (à) profissional do sexo quanto a seu cliente (maior parte dos condados dos Estados Unidos da América, China, Egito); 2) atividade de prostituição legal, mas desestimulada pela ilegalidade do uso do serviço (Suécia, Noruega, Islândia); 3) atividade de prostituição legal, mas não regulamentada (Brasil, Canadá, Itália); 4) atividade de prostituição legal e regulamentada (Holanda, Alemanha, Turquia, México, Senegal e maior parte da América Latina). Fonte: http://www.state.gov/j/drl/rls/hrrpt/2008/index.htm, acesso em 25/09/2016.

${ }^{126}$ Para efeitos comparativos, verificou-se que, no período considerado para o trabalho, 01/01/2010 a 31/12/2015, foram registradas 79.267 ocorrências policiais na $2^{\mathrm{a}}$ DP e 21.802 DEAM. Ressalte-se que nem todas as ocorrências registradas nas delegacias de polícia do Distrito Federal possuem natureza criminal, podendo assumir as categorias de acidente de trânsito com ou sem vítima e extravio. Assim, o total de ocorrências apenas do tipo criminal no período considerado na $2^{\mathrm{a}}$ DP foi de 48.421 e na DEAM 20.750.
} 
análise, essas naturezas de registros foram divididas em três grupos ${ }^{127}$ : 1) crimes com violência (ameaça, busca de cadáver, disparo de arma de fogo, estupro, homicídio, roubo, latrocínio, perigo para vida de outrem, incêndio, vias de fato e lesão corporal, inclusive no contexto da violência doméstica); 2) crimes patrimoniais sem violência (dano, desacordo comercial, estelionato, furto); 3) crimes contra ordem pública, honra e outros (abandono de incapaz, apreensão de bens irregulares, apreensão de possível substancia entorpecente, calúnia, casa de prostituição, desobediência, injúria, tráfico de entorpecentes, porte de droga ou entorpecentes, perturbação do sossego ou da tranquilidade). A tabela abaixo indica o grupo, o tipo de registro e sua respectiva frequência na amostra:

Tabela 1. Tipos de crimes e quantidade de ocorrências

\begin{tabular}{|c|c|c|c|c|}
\hline Grupo & Tipo de registro & Freq. & Tipo de registro & Freq. \\
\hline \multirow{6}{*}{$\begin{array}{l}\text { Crimes com } \\
\text { violência } \\
(\text { Total }-74)\end{array}$} & Estupro & 4 & Vias de fato & 3 \\
\hline & Ameaça & 29 & Incêndio & 1 \\
\hline & Disparo de arma de fogo & 1 & Busca de cadáver & 1 \\
\hline & Lesão corporal & 12 & Homicídio & 3 \\
\hline & Contexto de violência doméstica & 3 & Homicídio tentado (sem morte) & 4 \\
\hline & Perigo para vida de outrem & 1 & Roubo & 12 \\
\hline \multirow{2}{*}{$\begin{array}{c}\text { Crimes } \\
\text { patrimoniais } \\
(\text { Total }-25)\end{array}$} & Dano & 4 & Estelionato & 2 \\
\hline & Desacordo comercial & 3 & Furto & 16 \\
\hline \multirow{5}{*}{$\begin{array}{c}\text { Crimes contra } \\
\text { ordem } \\
\text { pública, honra } \\
\text { e outros } \\
\text { (Total }-37 \text { ) }\end{array}$} & Casa de Prostituição & 3 & Injúria & 9 \\
\hline & Abandono de incapaz & 1 & Tráfico de entorpecentes & 5 \\
\hline & Desobediência & 2 & Calúnia & 2 \\
\hline & Apreensão de bens irregulares & 1 & Porte de droga ou entorpecente & 5 \\
\hline & $\begin{array}{l}\text { Perturbação do sossego ou da } \\
\text { tranquilidade }\end{array}$ & 8 & $\begin{array}{l}\text { Apreensão de possível } \\
\text { substância entorpecente }\end{array}$ & 1 \\
\hline
\end{tabular}

\footnotetext{
${ }^{127}$ Ressalta-se que a presente divisão em grupos não contempla a classificação do Código Penal dos crimes conforme o bem jurídico protegido, uma vez que o roubo, por exemplo, na legislação penal é considerado crime patrimonial pelo seu elemento objetivo de violência.
} 


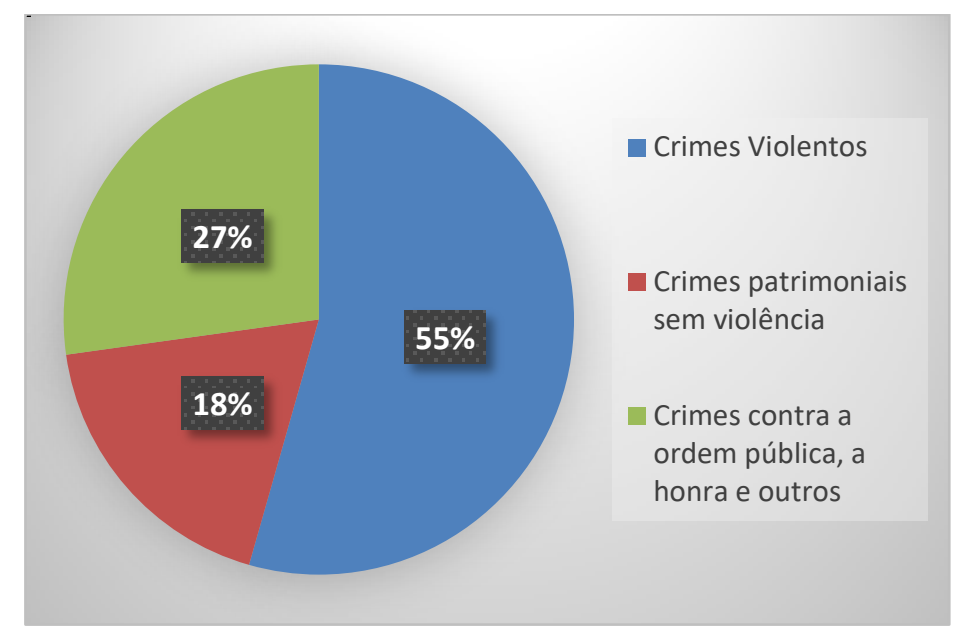

Gráfico 1. Tipos de crimes e quantidade de ocorrências

Se considerarmos que a amostra de 121 casos abrange um período de tempo de cinco anos, temos por ano 24,2 registros de ocorrências policiais relacionadas de alguma forma com a atividade de prostituição na avenida W3 norte, e, 14,8 registros classificados no grupo de crimes violentos, ou seja, 1,3 por mês.

Tais "números" não são suficientes para, por si só, explicar a cruzada moral contra as prostitutas na avenida W3 norte, noticiada por meio das reportagens nos meios de comunicação de Brasília, algumas delas reproduzidas no início deste capítulo. Assim, nessa primeira aproximação, a insegurança urbana teria pouca ou quase alguma relação com uma eventual criminalidade associada à prostituição.

Contudo, nesse contexto, há dois fatores adicionais a serem discutidos. Um deles é a ideia de metaforização ou de deslocamento, que são conceitos desenvolvidos para compreender o sentimento de medo do crime em uma determinada comunidade (MACHADO, 2004, p. 89). O medo seria uma metáfora e um processo de gestão de outras ansiedades mais fundamentais. "Essas ansiedades, decorrentes de problemas sociais mais profundos, irresolúveis ou ameaçadores para o status quo, são, portanto, canalizadas e focalizadas na figura do crime de rua e do criminoso. Esse tornar-se-ia um símbolo útil para condensar uma variedade de stressores nas nossas vidas" (MACHADO, 2004, p. 90).

No caso das manifestações dos moradores da Asa Norte, a partir dos dizeres "Nós, moradores da 713 Norte, pedimos socorro urgente às autoridades. Garotas de programa invadem nossas residências. Hoje, elas usam nossas marquises como motéis. Amanhã, elas nos expulsam de nossas casas e usam nossas camas ${ }^{128}$, percebe-se, claramente, que essas ansiedades não decorrem apenas da preocupação com segurança pública, mas também com a

${ }^{128}$ http://www.jornaldebrasilia.com.br/cidades/presenca-de-garotas-de-programa-incomoda-os-moradores-do-plano-piloto/ Acesso em 23/9/2016. 
ofensa ao dispositivo de sexualidade. São ansiedades de incerteza moral, diante das várias transformações sociais na questão de gênero e da sexualidade, na ocupação dos espaços públicos, na nova significação e configuração do conceito de família (MACHADO, 2004, p. 94), que se traduzem em medo da rua, em medo do crime ${ }^{129}$.

Nesse contexto, crimes violentamente executados como foi o caso da morte da prostituta Raquel Nascimento, que foi degolada, e de seu agenciador José Naciel, morto a facadas, em abril de 2013, na Asa Norte ${ }^{130}$, contribuem ainda mais para esse sentimento de insegurança e incerteza moral. Não foi ao acaso que, logo depois desse crime bárbaro, a polícia militar deflagrou a "Operação Puritaten" (Operação Pureza, em latim), uma ação claramente voltada para reduzir a prostituição de rua na Asa Norte. ${ }^{131}$

Outro fator que deve ser trazido à discussão é a questão da subnotificação dos crimes, conhecida também como "cifra negra" (HULSMAN, 1997, p.65). Não se pode reduzir todo universo de crimes relacionados à atividade de prostituição que aconteceram na avenida W3 norte, no período objeto da pesquisa, a apenas 121 registros, pois, por uma série de fatores, em um número significativo de casos, vítimas e testemunhas não buscam a delegacia de polícia para registrá-los, ora por medo, ora por excesso de afazeres diários ou mesmo por falta de crença no sistema de justiça.

Inclusive, em entrevista com a delegada-chefe da DEAM da PCDF, Ana Cristina Santiago, me disse que as prostitutas não buscam muito a DEAM para relatar agressões que sofrem no trabalho, embora ela acredite que elas sejam submetidas a vários tipos de violência durante a execução dos programas. Ela levantou duas hipóteses, que foram confirmadas

\footnotetext{
129 “Assistiríamos hoje a um processo de crescente individualização, em que as estruturas de pensamento e de integração social típicas da modernidade (e.g., estratificação por classes, família nuclear, papéis de gênero) estariam progressivamente a dissolver-se. Este processo teria, a par de uma faceta libertadora (e.g., emergência de identidade de gênero alternativas, de novas configurações familiares), um efeito desestabilizador, na medida em que implicaria a perda da segurança em relação às normas que devem orientar a nossa conduta social. Desta forma, a atual relativização dos valores teria lançado boa parte das pessoas num estado de incerteza moral 'ontologicamente desconcertante"' (MACHADO, 2004, p. 94).

${ }_{130} \mathrm{http}: / / \mathrm{g} 1 . \mathrm{globo} . c 0 \mathrm{~m} /$ distrito-federal/noticia/2013/04/casal-e-encontrado-morto-em-apartamento-em-brasilia.html Acesso em 26/9/2016.

${ }^{131}$ Nessa operação, cinco pousadas localizadas nas quadras 703, 704, 705, 707 e 711 norte foram fechadas por falta de alvará de funcionamento, e por sabidamente serem utilizadas para a prática de programas pelas prostitutas. Uma delas usava uma lan house como fachada para despistar a fiscalização, e, segundo a Polícia Militar, "tinha toda uma estrutura, como frigobar, atendimento de quarto, e funcionava aí como local de prostituição e também uso e tráfico de drogas." ${ }^{131}$ É como se no dia-adia fosse esquecido que constitui crime manter casa de prostituição, como discutido na introdução do presente trabalho, e somente diante de um crime brutal, como a morte de Raquel e seu cafetão José Naciel, a máquina de repressão dessa atividade despertasse. "O assassinato da garota de programa Raquel Nascimento, 26 anos, em uma quitinete da comercial da 210 Norte, deixou em alerta as equipes de segurança e de fiscalização do Distrito Federal. Doze dias após o homicídio, a Polícia Militar, com o apoio da Agência de Fiscalização do DF (Agefis), deflagrou uma ação para interditar pousadas irregulares em funcionamento na Asa Norte. Os estabelecimentos são alvo constante de reclamações de vizinhos, sob a alegação de que favorecem a prostituição e o tráfico de drogas. Ao longo da semana, o Correio percorreu diversas quadras comerciais da Asa Norte e flagrou, além de hospedarias ilegais, salas comerciais alugadas para moradia e sem alvará de funcionamento."

http://www.correiobraziliense.com.br/app/noticia/cidades/2013/05/04/interna_cidadesdf,364254/pousadas-interditadas-naasa-norte-serviam-para-a-prostituicao.shtml Acesso em 26/09/2016.
} 
posteriormente com a entrevista dos agentes de polícia da PCDF, responsáveis pelo registro das ocorrências policiais na Asa Norte, e também pela minha própria experiência, como delegada de polícia plantonista na Asa Norte. A primeira hipótese seria que as prostitutas não buscam muito a polícia para relatar agressões, pois temem expor seus clientes e assim serem indicadas como profissionais não confiáveis e, por isso, perder futuros clientes. A segunda hipótese, segundo apontou Ana Cristina, refere-se ao fato de que as prostitutas de rua têm personalidade forte, são articuladas e são capazes de se autodefenderem, de forma que, em situações de agressões verbais ou até físicas leves, elas conseguem de imediato resolver o conflito sem precisar de ajuda de terceiros ou do Estado.

Em entrevista com um agente de polícia responsável pelo registro de ocorrências na $2^{\mathrm{a}}$ DP, pude perceber outra hipótese para essa subnotificação, ou não procura das prostitutas às delegacias para relatar esses abusos que elas possam sofrer: o valor de sua palavra. Esse agente me contou um caso em que ele confessou que se sentiu desconfortável ao registrar um estupro noticiado por uma prostituta, por duvidar de sua versão, mas mesmo assim ele efetuou o boletim de ocorrência. Contudo, ele mesmo reviu e refletiu sobre sua postura, semanas depois, quando soube que várias outras prostitutas foram vítimas do mesmo homem apontado pela prostituta no seu registro e que ele foi, finalmente, preso pela Polícia Civil em trabalho investigativo em uma cidade-satélite.

Observamos que dos 74 registros no grupo de crimes violentos, em 44 deles os profissionais do sexo (prostitutas e travestis) figuram como vítimas, em 12 como testemunhas e em 24 como autores, isso, ao longo de 05 anos. Pode-se supor que haja grande subnotificação dos crimes, diante de uma média de 8,8 crimes violentos por ano contra esses profissionais do sexo.

Tabela 2. Relação entre o tipo de crime e a participação da prostituta

\begin{tabular}{|c|l|c|c|c|}
\hline Grupos & \multicolumn{1}{|c|}{ Crime } & Vítima & Testemunha & Autora \\
\hline \multirow{4}{*}{$\begin{array}{c}\text { Crimes } \\
\text { violentos }\end{array}$} & Ameaça & 17 & 4 & 13 \\
\cline { 2 - 5 } & Busca de cadáver & 0 & 1 & 0 \\
\cline { 2 - 5 } & Estupro & 4 & 0 & 0 \\
\cline { 2 - 5 } & Extorsão & 1 & 0 & 0 \\
\cline { 2 - 5 } & Incêndio & 0 & 0 & 1 \\
\cline { 2 - 5 } & Homicídio consumado & 1 & 1 & 0 \\
\cline { 2 - 5 } & Homicídio tentado & 3 & 1 & 1 \\
\hline
\end{tabular}




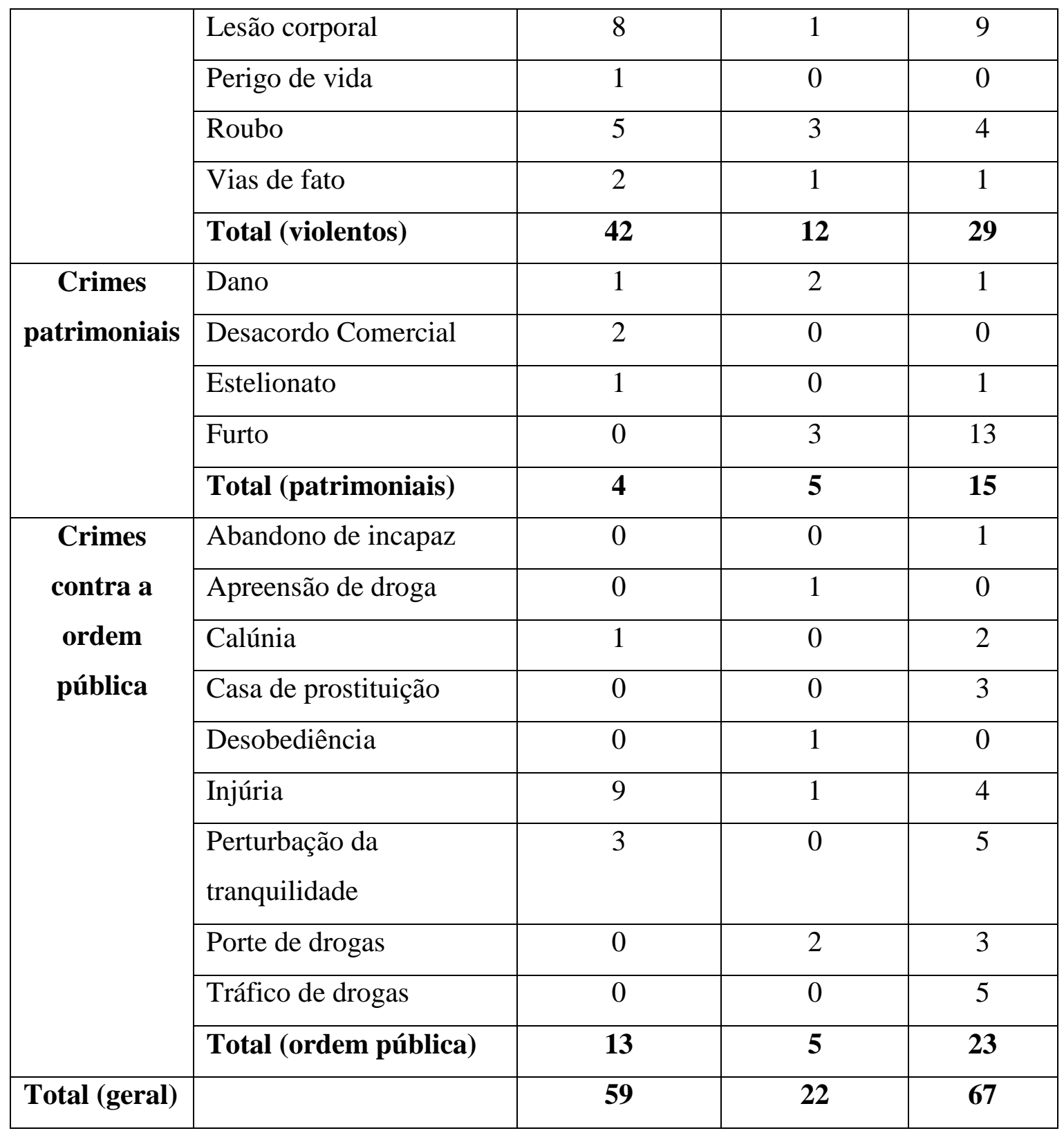

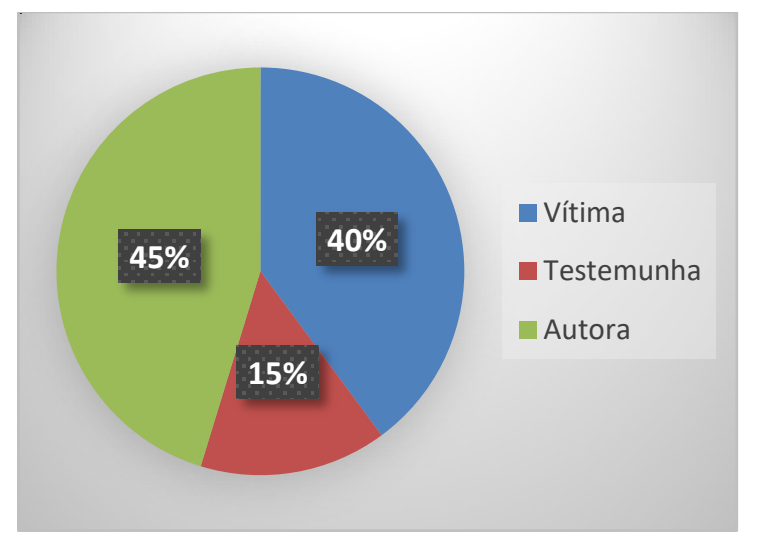

Gráfico 2. Tipos de participação das prostitutas em crimes 


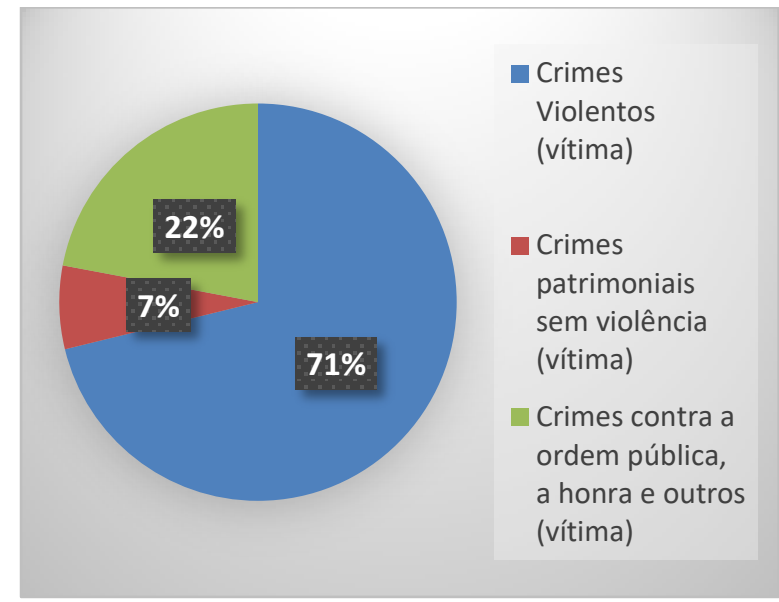

Gráfico 3. Prostituta como vítima por tipo de crime

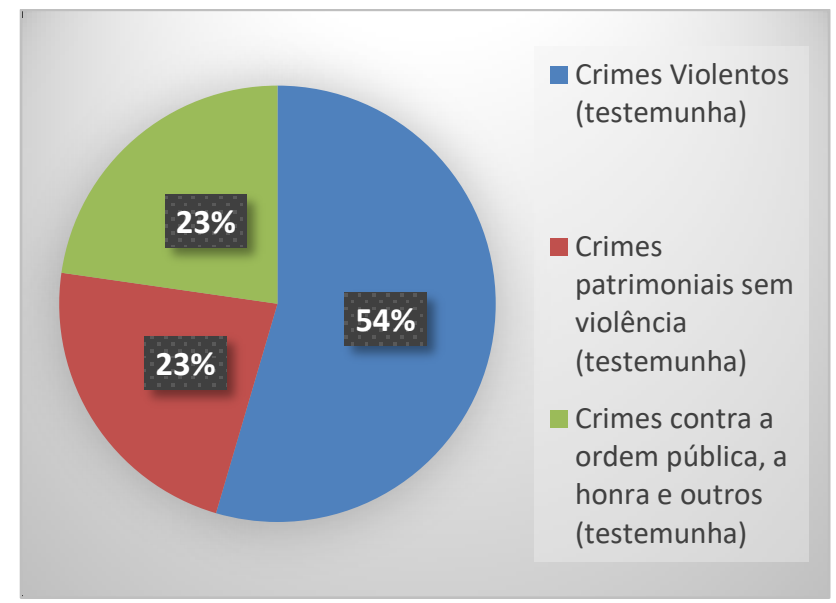

Gráfico 4. Prostituta como testemunha por tipo de crime

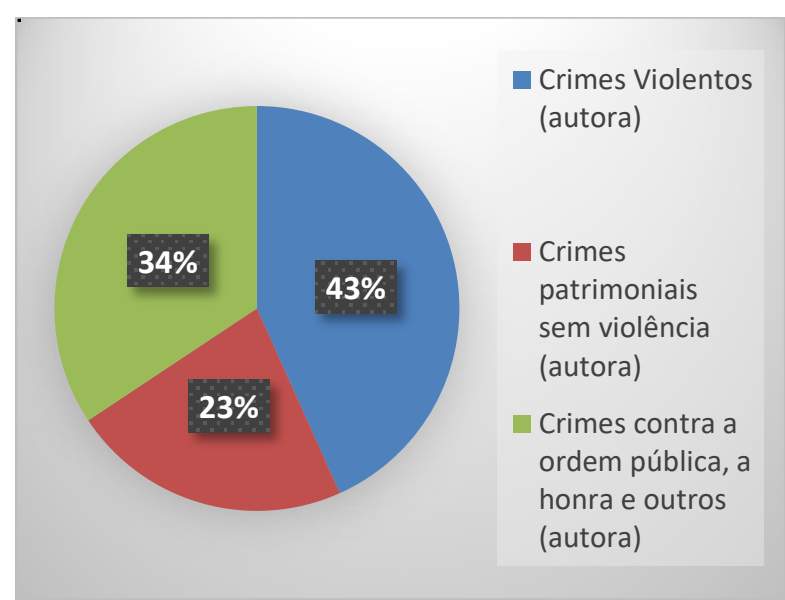

Gráfico 5. Prostituta como autora por tipo de crime 


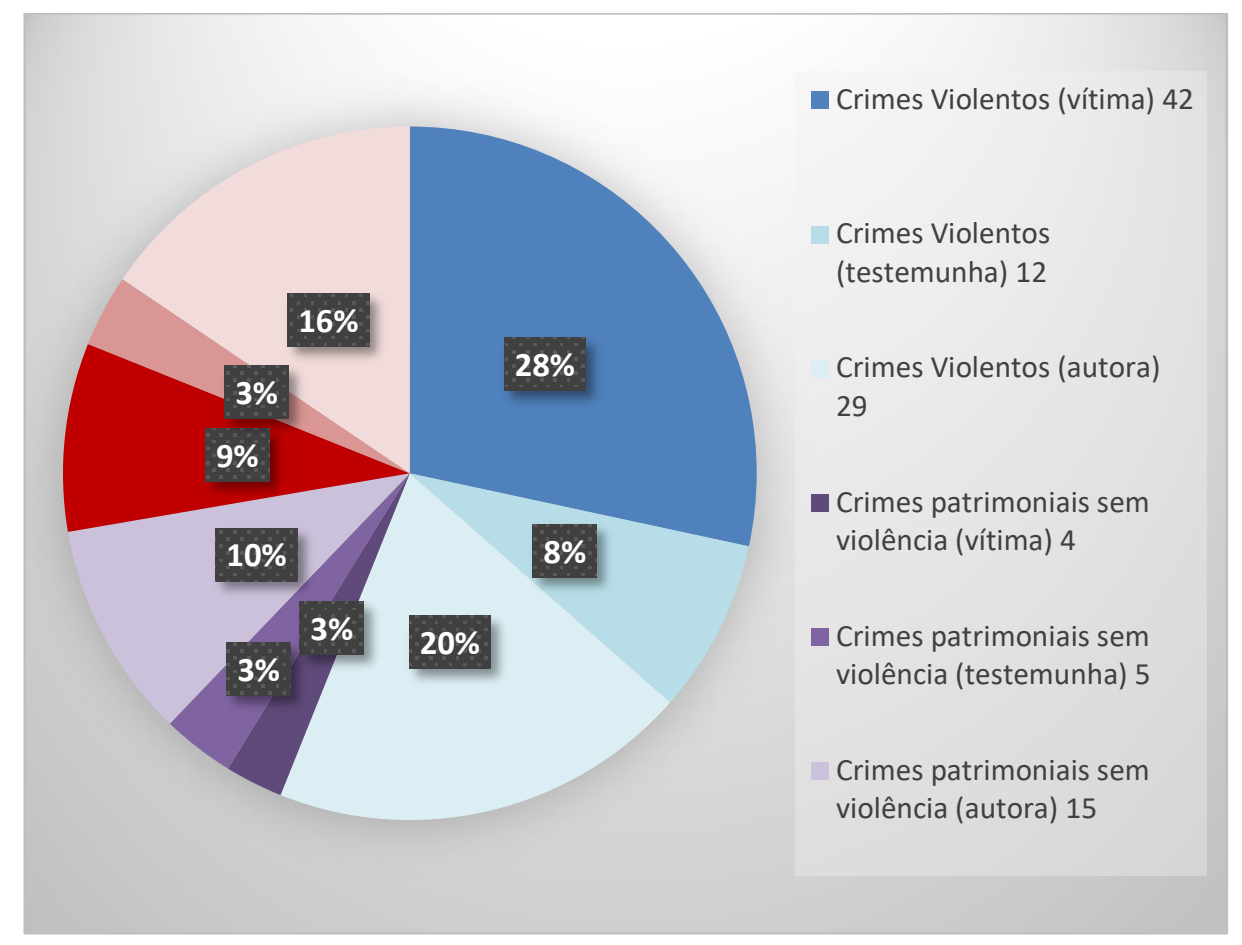

Gráfico 6. Relação entre o tipo de crime e a participação da prostituta

Nesse sentido, em entrevista com agentes de polícia do balcão das delegacias da Asa Norte sobre o que levaria, na opinião deles, as prostitutas às delegacias, eles responderam que o motivo principal era o "desacordo comercial", que, na categoria nativa, significa que elas buscam a polícia para fazer com que o cliente pague o preço acertado com elas pelo programa. Alguns deles disseram que as prostitutas confiam na polícia para garantir o pagamento de seu programa, pois, apesar de a conduta não ser crime e sim uma quebra contratual, regida pelo Direito Civil, os policiais as ajudam porque não querem que o conflito se intensifique e chegue à esfera penal. Assim, ainda segundo os agentes, os clientes, constrangidos na delegacia, acabam efetuando o pagamento combinado. Eles também me disseram que, muitas vezes, por vontade dos envolvidos, não há sequer registro de qualquer boletim de ocorrência, uma vez que o conflito foi resolvido.

Por outro lado, e ainda sobre conflitos durante o pagamento do programa, os agentes de polícia também disseram ser bastante comum a ida de clientes até a delegacia para registrarem "furtos", nos quais, o profissional do sexo (normalmente, prostituta ou travesti) teria subtraído pertences pessoais deles, na maioria das vezes celulares. Contudo, aprofundando a conversa com esses comunicantes/clientes, eles verificam que, na verdade, houvera um desentendimento em relação ao preço do programa, um "desacordo comercial" e que a prostituta então teria subtraído o objeto como pagamento pelo programa, o que desclassificaria o crime de furto para o crime de exercício arbitrário das próprias razões, que 
consubstancia o adágio popular de "fazer justiça com as próprias mãos". Assim, há várias ocorrências policiais registradas como furto, que, na verdade, são exercício arbitrário das próprias razões.

A partir da perspectiva trazida pelos entrevistados, parece que, como a sua atividade não é regulamentada e não há alternativas legais, junto à Justiça Cível para cobrar o pagamento pelos seus serviços, as prostitutas se veem compelidas a "fazer a justiça com as próprias mãos”. Afinal, ainda de acordo com os entrevistados, não são todas as prostitutas que estão dispostas a levar o cliente até uma delegacia de polícia ou simplesmente acionar a polícia militar para constrangê-lo a efetuar o pagamento, pois tal conduta significa ser considerada no mercado do sexo como a prostituta que não garante discrição e que expõe os clientes.

Contudo, uma recente e paradigmática decisão aponta para uma maior proteção jurídica à prostituição. Prolatada pela $6^{\text {a }}$ Turma do Superior Tribunal de Justiça, em 17 de maio de 2016, nos autos do Habeas Corpus 211.888-TO, ela desclassificou a conduta de "arrancar um cordão com pingente folheado de cliente diante do não pagamento do programa de roubo para exercício arbitrário das próprias razões. Em suas razões de decidir, o Ministro Rogério Schietti Cruz fundamentou que

Sob a perspectiva de que a história dos crimes sexuais é, em última análise, a história da secularização dos costumes e práticas sexuais, não é possível negar proteção jurídica àqueles que oferecem seus serviços de natureza sexual em troca de remuneração, sempre com a ressalva, evidentemente, de que essa troca de interesses não envolva incapazes, menores de 18 anos e pessoas de algum modo vulneráveis, desde que o ato sexual seja decorrente de livre disposição da vontade dos participantes e não implique violência (não consentida) ou grave ameaça. Acenando nessa direção, oportuna é a transcrição do seguinte excerto doutrinário: "Na órbita do Direito Civil, a prostituição deve ser reconhecida como um negócio como outro qualquer (...) O comércio sexual entre adultos envolve agentes capazes. Como já se deixou claro, reconhecida a atividade no rol das profissões do Ministério do Trabalho, o objeto é perfeitamente lícito, pois é um contato sexual, mediante remuneração, entre agentes capazes. Seria o equivalente a um contrato de massagem, mediante remuneração, embora sem sexo. Não há forma prescrita em lei para tal negócio, que pode ser verbal." Aliás, de acordo com o Código Brasileiro de Ocupações, de 2002, regulamentado pela Portaria do Ministério do Trabalho n. 397, de 9 de outubro de 2002, os profissionais do sexo são expressamente mencionados no item 5198 como uma categoria de profissionais, o que, conquanto ainda dependa de regulamentação quanto a direitos que eventualmente essas pessoas possam exercer, evidencia o reconhecimento, pelo Estado brasileiro, de que a atividade relacionada ao comércio sexual do próprio corpo não é ilícita e que, portanto, é 
passível de proteção jurídica. Dessas considerações - que, por óbvio, não implicam apologia ao comércio sexual do próprio corpo, mas apenas o reconhecimento, com seus naturais consectários legais, da secularização dos costumes sexuais e a separação, inerente à própria concepção do Direito Penal pós-iluminista, entre Moral e Direito - pode-se concluir, como o faz doutrina, ser perfeitamente viável que o trabalhador sexual, não tendo recebido pelos serviços sexuais combinados com o cliente, possa se valer da Justiça para exigir o pagamento. ${ }^{132}$

Ao reconhecer a necessidade da separação entre Direito Penal e moral, a decisão acima transcrita apresenta-se como um novo capítulo na narrativa jurídico-moral acerca da atividade de prostituição, cujas primeiras fases foram rapidamente descritas no capítulo introdutório do presente trabalho. Esse tema será melhor abordado no último capítulo dessa dissertação.

Dito isso, é importante lembrar-se da distinção entre elementos ditos, não ditos e interditos, apontados por Foucault como centrais para a elaboração do dispositivo. Com a análise das 121 ocorrências policiais em questão, pude observar que os termos "cafetão" e "cafetina" foram quase inexistentes nos históricos dos registros. Aliás, não poderia ser diferente, pois essas figuras que orbitam em torno da atividade de prostituição operam numa fronteira tênue em relação ao crime de favorecimento à prostituição. De toda amostra, houve incidência de apenas 3 ocorrências dos termos "cafetão" e "cafetina".

Considerando que, geralmente os comunicantes das ocorrências policiais ou são as próprias prostitutas, ou os clientes, ou mesmo os moradores da região, incomodados com a atividade, dificilmente a figura do cafetão aparece nas notícias de fato trazidas espontaneamente até a polícia.

Contudo, em algumas ocorrências, era possível notar alguns lampejos da sua existência, como no caso em que outra prostituta ou amiga ia até a delegacia na condição de testemunha para apoiar a vítima em algum caso específico. Como visto no capítulo anterior, durante minhas observações realizadas na avenida W3 norte, algumas vezes, pude notar a presença do agenciador da prostituição, caminhando pela avenida, conversando com as garotas de programa, com um caderno e uma prancheta nas mãos, de possível contabilidade da atividade. Tanto nos registros das ocorrências policiais quando nas ruas, essa figura do cafetão permanece não dita e, por vezes, interdita. Todavia, nos próximos capítulos, ela reaparecerá nas narrativas das prostitutas e também dos clientes, dos policiais militares e civis, e também de outros profissionais envolvidos com a atividade de prostituição.

\footnotetext{
132 Íntegra da decisão em: https://ww2.stj.jus.br/processo/pesquisa/?src=1.1.2\&aplicacao=processos.ea\&tipoPesquisa=tipoPesquisaGenerica\&num_regi stro=201101529522 Acesso em 26/9/2016.
} 
Quanto à utilização dos termos "garota de programa" e "prostituta" para o praticante da prostituição, houve uma diferença de 55 incidências para o primeiro e 24 para o segundo, nos 121 registros. Inicialmente, imaginei que se tratava de uma preferência dos agentes de polícia por um termo mais neutro, já que a palavra "prostituta" teria uma carga de representação social negativa, como já visto anteriormente. Contudo, nas entrevistas com os agentes de polícia, questionados sobre a escolha entre esses termos, todos disseram ser indiferentes, e que eles, na verdade, registram o termo utilizado pela profissional do sexo para se apresentar como tal, pois eles entendem que causam menos constrangimento ao respeitar a forma como essas profissionais se auto identificam. Por outro lado, mostra-se relevante o fato de elas espontaneamente optarem por um termo mais neutro, ao descrever a sua atividade para os policiais.

Quanto à apropriação do espaço pela atividade de prostituição é possível, com a análise dos presentes registros, inferir uma segregação espacial das prostitutas, no sentido de haver uma migração da prostituição entre as quadras finais da avenida W3 norte, onde havia uma concentração histórica, já analisada no Capítulo 1, para as demais quadras ao longo da avenida. Nesse ponto, convém lembrar o forte movimento dos moradores da quadra 713, que estamparam sua indignação com a prostituição na faixa noticiada no início desse capítulo, o que repercute nos registros de ocorrência, já que dos 08 registros de perturbação de sossego ou tranquilidade da amostra, nos 05 anos que foram objeto de investigação, 06 partiram de moradores das quadras finais $(713,316,715,712,716$ e 912 norte). Interessante que esses registros confirmaram minhas observações do espaço sobre a concentração das prostitutas ao longo de quase toda W3 norte, também verificada na pesquisa de Gustavo Capela (2003).

Em relação a uma comum representação social entre a prostituição e os crimes relacionados a drogas, na amostra, dos 121 registros, houve sete deles relacionados com entorpecentes, 4 tráficos, todos eles apresentando prostitutas como autoras, e 5 portes de drogas para consumo próprio, dos quais em 3 as prostitutas eram autoras e em 2 casos apenas testemunhas. O envolvimento de prostitutas com o tráfico de entorpecentes foi objeto de questionamento aos agentes de polícia responsáveis pelos registros das ocorrências e, segundo suas representações sobre o tema, eles narraram que, na grande maioria dos casos, as prostitutas não são as principais traficantes, ou seja, os entorpecentes não pertencem a elas, mas são apenas responsáveis por repassá-los, a pedido do principal traficante, a seus clientes que, quando vêm à procura de serviços sexuais, costumam também comprar drogas. Aliás, em uma entrevista com um policial civil, ele relatou um caso em que a pessoa se apresentava como prostituta, inclusive permanecia "na pista", mas essa atividade constituía mera 
camuflagem para a sua atividade principal: o tráfico ilícito de entorpecentes, sendo que ela já fora inclusive condenada por este crime. Naturalmente, apenas com minhas observações do espaço, não pude presenciar negociações de venda de entorpecentes, mesmo porque, segundo conversas com clientes e também com prostitutas, o consumo se dá, quando ocorre, em um lugar reservado, durante a execução do programa. Assim como acontece com a prostituição, a discrição é um importante componente também para o empreendimento de tráfico ilícito de entorpecentes, como também percebido e mencionado por CAPELA (2013, p. 132).

Todavia, apesar dessas percepções não terem sido refletidas significativamente nas ocorrências policiais no período analisado (01/01/2010 a 31/12/2015), os moradores da Asa Norte se mostram bastante incomodados com essa associação do tráfico com a atividade de prostituição. Em reportagem do Jornal de Brasília, de 24/05/2016, há um depoimento claro dessas preocupações dos moradores do local:

Meu filho já sabe o que é crack, cocaína e prostituição. Aprendeu da pior maneira possível, da janela de casa, em pleno centro de Brasília”. O depoimento emocionado é de um morador da 704/705 Norte. Assim como ele, quem vive ali tem um único desejo: acabar com a compra e venda de drogas na quadra. Segundo a comunidade, o problema é antigo e está em ascensão. A parceria entre o tráfico e a prostituição se fortaleceu e agravou o cenário. Desde então, os moradores não têm mais sossego. Tudo começa cedo, assim que a banca de jornal fecha, por volta das $18 \mathrm{~h}$. A ação acontece na frente de todos, sem a menor preocupação. Mais tarde, às $21 \mathrm{~h}$, a droga começa a circular e vai até de manhã. Uma pousada de fachada ajuda a dar cobertura. (...) "Eles são espertos. Andam com pouca quantidade. O resto, escondem nas árvores, nos pneus dos carros, no telhado da banca e nos bueiros. Uma vez, eles arrombaram a porta da minha loja. Tinham amarrado as trouxinhas no bueiro, mas elas caíram. Tiveram de destruir meu comércio para pegá-las”, conta um comerciante. (...) "Tive que passar fita adesiva nas calotas para tentar inibir. Também tive meu carro arranhado e peças, quebradas”, diz outro morador. (...) Ele relata que já foi ameaçado e que não é fácil criar os filhos naquele ambiente. "A madrugada inteira, a gente escuta todo o tipo de barulho. Briga entre prostituta é o que mais tem. Ao olhar pela janela, um dos traficantes me viu e disse: 'Aqui quem manda sou eu. Eu não tenho mais nada a perder. Tudo o que eu tinha nessa vida eu já perdi”, lembra. (...) Há relatos de que as garotas de programa escondem drogas e também as vendem em troca de comissão. "Elas já negociam o programa e os entorpecentes. Às vezes, somente vendem. É mais fácil para elas fazerem isso. De longe, parecem negociar apenas o programa. A 
polícia não tem como impedir", relata um morador. (Jornal de Brasília, de 24/05/2016). ${ }^{133}$

Nas minhas observações das quadras 703/704, de fato, percebi a presença de mais pousadas, onde são realizados os programas das prostitutas e também uma maior circulação de veículos na região, talvez não apenas em busca de serviços sexuais, mas também da compra de entorpecentes. Assim, percebi mais manchas da prostituição nessas quadras 703/704, de forma mais intensa, e algumas nas quadras 707/708, não havendo quase qualquer profissional do sexo nas quadras finais da avenida W3 norte. Quanto às quadras 714/715 norte, tradicional ponto de prostituição em Brasília, vi apenas uma ou duas prostituas no local, observações que se harmonizam no tempo em relação aos registros das ocorrências policiais.

Ressalta-se, porém, que a construção de todas essas inferências sobre a relação entre a prostituição e a criminalidade na avenida W3 norte a partir dos registros das ocorrências policiais constitui a razão de ser da utilização aqui do método da análise de conteúdo. (FRANCO, 2008, p. 29). Afinal, segundo esse método, os documentos que constituem os “dados estatísticos" nada mais são que resultados, também, de representações sociais pelos seus autores.

Assim, novamente, não estamos diante da verdade, mas sim de versões. Nesse contexto, o enfoque das relações acima trabalhadas foi na tentativa de elaboração de um dispositivo entre a prostituição e a criminalidade na avenida W3. Se o objetivo então é o dispositivo, vamos a ele.

\section{Notas para um dispositivo de prostituição, cidade e criminalidade na W3 norte}

Novamente, ao final da seção, acrescentarei mais notas ao dispositivo de prostituição na avenida W3 norte, agora com algumas reflexões sobre os "dados" da criminalidade relacionada à atividade de prostituição no período de 01/01/2010 a 31/12/2015 no local.

Pelas notícias de jornal apresentadas ${ }^{134}$, vimos que há, uma quase que automática associação entre a criminalidade e a atividade de prostituição pelos moradores das proximidades da avenida W3 norte. Ademais, observamos também que o crime e a prostituição guardam uma relação de semelhança, pois ambos são considerados desvios a

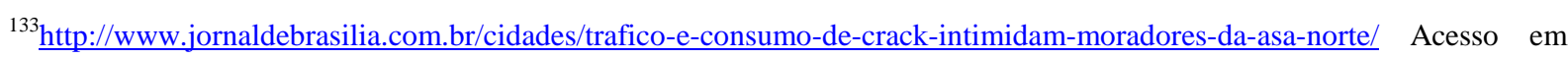
27/09/2016.

${ }^{134}$ Aliás, a própria narrativa midiática em si apresenta características peculiares sobre o fato jornalístico, que realçam a novidade, o sensacionalismo, tabus e preconceitos sociais, em geral. Não seria diferente o tratamento dado ao assunto prostituição, que reforça representações sociais morais, religiosas, jurídicas, médicas sobre a prostituição a fim de constituir um mecanismo de comunicação direta com o leitor que já as traz consigo.
} 
padrões de condutas sociais, que, no caso do primeiro, é a lei, e no segundo, o dispositivo de sexualidade (FOUCAULT, 1998, p. 100). Nesse contexto, ansiedades e angústias “decorrentes de problemas sociais mais profundos, irresolúveis ou ameaçadores para o status quo, são, portanto, canalizadas e focalizadas na figura do crime de rua e do criminoso" (MACHADO, 2004, p. 90) e, no nosso caso, na figura das prostitutas, que "amanhã nos expulsam de nossas casas e usam nossas camas" (Jornal de Brasília, 20/4/2012), que passam a simbolizar esses problemas. Ou seja, em grande medida, funcionam como "bodes expiatórios" ou mesmo metonímias, pois objetivam problemas mais complexos e de difícil apreensão, ao contrário da ideia de prostituta e de criminoso que possuem maior visibilidade e são externos à subjetividade da pessoa. Assim, a culpa do problema passa a ser do outro, da "puta" e do "bandido", e não das minhas incertezas, ansiedades e frustrações.

Nesse contexto, o crime e a afronta ao dispositivo de sexualidade funcionam como canalizadores da ansiedade e do medo urbano generalizado, o que traz, no caso da prostituição, um “interdito criminalizador" em relação a todas as atividades que orbitam em torno dela - como visto no capítulo introdutório, o local onde é feita a atividade de prostituição com habitualidade é objeto do crime de casa de prostituição, a conduta do agenciador ou o auxiliar da prostituta, mesmo em que haja repartição adequada de lucros, pode ser objeto do crime de favorecimento à prostituição. Como se houvesse um "toque de leprosa" da prostituta, pois tudo que ela "toca" ou que a rodeia é associado à ideia de crime ou de sujeira e doença, como, aliás, acontece desde a Idade Média.

Inclusive, diante disso, até a forma de apropriação do espaço pela prostituição na avenida W3 norte, na utilização do fluxo dos carros nos estacionamentos nas quadras comerciais, o que chamo de "trottoir drive-thru", no capítulo anterior, tem seus revezes e acaba também por constituir um círculo vicioso que orbita em torno da prostituição e de seu "toque de Midas invertido". Conforme inferido nas análises das ocorrências e também nas representações sociais dos moradores, a mesma facilidade e comodidade em que a disposição das prostitutas nos estacionamentos da W3 norte oferece aos clientes como vitrine do sexo, também garante a furtividade e rapidez para a comercialização de drogas. Mais drogas, mais criminalidade, mais "presença incômoda", mais polícia, mais abordagens policiais, menos clientes... e hora de mudar de ponto e de estratégias para a prostituição "autêntica", ou seja, aquela que não é utilizada como camuflagem à prática de crimes.

Essa associação, ao menos no imaginário social, entre prostituição e criminalidade reforça a segregação moral e espacial da prostituta, e restringe o seu acesso a direitos básicos, como o do trabalho. 
Nesse sentido, decorrente também dessa ausência de reconhecimento ao direito ao trabalho, verificamos que as prostitutas buscam a polícia, muitas vezes, para garantir o pagamento de seus serviços, em caso de recusa por parte do cliente. Afinal, como seria executar nos Juizados Especiais um contrato de prestação de serviços sexuais? Assim, as ocorrências policiais registradas como furto ou roubo de pertences de clientes consistiam, muitas vezes, em exercício arbitrário das próprias razões, em "fazer justiça com as próprias mãos". Ora, quem não pode contar com o acesso à Justiça formal, restar-lhe-ia o desenvolvimento de estratégias próprias ou "a sua própria Justiça".

Finalmente, outro fato digno de nota para a elaboração do nosso dispositivo é o não dito das subnotificações de crimes que retratam a violência a que estão submetidas as prostitutas em sua atividade profissional. Tal subnotificação pode ser explicada, em parte, pela forma como o Sistema de Justiça enxerga a prostituta, que está estampada, por exemplo, na utilização da expressão "prostituta das provas", a qual faz referência à desconfiança que se deve ter em relação à prova testemunhal.

Além disso, outro motivo para essa subnotificação estaria nas circunstâncias a que estão submetidos os crimes nos quais a prostituta é vítima, pois eles normalmente ocorrem distantes dos olhos do público, em ambientes fechados onde os programas são feitos. Assim, regra geral, nesses crimes, a prova testemunhal é a única disponível, e se a própria prova testemunhal já é desvalorizada pela narrativa jurídica ao ser considerada "a prostituta das provas", imagine como a palavra de uma prostituta seria ou é tratada nos sistemas de representações sociais de Justiça? ${ }^{135}$ Nesse contexto, não compensaria, para a prostituta, enfrentar essa desconfiança institucional e a exposição de narrar, a terceiros, fatos violentos, que para elas estão internalizados como "risco da atividade" de prostituição. Daí a sua postura de mulheres fortes e determinadas, relatadas também pelos policiais responsáveis pelos registros das ocorrências.

Mas essas são apenas inferências, versões decorrentes de "dados" sobre criminalidade e observações do espaço da W3 norte. Resta agora dar vozes a elas, as prostitutas. É o que veremos no próximo capítulo: o verso da verdade delas.

\footnotetext{
135 Basta lembrar que, como vimos no capítulo introdutório, não faz tanto tempo se considerava que o testemunho da prostituta não tinha valor probatório em processos cíveis.
} 


\section{Capítulo 3. "Luz na passarela que lá vem elas" - As prostitutas da W3 norte}

\section{Vencendo moinhos - percursos metodológicos de entrevista com as prostitutas da W3 norte}

Para alcançar o objeto principal dessa pesquisa, que é a construção de um dispositivo ${ }^{136}$ para a prostituição na W3 norte, não há dúvidas de que é imprescindível dar voz e luz às protagonistas da atividade de prostituição. Afinal, como construir esse dispositivo ou entender a dinâmica da atividade de prostituição sem considerar a versão das próprias prostitutas? Assim foi preciso ir ao campo e falar com elas.

Confesso que a atividade de "abrir as cortinas" desse cenário, que é o "campo", dá calafrios, por nunca se saber ao certo por onde e como começar. Contudo, confortei-me ao verificar que pesquisadoras bem mais experientes, como Soraya Simões, que estudou a prostituição carioca na Vila Mimosa, descrevem essa falsa expectativa de encontrar a "entrada certa" como "um sonho quixotesco" (SIMÕES, 2010).

Moinhos de ventos ou não, o campo, no caso aqui, a avenida W3 norte, teve que ser explorada. E, mesmo com a ajuda de outras pesquisas e etnografias ${ }^{137}$, tive que desenvolver as minhas próprias estratégias, usando o velho mecanismo científico da tentativa e erro, aprendendo muito tanto com os "nãos" como com os "sims" que recebi. Definitivamente não há entrada certa e tive muitas dúvidas para entrevistar as garotas de programa. Como ir? Que horas ir? Vou sozinha? Que roupa vestir? Devo ser percebida? Levo gravador? Levo caderninho de anotações? Como me identificar? O que devo observar? Como observar? Como devo me portar?

Como guia metodológico, utilizei os parâmetros da entrevista reflexiva, a qual traz o ato da entrevista para uma arena de conflitos e contradições, "considerando os critérios de representatividade da fala e a questão da interação social que está em jogo na interação do pesquisador/pesquisado" (SZYMANSKI, 2011, p. 11). Esse percurso metodológico escolhido está em harmonia tanto com a ideia da construção de um dispositivo de prostituição, ao considerar o entrelaçamento de vários elementos heterogêneos para entender o fenômeno,

\footnotetext{
${ }^{136}$ Já tratei do conceito de dispositivo na parte da Introdução. Contudo, rememoro aqui o conceito dado pelo próprio Foucault sobre sua metodologia: "isso que eu tento identificar sob este nome (isto é, dispositivo) é (...) primeiramente, um conjunto de elementos heterogêneos, composto por discursos, por instituições, por arranjos de arquitetura, por decisões regulamentares, por leis, por medidas administrativas, por enunciados científicos, por proposições filosóficas, morais, filantrópicas, enfim: daquilo que é dito bem como do que não é dito, são os elementos do dispositivo. O dispositivo, por si só, é o resultado que se pode estabelecer entre estes elementos.” (apud SVERRE Raffnsøe, 2008,p. 58). (tradução livre)

${ }^{137}$ (SIMÕES, 2010); (CARUSO, 2009); (CAPELA, 2013); (TEIXEIRA, 2003).
} 
como também com o método da pesquisa das representações sociais. Isso porque, nas conversas preliminares, já percebi, de imediato, que havia muitas informações nos gestos das entrevistadas, nos olhares, nos ditos, não ditos e interditos, que elas traziam à tona, a depender do dia, do seu humor e também das minhas intervenções durante a entrevista.

Nesse sentido, o método da entrevista reflexiva, que "considera como conteúdos fatos, opiniões sobre fatos, sentimentos, planos de ação, condutas atuais ou passados, motivos conscientes para opiniões e sentimentos" (SZYMANSKI, 2011, p. 10), mostrou-se de extrema relevância para que eu pudesse atentar também para a história de vida das entrevistadas e suas perspectivas para o futuro. Além disso, esse método também leva em conta que a entrevista, ou seja, o momento de se expressar, significa um ato de respeito ao entrevistado, uma reflexividade horizontal, na qual o entrevistado também tem expectativas acerca do entrevistador. Assim, procurei sempre ter uma postura aberta de forma a responder a todas as perguntas que as entrevistadas faziam sobre minha vida (principalmente sobre minhas atividades acadêmicas), já que estávamos em situação de interação, apesar de que esses momentos foram poucos.

Finalmente, com essa perspectiva da entrevista reflexiva, percebi que o momento das entrevistas constituiu, muitas vezes, tanto para as entrevistadas como para mim também, um ato "de organização das ideias e de construção de um discurso para o interlocutor" (SZYMANSKI, 2011, p.14). Vários temas, que antes eram abstratos ou estavam em nossos pensamentos de forma desorganizada ou mesmo desapercebidos, tornaram-se concretos, por meio da construção de uma narrativa ou mesmo da percepção intelectiva de atos corriqueiros, que até então nunca tinham sido objeto de reflexão nem pelas entrevistadas e nem por mim. Realmente, como disse Szymanski, percebi "um processo interativo complexo, de caráter reflexivo, num intercâmbio contínuo entre os significados e o sistema de crenças e valores perpassados pelas emoções e sentimentos dos protagonistas" (2011, p. 14).

Conteúdos verdadeiros? Não sei. Mas não é essa a questão com que me preocupo aqui. Quem pode dizer o que é a verdade, sendo que cada um tem seu próprio conjunto de representações sociais, sua própria versão sobre elas? Não existem verdades em si. Existem versões. E as que eu vou apresentar agora, posso dizer que são resultados de um processo interativo das versões das entrevistadas e também da minha versão, estampada, no caso, por meio dos meus questionamentos a elas.

Fui ao campo em dois períodos. Primeiro, entre os meses de junho e agosto de 2015; e, depois, entre os meses de maio e setembro de 2016. Para conversar com as prostitutas, eu sempre ia à noite, entre $19 \mathrm{~h} 30$ até $00 \mathrm{~h} 30$, e, poucas vezes, fui pela madrugada, porque não 
havia muitas nas ruas e as que havia, naquele momento da noite, não se apresentavam muito abertas para entrevistas. Apesar de ter conversado com várias, fiz relatos de apenas 10 entrevistadas, por suas falas serem as mais relevantes, e cujos nomes são fictícios. Como o anonimato é, de fato, uma questão chave para a prostituição na avenida W3 norte, a utilização do gravador era impossível, pois nenhuma entrevistada o aceitou, além de não deixar as prostitutas à vontade para livre expressão. O caderno de anotações na "pista"138 também não se mostrou uma boa alternativa. Então, tive que desenvolver a seguinte estratégia: logo após cada entrevista, eu me distanciava, ia até o carro e gravava as informações e impressões obtidas. Depois eu as transcrevia no diário de campo.

Uma situação inusitada, bastante comum entre as entrevistadas, era quando eu me apresentava como estudante do mestrado em Sociologia da Universidade de Brasília, e elas diziam que havia vários homens que se diziam também pesquisadores que as abordavam para conversar e tentar um programa gratuito. Às vezes, ríamos juntas e então eu mostrava minha carteirinha de estudante para confirmar minha condição.

Para as entrevistas, utilizei o mecanismo de entrevistas em profundidade semiestruturadas, ou seja, mesmo sabendo que a entrevista poderia chegar a pontos inesperados, a depender das respostas, eu fiz um roteiro prévio (Anexo 3), que possui três partes principais: a primeira para identificação e história de vida; a segunda para opiniões sobre a dinâmica e a prostituição na W3 norte; e a terceira para temas livres que as entrevistadas gostariam de relatar ou ressaltar. Mas é importante esclarecer que não foi em todas as oportunidades que consegui exaurir esse roteiro, sendo às vezes a entrevista era interrompida por um programa com um cliente ou também por terceiros, ou simplesmente tomava rumos inesperados.

Antes de conversar com as prostitutas, além de ter tido acesso a uma extensa bibliografia específica e também já ter feito outros trabalhos sobre o tema, fiz várias observações na avenida W3 norte para me familiarizar com o espaço e as situações. Das 10 prostitutas cujos relatos transcrevi com detalhes, três delas eram travestis, e, mesmo tendo ciência de que há peculiaridades e diferenças entre a prostituição de mulheres e de travestis, resolvi manter meus registros pela riqueza de informações. Além disso, confesso que essa questão de gênero (travesti ou mulher) não foi objeto de maiores preocupações para mim, mesmo porque eu apenas percebi que se tratava de travesti depois de mais de vinte minutos de

138 "Pista", categoria nativa que se referente à prostituição. 
conversa e porque elas próprias me contavam, já que, para mim, até aquele momento, eram mulheres como quaisquer outras.

As entrevistas foram muito ricas e variadas. Diante disso, ao invés de apresentar cada uma das entrevistas individualmente, decidi agrupá-las por temas, de forma a harmonizá-las ou não com as demais observações sobre a prostituição na W3 norte feitas.

Os grupos selecionados foram: apresentação pessoal, a atividade profissional, a prostituição na visão das entrevistadas, a questão dos clientes, vulnerabilidades e perspectivas.

\section{Quem são as prostitutas da W3 norte?}

Como disse, apesar de ter conversado com várias prostitutas, fiz um relato mais detalhado de entrevistas de apenas 10 delas.

Entre as entrevistadas ${ }^{139}$, não observei, na W3 norte, muitas prostitutas que aparentassem mais de 40 anos. As idades delas, segundo elas mesmas, são entre 25 anos a 38 anos. Mas idade é uma questão delicada para mulheres em geral. Por exemplo, em uma conversa bem mais descontraída, depois de mais de 30 minutos de interação, Priscilla me contou que, na verdade, tinha 37 anos e não os 27 que tinha me dito no início da entrevista, embora eu já desconfiasse desse favorecimento próprio. Aliás, como se verá no próximo capítulo, um policial militar relatou que conhece uma prostituta que trabalha há 19 anos na W3 norte, o que torna possível que existam, na área, prostitutas que ultrapassem o limite etário indicado.

Coisa similar ocorre, no âmbito específico da prostituição, com o nome. Muito provavelmente o nome que elas me forneceram não era o verdadeiro. Mas também não me interessei pela "verdadeira" identidade das entrevistadas. Como dito, não é a questão aqui.

Quanto ao gênero da minha amostra, como já mencionado, três eram travestis. Aliás, surpreendi-me com minha própria habilidade ou inabilidade para a seleção, pois, por três vezes, abordei travestis imaginando serem prostitutas de gênero e sexo feminino. Enfim, como o objeto da pesquisa não é discutir a prostituição específica e particular de travestis, e sim a prostituição de rua na W3 norte, decidi entrevistá-las e consegui várias informações interessantes para refletir sobre o dispositivo, as quais serão tratadas ao longo da exposição. Por ora, fica o registro que os travestis da W3 norte são bastante femininas. Duas delas, só percebi que eram do sexo masculino depois de mais de quinze minutos de entrevista.

\footnotetext{
${ }^{139} \mathrm{O}$ perfil das entrevistadas encontra-se no Anexo 2.
} 
Interessante notar que apenas os travestis me relataram viver em relação estável de casamento com seus parceiros, que, aliás, sabiam da sua atividade de prostituição. A grande maioria das garotas de programa estava solteira. Entre elas, apenas uma tinha um namorado fixo, que, por sua vez, não sabia da sua atividade como prostituta. Algumas chegaram a reclamar no sentido de que não existiria parceiro que aceitasse uma companheira prostituta. Por sua vez, os travestis me contaram que seus companheiros exercem ou já exerceram a atividade de prostituição, de forma que eu tive a impressão de se tratar de prática mais comum entre eles e mais compreensível na convivência do casal.

Sobre a cidade de origem das prostitutas, apenas uma tinha residência fixa na Asa Norte. Todas as demais vinham de cidades próximas a Brasília, como Sobradinho, Guará, Taguatinga, Itapoã, Valparaíso de Goiás e também de Goiânia. Todas alugavam quartos pequenos $\operatorname{logo}$ em frente a seu ponto de prostituição, os chamados "ambientes ${ }^{140}$ próprios". As que moravam no Guará, Sobradinho, Taguatinga, vinham para pista todos os dias e voltavam às suas casas, já que a distância é bem menor quando comparada à Valparaíso de Goiás e Goiânia ${ }^{141}$. Aquelas que moravam nesses últimos lugares iam para casa apenas nos fins de semana, o que justificaria, ao menos em parte, a drástica redução de movimento da prostituição que observei durante os finais de semana. Quanto àquelas que moravam mais perto, nas cidades-satélites de Brasília, elas ou tinham filhos para cuidar ou estudavam em faculdade, e vinham para a "pista", para a W3 norte, depois de suas atividades escolares.

Mostra-se relevante que uma representação social comum sobre o porquê de as mulheres se prostituírem não se confirmou. Com exceção dos travestis, quatro das sete mulheres entrevistadas, disseram não possuir filhos e que estão na prostituição para "pagar pelos seus luxos", pagar a faculdade, ou mesmo porque as demais opções que possuem no mercado de trabalho remuneram muito mal, comparado ao que podem ganhar na prostituição. Priscilla, 37 anos, disse-me que, antes de decidir se prostituir, era confeiteira de padaria e que trabalhava oito horas por dia, acordava às 5 h00 da madrugada para trabalhar e ganhava um salário mínimo ${ }^{142}$. Ela me disse que com a prostituição, mesmo em tempos de crise econômica como passa o Brasil agora, ela consegue cerca de $\mathrm{R} \$ 4.000,00$, o que é suficiente para pagar o aluguel do "ambiente", comprar roupas e ainda mandar um dinheiro para sua

\footnotetext{
${ }^{140}$ Ambiente, categoria nativa, é o termo usado para se referir ao espaço onde é prestado o programa, ou seja, a relação sexual com o cliente. Geralmente, são quitinetes alugadas em frente ou bem próximas ao ponto de prostituição, integrando a categoria pedaço, já mencionada no capítulo 1.

${ }^{141}$ Para se ter uma ideia dos deslocamentos, temos as seguintes distâncias tendo como referência Brasília, Goiânia (209 km), Valparaíso de Goiás (44 km), Sobradinho (13 km), Guará (13 km) e Águas Lindas $(50 \mathrm{~km})$.

${ }_{142}$ À época da entrevista, junho de 2016, o salário mínimo vigente era de $\mathrm{R} \$ 880,00$ mensais, conforme o Decreto $8.618 / 2015$.
} 
filha. Priscilla ressaltou, contudo, que o dinheiro ganho com a prostituição não é um "dinheiro fácil", ao contrário do que muitos pensam, mas é um "dinheiro rápido". Ela disse que não é viciada em drogas, mas às vezes, usa maconha para ajudar a relaxar a tensão de sua atividade e bebe socialmente.

Por outro lado, Letícia, 30 anos, disse que se prostitui para garantir uma vida melhor para seus dois filhos, que, durante sua atividade noturna, ficam com uma babá paga por ela, para a qual justifica que está trabalhando como enfermeira. Letícia mora em Sobradinho e seus dois filhos estudam em colégios privados. Ela relatou que conta para a babá que é enfermeira, não por temer preconceitos sobre sua atividade, já que sua família sabe da prostituição, mas para que a babá não reivindique aumento salarial por pensar que ela aufere renda maior do que a de uma enfermeira. Letícia disse que, por enquanto, não tem projetos de deixar a prostituição, principalmente, nessa época de crise econômica, e com o que recebe ela consegue arcar com o orçamento familiar.

Renata, 25 anos, solteira, moradora do Guará, sem filhos, foi a que disse que se prostitui para pagar "seus luxos", os quais seriam festas e roupas de grife, já que seus pais são responsáveis por pagar sua faculdade de Direito, onde ela cursa o $6^{\circ}$ semestre. Ela vem de ônibus todas as noites, de segunda-feira a sexta-feira, do Guará para a W3 norte para trabalhar como prostituta e fica na pista até $00 \mathrm{~h} 00$, quando passa o último ônibus de volta para o Guará, cidade-satélite de Brasília, a cerca de 20 quilômetros de distância. Segundo ela, sua família nem pode imaginar que ela se prostitui.

Situação um pouco semelhante é a de Carol, 23 anos, que mora com a mãe em Valparaíso de Goiás, e, durante a semana, vive em uma quitinete, seu ambiente, na Asa Norte. Ela disse que entrou para a prostituição há um ano, desde que seu pai faleceu, a fim de arcar com os custos da faculdade de Direito, mas que, às vezes, fica tão cansada à noite, que nem vai às aulas. Ela tem um namorado fixo, e ele e sua mãe nem sequer imaginam que ela está na pista. Carol me disse que um de seus maiores temores é encontrar algum conhecido na pista, muito mais que a vulnerabilidade a que fica exposta à violência urbana.

Layane, 22 anos, travesti, casada, disse que o mercado da prostituição lhe garante conforto financeiro e que, com as rendas auferidas, já conseguiu construir uma casa para sua mãe em Águas Lindas, um município goiano do entorno de Brasília. Ela pensa em sair da prostituição, porque "não terá sua juventude para sempre", e guarda dinheiro para, no futuro, montar um negócio, talvez um restaurante, com o marido, que também se prostitui. Sua família sabe sobre sua atividade de prostituição. 
Para Bel, 20 anos, solteira, a prostituição é uma alternativa ao desemprego. Ela é técnica em necropsia e sonha com uma vaga no serviço público, mas ainda não conseguiu. Durante a semana, ela mora no "ambiente" que aluga na quadra 707 norte, e aos finais de semana vai para a casa dos pais em Goiânia, os quais pensam que ela trabalha em lojas na Capital Federal e não sabem de sua atividade noturna.

Mônica, 29 anos de idade, mais experiente, na pista há mais de 10 anos, está no $8^{\circ}$ semestre do curso superior de enfermagem, e conta que optou pela atividade de prostituição pela rentabilidade, apesar de a atual crise econômica ter afetado também o "mercado da putaria", ela me contou rindo. Ela é bem articulada, tem posições firmes e estruturadas, e sua família não sabe de sua atividade noturna.

Um dado interessante a se notar é a ideia do "segredo" da atividade de prostituição em relação à família. $\mathrm{Na}$ amostra, todos os três travestis disseram que suas famílias têm conhecimento que eles exercem a prostituição e elas tratam a situação com normalidade. Contudo, entre as mulheres, apenas uma das sete entrevistadas disse que sua família tem conhecimento da sua atividade, e quando eu as questionava sobre isso, elas diziam um "não" com ênfase, ou acompanhado de expressões "imagina", "não tem nem ideia". Naturalmente, esse fato me remeteu à alta carga negativa das representações sociais sobre a prostituição dentro da narrativa moral que recai ainda sobre o papel das mulheres na sociedade. Essa narrativa apresenta as prostitutas como pessoas desacreditáveis e estigmatizadas, de forma a provocar em grande parte das entrevistadas uma situação de permanente tensão, como aquela narrada por Carol, que tinha pânico de encontrar alguém conhecido na pista. Assim, a ideia do segredo se mostra como uma estratégia do sujeito a fim de gerenciar esses riscos de menosprezo, como bem lembrou Goffman:

Uma estratégia amplamente empregada pelo sujeito desacreditável é manusear os riscos, dividindo o mundo em um grande grupo ao qual ele não diz nada e um pequeno grupo ao qual ele diz tudo e sobre o qual, então, ele se apoia; ele opta para exibir sua máscara precisamente àqueles indivíduos que, em geral constituiriam o maior perigo. No caso das relações próximas que ele já tinha na época em que adquiriu o seu estigma, pode imediatamente "pôr a relação em dia" por meio de uma calma conversa confidencial; posteriormente ele poderá ser rejeitado, mas conserva a postura de alguém que se relaciona de maneira honrada (GOFFMAN, 2012, p. 106).

A partir do segredo enquanto categoria de análise, surge naturalmente uma rede de sociabilidade entre aqueles que o compartilham e também são responsáveis pela sua guarda 
conjunta, e "não devem trair os segredos da equipe nos intervalos das representações - quer por interesse pessoal, por princípios ou por falta de discrição", o que foi chamado por Goffman como lealdade dramatúrgica (2013, p. 229). Seria como se a prostituta realmente tivesse que gerenciar, pelo menos, duas vidas, representando papéis diferentes, um em casa e outro na rua, o que demanda habilidades específicas, como disciplina para não cometer atos falhos em palcos diferentes e também presença de espírito "para estar sempre preparado para dar uma razão plausível que justifique o acontecimento da ruptura, uma maneira jocosa de diminuir a importância dela ou uma profunda desculpa" (GOFFMAN, 2013, p. 233). Isso decerto tem repercussões importantes na subjetividade e na construção da narrativa identitária das prostitutas.

Contudo, essa rede de sociabilidade, ao menos pelo que pude observar na prostituição da W3 norte, não é muito ampla, restringindo-se a poucas “amigas”, também companheiras de pista. Como já mencionado no Capítulo 2, a figura do cafetão ou da cafetina, que tem sua dualidade de significados tanto na literatura sobre a prostituição (CAVILHA, 2014) quanto nas narrativas das prostitutas, ora uma postura severa e opressora, ora uma mãe acolhedora, é muito difícil de ser percebida. Durante minhas entrevistas, em apenas um momento, pude inferir a presença da suposta cafetina de Mônica, a prostituta articulada já quase no fim do curso de enfermagem, quando nossa conversa foi interrompida por uma senhora simpática, com um cachorro da raça Yorkshire, em um carro, chamando Mônica, após nossa conversa ter durado mais de 20 minutos. Antes de ir, Mônica, respondendo à senhora que perguntou se eu “era nova na pista”, esclareceu que eu estava lá para fazer pesquisa para a faculdade.

A rede de sociabilidade da prostituição na W3 norte se dá de forma bem restrita. As garotas de programa ficam em seu ponto de prostituição sozinha ou com, no máximo, duas ou três colegas. Apenas em duas situações, fiz as entrevistas com a presença de outra colega e, nelas, pude perceber uma relação de amizade e cuidado entre elas. Nas duas, havia uma prostitua mais velha e outra bem mais nova, o que me pareceu similar a uma relação maternal entre elas. Questionei as entrevistadas sobre a amizade na prostituição e elas disseram que, por vezes, sentem-se muito sozinhas na W3 norte. Priscilla me disse que, durante as madrugadas, ela bebe conhaque para afastar o frio e a solidão da pista e até me convidou para conversar com ela em outras madrugadas.

Além disso, perguntei às entrevistadas se elas sabiam da existência de alguma associação onde elas pudessem discutir suas questões, problemas, reivindicar direitos e melhores condições de trabalho como, por exemplo, distribuição de preservativos, elas disseram que não conheciam, o que confirmou as respostas negativas das delegadas da 
DEAM sobre esse tema. Trata-se de uma característica peculiar da prostituição em Brasília, quando comparada a outros Estados da Federação como, São Paulo, Rio de Janeiro, Rio Grande do Sul e Minas Gerais, por exemplo, que possuem razoável rede associativa em defesa dos direitos das prostitutas ${ }^{143}$.

\section{A prostituição na $W 3$ norte na versão das suas protagonistas}

Apresentadas as nossas protagonistas, vejamos agora um pouco sobre a visão da prostituição na W3 norte por parte das próprias prostitutas que lá a exercem. Para facilitar a abordagem dos vários temas, dividi-os em três grandes grupos: a dinâmica da prostituição na W3 norte, a atividade de prostituição como um trabalho ou uma profissão e as vulnerabilidades da atividade de prostituição.

\subsection{A dinâmica da prostituição na $\mathrm{W} 3$ norte}

Como já vimos, nos Capítulos 1 e 2, a apropriação do espaço pela prostituição na W3 norte, mostra-se peculiar e integrada com os elementos espaciais e sociais da cidade. Assim, um elemento chave da dinâmica da prostituição na W3 norte é compreender, a partir das observações e das entrevistas realizadas, como as prostitutas obtêm os seus "ambientes", e como esses locais se relacionam com o lugar que cada uma delas ocupa na avenida, de forma a tornar-se seu ponto de prostituição ou "seu pedaço". Como já observado e segundo grande parte das entrevistadas, o local onde cada prostituta fica na pista é uma projeção do local onde fica o seu "ambiente" alugado.

Nesse sentido, Carol e Priscilla esclareceram que é muito difícil alugar apartamentos na W3 norte, uma vez que a maioria dos proprietários proíbe a prática da prostituição por parte dos seus inquilinos. Segundo elas, essa proibição não vem expressa no contrato de locação, mas sim por meio de uma cláusula muito sútil, dizendo que é proibida a prática de qualquer atividade econômica no imóvel. Então, imóveis disponíveis que restam são bem disputados. Elas relataram também que algumas prostitutas preferem alugar quartos nas pousadas mencionadas, pelo valor aproximado de $\mathrm{R} \$ 400,00$, por semana.

\footnotetext{
${ }^{143}$ No Rio de Janeiro, há a associação da Vila Mimosa, fundada em 1988, que surgiu do movimento "O mangue resiste", e também a DaVida - Prostituição, Direitos Civis, Saúde, fundada em 1992. No Ceará, há a Associação das Prostitutas do Ceará - APROCE, fundada em 1990, responsável pela coordenação da Região Nordeste da Rede Brasileira de Profissionais do Sexo. No Pará, em 1990, foi fundado o Grupo de Mulheres Prostituas da Área Central. Também em 1990, em Sergipe, foi fundada a Associação Sergipana das Prostitutas - ASP. Em Porto Alegre, foi criado o Núcleo de Estudos da Prostituição NEP, em 1993. Em Minas Gerais, há a Associação das Profissionais do Sexo de Belo Horizonte - ASP/BH, e também o Núcleo de Pesquisa e Extensão em Psicologia Política (NPP) da Universidade Federal de Minas Gerais (UFMG). (SANTOS, 2011, p. 69-71).
} 
A partir dessas informações, é possível refletir que o mercado de "ambientes" é bastante limitado, e está sob o controle de poucas pessoas, que, regra geral, têm consciência de que seus imóveis são destinados à prostituição, tanto que cobram das prostitutas valores bem acima do preço de mercado e aparentemente não incluem a referida cláusula nos contratos.

As descrições de Carol e Priscilla coincidem com o relato de Vanessa, quando ela narra como a prostituta deve proceder para começar a trabalhar na W3 norte. Segundo ela, inicialmente, a candidata deve conversar com uma "mulher", que pode ser a que aluga quartos ou uma prostituta mais velha que apresenta a novata às colegas. Assim, percebe-se a partir da fala de Vanessa que existe uma "mulher" que aluga os "ambientes" para as prostitutas na W3 norte, e que a autorização dela era suficiente para que a pessoa começasse a trabalhar como prostituta na região. Contudo, ao tentar saber mais sobre essa "mulher" ou "pessoa" responsável pelos alugueis dos quartos, as garotas de programa desconversavam, mostrandose esse assunto como um interdito.

Nas minhas observações no campo, por duas vezes, acredito que tenha me deparado com pessoas que trabalhavam junto às prostitutas. Na primeira oportunidade, enquanto caminhava à noite pela avenida, avistei um homem que constantemente fazia anotações e conversava com as prostitutas, e as conduzia pelo braço para um lugar reservado. Em outra, uma senhora com um cachorrinho no braço que interrompeu a minha conversa com Mônica e Bia. Tanto o homem das anotações quanto a mulher do cachorrinho pareciam estar fiscalizando as prostitutas. Uma hipótese seria que eles trabalham para os tais donos dos "ambientes" e que, nessa hipótese, funcionariam como autênticos cafetões, mas nada nas minhas observações e entrevistas puderam confirmar minhas inferências, mesmo porque esse é um assunto interdito, como visto.

Nesse contexto, sabe-se, apenas, que existe um conjunto de atividades subjacentes à prostituição, mas, como muitas dessas atividades são criminalizadas, somente é possível observá-las de relance ou por indiscrições ou sinais captados na fala das prostitutas. Contudo, é inegável que os proprietários desses "ambientes" têm grande influência na dinâmica da prostituição na W3 norte. E também extraem relevante vantagem econômica dessa atividade.

Ainda sobre a dinâmica de poder na W3 norte, pela fala de Vanessa, as prostitutas mais antigas na região possuem também influência sobre a atividade das demais, pois teriam certa ingerência na "permissão" para que uma novata passe a trabalhar na avenida. Pode-se perceber uma rede de relações ou sociabilidade, no mínimo de convivência, entre as prostitutas da W3 norte, da qual decorreria essa suposta autoridade das prostitutas mais antigas na região. A existência dessa rede me foi confirmada, quando a própria Vanessa me 
relatou que havia um grupo de conversa em um aplicativo de celular, por meio do qual elas poderiam relatar rapidamente, umas para as outras, sobre qualquer anormalidade, como a presença de algum cliente especialmente agressivo.

Observei ainda que, no final da madrugada, encerrado o seu horário de trabalho, as prostitutas tendem a se agrupar em torno de umas poucas barracas que vendem comida, barracas de cachorro-quente, onde aparentemente também se socializam. Nada muito diferente do que acontece em outros ramos de trabalho, com os seus happy hours.

Quanto aos valores auferidos pelas prostitutas, o preço médio do programa na avenida é R\$ 70,00, como relataram Letícia, Bel, Mônica e Bia, com a duração de 20 minutos, e direito a sexo oral e vaginal, mas esse preço é negociável. Atividades mais simples, como um programa apenas com sexo oral, podem ficar por $\mathrm{R} \$ 40,00$ ou $\mathrm{R} \$ 50,00$. Por outro lado, o programa pode chegar a $\mathrm{R} \$ 80,00$, no caso de sexo anal, como explicou Priscilla, sem a possibilidade de desconto. Ademais, de acordo com Mônica, esse valor alcança R $\$ 300,00$, para atividades com casais, que podem durar até uma hora. Layane, que é um travesti, é a que cobra o valor mais alto entre as entrevistadas: $\mathrm{R} \$ 150,00$ por programa individual. De toda forma, esse valor está muito abaixo daquele que Mônica diz que ganhava quando trabalha em uma boate da Asa Sul: $\mathrm{R} \$ 1.200,00$ por programa.

Sobre a frequência dos programas, Renata e Layane relataram que chegam a fazer 04 ou 05 programas por noite. Mônica e Bia destacaram que a crise econômica afetou profundamente o que elas chamam de "mercado da putaria", e há dias em que simplesmente não conseguem trabalho. Foi a crise econômica, aliás, que levou Mônica a trocar a boate pela "pista", pois nesta os programas eram mais frequentes, embora mais baratos, o que the trouxe maior segurança, no que tange à sua renda mensal.

Nesse contexto, a média renda das prostitutas, parece estar entre $\mathrm{R} \$ 3.000,00$ e $\mathrm{R} \$$ $5.000,00$, numa média de $\mathrm{R} \$ 4.000,00$, por mês, como se extrai das entrevistas de Priscilla, Layane, Carol, Letícia e Vanessa. Com essa renda, elas cuidam de todas as suas necessidades, como moradia, comida e cuidados estéticos, e ainda conseguem poupar algum dinheiro para ajudar a família, planejar o futuro ou ainda gastar em roupas e baladas.

Mostra-se relevante notar que uma parte significativa dessa renda mensal é consumida pelo pagamento do aluguel para os proprietários dos “ambientes". Renata relata que paga R\$ 1.600,00, e Priscilla, R $\$ 2.200$, por mês. Já Carol paga R $\$ 250,00$ por semana, ou aproximadamente $\mathrm{R} \$ 1.070,00$ por mês, por um pequeno quarto, sem banheiro, no apartamento que divide com Priscilla. Bia destaca que há ambientes que custam $\mathrm{R} \$ 50,00$ por dia, o que alcança por volta de R\$1.500,00. Já nas pousadas, que, segundo Carol e Priscilla, 
cobram $\mathrm{R} \$ 400,00$ por semana, para alugar quartos para prostitutas, o custo mensal chegaria a aproximadamente $\mathrm{R} \$ 1.700,00$ por mês. Tomando em conta todas essas quantias, chega-se ao valor de R\$ 1.914,00, como valor médio do aluguel dos "ambientes" na região da W3 norte. Ou seja, por meio do pagamento dos aluguéis, os proprietários dos "ambientes" ficam com parte considerável da renda das prostitutas, podendo chegar até a mais da metade do valor que elas conseguem com o seu trabalho, o que reforça ainda mais a sua importância para a dinâmica da prostituição na W3 norte.

Como parâmetro de comparação, em uma pesquisa no site Wimóveis ${ }^{144}$, foram encontradas quitinetes mobiliadas para alugar, na 707 norte, no valor de R \$ 800,00 por mês, muito abaixo, assim, dos valores cobrados das prostitutas por um imóvel similar. Já na área da 704/705 norte, encontram-se quitinetes por valores entre R \$ 800,00 e R \$ 950,00. Há também, na área da 704/705 norte, quitinetes cujo aluguel chega a $\mathrm{R} \$ 1.500,00$, mas em prédios mais sofisticados, distantes do perfil de imóveis que, regra geral, são utilizados como ambientes pelas prostitutas da W3 norte ${ }^{145}$. Diante do descompasse entre esses preços, e os cobrados das prostitutas, supõe-se ser pouco provável ${ }^{146}$ que os proprietários dos ambientes não tenham conhecimento da sua destinação.

Assentado esse ponto, observa-se que das prostitutas que entrevistei, várias atuam tanto de dia quanto de noite. Tanto Letícia quanto Vanessa relatam que, durante o dia, atendem os seus clientes fixos, os quais lhes chegam também por meio dos anúncios que elas colocam na internet, em sites especializados de prostituição ${ }^{147}$. Já à noite trabalham na avenida.

Carol afirma que, durante o dia, atende os clientes que consegue por meio de publicidade realizada em sites, e à noite, trabalha na $\mathrm{W} 3$ norte. Todavia, teve pouco retorno da

\footnotetext{
${ }^{144}$ No site www.wimoveis.com, anuncia-se imóveis para alugar e vender, principalmente na área do Distrito Federal. Ele permite a utilização de filtros para delimiter as buscas, entre eles, por bairro e tamanho.

${ }^{145}$ A data da consulta desses preços foi 28/09/2016.

${ }^{146}$ Como se viu, o dispositivo é composto de ditos, interditos e não ditos. Do ponto de vista metodológico, a apreensão dos ditos é a que apresenta menos dificuldades metodológicas, embora elas existam. Mais complexa é a observação dos interditos e dos não ditos, cada um por uma razão distinta. Os interditos são ditos cuja menção, especialmente fora do grupo, é proibida por qualquer motivo. É o caso, por exemplo, de práticas consideradas como crime, como ocorre com o cafetão. Já os não ditos são dimensões do dispositivo que não são sequer formuladas pelo sujeito. Dito isso, pergunta-se: como apreender o interdito e o não dito? Perguntas diretas não são suficientes para tanto. É necessário, então, recolher pistas e rastros dessas falas e práticas e tentar ler nas entrelinhas, relacionando esses indícios, para então se obter um conhecimento mais apurado dessa parcela do dispositivo. Contudo, sabe-se que dificilmente o dispositivo possa ser apreendido por inteiro, tendo em vista seus elementos subjetivos e psíquicos, como a questão do segredo na atividade de prostituição. Isso conduz a um outro problema: na momento que essa análise é formulada, ela passa a fazer parte do dispositivo, modificando-o. O ato de analisar o dispositivo (re)cria o próprio dispositivo, até mesmo pela sua característica de dinamicidade, como se viu no capítulo introdutório. Assim, a partir do momento que passei a observar a dinâmica da prostituição na W3 norte e as narrativas desenvolvidas sobre ela, e a formular hipóteses sobre essas observações, eu modifiquei, ao menos em parte, o dispositivo que trata desse assunto, acrescentando a ele mais um elemento (minhas observações e hipóteses sobre o assunto) que já nasce entrelaçado com todos os demais na polifonia que é o dispositivo. Ou seja, esta pesquisa é parte do dispositivo, assim como a interpretação que os leitores, inclusive você, fazem deste trabalho.

${ }^{147}$ Em Brasília, dois sítios eletrônicos destacam-se no mercado da prostituição: www.capitalsex.com, cujo proprietário entrevistei, como se verá no capítulo seguinte, e o www.socinquenta.com. Há também um fórum onde os clientes trocam impressões sobre o desempenho das prostitutas, o www.gpguia.com.
} 
divulgação do seu trabalho em sites, apesar do elevado investimento, consubstanciado em R\$ 200,00 para fazer e colocar as fotos no site, e $\mathrm{R} \$ 400,00$ para dar destaque a essas fotos no site por 3 semanas. Porém, a maioria das entrevistadas informou que não faz uso de divulgação em sites ou mesmo em jornais. Nesse ponto, algumas informaram que receiam que, com a publicidade, possam ser reconhecidas por amigos e familiares. Essa preocupação indica o realismo com que as prostitutas tratam o estigma da sua atividade, e a opção que a maioria faz, no sentido de se submeter a uma vida dupla, para evitar sofrer alguma discriminação por conta do seu trabalho.

Ao longo das minhas observações, como visto acima, notei que há muito mais prostitutas na W3 norte durante a semana, do que nos fins-de-semana. Carol e Priscilla explicaram que, durante a semana, há mais programas, porque os homens casados fazem programas rapidamente, em 20 minutos, e, podem ter facilmente a justificativa do excesso de trânsito na cidade ou o excesso de trabalho após o expediente para justificar sua ausência para as famílias, conforme abordado anteriormente. Essa dinâmica reforça a visão, já tratada anteriormente no Capítulo 1, de que o mercado da prostituição na W3 norte funciona como um enorme drive-thru, onde os clientes, em seus carros, entram e saem dos estacionamentos, observando aquilo que está disponível, e, quando escolhem o "produto" que querem, podem consumi-lo com rapidez e discrição, normalmente no próprio ambiente da prostituta, que fica próximo dos locais de exibição, ou vitrines. De acordo com Layane, é normal os clientes pararem, fazerem uma série de perguntas para ela, pedindo inclusive para ver partes do corpo, como os seios, irem embora, e, depois de pesquisar mais um pouco, retornarem para fechar o negócio e fazer o programa.

Apresentada nessas linhas a perspectiva das prostitutas sobre a dinâmica da prostituição na W3 norte, passemos agora a examinar em que termos elas enxergam a sua própria atividade profissional.

\subsection{A prostituição como um trabalho, uma atividade profissional}

A partir da conversa com as entrevistadas, pude observar que elas consideram sua atividade como um trabalho, no qual há vantagens e desvantagens. Várias delas enxergam a prostituição como uma alternativa para empregos em que elas trabalham muito mais e recebem bem menos. Nenhuma delas disse que a prostituição é fácil, e a maioria enfatizava que a remuneração na prostituição não é um "dinheiro fácil", como muitas pessoas pensam, mas apenas que é um "dinheiro rápido", que elas podem ter acesso em momentos de urgência. 
Na W3 norte, as prostitutas têm uma relação bem profissional com a atividade de prostituição. Nota-se o cuidado na escolha das vestimentas, a preocupação com a proteção contra doenças, o trato educado e chamativo com os clientes. Por exemplo, Carol, de 23 anos, que estava de saia curta, botas, cabelos escovados, lingerie um pouco à mostra, e maquiagem. Disse que ela e Priscila, 38 anos, sempre compram calcinhas sensuais para o trabalho de uma mulher que é fornecedora para todas as garotas de programa da W3 norte. Inclusive, durante minhas entrevistas preliminares em 2015, cheguei a encontrar com a fornecedora de calcinhas sensuais, cada uma custava $\mathrm{R} \$ 20,00$.

As prostitutas da W3 não se preocupam apenas com a aparência física, mas também com o trato com o cliente. Mônica, 38 anos, já mais experiente, me disse que ela tem toda uma "psicologia" para lidar com o consumidor dos seus serviços. Ela mesma se classifícou como sendo brava, às vezes até grossa, mas ela disse que essa seria a marca dela com os clientes, que, segundo ela, adoram. Ela me contou várias situações inusitadas que já passou nesses mais de 10 anos de prostituição. Disse que a demanda dos homens é bastante variada, vai desde a atividade sexual em si, em modalidades tradicionais, vaginal, oral e anal, a fantasias eróticas não convencionais como a prática da "chuva negra" e da "chuva dourada"148, atos que, segundo Mônica, ela pratica sem problemas, mas cobra mais caro. Mônica contou que ela possui um cliente que a paga bem para "apenas" andar sobre suas costas de salto alto. Ela disse que essas fantasias inusitadas são muito comuns e que a "vida real era muito mais rica que as histórias contada pela Bruna Surfistinha ${ }^{149}$ ".

Além disso, Mônica ressaltou que a prostituta deve, segundo ela, ter "uma psicologia própria”, para atender aos desejos do cliente. Muitos vêm até ela para conversar sobre seus problemas conjugais com as esposas e companheiras, pedindo-lhe sua opinião sobre a relação conjugal ou mesmo dicas para a melhoria do desempenho sexual com as parceiras ou em geral. Assim, Mônica ressaltou a paciência e a naturalidade como características de uma boa prostituta.

A paciência também é vista como uma característica na prostituição para Bia, que contou que há clientes que a procuram para desabafar os problemas com suas esposas, e também, novamente, para perguntar sobre a qualidade do seu desempenho sexual. Há ainda

\footnotetext{
${ }^{148}$ Chuva dourada é o nome popular para a urofilia uma variante da sexualidade, ou parafilia ou fantasia sexual, que consiste na excitação ao urinar no parceiro ou receber dele um jato urinário, ingerindo-o ou não. A chuva negra, também uma variante da sexualidade ou fantasia, cujo nome técnico é coprofilia, é a excitação por cheirar, ingerir ou manipular fezes ou simplesmente observar alguém defecar. Fonte: http://www.malthus.com.br/mg_total.asp?id=14 Acesso em 02/10/2016.

${ }^{149}$ Bruna Surfistinha é o pseudônimo e o "nome de guerra" utilizado por Raquel Pacheco, quando foi prostituta durante três anos em São Paulo. Raquel ganhou fama com um blog na internet no qual narrava seu cotidiano como prostituta e detalhes dos programas que realizava e também com a publicação de sua autobiografia, "O doce veneno do escorpião - o diário de uma garota de programa", no qual ela contava as histórias postadas em seu blog.
} 
aqueles que, segundo ela, querem saber sua opinião sobre se a sua esposa o está traindo ou não. Layane relata as mesmas experiências, em que teve que funcionar como "psicóloga" de seu cliente, sentimento esse compartilhado por Bia e por Mônica. Essas falas confirmaram-se quando conversei com clientes, cujas entrevistas tratarei no capítulo seguinte.

Interessante observar nesse ponto, duas representações recorrente no imaginário social: uma relacionada à figura da mulher, que deve ser paciente, acolhedora; e outra à imagem do homem, do qual se espera virilidade e um potente desempenho sexual, não podendo expressar suas fragilidades em público. Esse contexto traz uma compreensão aprofundada das falas de Bia e Layane, cujos clientes buscam um ambiente de clandestinidade, para somente nesse local confessar as suas inseguranças sexuais e problemas pessoais. Fazem isso, porque a prostituta, regra geral, é alguém absolutamente apartada do seu mundo social, resguardando sua identidade masculina viril. Há, assim, entre cliente e prostituta uma relação de confiança ao anonimato recíproco.

A garantia do anonimato também levaria os clientes ao mercado da prostituição para a realização de suas mais variadas fantasias sexuais ${ }^{150}$. Aliás, uma das entrevistadas, $\mathrm{Su}$, descreveu o trabalho de prostituição precisamente como "vender fantasias". 151

Mônica ainda me contou que um grupo de clientes que busca os serviços das prostitutas da W3 norte são os homossexuais masculinos, principalmente para a prática do chamado "fisting" que consiste na atividade de inserir o braço no ânus da outra pessoa. Talvez essa demanda decorra da pouca incidência de prostituição de rua de pessoas com o fenótipo masculino, ao menos na região do Plano Piloto de Brasília, o que leva essas pessoas a procurarem os serviços de prostitutas mulheres, como substitutivo.

Observa-se que a maioria das práticas relatadas são fantasias tidas como inaceitáveis no campo social usual, e, portanto, o cliente busca um espaço clandestino para realizá-las. Afinal, o consumo público dessas fantasias provavelmente conduziria à estigmatização do próprio adepto desse tipo de prática.

Nesse sentido, a demonstração de paciência e capacidade de realização de fantasias eróticas, inclusive, constam como atributos profissionais da prostituta, segundo a Classificação Brasileira de Ocupações (CBO) $n^{0}$ 5198-05, vinculada ao Ministério do

\footnotetext{
${ }^{150}$ Um dos clientes com quem conversei me contou uma história bem incomum, que ele soube por uma prostituta amiga sua, e que ilustra essa questão da fantasia sexual. De acordo com ela, um cliente teria pedido à prostituta que levasse um cachorro de grande porte para o seu "ambiente", para que ele, o cliente, mantivesse sexo anal com o animal, assumindo o primeiro o papel "passivo". A prostituta recusou-se a assistir a cena.

${ }^{151}$ Por vezes, essas fantasias são simples, como ficar observando a prostitutas caminhar nua pelo quarto de salto alto, como relatou Bia. Em outros casos, essas fantasias são mais ousadas, como na vez em que, a pedido de um cliente, Mônica deu um soco na boca deste, quebrando um dos seus dentes. O cliente gozou na hora, segundo ela.
} 
Trabalho e do Emprego, que regulamentou a atividade dos profissionais do sexo, dentro das categorias de trabalhadores dos serviços, vendedores do comércio em lojas e mercado, depois de várias reivindicações dos movimentos associativos de prostituição no Brasil. Segundo o próprio Ministério do Trabalho, o conceito de ocupação tem duas dimensões, um referente ao nível de competência, uma série de atividades com complexidade e responsabilidades específicas, e outro, consistente em certo domínio ou especialização de competência em exercício de atividade econômica. ${ }^{152}$

Na CBO 5198-05, além das citadas, destacam-se como "competências" esperadas do profissional do sexo: capacidade de persuasão, capacidade de expressão gestual, agir com honestidade, planejar o futuro, prestar solidariedade aos companheiros, ouvir atentamente (saber ouvir), capacidade lúdica, respeito ao silêncio do cliente, capacidade de comunicação em língua estrangeira, ética profissional, sigilo profissional, capacidade de proporcionar prazer de conquistar o cliente e manter a higiene pessoal. São características compatíveis com aquelas mencionadas por todas as entrevistadas.

Aliás, essas habilidades específicas para a prostituição são muito antigas, conforme nos relata Sennett, citando Pietro Arentino:

Aprendi em um mês tudo o que há para saber sobre o meretrício: como despertar paixão, atrair homens, dominá-los, levando-os a crer que são os únicos. Como chorar quando quero rir e como rir quando tenho vontade de chorar. E como vender minha virgindade várias e várias vezes". Tornar-se uma cortesã exigia muito mais. Era preciso estabelecer uma rede de clientes de alta classe, adquirir uma casa e roupas que os agradassem e conhecer os mexericos da cidade, para diverti-los (SENNETT, 2003, p. 199).

A ideia de vender a virgindade "várias vezes" foi mencionada por Priscilla, que me disse, ao lado de Carol, que elas usam algumas estratégias para ficar "virgem" novamente, como um chá de uma folha da árvore barbatimão, que segundo elas tem efeito cicatrizante e faz a vagina ficar mais apertada. Carol, que tem namorado fixo, disse que usa esse truque para que ele não desconfie de sua atividade na prostituição. Ainda sobre essas estratégias profissionais, questionei-lhes se elas fazem programas quando estão menstruadas, e elas

152 "O título ocupacional, em uma classificação, surge da agregação de situações similares de emprego e/ou trabalho. Outros dois conceitos sustentam a construção da nomenclatura da CBO 2002: Emprego ou situação de trabalho: definido como um conjunto de atividades desempenhadas por uma pessoa, com ou sem vínculo empregatício. Esta é a unidade estatística da CBO. Competências mobilizadas para o desempenho das atividades do emprego ou trabalho. O conceito de competência tem duas dimensões: Nível de competência: é função da complexidade, amplitude e responsabilidade das atividades desenvolvidas no emprego ou outro tipo de relação de trabalho. Domínio (ou especialização) da competência: relaciona-se às características do contexto do trabalho como área de conhecimento, função, atividade econômica, processo produtivo, equipamentos, bens produzidos que identificarão o tipo de profissão ou ocupação." Disponível em: http://www.mtecbo.gov.br/cbosite/pages/informacoesGerais.jsf Acesso em 02/10/2016. 
falaram que fazem, sem qualquer problema, porque elas colocam um chumaço de algodão na vagina de forma que não há qualquer passagem de sangue. Elas me contaram essa técnica de forma tão natural que me pareceu ser uma prática comum na profissão.

A relação com os clientes também é bastante profissional e elas não relatam ter muitos problemas. Em geral, o programa dura cerca de 20 a 30 minutos, a negociação é antecipada sobre o que está ou não incluso, junto com o pagamento. Assim, como as entrevistadas disseram cobrar o programa adiantado, elas não me relataram muitos problemas por falta de pagamento, de modo a se tornar necessária a intervenção de um terceiro ou mesmo da polícia militar ou até idas a delegacia de polícia, conforme mencionado no capítulo anterior.

Um dos grandes obstáculos na discussão do reconhecimento da atividade de prostituição como atividade profissional é a ideia muito difundida de que ela consubstanciaria a objetivação do corpo feminino, que, na figura da mulher prostituta, estaria reduzido a mero instrumento de satisfação do desejo sexual masculino, o que, de acordo com o entendimento tradicional, estaria em contradição com a dignidade da sua condição humana. Esse é o pensamento corrente de algumas feministas que se intitulam radicais (McKinnon e Dworkin, 1988), conforme já tratado na introdução desse trabalho e que será tratado com maior profundidade no Capítulo 5 desta dissertação.

Contudo, essa posição teórica não encontrou eco nas representações das prostitutas que entrevistei. Questionei-lhes se elas se sentiam como um objeto, durante a prestação do serviço de prostituição, se elas entendiam sua atividade como uma venda do corpo e todas elas foram unânimes em rechaçar essa visão. Algumas delas até riram, e Mônica respondeu minha questão com uma pergunta: "Você se sente objeto quando você dá de graça?" Eu, sem reposta, ri junto com ela. Outras, como Renata e Letícia, disseram que, na opinião delas, objetos são as "piriguetes", referindo-se às mulheres que mantém relação sexual com os homens em troca de presentes caros e jantares. A maioria delas ressaltou que vê a atividade de prostituição como um trabalho, de onde retira seu sustento e de sua família.

Sem dúvida, as entrevistadas gostariam de ter melhor condições de vida, como a estabilidade e a remuneração de um emprego público, mencionadas por várias delas ${ }^{153}$. No entanto, elas enxergam a prostituição como a melhor possibilidade entre as que lhes são concretamente possíveis, em especial quando comparam a contrapartida financeira com a quantidade de esforço físico e mental que cada uma dessas atividades demanda. Muitas

\footnotetext{
${ }^{153}$ Interessante notar que a representação social do concurso público como sinônimo de estabilidade e segurança bem presente na sociedade brasiliense alcança também os sonhos de parte das prostitutas entrevistadas. Inclusive, o entrevistado proprietário de um site de acompanhantes, relatou que algumas de suas clientes deixaram a prostituição porque obtiveram êxito em concursos públicos.
} 
disseram, com convicção, que preferem a prostituição a trabalharem como assalariadas em lojas ou padarias. Priscilla contou que entrou para a prostituição há seis meses depois de ter perdido o horário para chegar para trabalhar em uma panificadora, e que lá trabalhava mais de oito horas por dias e recebia um salário mínimo. Ela esclareceu que a vida na "pista" também tem seus reveses, alguns clientes chatos e bêbados, bem como os riscos com a criminalidade, mas, mesmo assim, opta ainda pela atividade de prostituição, enquanto não aparecem opções melhores.

Feitas essas observações sobre como as prostitutas da W3 norte vêm a sua própria atuação, no próximo segmento, será explorado outro aspecto da atividade de prostituição: as vulnerabilidades das prostitutas a uma série de reveses, como na sua interação com traficantes, cafetões e clientes.

\subsection{Vulnerabilidades da prostituição na $W 3$ norte}

As vulnerabilidades a que são submetidas as prostitutas na avenida W3 norte foram assuntos delicados nas entrevistas, tratados muito mais em "não ditos" e interditos, do que de forma clara e expressa. Considero que trataram de vulnerabilidades falas subentendidas que se referiam à violência contra elas, por parte dos clientes, cafetões, cafetinas, policiais e também entre elas. Além disso, também considerei o envolvimento delas com crimes, sendo autoras, vítimas ou testemunhas, de forma a entender melhor os dados estudados no Capítulo 2, agora contextualizados pelas falas das próprias prostitutas.

Ao perguntar sobre a criminalidade urbana, principalmente relacionada ao tráfico de drogas e às reclamações de alguns moradores nos jornais sobre a região da W3 norte, percebia claramente o desconforto das entrevistadas, de forma que eu imaginei que elas pudessem pensar que eu era uma policial, fazendo tantas perguntas, ou até mesmo que trabalhasse para alguma cafetina com mais poder no local. Assim, quando percebia o desconforto, tentava mudar o assunto para não prejudicar o clima da entrevista.

Contudo, pude notar, nas entrelinhas, alguns fatos interessantes. De fato, nas entrevistas, percebi uma associação espacial entre às quadras iniciais, como elas chamaram as quadras 703/704 norte, com o tráfico ilícito de entorpecentes. As entrevistadas ressaltaram a necessidade de se fazer uma distinção entre o consumo de drogas e a atividade de prostituição, enfatizando que exercem a atividade porque precisam do dinheiro e que se fossem dependentes químicas não conseguiriam atingir seus objetivos financeiros. Contudo, elas disseram que muitas prostitutas indicam aos clientes traficantes de entorpecentes, mas, 
pelo menos as entrevistadas garantiram que, quando são questionadas por seus clientes sobre eventuais pontos de venda de drogas, elas dizem que não sabem, pois não querem problemas nem com traficantes nem com a polícia. Segundo elas, as prostitutas que exercem a atividade no Setor Comercial Sul são dependentes de drogas, principalmente crack, e por isso seus programas são mais baratos.

Como visto antes, de acordo com as entrevistadas, existe uma rede de comunicação entre as prostitutas da W3 norte, por meio de um aplicativo de telefone móvel, em que elas se comunicam facilmente sobre a presença de algum cliente que mostrou um comportamento diferente, perigoso, e também sobre a ação da polícia. Assim, imaginei que minha presença no campo por mais de dois meses já havia sido notada e, por isso, dificilmente, eu teria acesso, por meio das narrativas das prostitutas, a informações sobre a dinâmica das ações de cafetões e traficantes. Porém, o "não-dito" e o interdito têm sua grande importância na construção do dispositivo, conforme tratado na introdução desse capítulo.

No entanto, percebi, nas entrevistas realizadas nas quadras mais altas, como 710 a 715 , uma necessidade das entrevistadas em se diferenciarem das prostitutas que ficam nas quadras 703, 704 e 705, como se aquelas estivessem de alguma forma envolvida com crimes relacionados a drogas. Eu cheguei a perguntar como funcionaria essa dinâmica e apenas Priscilla me disse que há garotas de programa que usam a prostituição para a camuflagem do tráfico de drogas, e essas, ela considera como traficantes, e outras que repassam drogas para seus clientes durante a realização do programa, a pedido dos próprios clientes. Segundo ela, nesse último caso, ela não considera que a prostituta seja traficante. Nota-se, por meio da fala de Priscilla, uma necessidade de categorizar quem é prostituta e quem é traficante, não sendo possível, a partir de sua perspectiva, a convivência das duas identidades.

Inclusive, tive a impressão de ter passado por uma situação semelhante durante a entrevista de Su, travesti, na quadra 703 norte. Quando eu perguntei sobre sua impressão sobre a criminalidade e a prostituição na W3 norte, ela mudou a expressão facial, disse que sua "relação com a polícia é muito boa, porque eles passam todo momento lá", além de ressaltar que a quadra 703 "é muito boa, apesar de outras pessoas dizerem o contrário", ou seja, reconheceu a má fama da quadra. Nossa entrevista foi interrompida nesse momento quando ela me contou que teria que atender um cliente antigo que estava lhe chamando em um carro preto, estilo sedan, com películas muito escuras.

Interessante que durante minha permanência no campo, eu via, com frequência, viaturas da polícia militar passando tanto na avenida W3 norte, de forma mais devagar, quanto entre os estacionamentos onde ficam as prostitutas e também na avenida W4 norte, que fica por detrás 
do ponto de prostituição. Em duas oportunidades, vi, em uma posição mais afastada, uma grande abordagem do Grupo Tático Operacional (GTOP), uma ala da polícia militar destinada a crimes mais graves, como o tráfico ilícito de drogas, exatamente na praça que se localiza entre as quadras 703 e 704, onde há uma concentração maior de pessoas e um movimento constante da prostituição nas pousadas que ficam naquela praça. Nos dias de intensa presença da polícia no local, eu observava o campo apenas do carro e não descia para caminhar e fazer as entrevistas, por medo de ser considerada pelas prostitutas como policial, e, dessa forma, prejudicar a pesquisa.

Algumas entrevistadas também me contaram que, por vezes, os clientes também levam entorpecentes para eles consumirem durante o programa e que, alguns deles, querem que elas também usem. Para não haver controvérsias, muitas delas me disseram que fingem que usam as drogas, principalmente, quando de se trata de crack, porque elas temem o vício.

Sobre a criminalidade relacionada a crimes contra o patrimônio, por exemplo, roubos e furtos, elas disseram que a W3 norte é relativamente tranquila. Priscila foi a única que narrou ter sido assaltada em uma madrugada e disse que o autor levara a sua calcinha, a única coisa que ela tinha, contou rindo. Contudo, apesar de ter sido assaltada, disse não temer novos roubos e brincou "Vai roubar o quê? Só se for meu sutiã, porque a calcinha já me levaram".

Vanessa, travesti, relatou que os "bandidos" respeitam as prostitutas e não mexem com elas. Já Bel, bem mais nova na pista, teme todos os dias que algo de ruim aconteça com ela e por isso ela disse "colocar Deus na frente de tudo" antes de ir para pista.

Questionei-lhes também sobre a relação delas com a polícia e, como disse acima, tive a impressão que elas nada falariam que desabonasse a polícia. Contudo, em conversas com clientes, que serão apresentadas no capítulo seguinte, soube haver até violência sexual contra as prostitutas por parte de policiais que "dão carteiradas" em programa, ou seja, não pagam pelos programas feitos com as prostitutas em razão da sua condição de policial.

Letícia, por exemplo, me disse que sua relação com os policiais é muito boa, porque, para ela "a polícia só vem atrás de traficante" e como ela "não mexe com drogas, nunca teve qualquer problema". Carol e Priscilla disseram que os policiais militares sempre passam por lá, param e perguntam se está tudo bem, nada demais. Contudo, disseram não ter certeza se podem contar com a polícia, porque não sabe se eles virão em situação de emergência. Elas disseram que confiar, confiar mesmo, só em Deus.

Durante o campo, pude observar que, com certa frequência, carros da Polícia Militar e do DETRAN passam pelos estacionamentos da avenida W3, onde ficam as prostitutas, e também pela avenida W3 norte. Interessante notar que o Posto Comunitário de Segurança da 
quadra 714 não possuía qualquer policial nem durante a noite e nem durante o dia, fato que demonstra que o policiamento noturno é apenas móvel.

Quanto à relação com os clientes, as entrevistadas me disseram que a prostituta tem que ter uma postura firme com ele, caso contrário ele pode "folgar", termo utilizado para se referir a algum abuso por parte do cliente, como fazer ou tentar fazer algo além do combinado. Segundo elas, com essa postura, a relação é profissional. Carol e Priscilla me disseram que agindo de maneira séria e firme, o cliente entende o término do programa quando "ele goza" e vai embora sem maiores problemas. Mônica, que admitiu ser mais "brava" com os clientes, me relatou que durante os mais de onze anos de "pista" não teve problemas com eles.

Já as prostitutas travestis me contaram problemas em relação aos clientes quando eles não percebem que elas são travestis e mesmo assim contratam o programa. Alguns tentam agredi-las, mas elas tentam argumentar que o erro foi do cliente. Layane contou que desenvolveu uma estratégia em que ela "entra na cabeça deles e diz que eles que são homens e, por isso, deveriam reconhecer um homem". Assim, segundo ela, eles vão embora sem maiores problemas.

Essa "ausência de problemas" com os clientes narrada pelas prostitutas entrevistadas pode explicar, em parte, o pequeno número de registros de ocorrências policiais nas quais as prostitutas são vítimas de violência por parte dos clientes. Ademais, nenhuma das entrevistadas me disse que já procuraram a delegacia de polícia para resolver qualquer problema com clientes e, quando eu perguntava sobre isso, elas me passaram a impressão de que essa não seria uma conduta adequada no campo da prostituição.

Todavia, há sinais de que, mesmo na fala das prostitutas, há uma "subnotificação" em relação aos crimes dessa natureza, como indicam as entrevistas com os clientes e os policiais, que serão tratadas no próximo capítulo.

Dito isso, passemos, em seguida, a examinar de que forma todas essas falas contribuem para a elaboração do dispositivo de prostituição na W3 norte.

\section{Notas para um dispositivo identitário da prostituição na $\mathrm{W} 3$ norte}

Ao fim dessa seção, acrescento mais notas para a construção do dispositivo da prostituição na W3 norte, agora, com a versão das protagonistas da atividade: as prostitutas. Naturalmente, conforme já considerado, as informações aqui relatadas retratam as representações sociais que as próprias prostitutas da W3 norte possuem sobre seu cotidiano profissional, sobre suas estratégias no exercício da atividade, vantagens e desvantagens. 
Podemos, nesse contexto, observar, a prostituição na W3 norte se dá tanto com mulheres como também com travestis, cujas idades variam, regra geral, entre 18 a 38 anos, não havendo muitas prostitutas com idades mais avançadas. Além disso, a partir das observações e das entrevistas, não foi possível observar uma separação clara entre travestis e mulheres, ainda que espacial, de forma que é fácil confundir um pelo outro, sendo necessária uma pergunta específica ou uma conversa mais demorada para identificá-las.

A atividade de prostituição na W3 norte, em grande medida, é solitária, ou seja, as garotas de programa ficam nos estacionamentos sozinhas ou com pequenos grupos de duas ou três mulheres. Ademais, não contam com associações ou organizações em que possam demandar por melhores condições de trabalho, ou mesmo oferecer um espaço de compartilhamento de problemas, angústias e ideias sobre a profissão, como há em outros Estados do Brasil.

As vulnerabilidades da atividade no que se refere à violência que sofrem tanto de clientes, policiais, da criminalidade urbana, e também de moradores, constitui, ainda um assunto não dito, omitido, sobre o qual elas desconversam, talvez com medo de represálias e também temendo uma possível quebra de sigilo profissional em relação ao cliente, na qual o anonimato apresenta-se como característica chave.

A figura do cafetão ou cafetina também se apresenta com um tema interdito, vedado e tergiversado, mesmo porque, como já analisado, a grande maioria das ações dos personagens que orbitam em torno da prostituição são objeto de criminalização. Mesma situação quando o assunto é o consumo e o tráfico de drogas relacionado à prostituição. As garotas de programa procuram distanciar sua atividade da traficância, identificando e responsabilizando terceiros por eventual venda de entorpecentes.

Finalmente, quanto à identidade da atividade como um trabalho ou profissão, as prostitutas da W3 norte, seguindo a tendência das demais pesquisas recentes realizadas no Brasil $^{154}$, parecem dar um novo significado à prostituição, no sentido de não se tratar de "venda do corpo", que é inalienável, mas sim de prestação de serviços que envolvem muito mais que atividades sexuais, mas também realização de fantasias e suporte psicológico sexual aos clientes. Longe de sentirem-se objeto, as garotas de programa, apesar de desejarem outras oportunidades na vida que não a atividade de prostituição, vêm na pista uma melhor opção entre as que possuem atualmente para futuros ganhos econômicos e sociais.

$\overline{{ }^{154} \text { CAPELA (2013) e TEIXEIRA (2013). }}$ 


\section{Capítulo 4. Elas, segundo os outros}

\section{Percursos metodológicos}

A construção de um dispositivo para a prostituição feminina na W3 norte importa, necessariamente, a consideração dos discursos dos sujeitos diretamente a ela relacionados, conforme já afirmado reiteradamente ao longo desse trabalho (RAFFNSOE, 2008, p. 58). Assim, além de observar o espaço e seus equipamentos urbanos, analisar as ocorrências criminais referentes à avenida W3 e de dar voz às próprias prostitutas, busquei também, por meio de entrevistas semiestruturadas, captar as representações sociais de clientes, policiais militares, policiais civis e profissionais envolvidos com a atividade de prostituição, a fim de acrescentar mais notas ao dispositivo da prostituição feminina na W3 norte.

Ademais, como já tratado tanto na introdução quanto no Capítulo 2, a prostituição, ao lado do crime, é muitas vezes tratada, nas representações sociais, como um desvio. E, segundo o interacionismo simbólico, o desvio não é uma qualidade do ato em si, mas uma consequência da aplicação pelos "outros” de regras e sanções a um infrator. "O desviante é alguém a quem esse rótulo foi aplicado com sucesso; o comportamento desviante é aquele que as pessoas rotulam como tal" (BECKER, 2008, p. 22).

Nesse contexto, considerando que a atividade de prostituição assume no imaginário das representações sociais a condição de desvio social, imprescindível tentar captá-las a partir das perspectivas dos demais sujeitos relacionados a ela. Isso porque, em grande medida, é do contexto da sociedade mais ampla que parte a reação que caracteriza a prostituição como desvio. A importância da análise das narrativas trazidas pelos grupos acima mencionados acerca da prostituição na W3 norte reside, portanto, na possibilidade de delinear, ao menos em parte, o mecanismo dessa reação social. Mas a sua importância vai além disso. Os grupos indicados lidam diretamente com a prostituição no contexto de suas atividades profissionais, e, portanto, a análise de suas narrativas possibilitará um melhor delineamento da dinâmica da prostituição na W3 norte, seja pela confirmação ou contradição daquilo já observado nos capítulos anteriores seja pelo complemento de aspectos ainda não tratados.

Para tanto, foram realizadas entrevistas com 4 clientes de prostitutas da W3 norte ${ }^{155}$, com 5 policiais militares que atuam no policiamento ostensivo na Asa Norte há mais de 5

\footnotetext{
${ }^{155}$ Para chegar aos clientes entrevistados, acionei minha rede de contatos entre os colegas do sexo masculino da PCDF, os quais, por sua vez, indicavam-me amigos que usavam os serviços das prostitutas da W3 norte. Depois da primeira entrevista, cada entrevistado me indicava outro colega. Utilizei assim a técnica da "snowball sampling" ("Bola de Neve"). "Essa técnica é uma forma de amostra não probabilística utilizada em pesquisas sociais onde os participantes iniciais de um estudo indicam novos participantes que por sua vez indicam novos participantes e assim sucessivamente, até que seja alcançado o objetivo
} 
anos, e também com 4 policiais civis (2 agentes de investigação da $2^{\mathrm{a}} \mathrm{DP}$, que abrange a Asa Norte, e 02 delegadas da DEAM). Além disso, durante as entrevistas com os policiais civis, consegui contato com o proprietário do site de anúncios de garotas de programa, o qual concordou também em participar da pesquisa.

Da mesma forma que no capítulo anterior, o método adotado para realização das entrevistas com esses sujeitos da ação social (os quais chamei de "os outros", em oposição a elas, as prostitutas) foi o da entrevista reflexiva, que considera horizontal e interativa a relação entre o entrevistador e o entrevistado. Devo admitir que, ao contrário das incertezas que tive antes de conversar com as prostitutas, nas entrevistas com os policiais militares e civis, sentime bem mais à vontade, mesmo porque eu também sou policial e também trabalhei na área da Asa Norte durante 2 anos. Contudo, conforme esclareci no início da dissertação, minha condição de policial e de pesquisadora acadêmica, em todo momento, acionava ainda mais a vigilância epistemológica durante a coleta, interpretação e elaboração escrita dos dados.

Algumas entrevistas foram feitas pessoalmente, no caso dos policiais civis, de dois policiais militares e de três clientes, outras por telefone ou por videoconferência para maior comodidade dos entrevistados. A técnica adotada foi a entrevista semiestruturada, com um roteiro previamente determinado, mas que permite a flexibilidade no decorrer da conversa, que se encontram no Anexo 3. A exceção do proprietário do site de anúncios de garotas de programa no Distrito Federal, o qual permitiu a divulgação de seu nome verdadeiro, e também das duas delegadas da DEAM, a identidade dos demais entrevistados foi preservada, sendo alterados seus nomes por fictícios, tanto por questões pessoais quanto profissionais.

Seguem-se os resultados das entrevistas agrupados em dois itens: 1) o mercado da prostituição, no qual serão abordadas as narrativas dos consumidores (clientes) e também de um administrador de site de anúncios de acompanhantes; e 2) as narrativas dos policiais militares e civis que trabalham na área da W3 norte. Para facilitar a análise, as entrevistas foram estruturadas em assuntos: a dinâmica da prostituição, a subjetividade das prostitutas e, finalmente, as vulnerabilidades da atividade, seguindo a mesma lógica estabelecido no Capítulo 3, referente às narrativas das próprias prostitutas.

proposto (o "ponto de saturação"). O "ponto de saturação" é atingido quando os novos entrevistados passam a repetir os conteúdos já obtidos em entrevistas anteriores, sem acrescentar novas informações relevantes à pesquisa. Portanto, a snowball ("Bola de Neve") é uma técnica de amostragem que utiliza cadeias de referência, uma espécie de rede." (BALDIN e MUNHOZ, 2011, p. 332). 


\section{O mercado de prostituição na W3 norte}

A prostituição pode significar algo diferente na vida de cada um dos seus usuários. Para alguns, é a principal forma de manter relações sexuais, seja por deficiência física ou falta de habilidade social. Para outros, é a oportunidade de realizar fantasias eróticas ou de ter experiências sexuais que não teriam em um relacionamento amoroso, seja em razão de as prostitutas serem sexualmente "mais soltas", como disse um dos clientes, ou por permitirem que estes realizem as suas mais bizarras fantasias sexuais sob o véu no anonimato.

Dessa forma, o grupo dos usuários dos serviços de prostituição parece ser bastante heterogêneo. Segundo os policiais militares entrevistados, "na avenida W3 norte, há todo tipo de cliente, adolescentes, idosos, recrutas do Exército (principalmente entre os dias 30 e 3 de cada mês, época do recebimento do soldo), carros luxuosos de embaixadas, deficientes físicos". Apesar da diversidade do mercado consumidor da prostituição, seria possível, conforme a representação de um dos entrevistados, classificá-los em três grupos distintos. Para Lucas, há os clientes eventuais, os profissionais e os "Don Juan"156. Interessante que a percepção classificatória de Lucas, ao longo das outras entrevistas a clientes e policiais, e também em conjunto com as demais observações realizadas do espaço, pareceu descrever bem as diferentes posturas dos usuários em relação à prostituição, em especial os três clientes que mencionarei mais detidamente no presente trabalho: João, Marcos e o próprio Lucas.

O cliente eventual é aquele que faz programas apenas de vez em quando, para "dar uma variada", nas próprias palavras de Lucas, ou ainda por curiosidade. A principal característica desse usuário é que o consumo do serviço de prostituição não é um elemento importante em sua vida. Entre os entrevistados, Lucas é um exemplo desse grupo.

Diversamente, o cliente profissional é aquele que "gosta mesmo de prostituta", e investe uma grande quantidade de tempo e dinheiro nessa atividade, de modo que em que ela é uma parte muito importante de sua rotina. É o caso do entrevistado Marcos.

Por fim, o cliente "Don Juan" é, na realidade, uma espécie de cliente profissional, mas que, além das demais características indicadas, costuma se apaixonar pelas prostitutas. $\mathrm{O}$ entrevistado João pertence a essa categoria.

\footnotetext{
${ }^{156}$ Don Juan é um personagem arquetípico da literatura espanhola, criado pelo autor Tirso de Molina, pseudônimo de Fray Gabriel Téllez (1579-1648), na obra "El burlador de Sevilla y convidado de Piedra", na qual Don Juan Tenorio, o personagem principal seduz várias jovens fazendo se passar pelos seus noivos e as abandona. Desde então, a história tornouse um clássico nas mãos de Molière, que escreveu a comédia "Don Juan", de Mozart, na ópera "Don Giovanni”, de Pushikin, com a peça "O convidado de pedra", de Alexandre Dumas, com a peça "Don Juan de Maraña", de Charles Baudelaire, com o poema "Don Juan no inferno" e, mais recentemente, no cinema com o filme "Don Juan de Marco", de 1995, estrelado por Johnny Depp e Marlon Brando. O personagem então assumiu a representação do jovem conquistador e galanteador.
} 
Naturalmente, a divisão em categorias entendidas aqui como tipos ideais é apenas um recurso metodológico para facilitar a análise das entrevistas. Nada impede que um cliente pertença a duas ou a nenhuma delas.

Feitas essas considerações, passa-se a examinar as representações sociais desses clientes acerca da atividade de prostituição em si, seguindo a ordem de assuntos acima indicada.

Um dos primeiros questionamentos que fiz aos clientes se referiu ao porquê de eles buscarem a atividade de prostituição.

Para João, a prostituta faz muita coisa que a menina "de família" não faz, embora não costume beijar na boca. Ele contou que atualmente não procura tanto os serviços das prostitutas, porque está casado com uma mulher que não tem esse problema, pois ela gosta de fazer tudo o que as prostitutas fazem. Além disso, segundo ele, sair com uma prostituta representa um programa muito mais econômico do que sair com uma "gatinha". Com a prostituta, explicou João, o homem paga e tem garantia de que vai manter a relação sexual. Já com a "gatinha", se o objetivo é apenas sexual, até "rolar", demanda várias "saídas", "com o homem pagando a conta de restaurantes e baladas", porque dificilmente a "gatinha" aceita dividir as despesas do encontro e ainda sim, com a "gatinha", não há garantia de que a relação sexual vai acontecer.

João acrescentou que com a prostituição é possível manter relações sexuais com mulheres muito mais bonitas do que ele conseguiria por meio dos mecanismos usuais de cortejo e conquista. Essa questão da beleza das prostitutas tem relevância na representação de João da atividade de prostituição. Ele, que já foi um frequente cliente de prostitutas, contou que, no passado, usava estimulantes sexuais nos seus encontros com prostitutas, não só por conta de ter que usar camisinha, o que, segundo ele, desestimulava a sua libido, mas porque as garotas de programa muito bonitas o intimidavam.

De certa forma, parece que João associa a prostituição como um mecanismo simples para resolver suas necessidades, seus desejos, como se fosse uma mercadoria. Por meio desse serviço, ele disse que pode ter acesso a relações sexuais sem o esforço do cortejo, do convencimento, com um padrão maior de qualidade, seja relacionado à beleza física, seja quanto ao desempenho sexual, e ainda de forma mais econômica, se comparado à tradicional paquera, quando a finalidade desta é apenas sexual.

Dos clientes entrevistados, João, a quem classifico como um "Don Juan", foi um dos que demostrou maior expertise sobre a prostituição, mesmo porque ele já chegou a manter um relacionamento amoroso com uma prostituta por cerca de 3 anos. Nessa oportunidade, ele pode conviver com os bastidores da prostituição, conhecendo também o ciclo social de Flora, 
a prostituta que se tornou sua companheira durante esse período, sem abandonar a atividade de prostituição.

Por sua vez, outro motivo indicado, nas entrevistas, para a busca da atividade de prostituição, foi a necessidade de variabilidade, a curiosidade ou ainda a supressão de um desejo eventual, diante da impossibilidade temporária de manter relações sexuais com a parceira fixa. Esse foi o caso de Lucas, apesar de ter dito que não gosta muito de utilizar os serviços das prostituas, porque julga a relação sexual com elas muito artificial e mecânica, sem o prazer da conquista. Ele contou que já fez, por vezes, uso do serviço para atender aquilo que considera uma "necessidade", como a ausência de relações sexuais com a atual namorada ou companheira por longo período de tempo, em razão, por exemplo, de gravidez ou da amamentação de filho. Na sua opinião, outro fator que atrai os homens para as prostitutas é a confiança no anonimato, pois, por causa dele, eles se abrem, e pedem as "bizarrices todas", apesar de ele não me detalhar quais seriam essas "bizarrices".

Lourival, outro entrevistado, me disse que já procurou os serviços de prostituição para, aproveitando-se também do véu do anonimato, avaliar seu desempenho sexual, mas não ficou satisfeito porque não sentiu sinceridade na opinião da prostituta que o elogiara bastante.

A questão do anonimato é um elemento central na fala de muitos desses clientes. Ou seja, para eles, mostra-se importante não serem reconhecidos publicamente como usuários do serviço de prostituição, pois consideram que há um estigma associado a essa condição. Todavia, em particular, é comum a troca, entre os homens em seus grupos privados de amigos, de histórias das suas aventuras no mundo da prostituição. Interessante notar, nesse comportamento, não só a relação com o estigma da própria prostituição, mas também com aquele ainda presente nas eventuais atividades sexuais "extraconjugais", em uma sociedade onde se predomina o paradigma heteronormativo e monogâmico, conforme já mencionado, no capítulo introdutório, ao tratar do dispositivo de sexualidade proposto por Foucault.

$\mathrm{O}$ anonimato mostra-se útil ainda para encobrir o gosto dos clientes por fantasias "sexuais" tidas como bizarras, ou seja, representadas socialmente como desvios. É útil ainda, como se viu no caso de Lourival, para a verificação do seu desempenho sexual, coisa que não pode fazer de forma pública, diante da obrigação de virilidade e desempenho sexual imposta aos homens na distribuição social dos papéis sexuais.

As fantasias tidas como bizarras ou desviantes referem-se desde práticas de masoquismo, sadomasoquismo, e inversões, bem como a experiências homossexuais, que, em certa medida estão caracterizadas como desviantes do padrão da normalidade hetoronomativa e monogâmica. A alusão ao anonimato e a impessoalidade da prostituição garantem o 
"segredo dos clientes", como bem relatou Mônica, no Capítulo 3, o que é importante, por exemplo, para clientes homossexuais ou mesmo bissexuais, ou ainda para a prática do “fisting”. Afinal, como disse a prostituta $\mathrm{Su}$, o seu trabalho é vender fantasias.

Os segredos ligados à sexualidade rementem também à metáfora do "armário", um local escondido e privado, ideal para garantir a discrição dos desejos mais íntimos. Essa categoria também pode ser associada, de certa forma à prostituição de rua, que busca os espaços mais discretos e escuros para a realização dos programas, a fim de garantir o segredo dos clientes e também, em alguns casos, das próprias prostitutas.

$\mathrm{O}$ armário seria uma metáfora arquitetônica que extravasaria do corpo que se declara para os espaços circundantes e teria repercussões na escala urbana, como sugerido pelo geógrafo Michael P. Brown em seu livro "Closet Space: geographies of metaphor from the body to the globe". Para Brown, haveria reproduções do armário em escala urbana, reproduções que seriam táticas e estratégias de poderes heteronormativos sobre a cidade, como objetivo de minimizar a visibilidade dos corpos dissidentes nas urbes. Sugere também que o armário na escala urbana seria produto material da heteronormatividade intencionando comoditizar o desejo homossexual a fim de lucrar com este, inserindo-o em relações capitalista. (TEIXEIRA, 2013, p. 56).

Além da discrição e do anonimato, outro fator que incentiva a busca da atividade de prostituição é a impessoalidade e objetificação da relação sexual, de forma a considerá-la como um produto, ideia várias vezes ressaltada na entrevista de Marcos.

Para ele, a razão para procurar as prostitutas é a falta de compromisso, a falta de cobrança, a falta de necessidade de dar atenção e de envolvimento subjetivo. "Só fíca com o bom do relacionamento, não há cobranças, só o pagamento em dinheiro".

Marcos relatou que utiliza o serviço de prostituição há quase 20 anos e não a considera um vício, mas um "brinquedo legal”, que, quando vê um, precisa comprar.

Não é só questão de fazer um sexo diferente. Depois que casa, por mais que você ensine sua mulher a fazer as coisas, não é a mesma coisa. Porque com a prostituta não há a afetividade. Com a mulher há uma relação afetiva. Por mais que haja um tapa, uma amarração, não é a mesma coisa que fosse com uma desconhecida. Tem um quê de fetiche de poder, pois a mulher fica à sua disposição. O cliente está no poder daquele relacionamento. É por isso que ele paga. A prostituição é uma relação de poder, ou do cliente ou da prostituta (Marcos, cliente).

Atualmente, Marcos disse que não procura mais prostitutas de rua, mas ao longo dos seus vinte anos de experiência, ele conhece muitos tipos de prostituição. 
Prosseguindo a sua fala, Marcos relata que, com o tempo, observa-se um padrão no comportamento das prostitutas. Ele as divide em: "puta carente", "puta profissional" e "puta que é profissional e depois fica afetiva" e "é preciso saber agir com cada uma". Marcos considera que, no fundo, "toda puta é carente". Até as "chiques", que dizem que querem arrancar dinheiro dos clientes "trouxas", são carentes, e elas dizem isso para esconder as suas “carências". Segundo Marcos, ele "já pegou o jeito do negócio e ele lê o comportamento das meninas", por isso, na classificação de Lucas, Marcos recebe o rótulo de cliente profissional.

"Você sabendo acertar esse ponto do dinheiro, e lê-las, elas ficam na sua". Para ele, a relação central entre a prostituta e o cliente é o binômio manipulação e poder. O domínio é um elemento fundamental da relação com as prostitutas. Por isso, não dá certo os casamentos de clientes com prostitutas: quem consegue a hegemonia acaba perdendo o interesse na relação. "As prostitutas têm esse sonho de que vão enriquecer, que vai conquistar o poderoso, que vai conseguir tal o qual coisa. E tem casos de sucesso".

Nota-se que a representação de Marcos sobre a prostituição reforça o imaginário cristalizado e objetivado, traduzido nas narrativas morais e sociológicas, expostas na introdução do trabalho. Nesse contexto, a atividade de prostituição, tradicionalmente vinculada à figura feminina, estaria diretamente relacionada à posição de submissão do poder do homem sobre a mulher, no contexto da sociedade patriarcal.

Contudo, a manipulação e o poder mencionados por Marcos também podem se dar por parte da prostituta em relação ao cliente. Como visto, nas falas de Lourival, de João e do próprio Marcos, muitos homens buscam a prostituição para realizar fantasias privadas que não poderiam ser concretizadas com as parceiras tradicionais ou mesmo buscando uma avaliação ou aprimoramento de seu próprio desempenho sexual. E é a prostituta que guarda a chave para essas possibilidades.

Assim, nesse contexto, o programa assume uma rede de trocas de expectativas, como se a sexualidade assumisse um dispositivo de poder que põe em pleno funcionamento "uma rede de afetos, que, ao interagirem, produzem novos modos de subjetivação; são traços de outros corpos em nosso corpo, um amor desorientado que escorre na multiplicidade de linhas do tempo constituindo incessantemente um lugar sem lugar. É uma dinâmica marcada por um estado de fragilidade do corpo, neste caso o corpo frágil é uma condição de paradoxo, que se inscrevem atos de profanação nesse borrar incessante dos corpos e dos sexos na zona de promiscuidade". (BORTOLANZA, 2014, p. 271)

Esse paradoxo da fragilidade e da fortaleza, da vitimização e da "femme fatale", está presente nas narrativas da maioria dos clientes e também das garotas de programa, apesar de 
cada entrevistado possuir diferentes graus de capacidade para articula-los em forma de narrativa, na medida de seus repertórios pessoais. Ademais, esse entrelaçamento paradoxal, entre o fraco e o forte, a depender da situação, aliada às ideias do anonimato e também da impessoalidade, enseja a vivência do que Bortolanza chamou de uma nova micropolítica sexual, distante do paradigma heteronormativo monogâmico:

Uma micropolítica sexual que não está centrada na diferenciação dos sexos ou nos modelos de representação social da família, cujos modos de expressão são outros em relação aqueles conjugados no jogo da representação édipo-conjugalidade-filiaçãohereditariedade; sexos que entram em agenciamentos por contágio, simbioses, combinações promíscuas. Agenciamentos que remexem nos nós mais profundos ou subcutâneos dos sexos, e que mexem com as instituições como a família e o Estado - para além dos termos da correspondência do 'parecer', 'ser', 'equivaler', 'produzir' - um trottoir nos corredores da sexualidade que atraem o pensamento para este lugar sem lugar, para as zonas de promiscuidade (BORTOLANZA, 2014, p. 271).

Esse micropoder, limitado a quatro paredes, na maioria dos casos não é objeto de discussão ampla entre o cliente a prostituta, como contou Marcos, mas apenas de um sentir. E, segundo ele, é o que o atrai diretamente à prostituição, a sensação de poder, que, para ele, na grande maioria dos casos, assume a posição de dominante, mas também pode admitir ser o dominado pela mulher.

Os deslindes do prazer e do poder por meio da exploração dessas "zonas de promiscuidades", a que se referiu Bortolanza, constituíram e ainda constituem interditos do dispositivo de sexualidade, centrado na heteronormatividade e na monogamia. ${ }^{157}$ Assim, no contexto do corpo como um processo político, cuja significação é dinâmica, como defende

${ }^{157}$ Como bem lembrou R. Miskolci, durante muito tempo o estudo das sexualidades concentrou-se apenas nas funções reprodutivas e classificava tudo que era diferente em anomalias, passíveis de objetivação e cristalização pelas representações sociais da Medicina, Direito e Moral, como desvios e perversões, o que interditou a discussão desses temas de forma aberta. Com a psicanálise e os questionamentos de Sigmund Freud, começou-se a discussão de temas como desejos sexuais e homossexualismo de uma perspectiva descritiva e não valorativa. "A sexologia ganhou força por meio da classificação e descrição de todos os desvios das funções reprodutivas. Inicialmente, suas relações com a psiquiatria institucionalizada, em particular com a vertente criminológica, tornaram-na um saber destinado ao poder, provedor de justificativas para a perseguição, controle e até aprisionamento dos que considerava perversos. Essa versão sexista e homofóbica da sexologia é corporificada na obra de Richard Von Krafft-Ebing, mas precisa ser confrontada com outra, voltada para o reconhecimento da variabilidade sexual e sua despatologização, vertente iniciada com os estudos de Magnus Hirschfeld na Alemanha e desenvolvida também por Havelock Ellis na Inglaterra. No final da década de 1940, chegaram a público as pesquisas de Alfred Kinsey sobre a grande variedade de práticas sexuais, constatação tão liberal quanto impregnada de justificativas essencializantes. Em contraste com a sexologia de seu tempo, Sigmund Freud criou a Psicanálise com uma proposta de compreensão universalizante da sexualidade baseada na mobilidade multiforme do desejo sexual e na bissexualidade como potencial em qualquer pessoa. Este argumento antiminorizante, no entanto, só se tornou palatável ao ser articulado a uma teoria que via no interesse por indivíduos do mesmo sexo apenas uma fase no caminho para a vida adulta, compreendida como sinônimo de heterossexualidade. A articulação entre universalismo antiminorizante com uma teoria desenvolvimentista camuflou seu heterossexismo e masculinismo. De qualquer forma, Freud, ao contrário dos sexólogos, não se preocupava em classificar, caracterizar nem julgar "pervertidos" ou "invertidos", pois seu foco era o custo psíquico (neurose) cobrado pela "normalidade sexual"." (MISKOLCI, 2009, p. 165-166). 
Grosz (2000, p.84), a prostituição, com suas características da impessoalidade e anonimato, proporciona novas experiências para ressignificações tanto para o corpo em si quanto também para o próprio dispositivo de sexualidade. “As prostitutas ao encarnarem a fantasia no corpo dão um novo estatuto político para a zona de promiscuidade da sexualidade, porque destituem a interdição e a censura no potencial de anulação do corpo prazeroso na abertura e força de efetuação das fantasias. É um espaço em que é permitido fantasiar realizando. Uma atualização no corpo das potências virtuais dos sexos” (BORTOLANZA, 2014, p. 281).

Reforçando essa ideia de micropoder na relação entre prostituta e cliente, Marcos relatou que, para ele, não apenas a necessidade financeira leva a mulher à prostituição, porque há outras formas de ganhar dinheiro. A questão central seria o poder: "Umas falam que entraram para a prostituição para cuidar de filho ou para pagar a faculdade. Outra parte vai falar que quer pagar a baladinha, que já dá de graça, e que não tem problema de cobrar. A diferença de um grupo e outro acaba sendo a classe social. Essas são as desculpas iniciais, mas depois elas permanecem na prostituição porque gostam do poder. Daí não saem mais".

Contudo, João e Marcos relatam histórias em que a atividade de prostituição é apenas um impulso para o crescimento econômico daquelas prostitutas que têm os objetivos muito claros, o que também foi confirmado nas falas dos policiais, como será visto a seguir. Segundo Marcos, essas prostitutas sim são as efetivamente profissionais, e enxergam no cliente um simples instrumento para alcançar os objetivos dela. "Vou dar para o cara, porque quero a grana dele", ressaltou Marcos como sendo a marca do pensamento delas, e disse que é essa a mulher que consegue sair da prostituição. Geralmente, ela entra na faculdade, inicia a atividade empreendedora, porque, segundo ele, elas encontram certa dificuldade para desenvolver uma carreira no mercado de trabalho formal, por temerem encontrar com algum cliente. Todavia, segundo o próprio Marcos, essa situação estaria mudando, pois, a cada dia, essas mulheres não vêm mais problemas em serem identificadas como prostitutas, de forma que se alguém as reconhece na rua, elas não se importam tanto quanto antes. Porém, não tomam a iniciativa de se identificar dessa forma, e, apesar das mudanças, ele ressalta que a atividade não pode ainda ser considerada como "normal", livre de preconceitos no meio social. Tanto é assim que, no Capítulo 3, observamos que a maioria das prostitutas mente para sua família e amigos sobre sua atividade profissional.

Outro aspecto interessante é entender quais são as estratégias que os clientes encontram para selecionar as prostitutas para os programas. No contexto da W3 norte, João, Lucas e Mateus, por exemplo, disseram que, às vezes, gastam muita gasolina para escolher a prostituta, ao atravessar de uma ponta a outra da avenida W3 norte (cerca de 12 quilômetros). 
Contudo, além da forma tradicional de ir "às esquinas", ou no caso de Brasília, percorrer as quadras comerciais ou vitrines da W3 norte, há também a possibilidade de encontrar as prostitutas em anúncios de sites de acompanhantes, mais frequentemente, ou ainda no setor dos classificados nos jornais impressos, cada vez mais escassos. Parte das prostitutas que anunciam seus serviços nos sites de acompanhantes em Brasília também vão para "pista" na W3 norte, e prestam seus serviços nas quitinetes alugadas, conforme já exposto no Capítulo 3.

João disse que costuma utilizar o fórum do site "Gpguia" $" 158$. Nesse site, há comentários de clientes sobre as prostitutas, avaliando seus serviços sobre vários aspectos, como beleza, educação, tipos e qualidade dos serviços sexuais, no que é denominado, nessa comunidade virtual, de "test drives". No entanto, ressaltou que, hoje em dia, desconfia dessas avaliações, pois muitos cafetões inserem comentários no fórum, para promover as prostitutas com quem trabalham, impressão essa compartilhada por Mateus. Ainda segundo João, acontece também de ter confusão, porque a mulher não corresponde ao que está no site, por causa do "photoshop"159. Existem ainda outros sites, como o "socinquenta.com"160, que possibilita selecionar prostitutas por região, permitindo à pessoa dar "pequenas" escapadas próximas de casa.

A existência desses sites já tinha sido mencionada nas entrevistas das prostitutas, expostas no Capítulo 3. Para elas, é mais uma forma de captar clientes, embora, como se viu, nem todas tenham tido sucesso nesse novo veículo de comunicação, o que talvez tenha a ver com o perfil da prostituição da W3 norte.

Nesse ponto, mostra-se relevante a experiência de João como usuário do serviço de prostitutas tanto de sites quanto da W3 norte. Ele diz que prefere as prostitutas do site, e que a diferença entre os dois está na qualidade das prostitutas e no ambiente onde ocorrem os programas. Para ele, na W3 norte, as mulheres são mais feias, e é difícil achar uma "mais ou menos". O ambiente da região é pesado, sujo, escuro e perigoso. "Tem muito usuário de crack. É melhor pagar mais caro no site”. Mas ele utiliza os serviços das prostitutas da W3 norte, às vezes, por conta da oportunidade. Por exemplo, "a pessoa está saindo de uma "night"

\footnotetext{
${ }^{158}$ O GP guia (garota de programa guia) é um fórum e também espaço para anúncios de serviços de prostituição feminina, masculina ou travesti, no Distrito Federal. Nele, os usuários comentam e avaliam os programas e seus profissionais. Segundo a informação dos entrevistados, o site, que antes tinha maior confiabilidade em relação aos depoimentos, vem perdendo a credibilidade em razão de muitos "cafetões" ou de os próprios profissionais do sexo fazerem comentários autopromocionais. O acesso ao site é pelo link: http://www.gpguia.net/. Acesso em 20/10/2016.

${ }^{159}$ Photoshop é um programa de edição de imagens que, segundo o entrevistado João, é muito utilizado para melhorar a aparência física das prostitutas em anúncios sobre seus serviços sexuais.

${ }^{160}$ Diferente do GP guia, os sites "Só cinquenta" e "Capital sex" não constituem fórum de interação entre os usuários da prostituição, mas apenas um espaço para a exposição do portifólio de cada profissional do sexo na região do Distrito Federal. Nesses sites, há seções para a prostituição masculina, feminina e também de travestis. http://socinquenta.com/ e http://www.capitalsexy.com.br/ . Abordarei melhor o funcionamento desses sites, a seguir, na entrevista ao proprietário do "Capital Sex". Acesso em 20/10/2016.
} 
ali por perto, e passa por lá e faz um programa. É como um delivery. Nunca foi em um ambiente bonito".

Lucas concorda com essa caracterização da prostituição na W3 norte. Para ele também, a diferença entre as prostitutas da W3 norte e as do site está na qualidade e no ambiente. "Na W3 norte, tem umas mulheres muito caídas. Os ambientes são muito "muquifos". Lá tem muito "peba""161. Contudo, há quem goste dessas prostitutas mais caídas", defendeu.

Já Marcos só buscou por uma vez o serviço de prostituição na W3 norte. Para ele, prostituta de rua não tem "qualidade, porque há um grande risco de pegar uma louca, de fazer um escândalo, de ela te agredir, de ela te roubar. Na rua, as mulheres são mais desesperadas, pois qualquer uma pode ir para a rua rodar bolsinha. Quando você contrata uma prostituta em uma casa especializada, você pode reclamar, porque a casa de prostituição tem um nome a zelar, e elas são selecionadas".

Nesse contexto, pode-se lembrar da interessante discussão sociológica sobre a categoria rua, trazida por Caruso, ao recuperar as ideias de Damatta no sentido de que a rua é um lugar insólito, um poço de inseguranças, ao contrário da casa, que traz aconchego e certezas.

\begin{abstract}
Ora, dentro de uma perspectiva abordada pela antropologia urbana brasileira, a oposição casa e rua, analisada numa perspectiva Damattiana, é reveladora. Neste sentido, a categoria rua "indica basicamente o mundo com seus imprevistos, acidentes e paixões, ao passo que a casa remete ao universo controlado, onde as coisas estão nos seus devidos lugares". (DAMATTA, 1997:90). Se por um lado, a rua traz em si a ideia de movimento e ação, a casa implica em harmonia e calma. Por um lado, têm-se as incertezas das ruas, os inúmeros códigos a serem decifrados; por outro, a previsibilidade da casa, que suscita a certeza de que tudo funciona harmonicamente (CARUSO, 2009, 151).
\end{abstract}

Ainda sobre a dinâmica da prostituição, João considera que a maior parte do movimento na W3 norte ocorre nos dias da semana. Acredita que isso ocorre porque, para os clientes, é mais fácil dar "pequenas escapadas" durante a semana, e também porque muitas delas tiram os fins de semana para ficar com as famílias. Lucas confirma essa percepção, e considera que isso acontece, porque, durante a semana, é mais fácil "dar o perdido".

Nesse contexto, João relatou uma história que ilustra bem a dinâmica da prostituição na W3 norte. Em um dos programas que realizou na W3 Norte, ele estava passando pela região,

\footnotetext{
161 "Peba" é uma categoria nativa comumente utilizada pelos policiais militares do Distrito Federal, como muito bem retratou Gilvan Gomes da Silva, em sua dissertação de mestrado, no departamento de sociologia da UnB, intitulada "A construção do suspeito na lógica da polícia militar do DF". Segundo ele, "o tipo ideal do indivíduo suspeito, o peba, é a figura de um homem, pobre, jovem, com tatuagem/brincos e negro que traja roupas folgadas (bermudão e camisa com número nas costas e, geralmente, do grupo musical RACIONAIS MC's) com boné. Geralmente, essas vestes são usadas por pessoas que se identificam com o movimento Hip Hop." (SILVA, 2009, p. 98).
} 
quando observou uma prostituta que considerou bonita, algo anormal, segundo ele, naquela região. Aproximou-se, combinou o programa, e acompanhou a prostituta até o seu “ambiente", que ficava nas 700, por trás da W3 norte. Chegando lá, o apartamento era divido, por um biombo, em duas partes, cada uma delas utilizada em um programa. Os dois biombos estavam ocupados, e assim teve que esperar na "sala de estar". Estava conversando com a prostituta, quando chegou outro casal, que também sentou para esperar a liberação dos biombos. Em seguida, chegou um terceiro casal. Logo, os três casais estavam ali conversando, enquanto esperavam a sua vez no biombo. Finalmente, chegou a sua vez, e ele entrou no pequeno biombo e realizou o programa.

Em contraposição, segundo os entrevistados, os programas em que os clientes agendam por meio dos sites de acompanhantes na internet são normalmente realizados em apartamentos e quitinetes limpas e bem organizadas em áreas residenciais. E, foi nesse contexto que João desenvolveu relações mais estreitas com prostitutas. Apesar de esse trabalho tratar especificamente da prostituição na W3 norte, e não daquela realizadas em outras regiões da cidade, essas histórias trazidas por João são importantes, porque auxiliam na compreensão da dinâmica da atividade em seus aspectos mais íntimos, que, por sua dimensão humana, decerto estão presentes também na vida das prostitutas da W3 norte.

Flora, natural de uma pequena cidade do Estado de Goiás ${ }^{162}$, foi a primeira prostituta com quem João teve um relacionamento mais sério. Ele a conheceu em seu trabalho, em um banco, a qual não lhe disse, inicialmente, que era prostituta. Contudo, segundo João, desde o início ele já sabia, porque ele era um cliente assíduo da prostituição. João se orgulhava ao dizer que Flora nunca lhe cobrara pelo programa, porque, segundo ele, costumava “conquistar" as prostitutas, motivo pelo qual o classifico como o cliente "Don Juan". João contou que Flora tinha um bom "ambiente" com dois quartos, localizado no Sudoeste, que dividia com outra prostituta. Aquilo impressionou João, que era muito novo na época com aproximadamente 22 anos. Ela morava e atendia no local. Passaram a se encontrar, e a se relacionar, e, com o tempo, passou a dormir na casa dela. Com isso, passou a viver no mundo da prostituição, durante os três anos de relacionamento. $\mathrm{O}$ apartamento era frequentado por muitas prostitutas, até porque, Flora passou a ter um site de "acompanhantes", um dos

\footnotetext{
${ }^{162}$ Segundo João, Flora tinha o segundo grau e tinha filho, cujo pai a agrediu e colocou fogo em sua casa. Depois disso, ela se mudou para Brasília, deixando o filho aos cuidados da mãe, para quem mandava dinheiro, já que o pai da criança não contribuía com seu sustento. Flora veio de uma cidade do interior do Estado de Goiás que, de acordo com João, tinha uma cultura da prostituição. Por exemplo, ela tinha 4 amigas da sua cidade natal que tinham ido para Brasília se prostituir, e uma delas, inclusive, tinha ido, por um tempo, trabalhar como prostituta na Itália. Nesse ponto, mostra-se útil para a compreensão da entrada ao menos de Flora na prostituição a referência à teoria da associação diferencial, mencionada no capítulo introdutório, de acordo com a qual todo comportamento, inclusive o desviante, é aprendido pela interação social com pessoas que já o possuam.
} 
primeiros do DF, que tirava fotos das prostitutas e as colocava no ar. Como dito, João achou aquela situação muito excitante, e "tudo era só putaria", narrou, o que lhe dava, segundo ele uma sensação de poder e aventura. "Sair da casa de sua mãe e de uma vida comum da classe média brasiliense, e passar a dormir muitas noites no quarto de sua namorada prostituta". Mas depois começou a sentir ciúmes dela, mas, como não tinha dinheiro para tirá-la "da vida", não tinha o que fazer. Flora ganhava mais do que João, mas não tinha nada, gastava tudo, inclusive ajudando a mãe na sua cidade natal.

A partir de sua experiência, João relatou que considera o mundo da prostituição um mundo pesado, com muita gente diferente, com várias tendências, algumas delas agressivas. Às vezes, ele entrava no quarto logo depois de ela ter atendido um cliente, ou ficava esperando ela terminar o programa, e aquilo lhe deixava incomodado. Ele contou que até conseguia ver que aquele era o trabalho dela, mas era muito difícil em termos emocionais. Quando ficava irritado com aquela situação, falava para ela que aquele era um "dinheiro fácil", e de fato elas ganhavam muito dinheiro. Flora respondia que não era "fácil", pois: "estou mostrando uma coisa aqui, e não estou sentindo isso, estou mostrando algo que não sou". Uma vez, viu marcas decorrente de um cliente ter jogado Flora do carro em movimento, mas não houve registro de ocorrência. Segundo João, ele nunca a viu usando drogas, mas muitos clientes traziam para usar durante os programas ${ }^{163}$.

Depois de Flora, João teve também um relacionamento, menos intenso e duradouro, com Kelly, uma prostituta que conheceu no fórum do site Gpguia. Procurou ela porque era bem avaliada no site, o seu "ambiente" ficava próximo a sua casa, e, segundo o seu anúncio, fazia "de tudo". Na época, 5 ou 6 anos atrás ${ }^{164}$, o programa custou R $\$ 150,00$. Depois da primeira relação sexual, eles ficaram conversando e desenvolveram um relacionamento após Kelly tê-lo convidado para voltar gratuitamente no dia seguinte. Apesar de estar em um relacionamento sério na época, João disse que buscou Kelly porque sua namorada era muito "travada" e, para ele, "mulher na cama tem que ser puta". João disse que saia com a namorada, depois ia à casa de Kelly de madrugada, transava e ia embora.

Para ele, Kelly era tecnicamente muito competente em razão de suas práticas de pompoarismo. Contudo, às vezes ele a visitava só para conversar, oportunidade em que ele soube muitas histórias da atividade de Kelly, que entrara para a prostituição, em razão do

\footnotetext{
163 João chegou a apresentar Flora para sua mãe, sem contar sobre a sua atividade profissional, bem como visitou a cidade natal da namorada. Por outro lado, nunca a apresentou para seus amigos, até porque eles sabiam que ela era prostituta. No mais, mostrou-se muito ambíguo sobre se, na época, estava ou não disposto a se casar com ela. Apesar de ter sido repetidamente indagado sobre o assunto, não negou e nem confirmou.

${ }^{164}$ Tendo como referência o ano da realização da entrevista, em 2016, João teria conhecido Kelly em 2009 ou 2010.
} 
sustento de seu filho, que morava em Planaltina. Segundo João, Kelly não realizava práticas tidas como bizarras, como zoofilia e chuva negra, contudo, ela sabia e indicava aos clientes suas colegas que realizam esses tipos de fantasias.

Nosso "Don Juan" sempre gostou muito de conversar com as prostitutas, e, por isso, muitas vezes, acabava por conseguir fazer programas de graça com elas, que se sentiam valorizadas por ele. Muitas delas lhe relatavam que gostavam de passar tempo com ele, porque era muito ruim ficar o dia inteiro dentro de um quarto, mantendo relações sexuais com estranhos. Afinal, "elas também precisam se divertir e têm suas necessidades sociais", assegurou João". Depois dos passeios, mantinham relações sexuais. João contou que uma dessas, saiu da prostituição, e se casou com o funcionário de uma estatal importante.

João considera que nem todas as prostitutas fazem programa por estratégia de sobrevivência e para fugir da miséria. Ele contou que conheceu uma filha de um servidor público bem remunerado, que fazia programa para pagar por "seus luxos" e para suas festas, e não por necessidade de sobrevivência, pois vivia com os pais, que pagavam pela sua educação. Conheceu uma ainda que era professora, e se prostituía para terminar a faculdade. Já para o cliente Mateus, se a mulher não precisa, e ainda assim se prostitui, é porque tem um desvio, um claro exemplo de representação social associada à narrativa religiosa e moral apresentada na introdução do trabalho, que considera a prostituição como sendo um defeito físico, moral ou psíquico.

Ainda sobre a dinâmica da prostituição, Arthur Rampazzo ${ }^{165}$, dono de um site de anúncio de acompanhantes ${ }^{166}$, considera que a prostituição é geralmente a última opção das pessoas a fim de solucionar suas necessidades econômicas. Ele exemplificou casos em que mulheres anunciam seus serviços de prostituição no seu site, para pagar faculdade, pósgraduação, o enterro do pai, ou ainda os medicamentos de familiares em situação de doença. Em suma, segundo ele, a maioria de seus clientes submete-se à prostituição por situação de desespero financeiro. Contudo, ele somente aceita publicar os anúncios se a mulher já tem certa experiência na prostituição e tem certeza de seu intento, mas parte delas pedem para retirar o anúncio assim que alcançam os seus objetivos materiais.

\footnotetext{
${ }^{165} \mathrm{O}$ entrevistado concordou em divulgar sua real identidade.

${ }^{166}$ Arthur Rampazzo é proprietário site de acompanhantes "Capital Sex", que tem como objetivo a divulgação de anúncios de serviços de prostituição de mulheres, homens e travestis. O site teve início em 2007 e foi crescendo gradativamente. Inicialmente, ele não cobrava pelos anúncios das garotas e garotos de programa e ele mesmo editava as fotos para coloca-las nos anúncios. Como a clientela cresceu, ele cobra uma quantia inicial de seus anunciantes e mais uma mensal para manter o anúncio que é elaborado pelos próprios anunciantes. Arthur é casado e contou que, no início teve problemas com sua esposa para que ela aceitasse a atividade do site como profissional. Na verdade, ele mesmo confessou que demorou um tempo para admitir sua atividade como um negócio.
} 
Segundo sua experiência com as prostitutas, Rampazzo acredita que para alguém chegar ao caminho da prostituição, deve haver uma predisposição, porque não é qualquer pessoa que tem a força interior necessária. Arthur reforça que muitas não têm nem a noção do que é a prostituição até o primeiro programa e, quando esse tipo de pessoa lhe procura ele não aceita publicar o anúncio em seu site. Segundo ele, as garotas de programa sem experiência pensam que os clientes são bonitos, com boa aparência e que vão pagar pelo sexo. Contudo, não é bem assim que acontece, o que gera frustração. Assim, em sua opinião, 90\% das garotas de programa são tristes.

Sobre a atividade, ele disse que se trata de um serviço de submissão ao cliente e que as prostitutas são um produto, um objeto para a realização dos desejos dos clientes. Se a menina consegue lidar bem com isso, ela conquista seus objetivos. Contudo, segundo Arthur, há muitas pessoas que entram e não conseguem mais sair, por falta de objetivo, ou inabilidade em gerenciar dinheiro. "Elas até ganham dinheiro, mas não sabem administrá-lo". Assim, disse que ficam na atividade, o tempo passa, a idade chega, e não sabem fazer mais nada. Ele relatou, inclusive, sente-se muito frustrado, quando as garotas de programa pedem para retirar os anúncios do site porque, segundo contam, encontraram um marido, mas logo voltam porque o relacionamento deu errado.

Segundo Rampazzo, a prostituição é um problema moral e não social. Ele mesmo admitiu que, só depois de 6 anos com o site em funcionamento, ele começou a vê-lo como atividade profissional, e a ficar tranquilo com sua consciência em ganhar dinheiro de alguém que se prostitui, alguém que "se deita com outra pessoa por dinheiro", ao ver que ele ajudava suas clientes a realizar seus objetivos materiais e sonhos, compravam lanchas, faziam viagens para o exterior, compravam casas e ajudavam sua família. A partir de então, ele não vê problema algum com sua atividade e afirma que se dedica muito ao empreendimento e que se trata de atividade honesta.

Quanto à vulnerabilidade do trabalho das prostitutas na W3 norte, João, que passou boa parte do tempo convivendo com prostitutas, considera que não há tanto risco de violência urbana e nem por parte dos clientes, porque elas já conhecem aquele lugar. O risco maior é para quem frequenta o lugar. Por vezes, ele conta que teve a impressão de que tinha alguém embaixo da cama, observando/guardando a realização do programa. Tal relato, inclusive não é inédito, e é confirmado pela dinâmica do homicídio da prostituta Raquel e de seu cafetão, José Naciel, já mencionado no Capítulo 2, noticiado amplamente na mídia do Distrito Federal. No curso da investigação desse crime, apurou-se que José Naciel tinha o hábito de se esconder 
em baixo da cama durante os programas, inclusive para garantir a segurança de Raquel em face de clientes mais agressivos ${ }^{167}$.

Contudo, de acordo com Lucas, a relação entre o cafetão e a prostituta nem sempre é tão objetiva. Ele soube de um cafetão que ficou com raiva da prostituta que trabalhava para ele, porque tinha um cliente que queria ver sempre essa prostituta. $\mathrm{O}$ cliente queria fazer programa e "cheirar pó", e o cafetão era também o traficante, mas mesmo assim tinha ciúme.

Marcos contou que as prostitutas de rua buscam um protetor, alguém que possa lhe proteger em caso de o programa "dar merda". Pode ser um policial ou outra pessoa com poder. Diversamente, nas casas de prostituição, o cafetão é a pessoa responsável pela seleção e proteção das prostitutas, bem como pela gestão da contabilidade do estabelecimento.

Sobre a figura do cafetão, Arthur relatou que, a partir de suas vivências, verificou que pode haver duas formas. O primeiro é o explorador, que bate e explora as prostitutas. $\mathrm{O}$ segundo é o "primo"168, aquele que, por uma parcela do valor do programa, protege a garota, esconde-se dentro do armário ou debaixo da cama, arruma o apartamento, e funciona como o 'homem da casa". "Se o cliente não paga, o primo vai lá e faz barraco com o cliente, porque a menina não vai fazer o barraco", contou. Segundo ele, o "primo" não trabalha na rua e ele é mais frequente com as prostitutas em início de carreira, que ainda estão inseguras com a atividade, que atuam em quitinetes, recebem clientes pela internet, e têm medo de alguma violência durante os programas. Segundo Rampazzo, depois que as garotas de programa se sentem mais seguras, "pegam a confiança e seguem no mundo da prostituição na carreira solo". Ainda segundo Arthur, na W3 norte, existe mais a figura do cafetão explorador, que, quando as mulheres precisam efetivamente de proteção, é o primeiro a abandoná-las, além de agredi-las, caso não o produzam o esperado.

Arthur reclamou que a legislação que trata da prostituição é aberta a várias interpretações o que prejudica os envolvidos nessa atividade, pois eles nunca têm a segurança sobre a legalidade de sua atividade, se sua atividade é ou não criminosa. Isso deixa inclusive a prostituta em situação vulnerável, a mercê de pessoas que dizem que vão protegê-las, mas na verdade não o fazem. Essa zona de penumbra também alcança os sites que anunciam

\footnotetext{
167 O homicídio de uma prostituta e de seu guardião ocorrera no dia 23/04/2013, na Asa Norte, e segundo as investigações, José, o guardião "teria o costume de ficar embaixo da cama durante os programas, para evitar qualquer tipo de violência. Há sinais de luta entre o assassino e José, provavelmente porque o autor do crime se assustou ao vê-lo." Para mais informações: http://www.jornaldebrasilia.com.br/cidades/detalhes-sobre-como-a-policia-identificou-o-acusado-de-matar-casal-na-210norte/ Acesso em 23/10/2016.

$\overline{168}$ "Primo" é uma categoria nativa utilizada pelo próprio entrevistado para indicar uma espécie de auxiliar, protetor ou sócio da prostituta. Ao contrário daquele que explora a atividade, auferindo boa parte dos lucros da atividade de prostituição, o primo atua em uma sociedade, garantindo a segurança da garota de programa, morando com ela, prestando serviços domésticos e fazendo companhia, como contou o entrevistado Arthur Rampazzo.
} 
programas, que, a depender do entendimento jurídico, podem ser considerados meios de exploração da atividade de prostituição e, portanto, condutas criminosas.

Tal situação apenas reforça o que foi já descrito tanto na introdução quanto no Capítulo 2 como o "toque de leproso" da prostituta, que contamina tudo que está ao seu redor com uma aura de doença e sujeira, tornando essas atividades estigmatizadas e criminosas.

Segundo João, as prostitutas possuem estratégias próprias para lidar com situações de violência provocadas pelos clientes. A principal seria a forma com a qual elas tratam os clientes, qual seja, de forma seca, objetiva e formal, como se já se colocassem como senhoras da situação. "Tem umas mais grossas e outras mais sutis". Inclusive, a fala de João confirmou as próprias estratégias descritas pelas garotas de programa entrevistadas no Capítulo 3, principalmente a de Mônica que se auto denominou "grossa demais".

Ademais, elas costumam também exigir o valor do programa adiantado, bem como negociar sobre o que vai ser feito e qual será a duração do programa. "Quando dá o tempo acordado, elas ficam mandando, pressionando a pessoa a "gozar", lembrou João, que reclamou dessa prática, contando que já ocorrera de ele terminar o programa sem "gozar"169. Regra geral, o cliente atende, porque não quer confusão, e, muitas vezes, deseja ou precisa do anonimato.

No mais, as prostitutas evitam clientes armados, por medo de não haver pagamento. Até porque, João contou que soube de casos em que os clientes efetivamente apontaram a arma para a prostituta e falaram que não iriam pagar. Há inclusive policiais que dão "carteirada" para não pagar, como relataram os policiais militares, cujas entrevistas serão apresentadas a seguir. Assim como João, Lucas comentou também que as prostitutas não gostam de atender clientes armados. Uma vez, foi fazer programa portando sua arma de fogo, e a prostituta criou muito problema com a presença da arma.

Já do ponto de vista da saúde, para João, não procede a ideia de que a prostituta é suja e vetor de disseminação de doenças, elemento muito presente especialmente na narrativa médica acerca da prostituição. De acordo com ele, elas cuidam-se muito mais, em termos de saúde, do que uma "piriguete" que você encontra nas baladas. Afinal, o corpo é o instrumento de trabalho dela. Marcos concordou com essa perspectiva, e esclareceu que hoje é muito mais tranquilo com esse aspecto da atividade de prostituição do que já foi no passado.

Quanto à relação entre a prostituição e tráfico ilícito de entorpecentes, João mencionou que, por vezes, a atividade dos traficantes atrapalha o trabalho das prostitutas. Segundo ele,

169 Tal prática de quantificação do tempo nos remete à discussão sobre a objetivação e a impessoalidade das relações no espaço urbano, tratada no Capítulo 1. 
foi o que aconteceu na 715 norte, que, no passado, era conhecida como o principal ponto de prostituição da região. Todavia, de acordo com João, começou a ter muita droga na região, e as mulheres saíram de lá. Ressalta, porém, que nunca foi de frequentar muito ali. Primeiro, pela exposição, porque seria muito iluminado lá. Assim, havia grande risco de reconhecimento, o que coloca em xeque a questão do anonimato. Depois, porque havia muito tráfico, a pessoa encostava o carro e os traficantes já ofereciam droga. Além de haver muitos moradores contrários à atividade no local.

Marcos, por sua vez, ressaltou que muitas prostitutas acabam por se tornar dependentes de drogas caras, em razão das frustações inerentes à própria atividade, como quando aparece um cliente mais agressivo ou quando há excessos de contas a pagar, e também pela facilidade que têm acesso a drogas ilícitas, pois os clientes as levam durante os programas. Ele disse que, geralmente, as pessoas que trabalham no mercado formal, e não no "submundo", usam as drogas como álcool e o cigarro para fugir dos problemas e das frustrações. No caso das prostitutas, ainda segundo Marcos, por fazer parte desse "submundo", elas têm acesso mais fácil a drogas ilícitas, que seriam suas válvulas de escape.

Sobre a regulamentação da prostituição como atividade profissional, Marcos entende que ela diminuiria um pouco o fetiche da atividade, porque profissionalizaria o negócio, e "aí vira mercadoria de verdade", retrucou. Contudo, ele mesmo ressaltou que a regulamentação é segurança para elas, na medida em que se criam relação trabalhista, sindicatos, direitos trabalhistas, auxílio-doença, auxílio-desemprego, entre outros benefícios. Todavia, ele não considerou isso necessário, pois hoje já é possível que a prostituta contribua como autônoma para a Previdência Social. Ademais, Marcos acredita também que a regulamentação aumentaria o preço do serviço, o que prejudicaria o seu fornecimento para a população de baixa renda.

\section{Policiais militares e civis}

Como já ressaltado no Capítulo 2, há no imaginário social uma estreita relação entre a prostituição e a criminalidade, uma vez que ambas são tidas como desvios sociais, o que explica o fato de haver na legislação criminal brasileira um "interdito criminal" em torno da atividade de prostituição. Apesar de esse interdito não ter alcançado a prostituição em si, criminalizando-a, ele teve larga abrangência sobre a maioria das atividades subjacentes à prostituição, como a do cafetão e a do dono do bordel, tratando-as como crimes. Essa opção legislativa, portanto, estabeleceu, ao menos em tese, um forte controle estatal em torno da 
atividade de prostituição. Ademais, como um desvio social e no imaginário social, a prostituição atrairia para seu redor, crimes oportunistas como tráfico de drogas, lesões corporais, furtos, fatores que justificam uma presença maior do Estado, consubstanciada na figura do policial.

Dessa forma, as narrativas dos policiais que atuam na W3 norte são indispensáveis para a construção do dispositivo de prostituição nessa região, e é o que passo a examinar.

Serão tratadas aqui das narrativas trazidas por três grupos distintos de policiais que trabalham nessa área: os policiais militares, os policiais civis que atuam no plantão das delegacias circunscricionais, e as delegadas de polícia da DEAM. A organização dos temas a serem tratados segue o mesmo padrão já desenvolvido nos segmentos anteriores: primeiramente, será tratada da dinâmica da prostituição, depois, das próprias prostitutas, e, por fim, das vulnerabilidades que elas estão expostas. Foram entrevistados os policiais militares Rodolfo, Carlos, Caetano, Alexandre e Daniel, os agentes de polícia Caio e Paulo, e as delegadas de polícia Ana Cristina Santiago e Patrícia Bozolan ${ }^{170}$, cujos perfis encontram-se no Anexo 2.

Quanto à dinâmica da prostituição na W3 norte, o policial militar Rodolfo confirmou que os programas são realizados nos "ambientes" das prostitutas, quitinetes localizadas na parte de trás da W3 norte. Segundo ele, cada quitinete é utilizada por aproximadamente 3 ou 4 prostitutas, que dividem o aluguel desses apartamentos, o que permite ter uma ideia mais clara de como seria um "ambiente". Aliás, a descrição dos "ambientes" como pequenas quitinetes repletas de camas remete à história contada pelo cliente João, quando ficou, em uma "sala de estar", a oportunidade de fazer programa em um dos biombos instalados no apartamento. É nesse ambiente que essas prostitutas exercem o seu trabalho e vivem uma parte significativa de sua vida.

Dito isso, o policial militar Carlos disse que o grupo das prostitutas da W3 norte é muito heterogêneo. Todas as semanas apareceriam prostitutas novas na região. No entanto, ele reconheceu que há prostituas que já estão lá há 19 anos. Destacou ainda que algumas delas apresentam condições financeiras melhores, tem bons apartamentos, fazem faculdade, malham em academia e cuidam-se muito. Outras moram em "muquifos" que fedem muito, que só tem uma cama e uma pequena passagem para chegar até esta. Tem algumas que seriam bonitas, outras, nem tanto, na opinião dele.

\footnotetext{
${ }^{170}$ Os nomes dos policiais militares e dos agentes de polícia foram alterados, para preservar a sua intimidade.
} 
Carlos informou ainda que as prostitutas mais bonitas fazem 4 ou 5 programas na mesma noite, ganham em uma hora entre $\mathrm{R} \$ 500,00$ e $\mathrm{R} \$ 600,00$, e vão embora antes mesmo da meia noite. Outras demorariam muito mais para conseguir o mesmo dinheiro. Segundo ele, o preço médio do programa seria $\mathrm{R} \$ 70,00$, dado que já confirmei anteriormente por meio da entrevista com as prostitutas. Por sua vez, o policial militar Caetano relatou que, segundo as prostitutas, a renda mensal delas é, em média, $\mathrm{R} \$ 3.000,00$, o que coincide com a informação apurada no Capítulo 3, qual seja, de que a renda mensal média das prostitutas na W3 norte fica entre $\mathrm{R} \$ 3.000,00$ e $\mathrm{R} \$ 5.000,00$.

Essas informações trazidas por Carlos revelam a existência de uma desigualdade entre as prostitutas da W3 norte, a qual é refletida na aparência de seus ambientes, que variam de "muquifos" fedorentos a bons apartamentos, como descreveu os policiais e clientes entrevistados. Tudo isso serve de alerta contra generalizações no em relação à prostituição na W3 norte.

Retomando a fala dos policiais, ainda de acordo com Carlos, o movimento maior na W3 norte é entre às $23 \mathrm{~h} 00$ e às $02 \mathrm{~h} 00$, mas é possível avistar prostitutas na avenida desde $20 \mathrm{~h} 00$. No final de semana, o movimento é mais fraco, observou, informação que confirma o relatado nos capítulos anteriores. Rodolfo, contudo, acrescentou que soube, por meio de algumas prostitutas, que, no fim de semana, algumas mulheres saem de Goiânia para fazer programa na W3 norte, alugando quitinetes para tanto. Ao que tudo indica, essas prostitutas fazem esse movimento pendular da capital goiana para Brasília, onde os programas são sabidamente mais caros, para aproveitar a menor concentração de prostitutas na região nos sábados e domingos.

Já no final das madrugadas, Carlos relatou que as prostitutas se reúnem nas barracas de cachorro quente, ratificando assim o que já tinha percebido por ocasião da observação flutuante. Contudo, ele acrescentou que há suspeitas de que essas barracas funcionam como pontos de venda de drogas, impressão essa que foi compartilhada pelo policial militar Daniel.

Sobre a distribuição das prostitutas ao longo da W3 norte, Daniel informou que hoje a W3 norte inteira está tomada, com exceção do início da avenida, próximo ao Brasília Shopping. No setor hoteleiro, segundo ele, a prostituição seria diferente, porque lá ela é escondida sob a fachada de casas de massagem. Contudo, na sua entrevista, Daniel pontuou que há quadras ao longo da via que apresentam características ou uma história específica, no que tange à prostituição. Daniel fala especificamente das quadras 704, 713 e 714 norte.

A percepção dos policiais também converge para o fato de que, na 704 norte, o consumo de drogas seria mais alto. Ali as prostitutas, como regra, são menos bonitas, e há um "muquifo" lá atrás, uma pousada, que seria utilizado por traficantes de drogas barata, para a 
venda e o consumo dessas substâncias, especialmente do crack. Caetano confirma essa visão acerca da 704 norte, e relatou que essa pousada já foi fechada, e era de fato um ponto de venda de drogas baratas. Acrescentou que, nessa quadra, as pessoas utilizam pequenos esconderijos, como buracos nas paredes, para esconder a droga, para ter apenas pequenas porções por ocasião de eventual abordagem policial.

Essas observações sugerem que existiria uma relação estreita entre a degradação do espaço urbano e a menor qualidade dos serviços de prostituição oferecidos naquele local. Ademais, as algumas das garotas de programa entrevistadas disseram evitar a área da quadra 704 norte em razão da relação com as drogas baratas.

Como vimos no capítulo introdutório, é comum a prostituição ser associada a "sujeira, a esgoto, a podridão, em suma, daquele que constitui uma dimensão rejeitável da sociedade" (RAGO, 1991, p. 23). Assim, principalmente a prostituição de rua é submetida a intensa rejeição social, que a leva a ser segregada a espaços urbanos tidos como menos valorizados, ou seja, mais degradadas. Mas a partir da observação da dinâmica específica da 704 norte, é possível concluir que nem toda degradação é igual. A degradação de certos espaços urbanos é mais intensa do que outras. Extrai-se dessas observações também que as prostitutas de rua não são o único grupo social que é empurrado para a margem desses espaços degradados. Os moradores de rua e os usuários de drogas baratas, como o crack, encontram-se na mesma situação, e a sua presença indica uma degradação do espaço urbano ainda mais intensa do que a das prostitutas. Tanto é assim que apenas as prostitutas menos arrumadas submetem-se a oferecer os seus serviços nas mesmas quadras em que estão presentes os demais grupos mencionados. Essa fala reforça ainda a ideia de que as prostitutas na W3 norte não são um grupo inteiramente homogêneo.

Por fim, ainda segundo Daniel, policial militar, na 714/314 norte, existia uma grande concentração de prostitutas, em torno da boate "Queens". Contudo, houve uma forte ação dos moradores para sua expulsão dessa quadra, que, depois, foi encampada pelo Governo do Distrito Federal. Nesse quadro, realizou-se a chamada "Operação Dragão", uma ação de presença constante da Polícia Militar na área. Segundo Daniel, quando a Polícia Militar está visivelmente presente, o cliente não para, o que reforça a ideia, tratada no segmento anterior, acerca da importância do anonimato também para o cliente. A Polícia Civil também fez várias investigações, principalmente relacionada com drogas. No geral, a polícia foi muito usada pelo governo para diminuir a prostituição nessa quadra, analisou o entrevistado.

Carlos, também policial militar, relatou que, antes da "Operação Dragão", há aproximadamente 10 anos, as prostitutas concentravam-se principalmente nas quadras 
714/715 norte, mas, a partir da referida intervenção estatal, é que elas se espalharam por quase toda W3 norte.

O caso da reação da comunidade da 714/715 norte em face da prostituição é emblemático para ilustrar o estigma que a sociedade em geral ainda impõe a essa atividade, e foi tratado de forma mais ampla no Capítulo 2. Mas aqui é importante retomar uma questão trazida nas reclamações dos moradores, como se depreendia dos jornais da época: a desvalorização dos imóveis da região, em razão da crescente presença das prostitutas. Tal queixa revela a relação de mão dupla existente entre a prostituição e degradação do espaço urbano.

Carlos mencionou ainda que, nos últimos dois anos (2014 e 2015), houve uma nova mudança na dinâmica da prostituição na W3 norte: o aparecimento dos travestis, que não existiam antes na região. Ressaltou que muitos deles parecem efetivamente mulher, e que um deles, inclusive, chegou a trabalhar na Itália, onde possui vários imóveis.

Quanto eventuais conflitos entre as prostitutas, Daniel acrescentou ainda que atualmente os setores de cada prostituta estão muito bem definidos. Elas respeitam os lugares umas da outras, e não brigam mais pelos espaços, como acontecia no passado, especialmente entre prostitutas e travestis. Isso porque, na percepção de Daniel, os travestis não querem mais problemas, e decidiram que não adiantava mais brigar.

Essa divisão do espaço entre prostitutas e travestis foi relatada também por Carlos, segundo o qual, a partir da 710 norte, em direção à 715 norte, há mais travestis, e, no sentido inverso, mais mulheres. Mas é possível encontrar mulheres e travestis em toda W3 norte, ressaltou. Essa distribuição foi confirmada, em grande medida, também na entrevista do policial militar Alexandre.

Mostra-se interessante notar que essa disputa pretérita entre prostitutas e travestis não aparece nas falas nem das prostitutas nem dos travestis entrevistados, o que reforça a ideia que elas tendem a não falar sobre os seus conflitos internos para estranhos, seja os policias, seja esta pesquisadora.

Adentrando no exame das narrativas dos policiais acerca das próprias prostitutas, uma questão fundamental é saber a percepção deles acerca das razões que levam uma pessoa a se prostituir.

Na visão de Daniel, uma prostituta traz a outra, em razão de uma relação prévia de amizade ou parentesco. O motivo é a busca do que elas acreditam que é um "dinheiro fácil", que, para Daniel, seria sim um dinheiro fácil, porque elas fazem o que "toda mulher faz, mas elas fazem mais vezes, e fazem isso ganhando dinheiro". Na sua opinião, elas estão lá porque 
querem, uma conta para a outra que podem ganhar $\mathrm{R} \$ 1.000,00$ por noite, e aí esta última resolve "ir também para pista". E, nas palavras dele, "só tem que dar, e dar você dá de graça para seu vizinho". De acordo com Carlos, as prostitutas falam que, antes, "davam" de graça, e hoje, cobram por isso. Ademais, nas palavras de Daniel, os programas são rápidos. A maioria dos clientes não passa de 30 minutos. Gozou acabou. Para ele, essa rapidez reforça a ideia de "dinheiro fácil".

O problema, para Daniel, é que, nessa vida, elas se sujeitam a várias situações complexas. Elas não podem escolher o cliente, e também estão expostas à violência. No passado, elas sofriam muito, pois apanhavam bastante dos clientes. Mas hoje em dia está bem melhor, até porque, segundo ele, "elas se profissionalizaram", e aprenderam a se impor mais. É raro ter um problema, embora Daniel tenha consciência de que muitas situações elas omitem para os policiais.

Nesse ponto, a fala de Daniel ecoa as impressões trazidas pelas delegadas de polícia Ana Cristina Santiago e Patrícia Bozolan, da DEAM. As duas ressaltaram a coragem e a personalidade prostitutas que, mesmo diante de todas as adversidades e perigo, se submetem à exposição nas ruas. Nesses termos, ela se comparou com elas e disse que não sabe se ela teria tamanha coragem, mesmo sendo uma mulher "super empoderada", já que é a Delegada-Chefe da delegacia das mulheres do Distrito Federal.

Observa-se ainda que os policiais confirmaram aquilo que já tinha sido esclarecido pelas prostitutas: muitas delas escondem da família e amigos o seu trabalho. Para tanto, criam histórias-coberturas ${ }^{171}$ para justificar a sua atividade noturna. Carlos relatou que, por muitas vezes, viu, tarde da noite, prostitutas vestidas de enfermeira, esperando no ponto de ônibus para voltar para casa, a fim de manter a narrativa falsa de que trabalhavam à noite em plantões de hospitais ${ }^{172}$.

Como se viu também no Capítulo 3, a maior parte das prostitutas admite que não conta para a sua família e amigos sobre a sua atividade de prostituição. Levam uma vida dupla, uma na realidade e outra nas mentiras que conta para as pessoas que lhe são mais próximas. É a

\footnotetext{
${ }^{171}$ História-cobertura é uma expressão utilizada por policiais para se referir a uma técnica operacional de investigação que trata de procedimentos para encobrir a realização das ações sigilosas operacionais de inteligência, objetivando a preservação dos órgãos de inteligência, da identidade dos investigadores, do material. No caso, o entrevistado fez uma analogia dessa técnica às histórias contadas pelas prostitutas às suas famílias para encobrir sua real atividade profissional na prostituição.

${ }^{172}$ Caetano, policial militar, trouxe um relato que ilustra bem a razão de elas buscarem ocultar a sua identidade. Uma vez, ele presenciou uma situação em que um casal estava brigando na parada de ônibus, porque o homem teria ido com o patrão na W3 norte para contratar prostitutas, mas encontrou sua esposa lá e daí eles começaram a discutir. Daniel recordou ainda de outro caso, em que a prostituta tem um marido que é vigilante noturno. O marido sai para trabalhar à noite, e, por volta das $21 \mathrm{~h} 00$, ela liga para ele avisando que vai dormir, mas, na realidade, sai para fazer o dinheiro dela na W3 norte. A noite toda ela faz programa com os clientes, e o marido nem sabe. Ela ajuda seu marido em casa com dinheiro e tudo. Nesse contexto, Daniel indaga: "tem diferença de uma mulher que transou a noite toda da que não transou"? Daniel considera esse dinheiro justo. O único problema que ele vê com a prostituição é a associação com o crime, com as drogas, contou.
} 
maior exemplo da força que tem, ainda hoje, o estigma de prostituta, e a importância do anonimato no seu dia-a-dia.

Observa-se que muitas prostitutas levam uma vida dupla em ainda outro sentido. Por exemplo, Carlos ressaltou que muitas das prostitutas de rua da W3 norte, durante o dia, trabalham em casas de massagem. Assim, têm uma cansativa dupla jornada, que faz com que elas envelheçam mais rápido, analisou Carlos. É difícil ver como, tomando como referência o mundo da vida e não o imaginário social, essa vida poderia ser qualificada como uma "vida fácil”.

Quanto à vulnerabilidade das prostitutas na sua atividade profissional, Daniel ponderou que elas “não são essas santas". Segundo ele, elas fazem parte do problema, pois a maioria é usuária de drogas, e, por vezes, também atuam como traficantes. Tal percepção é compartilhada por todos os policiais entrevistados. Caetano ressalta que algumas utilizam a prostituição como uma camuflagem para sua verdadeira atividade econômica: o tráfico ilícito de entorpecentes, como, aliás, também foi relatado pelas prostitutas entrevistadas, como visto no Capítulo 3.

Os policiais civis Caio e Paulo relataram que, nas suas investigações, observaram, por diversas vezes, as prostitutas, encomendado drogas para seus clientes, a partir da discrição de seus "ambientes", ou mesmo para vender em seus pontos de prostituição. Segundo eles, algumas chegam a esconder as drogas em seus "ambientes", para o traficante com quem trabalham, e o espaço passa a funcionar como um depósito de entorpecentes. Eles informaram que, até pouco tempo, havia um traficante que tinha a hegemonia na região da 703/704 norte, utilizando-se, para tanto, de ameaças e violência. Ele foi preso, em razão de uma investigação levada adiante pela $2^{\mathrm{a}} \mathrm{DP}$. Ainda segundo os policiais, esse grupo mantinha a W3 norte sobre constante vigilância, para se resguardar tanto contra ações de rivais quanto da polícia. Apuraram que uma prostituta pode tirar até $\mathrm{R} \$ 1.800,00$ por dia, atuando no tráfico ilícito de entorpecentes.

Caetano relatou ainda que, na W3 norte em geral, relacionada à atividade de prostituição, há uma incidência maior de cocaína, e não tanto de maconha. Isso porque, segundo ele, a maconha é mais difícil de carregar e esconder, em razão do seu maior volume, e, por outro lado, é possível esconder a cocaína dentro das roupas íntimas das prostitutas. Além disso, ainda de acordo com o policial, o crack também não seria muito difundido, a não ser, como se viu, na área da quadra 704 norte. Em uma noite, vendendo a grama de cocaína a $\mathrm{R} \$ 50,00$, podem fazer $\mathrm{R} \$ 500,00$ sem maiores dificuldades, o que torna a atividade atrativa para uma parte delas. Ademais, de acordo com Daniel, as prostitutas da W3 norte não gostam 
de utilizar droga barata, como maconha, mas apenas drogas mais elitizadas, como cocaína, normalmente associada com bebida alcóolica, que, muitas vezes, consomem em conjunto com o cliente. Nas palavras de Daniel, "se o cliente quiser ela tem, e se ela não tiver, sabe quem tem". Mas na maioria das vezes, elas têm drogas, e chegam, inclusive, a ter a iniciativa de oferecê-las a seus clientes.

Daniel afirmou que tem uma boa relação com as prostitutas da W3 norte, e que, em alguma medida, elas lhe contam tudo. Disse que, quando há um suspeito na área, elas avisam para a polícia. Para ele, os policiais militares sabem que elas estão envolvidas com drogas, mas eles fazem "vista grossa", porque não podem declarar guerra contra elas. "A prostituição está quase institucionalizada", contou.

Todavia, Daniel relatou ainda, nos últimos tempos, não tem tido notícia de agressões envolvendo prostitutas, mas reconheceu que esses casos frequentemente não chegam ao conhecimento da polícia, principalmente no caso de problemas entre as próprias prostitutas. Caetano confirmou essas impressões, o que reforça a hipótese acima formulada de que, como regra, elas não comunicam os episódios de violência para agentes estranhos ao meio social em que elas vivem. Mesmo assim, Daniel manifestou a opinião de que a violência contra as prostitutas diminuiu, quando comparado a tempos passados. Relatou ainda que, quando a prostituta tem um problema com um cliente, o boato espalha, e o cliente fica "queimado"173.

As informações dos policiais militares são harmônicas com aquelas relatadas pelas delegadas da DEAM, já mencionadas nos capítulos anteriores. Patrícia Bozolan informou que a DEAM não recebia muitos casos ligados à atividade de prostituição, porque as ocorrências eram mais pulverizadas entre as delegacias circunscricionais. Ela disse que, na prática, apenas um tipo de caso chega à DEAM: quando há uma ameaça reiterada por parte dos atores da prostituição, como o cafetão, nas quais as prostitutas se sentem muito ameaçadas em sua vida e integridade física. Para justificar essa escassez de ocorrências, Ana Cristina Santiago referese à própria natureza do trabalho de prostituição e a personalidade firme das prostitutas, que, segundo ela, são extremamente fortes e corajosas e não procuram a delegacia por motivos que elas julgam pequenos e que são inerentes à profissão.

Carlos relatou que, muitas vezes, as prostitutas chamam a Polícia Militar, quando o cliente não quer pagar o programa, e aí surgiria um desentendimento entre os dois. Regra

\footnotetext{
${ }^{173}$ Sobre esse tema, Daniel contou que, alguns meses antes, houve o caso de um policial federal que dava "carteirada" nas prostitutas, para não pagar os programas. A "carteirada" é uma prática ilegal de policiais que apresentam sua identificação policial para ter acesso a serviços gratuitos como espetáculos, cinemas, festas, por exemplo. Segundo Daniel, essa prática da "carteirada" também acontece nos serviços de prostituição e, no caso relatado desse policial federal em específico, ele disse que já ocorreu em outras oportunidades. "Uma vez, as prostitutas quebraram os vidros do carro dele. A polícia militar foi chamada, mas ele mesmo não quis ir à delegacia, para evitar o escândalo", lembrou.
} 
geral, a mera chegada dos policiais militares basta para que o cliente pague ou deixe o local ${ }^{174}$. Ele mencionou também casos de "roubo", em que o cliente não paga o travesti, e ele pega alguma coisa desse cliente. Segundo ele, esses tipos de ocorrência, os policiais militares tentam resolver no local. É o que os policiais chamam de "1010"175.

Carlos destacou ainda que as prostitutas ficam muito expostas na W3 norte, chamando à atenção de autores de crimes patrimoniais. Caetano confirmou essa impressão e disse que não apenas as prostitutas ficam expostas, mas os clientes que, pelo menos, têm maior proteção, porque estão nos veículos. Nesse sentido, Alexandre tomou conhecimento de vários casos em que a pessoa faz se passar por cliente e furta, por exemplo, o celular da prostituta. Segundo Carlos, a aproximação da viatura policial serviria para afugentar esses "vagabundos", o que reforçaria a confiança das prostitutas nos policiais militares, ao menos na percepção do entrevistado.

Todos os policiais militares relatam sobre a existência de cafetões na W3 norte. Todavia, Daniel informou que a questão do cafetão diminuiu muito na W3 norte, e a maioria das prostitutas são hoje independentes, mais profissionalizadas, ao menos na percepção dele. Por sua vez, Caetano relatou que, no passado, havia uns caras que vinham de Ceilândia, vigiavam e cobravam pela vigilância das prostitutas. Mas elas não reclamavam muito deles para polícia, porque elas temiam retaliações por parte destes indivíduos.

Finalmente, sobre o tema da regulamentação da prostituição, Daniel disse que não conseguia vislumbrar o futuro com a liberação, pois não conseguia ver quais são os benefícios e os prejuízos. Por outro, ponderou que, com a regulamentação, vai existir outra coisa, porque "o ser humano gosta do submundo, do proibido, do diferente". Carlos também disse acreditar que, se regulamentar, perderia "a graça", pois deixaria de ser algo proibido. Caetano considerou que regulamentar a prostituição seria complicado, na medida em que elas seriam autônomas, iriam alugar uma casa para fazer as próprias pousadas. Alexandre, por sua vez, afirmou que, apesar de ser uma questão complicada, poderia ser uma alternativa, porque elas poderiam ter um local mais apropriado para atender, o que melhoraria a vida para elas.

\footnotetext{
${ }^{174}$ Carlos lembrou ainda de um caso, em que a sua equipe foi chamada, porque a prostituta combinou com ela o sexo vaginal e o oral, e, chegando lá, ele fez sexo anal. E ele não tinha pagado por aquilo. E aí ela interrompeu o programa, saiu correndo, e chamou a polícia. Os policiais fizeram uma negociação, e a prostituta e o cliente chegaram num acordo. Caetano relatou ainda que há casos em que, quando o cliente goza rápido demais e quer manter nova relação sexual, e a prostituta cobra um novo programa, e ele não quer pagar novamente, surge um desentendimento. Mas, quando se fala em ir para a delegacia, nenhuma das partes quer, tanto a prostituta quanto o cliente, e daí o próprio cliente paga.

175 "1010", segundo me contaram os entrevistados policiais militares, é o código utilizado nos formulários internos da instituição para indicar que um problema foi resolvido pelos próprios policiais militares acionados no local, sem a necessidade de maiores providências.
} 


\section{Notas para um dispositivo da prostituição feminina na W3 norte a partir da percepção de clientes e policiais}

Tendo como base as informações obtidas nas entrevistas com os clientes das prostitutas da avenida W3 norte, e com os policiais militares e civis que atuam diretamente na região acrescento mais notas à construção do nosso dispositivo.

Para tanto, destaco, por sua relevância, três aspectos mencionados nessas entrevistas: o anonimato, as relações de poder e a questão com as drogas ilícitas.

$\mathrm{O}$ anonimato na prostituição tem uma dupla dimensão, porque ele se mostra relevante tanto para os clientes quanto para as prostitutas. O envolvimento com a prostituição trata-se de um estigma social negativo para ambos.

Para o cliente homem, pode representar um risco de tornar pública a sua inabilidade social para manter relações sexuais por meio dos mecanismos tradicionais de conquista, além de apresentar um risco direto ao dispositivo de sexualidade tradicional e da família, por meio da traição do casamento monogâmico.

Já para a prostituta mulher, ser vista como tal pela família e amigos, em grande medida, constitui uma degradação em sua posição na sociedade. E, dessa forma, a ocultação constante de sua verdadeira atividade profissional, inclusive para o seu ciclo de pessoas mais íntimas, representa uma situação constante de insegurança e ansiedade, causada pelo temor incessante da iminente revelação de seu segredo. Sem dúvidas, essa circunstância tem influência direta na construção de suas identidades e na forma com a qual elas lidam com as vulnerabilidades decorrentes da prostituição.

Ainda sob um aspecto mais subjetivo, a partir das entrevistas, foi possível apreender outro significado para o anonimato na prostituição. Ao se relacionar com a objetivação e a impessoalidade desse tipo de relação sexual, o anonimato possibilita a realização de fantasias e desejos sexuais, que não seriam trazidos à tona no contexto de relações sexuais expostas ao público. Tais práticas poderiam, por exemplo, revelar eventual bissexualidade ou homossexualidade do cliente, ou exotismo das práticas sexuais de sua preferência, muitas vezes incompatíveis com a presença de relações afetivas e sentimentais, como acentuou o cliente Marcos. Nesse sentido, seria possível identificar também aqui a forte influência do tradicional dispositivo de sexualidade, intimamente ligado a questões hereditárias e ao casamento. Assim, a prostituição, com sua objetivação e garantia de anonimato, serviria como uma válvula de escape a interditos impostos a certos tipos de sexualidade. Sob esse aspecto, 
pode se dizer então que há um quê de subversivo na prostituição, tema que será melhor tratado no próximo capítulo.

Também no contexto do anonimato e da objetivação, outro aspecto ressaltado nas falas dos entrevistados diz respeito às relações de poder entre clientes e prostitutas, nas quais a posição do dominador é variável, ora ocupada pelo cliente, que demanda pelas fantasias e detém o dinheiro, e ora pela prostituta, a realizadora de seus desejos e que, por vezes, o intimida com beleza ou habilidades sexuais. Todavia, essa relação de poder é instável, principalmente para as prostitutas que se envolvem facilmente com o consumo de entorpecentes ilícitos, cujo acesso é facilitado pelas próprias características da prostituição, pautada pelo anonimato e pela discrição.

Essa questão das drogas merece especial atenção, e está estreitamente relacionada com a ideia de que a prostituição na W3 norte é uma "vida difícil", e não uma "vida fácil", como presente no imaginário social, inclusive dos policiais e dos clientes, como visto acima. Ao longo do capítulo, foram exploradas muitas circunstâncias, que permitem concluir que a vida dessas prostitutas é sim muito difícil: a eterna vigilância para preservar o anonimato, o risco permanente de agressões, o forte estigma que a recai sobre a sua atividade profissional, a longa jornada de trabalho etc. De acordo com policiais e clientes, tudo isso conduz muitas delas a buscar refúgio desses problemas nas drogas. Outras ainda adquiriam o vício, por muitos clientes demandarem que elas utilizem drogas junto com eles durante o programa.

Todavia, segundo os policiais, parte delas se dedicam também ao tráfico ilícito de entorpecentes na W3 Norte, principalmente por meio do fornecimento de drogas para seus clientes no curso do programa. Outras ainda utilizam a prostituição como mera camuflagem para o tráfico, sua atividade principal, e não simplesmente uma atividade paralela.

No próximo capítulo adicionarei mais complexidade ao nosso dispositivo de prostituição da avenida W3 Norte, trazendo à discussão as visões de como a academia, em suas diferentes perspectivas teóricas, trata dessas questões e os paradoxos relacionados à prostituição. 


\section{Capítulo 5. Elas, na versão da Academia}

\section{Conhecimento, representação social, campo científico e campo intelectual feminista.}

Nos capítulos anteriores, apresentei as diversas representações sociais que se situam em torno da ideia de atividade de prostituição. Nesse conjunto, estão incluídas tanto as narrativas moral, religiosa, médica, jurídica, espacial, quanto as narrativas relacionadas à atividade na avenida W3 norte, elaboradas pelas próprias prostitutas, seus clientes, e policiais que lá trabalham.

No presente capítulo, serão tratadas as representações sociais acerca da prostituição desenvolvidas em uma parte do campo intelectual feminista. A pretensão não é esgotar o assunto, mesmo porque há inúmeras vertentes, variações e combinações inclusive com outras demandas de movimentos sociais, como o movimento negro, e de perspectivas teóricas, como o decolonialismo e pós-colonialismo.

Mas, para compreender a dinâmica dessas representações, é necessário, em primeiro lugar, examinar brevemente a forma como a academia constrói suas próprias representações sociais, aquilo que nomeia de conhecimento científico. Para tanto, será tomada como referência a teoria dos campos desenvolvida por Bourdieu ${ }^{176}$, em especial no que concerne aos seus estudos sobre o funcionamento do campo científico.

Descrever e observar como se dá a produção do conhecimento científico foi uma das grandes preocupações de Bourdieu, que elaborou vários conceitos: "campo", "habitus", “doxa", "capital especifico”, os quais integram sua teoria sobre os campos.

A noção de campo refere-se à ideia de delimitação do espaço social. Ele considerava a sociedade como um conjunto relacional composto por vários "campos", que são definidos pela relação ou pela distinção entre eles. Campo também está ligado ao local onde são travadas muitas batalhas e lutas, e é exatamente essa noção que Bourdieu quis ressaltar ao definir a ideia de campo. Para esse autor, um campo "se define entre outras coisas através da delimitação dos objetos de disputas e dos interesses específicos que são irredutíveis aos

\footnotetext{
${ }^{176}$ Em primeira vista, a "teoria dos campos" de Bourdieu pode parecer abstrata, mas ela foi baseada em várias observações da realidade social e também em várias pesquisas empíricas, o que a torna bem mais interessante. Bourdieu, inclusive, apesar de sua formação filosófica, não era adepto às divisões intangíveis entre teoria e empiria, o que para ele era uma limitação no entendimento da prática social. Ele mesmo ressaltou que, "de fato, todo o meu empreendimento científico se inspira na convicção de que não podemos capturar a lógica mais profunda do mundo social a não ser submergindo na particularidade de uma realidade empírica, historicamente situada e datada, para construí-la, porém, como 'caso particular do possível', conforme a expressão de Gaston Bachelard, isto é, como uma figura em um universo de configurações possíveis". (BOURDIEU, 1996, p. 15)
} 
objetos de disputas e dos interesses próprios dos outros campos ${ }^{177 "}$ (BOURDIEU, 1983, p. 89)

No campo acadêmico, há disputas internas entre seus vários agentes para determinar o significado dos seus conceitos mais importantes, como, no caso da Sociologia, qual seria o conceito de indivíduo, de sociedade, de gênero, de cultura. Existem também disputas externas, nas quais a academia tenta ganhar posições perante outros campos, como o do poder e da economia.

O funcionamento dessas disputas internas dentro do campo acadêmico merece especial atenção, pois, como se verá, o objeto do presente capítulo será precisamente examinar as disputas internas dentro de um campo acadêmico específico, o campo intelectual feminista, no pertinente ao significado da atividade de prostituição. E para compreender essa dinâmica é necessário determinar o que está em jogo no campo acadêmico em geral, e no campo intelectual feminista especificamente.

Nesse ponto, é importante entender o conceito de capital específico para compreender a dinâmica dessas disputas internas, pois ele funciona tanto como objeto da disputa em si quanto como uma arma nessa batalha, por meio da qual esse enfrentamento é levado adiante. Assim, de maneira simplificada, pode-se entender o capital específico como uma forma de poder particular de determinado campo específico, como o poder de dizer o que é lícito e o que é ilícito, característico do campo jurídico. O capital específico é distribuído dentro do campo de acordo com a influência que cada agente possui dentro deste. Ou seja, a disputa no campo é sempre por mais influência ou poder dentro desse campo, e quanto mais influência ou poder dentro do campo, ou seja, quanto maior o capital específico reunido, maior a posição do agente dentro do campo. Portanto, é o maior ou menor acúmulo de capital específico que determinará, em linhas gerais, a posição e a autoridade do agente dentro do campo.

Todavia, a disputa interna pelo capital específico não se dá livremente, mas de acordo com parâmetros consolidados no campo, e entre eles destaco aqui o que Bourdieu chamou de doxa. A doxa apresenta-se com a forma de comunicação mínima dentro do campo, ou seja, a linguagem básica utilizada pelos integrantes do campo, os quais devem dominá-la para adquirir o tal capital específico mínimo para entrar e permanecer no campo. Por exemplo, no

\footnotetext{
${ }^{177}$ Os agentes de cada campo têm interesses diferentes, investem seus estudos e tempo em assuntos diferentes, e, nessa medida, participam de campos diferentes. Todavia, a organização do espaço social em campos mostra-se efetivamente dinâmica, pois existem em cada campo disputas de natureza tanto interna quanto externa. A disputa interna se dá entre os distintos agentes dentro do mesmo campo, cada um com um grau de autoridade distinto, em decorrência da sua inserção dentro do campo, ou posição no campo, no vocabulário de Bourdieu. Já na disputa externa, os diferentes campos disputam na arena pública as benesses do capital político. É o que ocorre, por exemplo, quando os economistas atuam para convencer os agentes responsáveis pelo financiamento de pesquisas acadêmicas, que investir em bolsas de estudos na sua área de conhecimento é melhor, do ponto de vista do interesse público, do que em outras áreas, como a filosofia.
} 
campo científico, a linguagem mínima de comunicação é baseada nas ideias de racionalidade e distanciamento. Sem observância à $\operatorname{doxa}^{178}$, não há comunicação, não há campo, não há jogo. É o discurso comum da doxa que vai definir, em grande medida, a identidade do campo, bem como quem dele participará e terá acesso ao seu capital específico. Um dos mais importantes elementos da doxa é o que se chama de crença, ou seja, a circunstância do sujeito acreditar que há um valor no que está sendo disputado. Por exemplo, um cientista, um agente do campo científico, engaja-se na produção de conhecimento científico, com a doxa em torno da racionalidade e distanciamento, porque ele acredita na existência do campo científico.

Nesse quadro, aqueles que detêm maior capital específico, ou seja, influência dentro do campo, tendem a ter estratégias de conservação do poder e, por isso, adotam, segundo Bourdieu, posições ortodoxas. Já os detentores de menos capital específico, tendem a estratégias de subversão, ou seja, heresia ou heterodoxia (BOURDIEU, 1983, p. 90). Repare que, nas duas posições, mesmo que extremas, há, ainda a preservação da doxa, ou seja, a linguagem mínima, pois, caso contrário, haveria uma situação semelhante à do jogador que "pega a bola" e vai embora. Game over.

Dito isso, nota-se que tanto o campo acadêmico quanto o intelectual feminista inseremse entre os chamados campos de produção cultural, que, por sua vez, são caracterizados pela disputa de poder de dizer o significado das coisas, em especial no que tange às suas representações sociais.

E é exatamente utilizando esses conceitos plásticos e operáveis sobre a teoria dos campos, desenvolvidos por Bourdieu, que, será analisada a questão de um campo intelectual feminista.

Inicialmente, cumpre ressaltar que os assuntos referentes à posição da mulher na sociedade perpassariam, segundo o modelo da teoria dos campos de Bourdieu, por vários "campos" do mosaico social como, por exemplo, o moral, o religioso, o médico, o jurídico, como já se viu especialmente na introdução. Cada um apresenta narrativas próprias acerca da prostituição. Assim, pode-se dizer que a questão do feminino, da posição e do papel da mulher na sociedade, é transversal ${ }^{179}$, de modo a abranger vários campos, que trabalham a

\footnotetext{
178، A doxa constitui a chave seletiva imposta tacitamente por todos os campos, excluindo aqueles que destroem as regras do jogo e promovendo operações de seleção e formação aos recém-chegados, de modo a obter deles um acordo tácito aos pressupostos fundamentais do campo.” (MARTINS, 2002, p. 178).

179 "Sabemos que o pensamento feminista não se constitui em um corpus unificado de conhecimento, e sabemos igualmente que o construto gênero foi apropriado das formas as mais distintas pelas inúmeras áreas disciplinares e suas teorias, mas é fundamental salientar que, sendo essa aproximação mais superficial ou mais substantiva, todos deveriam partir de um ponto comum que seria o da subordinação da mulher ao homem, para entender e explicitar, relacionalmente, as muitas vicissitudes de como tais relações de dominação e opressão são elaboradas socialmente. O conceito também abriu espaço analítico para se questionar as próprias categorias de homem e de masculino, bem como de mulher e de feminino, que passaram a ser fruto de intenso processo de desconstrução." (MATOS, 2008, p.336).
} 
questão, internamente e também externamente, ou seja, no contexto das relações e disputas dentro e entre os campos.

Historicamente, a questão feminina ganhou maior destaque político com o movimento feminista, que, na sua primeira fase ou onda, lutou pelo direito das mulheres de votar e serem votadas a cargos públicos eletivos. ${ }^{180}$

O crescimento e desenvolvimento dos movimentos de liberação feminina, no campo político, introduziu uma série de novas perspectivas e interrogações às diversas áreas de conhecimento acadêmico. A própria epistemologia do saber dominante passou a ser atacada, ao argumento de que camuflava um acesso privilegiado do masculino à ideia de neutro, sob o véu do distanciamento e da racionalidade, que são dois dos principais elementos da doxa ou narrativa científica. A partir daí, é possível ter uma ideia da força e abrangência das novas perspectivas trazidas pelo movimento feminista na academia.

A necessidade de tratar dessas novas perspectivas fez surgir, nas universidades e institutos de pesquisa, espaços próprios para discuti-las, como a organização de grupos de estudo e a edição de revistas acadêmicas feministas. Operou-se aí uma tradução das ideias mencionadas do campo político para o campo da produção científica, principalmente para o campo das ciências sociais, que possui dinâmica e capital específico, nos termos de Bourdieu, bem diversos dos movimentos sociais. Embora, em alguma medida, tanto os movimentos sociais quanto os profissionais da academia integrem o campo da produção cultural, responsável pela produção das representações sociais de dada sociedade, cada um deles opera de forma distinta. Tal diferença está presente, por exemplo, na postura que um e outro grupo assumem diante das grandes polêmicas: enquanto os movimentos sociais falam de uma posição de expresso engajamento, os profissionais da academia lecionam de uma posição de pretenso distanciamento e objetividade. Explica-se tal diferença pelo fato de os movimentos sociais e os profissionais da academia pertencerem a campos específicos diferentes, que possuem características diferentes, nos moldes acima indicados, embora mantenham relações no contexto do espaço social mais amplo.

Nesse contexto, a partir dessa tradução das ideias feministas do campo dos movimentos sociais para o campo acadêmico, surge o chamado "campo intelectual feminista", que, por

\footnotetext{
180 "O grande esforço da primeira onda do feminismo foi o de questionar, refletir, procurando desconstruir inúmeras formas de instituições e relações patriarcais no seio das quais se mantinham e se reproduziam estratégias de dominação masculina; isso se dando na arena da luta pelo sufrágio universal. Ou seja, tratou-se de uma batalha pela afirmação da condição fundamental e democrática da igualdade política entre os sexos (articulada evidentemente à dimensão universal)". (MATOS, 2008, p.338).
} 
suas especificidades, assumiu uma identidade distinta do campo do movimento militante feminista.

Diante disso, mostra-se importante localizar o campo intelectual feminista dentro do espaço social. Conforme dito, o campo intelectual feminista inscreve-se dentro do campo da produção científica, que, por sua vez, inscreve-se dentro do campo da produção cultural. Assim, ele assume características dos dois campos mencionados, por meio de uma relação de homologia, segundo a qual a organização de um campo se dá de forma similar aos campos mais amplos aos quais está relacionado, respeitadas sempre as particularidades de seu capital específico. Por isso, a referida relação é de semelhança, e não de identidade. Assim, um rápido exame dos campos da produção cultural e da produção científica decerto é útil para compreender a estrutura específica do campo intelectual feminista.

Inicialmente, o campo da produção cultural pode ser definido pelo seu capital específico, que é o poder de construir as formas de percepção e de apreciação do mundo, a definição do que é importante e o que não é, do que merece ser representado e do que não merece $^{181}$.

Por seu turno, o campo de produção científica pode ser caracterizado por certos elementos do seu discurso, como a preocupação com a racionalidade, o distanciamento e suposta neutralidade em relação ao seu objeto. Contudo, as militantes do movimento feminista consideraram que "ao aceitar as regras do jogo científico, os grupos e os indivíduos se deixaram aprisionar no jogo, aceitando tomar partido dos poderes institucionais, para neutralizar e normalizar os estudos sobre as mulheres, retirando toda sua visão subversiva" (LAGRAVE, 1990, p. 3). Afinal, o que caracteriza o capital específico do campo científico, entre outras coisas, é a produção de representações sociais com pretensão de racionalidade e distanciamento.

Dessa forma, o campo intelectual feminista não se confunde com o movimento militante feminista. São distintos os valores que caracterizam um e outro grupo. Todavia, o campo intelectual feminista é influenciado fortemente pela sua origem militante das ideias feministas das quais se apropriou. Dessa forma, existe certa ambiguidade ou ruído no campo, de forma que é possível identificar em integrantes do campo intelectual feminista pontos comuns entre as posições extremas de "pesquisadoras ortodoxas" e "militantes feministas".

\footnotetext{
${ }^{181}$ Nos termos de Bourdieu, seria "o poder propriamente simbólico de fazer com que se veja e se acredite, de trazer à luz, ao estado explícito, objetivado, experiências mais ou menos confusas, fluidas, não formuladas, e até não formuláveis, do mundo natural e do mundo social, e, por essa via, de fazê-las existir" (BOURDIEU, 2004, p. 176).
} 
Há ainda quem recuse a inscrição do feminismo no campo intelectual, pois seu caráter militante seria incompatível com o exercício da atividade científica. Todavia, esses críticos esquecem-se de que grande parte do pensamento filosófico e científico tem também como mola propulsora uma forma ou outra de pensamento utópico ou ideológico (MACHADO, 1994, p. 5-6). Parece ser, então, um argumento que não se sustenta.

O campo intelectual feminista emerge, dessa forma, de duas fontes, que vão se combinar para formar a sua identidade: a) os saberes disciplinares que com ele dialogam no âmbito acadêmico (e o feminismo relaciona de modo transversal inúmeras modalidades de conhecimento, como a sociologia, a psicologia, a literatura, a filosofia etc.); b) o feminismo militante, por forjar novas formas de interrogar e de priorizar a temática (MACHADO, 1994, p. 3).

Todavia, as questões em torno da diferença sexual, da divisão sexual do trabalho e das respectivas relações de poder entre homens e mulheres, já haviam sido objeto de análise pelas diversas ciências humanas. Assim, por que diríamos que apenas com o movimento feminista houve o "surgimento de um campo intelectual feminista"?

A resposta à questão está no objeto do campo, ou seja, no capital específico do campo intelectual feminista, que coloca as ideias de caráter social naturalizado das diferenças sexuais e de "dominação masculina" como categorias centrais. Isso porque, antes, elas eram relegadas à posição de um problema secundário dentro dos diversos saberes disciplinares que, ao longo dos anos, cuidaram do assunto (MACHADO, 1994, p. 5). ${ }^{182}$

A partir dessas considerações, advoga-se pela autonomia do campo intelectual feminista, em face dos demais campos mencionados. Com isso, passa-se a examinar as características desse campo, em especial aquelas que serão úteis para a compreensão dos discursos sobre a prostituição que se desenvolveram dentro dele.

A primeira tarefa é determinar qual seria o capital específico do campo intelectual feminista, pois, conforme mencionado, é ele que, em grande medida, define a identidade do campo, uma vez que ele se constitui como objeto de disputa. O ponto de partida, então, é o capital específico do campo das ciências sociais, que trata da produção de representações sociais, na forma de conhecimento científico, acerca das relações sociais. A diferença é que o campo intelectual feminista não cuidaria de uma relação social comum, mas apenas de uma relação específica: a dominação masculina por meio da construção social da diferença entre os

\footnotetext{
${ }^{182}$ O feminismo militante contribuiu ainda para a superação de certo discurso que banalizava a questão da dominação masculina, ao argumentar que a sociedade moderna "naturalmente" tende para o progresso e a igualdade dos sexos (MACHADO, 1994, p. 5).
} 
sexos, e trataria do tema de forma transversal entre os demais ramos do conhecimento, não ficando adstrito à sociologia.

Por sua vez, no que concerne à doxa do campo intelectual feminista, dois elementos discursivos chamam à atenção: o reconhecimento do domínio masculino; e o projeto de igualdade político-social entre homens e mulheres, forte herança de sua raiz militante.

Dito isso, para além dessa doxa, há diversas disputas internas dentro do campo, entre as quais destaca-se aquela que separa duas correntes: as "diferencialistas" e as "igualitaristas". Os dois grupos divergem sobre o papel a ser desempenhado pelas categorias de diferença e de dominação na construção da teoria feminista ${ }^{183}$.

As igualitaristas têm como categoria central a ideia de dominação masculina. A situação qualitativa que dá unidade às mulheres é a sua subordinação ao homem, o que torna secundária a diferença específica das mulheres em relação aos homens e das mulheres entre si. O seu projeto político-social é reformar a ideia de universal, para que ela deixe de ser um domínio exclusivo do masculino. Nesse contexto, as teorias que enfatizam as diferenças biológicas e culturais entre homens e mulheres seriam tidas como perigosas, pois prejudicariam o entendimento universal (pautado pelas semelhanças e não pelas diferenças) e conduziriam a uma concepção essencialista da condição feminina, e, por consequência, à legitimação da sua dominação (MACHADO, 1994, p. 9).

Essa corrente parte do conceito estruturalista da diferença, segundo o qual toda operação lógico-valorativa de diferenciação implica opor e comparar dois termos, de tal modo que um é referência para outro. Não há assim equivalência de valor entre eles, do que resulta a desvalorização de um em favor do outro, no caso, do feminino em benefício do masculino.

A visão das igualitaristas sobre a diferença fica evidente, por exemplo, no seu tratamento da questão da maternidade, aqui bem retratada por Grosz:

O corpo feminino limita a capacidade das mulheres para igualdade e transcendência; é um impedimento a ser superado, um obstáculo a ser vencido se se deseja obter igualdade. Muitas feministas nesta categoria veem um conflito entre o papel de mãe e o de política ou cidadã. Se a mulher adota o papel de mãe, seu acesso à esfera pública, social, torna-se difícil, se não impossível, e a equidade dos papéis dos dois sexos perde o sentido. No melhor dos casos, a equidade das relações entre os sexos só é possível na esfera pública. A esfera privada permanece sexualmente polarizada já que os papéis sexuais, especialmente papéis reprodutivos, permanecem

\footnotetext{
${ }^{183}$ Frise-se que, como já dito, existe grande variedade de perspectivas dentro do campo intelectual feminista, a qual não pode ser resumida apenas à dicotomia 'igualitarista' e 'diferencialista', ou, como se verá adiante, 'feminista radical' e 'feminista liberal'. Há ainda, por exemplo, a perspectiva trazida pelos movimentos negros, pelas teorias decoloniais, entre outros. Contudo, escolhi abordar os grupos e as perspectivas mencionadas, pois são os que mais comumente tratam da temática da prostituição no contexto das teorias feministas.
} 
binariamente diferenciados. Beauvoir e Firestone apostam no desenvolvimento de novas tecnologias reprodutivas para a eliminação dos efeitos da biologia específica das mulheres em seus papéis como seres sociais, econômicos, culturais e sexuais. (...)

A diferença entre ambas reside no fato de que para tais feministas da igualdade, a maternidade é o que deve ser superado, enquanto que para as que advogam os programas in vitro, a maternidade é o objetivo, ou o objetivo mais importante, da feminilidade. "São os lados positivo e negativo da capacidade geradora das mulheres (GROSZ, 2000, p. 71).

Já as diferencialistas apostam na categoria de alteridade para construir a sua crítica à dominação masculina e estabelecer o seu projeto político-social, distinto daquele das igualitaristas. Diversamente do conceito de diferença, na sua origem, a alteridade trata simplesmente da distância entre duas culturas, cuja única identidade comum seria o "espírito humano", sem realizar qualquer operação de comparação e valorização (e, por conseguinte, de desvalorização) (MACHADO, 1994, p. 18). Ou seja, a cor vermelha e a cor amarela são apenas cores diferentes, e não mantém qualquer relação de oposição e valoração.

Tal concepção foi pensada também pela antropologia estruturalista para relacionar culturas distantes uma das outras, e não dois grupos imersos no mesmo caldo cultural. No entanto, a simples possibilidade de se cogitar na ideia de alteridade demostra que não há, abstratamente, uma relação necessária entre comparação e valoração. Ou seja, a cor amarela não é mais bonita que a cor vermelha só porque elas são diferentes. É possível pensar que duas coisas são distintas, sem que disso resulte a desvalorização de uma ou de outra. Assim, pode-se considerar que homens e mulheres são qualitativamente distintos, sem que disso resulte necessariamente qualquer desvalorização a mulher, ou a legitimação da dominação masculina.

De acordo com as diferencialistas, toda relação de dominação se dá no contexto de uma relação de alteridade, sem que esta se reduza àquela, e sem qualquer essencialismo histórico. Somente afastando-se da identidade entre alteridade e dominação é que se pode pensar a historicidade das relações de dominação, que, pelo contrário seria eternizável, pois inseparável da simples constatação da diferença entre os sexos (MACHADO, 1994, p. 19).

É a possibilidade dessa diferença sem desvalorização que serve de ponto de partida para o projeto político-social das diferencialistas. A emancipação das mulheres da dominação masculina, não pela dissolução de homens e mulheres em uma universalidade, mas por meio de um reconhecimento da uma igualdade político-social que preserve a especificidade 
identitária dos referidos grupos, seja biológica seja cultural. Aliás, reconhecem a existência de uma pluralidade de feminilidades que devem ser preservadas na sua particularidade, possuindo, portanto, um claro viés multiculturalista.

E é no contexto dessa diferença entre igualitaristas e diferencialistas que devem ser compreendidos e trabalhados os diferentes entendimentos acerca da prostituição trazidas pelas feministas radicais e pelas feministas liberais. É o que se fará a seguir.

\section{2. (Dis)putas no campo intelectual feminista pelo significado da prostituição}

O papel desempenhado pela prostituição no contexto da dominação masculina é hoje um dos temas mais polêmicos dentro do campo intelectual feminista, que se divide, quanto ao tema, em dois grandes grupos, as feministas radicais e as feministas liberais, embora existam inúmeras variações. Ambos reconhecem a importância da discussão sobre a prostituição na luta comum em favor da superação da dominação masculina e da construção de uma efetiva igualdade político-social entre homens e mulheres, o que, aliás, faz parte da doxa feminista, conforme visto acima. A discordância, contudo, reside na valoração ou significação da prostituição, e das consequências, em termos de políticas públicas, que se extrai daí.

Para o primeiro grupo, o das feministas radicais, a prostituição é uma das formas mais extremas da dominação masculina. As feministas radicais sustentam:

o entendimento de que a prostituição é uma violência contra a mulher - violência
não somente na prática da prostituição, mas ainda mais fundamentalmente pela ideia
do sexo comprado, o qual é intrinsecamente ligado ao sistema de heterossexualidade
e ao poder masculino que representa a absoluta corporificação do privilégio do
patriarcado masculino. (SCOULAR, 2010, p. 344).

O feminismo radical considera a prostituta como símbolo da subordinação sexual, social e econômica da mulher na nossa sociedade. O seu status é a unidade básica em relação à qual o valor de todas as mulheres é mensurado, e ao qual todas podem ser rebaixadas, a depender das circunstâncias. A prostituição, nesses termos, contribuiria para a reificação da mulher, e a sua redução ao papel de escrava sexual.

Assim, "toda prostituição seria uma forma de violação dos direitos humanos das mulheres, havendo uma falsa distinção entre prostituição forçada e prostituição voluntária". ${ }^{184}$

\footnotetext{
184 "An understanding of prostitution as a practice that contributes to women's oppression, and as foundational idea that predetermines it, informs the contemporary campaigns by radical feminist in the political and legal arenas to establish all prostitution as a violation of women's human rights, thus exploding the false distinction between forced and voluntary prostitution”. (SCOULAR, 2010, p. 344). Tradução livre: Uma compreensão da prostituição como uma prática que contribui
} 
Entende-se, nesse caso, que a prostituição somente seria exercida por necessidades econômicas ou por problemas ou traumas psicológicos, nunca por vontade livre.

Observe-se que as feministas radicais contrapõem ainda o sexo decorrente de uma relação prévia de afeto ao sexo pago. Ponderam que, enquanto o primeiro resulta de uma valorização bilateral dos envolvidos, o segundo se dá no contexto de uma relação unilateral e reificadora, em que a mulher é reduzida à posição subalterna de mercadoria (SCOULAR, 2010, p. 345). Assim, somente a primeira modalidade de relação sexual seria efetivamente "legítima".

Outro argumento trazido pelas feministas radicais é que, na prostituição, o controle do corpo passa da mulher para o comprador que se torna o seu possuidor dentro dos limites do contrato estabelecido. Tal situação, na medida em que ela se repete no tempo, teria um importante impacto na percepção da prostituta sobre si mesma, em especial no que tange à forma como ela vivencia o seu corpo. Essa vivência passa a de distanciamento da prostituta em relação ao próprio corpo, que é visto pelos outros como objeto, e cuja função é dar prazer sexual para o homem. Segundo essa perspectiva, essa visão, por fim, seria adotada pela própria prostituta. Isso teria um relevante impacto sobre o senso de identidade da prostituta, em razão do vínculo estreito entre o corpo e o eu (COY, 2009, p. 66-67). Ou seja, a prostituição seria um risco à integridade subjetiva da própria prostituta, o que, para essas teorias, reforçaria a sua nocividade.

Esse entendimento nos remete à fala de Marcos, apresentada no Capítulo 4, sobre a sua relação com a prostituição. Ele fala nas prostitutas como um "brinquedo", e destaca que, ao menos para ele, um dos principais atrativos da prostituição é o poder de ter outra pessoa a sua disposição, sem que esteja em jogo qualquer afeto. Assim, ele ecoa o entendimento das feministas radicais de que a prostituição reduz a mulher a uma máquina sexual à disposição do homem.

Por sua vez, a ideia de que a sua atividade levaria à disjunção entre a prostituta e seu corpo encontrou, em alguma medida, eco na fala de Flora, prostituta que se relacionou, durante 3 anos, com o cliente João. Segundo ela, a vida dela era "difícil”, pois, no programa: "respondia que não era "fácil", pois: "estou mostrando uma coisa aqui, e não estou sentindo isso, estou mostrando algo que não sou".

para a opressão das mulheres, e como ideia fundacional que determina e informa as campanhas contemporâneas das feministas radicais nas arenas políticas e legais, para estabelecer toda a prostituição como uma violação dos direitos humanos das mulheres, explodindo assim a falsa distinção entre prostituição forçada e voluntária. 
No entanto, o feminismo radical desconsidera que, entre as mulheres que se dedicam à prostituição, existe uma grande diversidade de histórias e motivos. Reduz tudo isso à funcionalidade da prostituição dentro de um contexto de dominação masculina. Elas trabalham com um tipo ideal de mulher, no qual não há espaço para a prostituição. Adotam assim um procedimento muito semelhante à construção vitoriana da "mulher honesta". Essa posição se aproxima bastante daquela das "igualitaristas", que partem da ideia de dominação para construir a sua ideia de mulher, e renegam como perniciosa qualquer tipo de diferenciação entre elas, conforme abordado anteriormente.

Ademais, a perspectiva das feministas radicais sobre a prostituição reduz por completo o poder de agência de suas praticantes, as quais não teriam, sequer, liberdade de expressão, utilização e significação de seu próprio corpo. Tal abordagem possui ainda um forte componente normativo, na medida em que somente seria "legítima" a relação sexual que for mantida no contexto de uma relação de afeto, o que não seria o caso da prostituição.

São essas críticas que constituem o ponto de partida para a concepção sobre a prostituição trazida pelo feminismo liberal ou pós-moderno. Segundo as integrantes dessa corrente, longe de reforçar a dominação masculina, a prostituição possui um aspecto de rebeldia e enfrentamento do poder patriarcal, com a sua visão normativa de como a mulher deve agir e falar. Cada época tem a sua concepção de "mulher honesta", e a prostituta seria uma subversão dessa figura. Nesse sentido, Gabriela Leite, importante militante do movimento feminista em favor dos direitos das prostitutas, ressalta bem essa ideia, esclarecendo:

Entrei na prostituição por rebeldia e desobediência à regra geral das coisas. Hoje, demonstro essa mesma rebeldia e desobediência, quando digo que gosto do trabalho de prostituta. Pago um preço por isso, um preço sério e pessoal, no meu dia-a-dia. Quando me apresentam como ex-prostituta, imediatamente corrijo, dizendo que sou prostituta de coração. As pessoas adoram me chamar de ex-prostituta, chega a ser um cacoete social, e eu sempre tenho que corrigir isso. Há questões clássicas em relação a mim, e que eu percebo rapidamente: me chamar de ex-prostituta; dizer que sou uma mulher que deu certo; e perguntar-me: 'Se você gosta tanto de ser prostituta, por que saiu? Gosto de responder a cada uma delas. Ex-prostituta eu não sou e nunca vou ser. Como um arquiteto deixa de ser arquiteto, um médico nunca deixa de ser um médico, mesmo trabalhando em outra atividade sempre vou ser prostituta. O referencial permanece, e o da prostituição é muito amplo. Meu namorado às vezes diz que eu penso como puta. E tem razão. Minha cultura é de prostituta. (GABRIELA LEITE, 1992, p. 18/19). 
Essa abordagem reconhece o poder de agência da mulher. Sustentar que toda relação sexual só existe para a satisfação masculina, é negar a realidade do prazer sexual feminino. Assim, a prostituição seria não apenas uma forma da mulher alcançar a autonomia econômica (o que é uma forma de empoderamento), mas também de expressão de sua sexualidade. Ao elevar a prostituta a símbolo maior da dominação masculina, as feministas radicais reduzem, em larga medida, todas as mulheres a uma máquina sexual.

Com efeito, o feminismo liberal surgiu como uma resposta, um ato de resistência das próprias prostitutas às narrativas que as colocavam como meras vítimas da dominação masculina, como fazia a perspectiva trazida pelas feministas radicais, que era então hegemônica no campo intelectual feminista (SCOULAR, 2010, p. 347). Essas prostitutas militantes passaram a combater a discriminação legal, e a batalhar pelo reconhecimento da prostituição como um trabalho como outro qualquer.

O feminismo liberal reconhece a pluralidade de histórias possíveis no âmbito da prostituição. Algumas mulheres passam a trabalhar como prostitutas por sobrevivência, outras, porque era a opção mais lucrativa que tinha disponível, e um terceiro grupo, em razão de gostar da atividade. Algumas são oprimidas por um cafetão, e outras são autônomas. Algumas aproveitam o dinheiro obtido com a prostituição para comprar a casa própria para a mãe ou pagar um curso universitário e conseguir um diploma de nível superior, outras, para curtir a vida intensamente. Algumas escondem a sua atividade de família e amigos, e outras não escondem a natureza do seu trabalho sequer de namorados e filhos. Em suma, são vários caminhos que levam uma mulher à prostituição, assim como são várias as formas com que elas vivem com essa situação. E essa riqueza não poderia ser reduzida à eventual função simbólica que a prostituição ocupe no mecanismo de dominação masculina, ou mesmo ser ignorada em favor da "luta política".

Deve ser problematizada ainda a relação entre a prostituta e seu corpo, que é apresentada pelo feminismo radical como uma relação de alienação, de distanciamento emocional, marcada por sensação de perda de controle sobre ele, que passa a ser vivenciado predominantemente como um objeto de satisfação sexual masculina. Todavia, há prostitutas que não vivenciam dessa forma a relação com o seu corpo. Essas prostitutas sentem um forte senso de empoderamento e de domínio sobre ele. Orgulham-se do seu poder de atrair homens e os satisfazer com os seus corpos, como uma "deusa do sexo" (COY, 2009, p. 72). Para elas, o corpo não é um objeto, uma fonte apenas de experiências negativas, mas algo que a mulher pode se apropriar para tornar possíveis escolhas produtivas e valiosas. 
Em resposta, as feministas radicais afirmam que essa figura da prostituta empoderada é possível apenas por conta da forma como a indústria cultural contemporânea retrata a mulher, celebrando o seu papel como objeto sexual (COY, 2009, p. 73). Ou seja, elas enxergam mesmo na prostituta empoderada uma manifestação da dominação masculina.

Contudo, essa narrativa de empoderamento das trabalhadoras sexuais repete-se também em lugares onde a cultura é ainda muito conservadora e a dominação masculina assume contornos mais tradicionais, ou seja, em lugares onde não existe essa celebração da mulher como objeto sexual. É o que demonstra a pesquisa desenvolvida por Seshu e Pai (2014), comparando as narrativas e as vivências de dois grupos de mulheres que vivem na zona rural da Índia. Um desses grupos era filiado a uma cooperativa de trabalho de trabalhadoras comuns, e o outro, a uma cooperativa de trabalho de prostitutas. Contrastando-se a narrativa de vida das mulheres de um e do outro grupo (SESHU e PAI, 2014, p. 47-48), percebe-se claramente um maior senso de empoderamento por parte das prostitutas, o que não surpreende, tendo em vista aos rígidos e tradicionais padrões de dominação masculina presentes na Índia.

Mostra-se interessante aqui retratar a fala dessas prostitutas indianas. Elas se consideram no controle da dinâmica do bordel, onde são os clientes que estão submetidos às suas regras. Valorizam o fato de poderem ter vários amantes (que chamam de malaks), inclusive ao mesmo tempo, e esse relacionamento apresenta algumas características relevantes: quando se inicia a convivência, é o homem que se muda para a casa da mulher; mesmo no curso do relacionamento, o amante precisa pagar para manter relações sexuais com a prostituta, pois elas consideram reprovável manter relação sexual sem uma contraprestação; os filhos pertencem à mãe, e o papel de pai é exercido pelo amante que, naquele momento, morar com ela, mesmo que não seja o seu pai biológico. Preocupam-se, ademais, em manter, a todo o momento, a sua autonomia emocional e financeira (SESHU e PAI, 2014, p. 47-48)

Naturalmente, essas narrativas são trazidas por prostitutas especialmente empoderadas, pois participam de uma cooperativa de trabalho em que elas mesmas gerenciam o seu trabalho. Contudo, elas indicam a existência de múltiplas possibilidades de vivência da prostituição, para além da visão defendida pelas feministas radicais. Observa-se ainda que as referidas narrativas de liberdade devem ser localizadas no contexto indiano, no qual a prostituta é vítima de um fortíssimo estigma, que dificulta inclusive o seu acesso a direitos básicos, como saúde e educação (SESHU e PAI, 2014, p. 51). Com efeito, a cultura indiana carrega um forte desprezo pela mulher em geral, o que explica, ao menos em parte, o fato de ter um dos maiores índices de tráfico de mulheres no mundo (ACERO, 2011, p. 134). 
A questão parece residir no fato de as feministas radicais partirem das características de determinado tipo de prostituição nas sociedades capitalistas ocidentais, para extrair conclusões universais e essencializadas (SHRAGE, 2016, p. 566). O fato de a prostituição se relacionar de determinada forma com a desigualdade de gênero, raça, classe e idade em um espaço social específico, não significa que, em outro, ela assuma as mesmas características. Há lugares no mundo em que a prostituição não se importa com o gênero, mas apenas com a raça e com a classe social, e outros em que a classe social ou a raça não são importantes, mas apenas o gênero (SHRAGE, 2016, p. 566-567).

Ademais, Acero considera, com base nos trabalhos de Rudio, que:

há uma relação direta entre as tendências da libertação das mulheres, entendido como seu acesso ao mercado de trabalho, e o crescimento do exercício do trabalho sexual, o que viola a suposição tradicional de que a falta de renda seria fator determinante para o exercício de tal trabalho". Assim, Acero conclui que "essa tendência ocorre principalmente em países onde a liberação feminina ou a entrada das mulheres no mercado de trabalho teve mais força, pelo que se poderia entender o trabalho sexual como uma manifestação da liberação feminina, na medida em que essa fonte de renda permite à mulher se livrar da dependência econômica, sendo o corpo, dessa forma, um instrumento político de reivindicação, apesar dos debates feministas de corte marxista, que entendem a prostituição como uma nova forma de escravidão (ACERO, 2011, p. 133).

No Capítulo 3, vimos que parte das prostitutas entrevistadas indicaram que a prostituição não era a sua única opção de trabalho, mas era a mais rentável do ponto de vista econômica. Sem dúvida, essas opções não seriam muitas, mas existiam, tanto que algumas delas trocaram um emprego formal, ganhando o salário mínimo, pelo trabalho de prostituição. E essa é a percepção mesmo entre as prostitutas de rua, que, no conjunto das prostitutas, ocupa o ponto mais baixo na escala da remuneração, atrás das prostitutas que conseguem a maior parte de sua clientela por meio de sites ou por meio de books apesentados aos clientes a agenciadores.

Segundo os clientes cujas entrevistas foram apresentadas no Capítulo 4, parte dessas prostitutas de sites e de books são filhas da classe média, e têm as suas necessidades básicas inteiramente atendidas por suas famílias. Ora, adotando-se a perspectiva das feministas radicais, como explicar a existência de mulheres que se dedicam à prostituição, apesar de existir outras opções econômicas disponíveis? Nessa perspectiva, se elas não podem ser tidas como miseráveis, só poderiam ser classificadas como loucas. 
Em resumo, na sua análise da prostituição, as feministas radicais consideram a prostituição como um fenômeno monolítico, sem variações mais relevantes, em que predomina a categoria de dominação masculina. Por outro lado, as feministas liberais reconhecem que a vivência da prostituição é múltipla, e não pode ser reduzida à condição de vítima, e essa diferença deve ser respeitada. Nessa linha, seria uma ficção tratar a prostituição como um fenômeno transcultural, ou seja, com um único significado em todas as culturas existentes (SHRAGE, 2016, p. 569). Cada uma dessas posições traz projetos político-sociais radicalmente diferentes, em especial no que concerne ao trabalho das prostitutas e a sua regulamentação.

Com efeito, nessa dicotomia entre a vitimização e a rebeldia, há duas figuras polarizadas sobre o imaginário da prostituta, a femme fatale e a meretriz vitimada pelas condições econômicas adversas, com o destino implacável da exploração de seu corpo pelo masculino (RAGO, 1992, p.21) ${ }^{185}$.

Outro aspecto interessante a considerar é a valoração da relação entre a prostituição e a subjetividade das prostitutas. Por exemplo, enquanto as feministas radicais pensam que a prostituição é fundamentalmente um erro por violar a subjetividade da prostituta ao tratá-la como uma mercadoria, as feministas liberais entendem que a prostituição é fundamentalmente certa porque ela proporciona aos clientes um acesso ao que elas têm de mais verdadeiro, preenchendo suas necessidades humanas (CONNEL \& DAVIDSON, 2002, p. 90). ${ }^{186}$

\footnotetext{
185 “As figuras polarizadas da prostituta que emergem na documentação - de um lado, a meretriz vitimizada pelas condições econômicas adversas e por um destino implacável; de outro, a femme fatale, que embora não seja originariamente prostituta, é frequentemente associada a ela para designar a cortesã poderosa e cruel - correspondem a dois tipos de explicação que os estudos sobre prostituição apresentam. Mais frequentemente, a análise parte para uma explicação essencialmente econômica da comercialização sexual do corpo feminino: a mulher se prostitui para complementar o salário miserável ou porque não tem qualificação profissional - campo de atuação da prostituta-vítima. Ou então se trata nas análises psicologizantes de algum caso patológico: traumas de infância, complexos edipianos mal resolvidos, sexualidades exuberantes. Aí entra em cena a mulher-aranha. (MARGARETH RAGO, 1991, p. 21).

${ }^{186}$ Há, inclusive, quem advogue uma função social da prostituição, quando as prostitutas podem oferecer sexo pago a pessoas que não possuem chances de consegui-lo por meio dos mecanismos usuais de cortejo e conquista, como doentes terminais, deficientes físicos e pessoas muito tímidas. Como se viu no Capítulo 4, essa funcionalidade foi mencionada na fala de policiais militares, como sendo algo que eles observam no seu dia-a-dia na W3 norte. "There will always be people who don't have the charm or social skill to woo a partner. In a society where mutual attraction and sexual reciprocity are the normal bases for bonding, what would happen to the unattractive people, those without the ability or interest to give as good as they get? Disabled people, folks with chronic or terminal illnesses, the elderly, and the sexually dysfunctional would continue to benefit (as they do now) from the ministrations of skilled sex workers who do not discriminate against these populations" (CONNEL \& DAVIDSON, 2002, p. 89). Tradução livre: "Sempre haverá pessoas que não têm o charme ou habilidade social para atrair um parceiro. Em uma sociedade onde atração mútua e reciprocidade sexual são a base para a criação de vínculos, o que aconteceria com as pessoas pouco atraentes, aqueles sem a habilidade ou o interesse de dar tão bem quanto recebe? Pessoas com deficiência, pessoas com doenças crônicas ou terminais, os idosos e os sexualmente disfuncionais continuariam a beneficiar (como o fazem agora) dos serviços dos trabalhadores do sexo qualificados que não discriminam contra esse grupo de pessoas". Nesse sentido, há, ao menos na Alemanha, prostitutas que se especializam em atender pessoas com deficiências graves, como no caso relatado na reportagem da revista alemã chamada "Bento", que pode ser encontrada no seguinte link: http://www.bento.de/gefuehle/sexualbegleitung-edith-arnold-hilft-menschen-mit-behinderung-beim-sex-

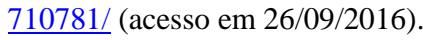


Naturalmente é importante ressaltar que, como já mencionado, embora seja possível identificar a oposição de posições extremas sobre a valoração da prostituição no campo intelectual feminista, há também uma gradação de posições. Por exemplo, as "pragmáticas" não desenvolvem valoração moral em relação ao tema, mas acreditam que leis criminalizantes da atividade (tanto para as prostitutas quanto para os clientes) são impraticáveis e, portanto, a política deve ser direcionada ao fomento do mercado de trabalho. As feministas pragmáticas estão mais presentes na Holanda e alguns dos países europeus que buscam a descriminalização da atividade, a legalização ou a regulação do mercado do sexo (EDWARDS, 1997, p. 78). Há também grupos de feministas apresentam uma repugnância moral à prostituição e utilizam argumentos morais para combatê-la. Por fim, há aquelas que vêm a prostituição como uma forma de violência direta contra a mulher, cujo combate deve ser promovido pela legislação penal a fim de proibir por completo a atividade (GOULD, 2001, p. 438).

Nesses termos, é possível dizer que as perspectivas das feministas radicais e das feministas liberais resgatam, respectivamente, a disputa no campo intelectual feminino entre igualitaristas e diferencialistas. Esses dois conjuntos de posições e contraposições remontam a diferentes relações entre as ideias de dominação e a diferença.

As igualitaristas e as feministas radicais enxergam na diferença um mecanismo de reforço da dominação masculina, e, portanto, elas devem ser rechaçadas ou, no caso da prostituta, ativamente combatidas. Já o pensamento das diferencialistas e das feministas liberais considera importante o reconhecimento e a valorização das diferenças, seja entre mulheres e homens ou ainda entre prostitutas e não prostitutas Para elas, tal valorização não conduz necessariamente ao reforço da dominação masculina, sendo possível alcançar a igualdade político-social entre esses grupos sem que a identidade específica de cada um seja dissolvida numa ideia amorfa de universal.

Tanto a posição das igualitaristas quanto a das feministas radicais naturalizam a relação de fatores, que, na realidade, ocorre de forma incidental. Por um lado, as igualitaristas consideram que o reconhecimento da diferença entre os sexos conduz necessariamente ao reforço da dominação masculina, e, por outro, as feministas radicais consideram que o comércio do sexo tem como consequência inevitável a reificação de todas as mulheres. Todavia, quando se percebe que a relação entre esses fatores é tanto incidental quanto socialmente construída, percebe-se o caráter histórico e, portanto, reversível dessas relações. Assim, é perfeitamente possível imaginar um arranjo cultural em que se reconheça a diferença 
entre os sexos ou ainda a prostituição como um trabalho como qualquer outro, sem que isso implique um reforço da dominação masculina.

Ora, se inexiste essa relação necessária, o problema não é a prostituição ou a diferença entre os sexos, mas sim as construções sociais que tornam esses fatores funcionais para a dominação masculina. Nesse caso, o enfrentamento dos problemas apontados pela teoria feminista parece exigir um conjunto de estratégias distintas daquelas apontadas pelas igualitaristas e feministas radicais, que deverá passar pela revisão dos referidos construtos sociais, em especial das ideias de sexualidade e identidade sexual em nossa cultura.

Em suma, é possível afirmar que a disputa acerca do significado da prostituição dentro do campo intelectual feminista reflete a divisão mais ampla do campo entre igualitaristas e diferencialista, com a mobilização de um conjunto similar de elementos discursivos.

\section{Mas é no "campo de batalha" que têm voz as putas da W3 norte}

Se, como visto, o campo intelectual feminista, como todos os campos, constitui um espaço para lutas e disputas por influência ou capital específico, quando o assunto é prostituição, a disputa está na atribuição de significado para a atividade. Resta então, no contexto de presente trabalho, buscar, no campo de "batalha"187 da W3 norte e nas representações sociais das próprias prostitutas, o que elas dizem, as putas, sujeitos da nossa investigação, e como essas falas relacionam-se com a narrativa trazida pela academia.

De acordo com as representações sociais acerca da prostituição na W3 norte, pelas 10 entrevistadas já apresentadas no Capítulo 3 (Anexo 2), é possível notar que a fala dessas prostitutas aproxima-se das feministas liberais. Aliás, partindo da perspectiva das entrevistas, é possível contraditar muitos dos argumentos mobilizados pelas feministas radicais para fundamentar a sua posição.

Inicialmente, ressalta-se que o ponto central da doxa do campo intelectual feminista é a consideração prévia de que existe uma dominação do masculino sobre o feminino, a qual deve ser superada. Contudo, as posições no campo divergem acerca de como se dá essa superação.

Nesse contexto, considerando que as igualitaristas sustentam a prostituição como o ápice da dominação masculina sobre a mulher, por objetivá-la e reduzi-la a simples

\footnotetext{
${ }^{187}$ Ressalte-se que "batalhar" é uma categoria nativa, sinônimo de prostituir-se e que foi incorporada na CBO 5198-05, no item III, A, como uma das áreas de atividades da prostituição - Batalhar programa. "III - Áreas de atividades: A - Batalhar programa; B - Minimizar as vulnerabilidades; C - Atender Clientes; D - Acompanhar Clientes; E - Administrar orçamentos; F - Promover a organização da categoria; G - Realizar ações educativas no campo da sexualidade."
} 
mercadoria, verifica-se que as entrevistadas rechaçaram a ideia de que se sentem como objetos e de que seus direitos humanos são violados na prática da atividade de prostituição.

Tal rejeição da narrativa do feminismo radical pode ser observada, por exemplo, quando, diante da pergunta "Você se sente como um objeto dos seus clientes na sua atividade de prostituição?", Mônica me respondeu com uma nova pergunta: "Você se sente objeto quando você dá de graça?". Por outro lado, diante da mesma questão, Letícia, Renata, Carol e Priscilla responderam que quem seria objeto seriam as "piriguetes", referindo-se às mulheres que mantém relação sexual com os homens em troca de presentes caros e jantares. Diante disso, nas entrevistas com as prostitutas, apresentadas no Capítulo 3, percebi que elas têm muito claro para si, que estão ali por uma opção, a melhor entre as disponíveis, e, portanto, que têm sim poder decisão por sua vida. Buscam ainda ressaltar as nuances do seu trabalho, como a sua atuação como psicólogas, de modo a indicar que não são um mero objeto na mão dos seus clientes.

Ademais, nessas entrevistas, nada indicou que qualquer dessas prostitutas fosse portadora de qualquer grave distúrbio psicológico, que justificasse o seu engajamento na prostituição. Isso é importante porque, para as feministas igualitaristas, seria falsa a distinção entre prostituição voluntária e prostituição forçada, uma vez que todas as prostitutas ou têm traumas psicológicos ou necessidades econômicas. Como se viu, isso não se confirmou nessas entrevistas.

Naturalmente, momentos de tristeza e solidão foram narrados pelas entrevistadas, como foi o caso de Priscilla que disse que, nas madrugadas, a pista é muito fria, não há muitas pessoas para conversar e ela se sente só. Além disso, Mônica, a que se intitulou de "brava" e era também bastante articulada, disse que a vida na prostituição não era fácil e que ela tinha projetos de deixá-la. Contudo, apesar de quase todas as garotas de programa me dizerem ter um plano para um futuro sem a prostituição, mesmo porque algumas já reconheceram que sua juventude tem limitação temporal, elas não me pareceram pelo menos aos olhos de uma pesquisadora das Ciências Sociais, com sintomas de depressão ou profunda tristeza. Ao contrário, o clima das entrevistas foi bastante leve e elas me narravam fatos tanto engraçados quanto tristes, como há em qualquer atividade profissional.

Ademais, apesar de elas possuírem, por óbvio, necessidades financeiras, elas me pareceram plenamente autônomas, com relevante poder de agência, e algumas até de planejamento, em ter escolhido a prostituição como melhor opção entre aquelas disponíveis para garantirem seus luxos, como disse Renata, desejos de melhoria de vida, segundo Letícia, Vanessa, Mônica, Layane, Su, ou pagar a faculdade, no caso de Carol e também Mônica. 
Vanessa disse que já estava próxima de seu objetivo, pois construíra uma casa em Águas Lindas, cidade do entorno de Brasília, para sua mãe, e já teria um bom dinheiro guardado para abrir um restaurante com o marido. Letícia, por sua vez, disse que vai deixar a prostituição, mas planeja uma ação definitiva e, por isso, ela está intensificando os programas para guardar um bom dinheiro.

Verifiquei, assim, planejamentos financeiros de vida como o de qualquer pessoa da minha convivência que não exerce a atividade de prostituição, não se mostrando as necessidades financeiras das entrevistadas algo diferente da vida de qualquer brasileiro em situação de crise econômica. Basta lembrar a história de Priscilla que trabalhava oito horas por dia em uma padaria e que recebia um salário mínimo ( $\mathrm{R} \$ 880,00$, ao tempo da entrevista). Na prostituição, Priscilla disse auferir cerca de R \$ 4.000,00 mensais, além de ter flexibilidade de horários.

Também não se mostrou presente, na fala das prostitutas, a ideia de objetivação de seus corpos, ou ainda o sentimento, por parte delas, de alienação do próprio corpo, nos moldes acima descritos. Pela descrição da atividade na prostituição, elas disseram que não se trata de "venda do corpo", porque, afinal, como lembrou Priscilla, o "corpo é meu", mas sim de prestação de serviços que envolvem muito mais que atividades sexuais. Há também as fantasias eróticas, como bem detalhou Mônica, Bia, Priscilla e $\mathrm{Su}$, e ainda o suporte psicológico sexual aos clientes, segundo o depoimento unânime de todas as entrevistadas, que ressaltaram que se sentem às vezes mais como psicólogas do que como prostitutas.

Interessante notar que essa narrativa trazida pelas prostitutas entrevistadas se contrapõe àquela outra que coloca a prostituição como a mais baixa das atividades, e que a mulher somente se recorreria a ela, a tal "venda do corpo" quando não lhe restasse qualquer outra opção, a fim de assegurar a sua subsistência. É assim uma importante ressignificação das representações sociais que rodeiam a atividade de prostituição.

Além disso, partindo da concepção do corpo como processo político (GROSZ, 2000, p. 84), já descrita na introdução, é possível afirmar que essas narrativas trazidas pelas prostitutas da W3 norte possibilitam uma ressignificação do próprio corpo nos termos já propostos por Guimarães e Merchán-Hamman, em uma pesquisa sobre as prostitutas no Rio Grande do Sul, que tem uma abordagem muito similar ao presente trabalho:

Uma das fortes representações sociais relacionadas à prostituição e à prostituta, no senso comum de nossa sociedade, encontra-se vinculada à imagem da mulher que está presente em um espaço marginal reservado à continência dos desejos sexuais masculinos, livrando as moças de 'boa família' da voraz realização das necessidades 
biológicas dos homens. Durante muitos anos, a tolerância da prostituição como um 'mal necessário' determinou a forma pela qual as prostitutas se reconheciam no campo social. A imagem predominante, nesse sentido, era aquela que a tornava a mulher que vendia seu corpo no intuito de satisfazer as luxúrias masculinas que não podiam ser realizadas no espaço da relação conjugal, ou mesmo antes do casamento. No entanto, foi observado nos grupos focais que a representação social de uma mulher que vende o corpo para a sua sobrevivência vem sendo, em certo sentido, deslocada e ressignificada, por ela, para novas interpretações sobre o erotismo presente na prostituição. Nesse contexto, pode-se perceber que a ideia da realização de fantasias eróticas, bem como de diferentes jogos sexuais que não se restringem à prática sexual convencional, vem se revelando como a razão da busca de muitos dos clientes pelo comércio de fantasias.

'Eu acho que essa coisa de dizer que a gente vende o corpo é uma bobagem. Meu corpo está aqui comigo. E cuido muito bem dele. A gente está aqui para vender fantasia, ilusão. Muitas vezes, tem uns clientes que nem querem nada, só conversar. E a gente conversa. Tem muita coisa misturada nessa coisa da prostituição. É só a gente não aceitar dizer essas coisas da gente. Isso é o que todo mundo pensa, mas ninguém na verdade sabe de nada. Eu não aceito isso não. (GUIMARÃES e MERCHÁN-HAMANN, 2005, p. 533).

A representação social da diferença entre venda de sexo e venda de pessoa ou do corpo é muito bem retratada pela entrevista supracitada, na qual a prostituta ressaltou que ela vende fantasias, ilusão e desejo, ideias extremamente comercializáveis, principalmente, no contexto do fetiche da economia capitalista. Afinal, como definiu Marx, "a mercadoria, é, antes de mais nada, um objeto externo, uma coisa, que por suas propriedades, satisfaz necessidades humanas, seja qual for a natureza, a origem delas, provenham do estômago ou da fantasia" (MARX, 1996, p. 41).

Nesse sentido, a narrativa da objetivação da prostituta pode apresentar-se como um obstáculo à melhoria das condições de trabalho para aquelas que vêm na prostituição, a melhor escolha entre outras ocupações e meios de subsistência, os quais elas mesmas julgam serem inferiores. Assim, a postura de animosidade em relação à prostituição mostra-se incoerente com a defesa dos direitos das mulheres, pois impossibilita o exercício de um dos poucos direitos que essas mulheres possuem: o direito de escolha. Nesse sentido, também argumentam Blanchette, Silva e Camargo:

É nossa contenção que o (ab)uso do conceito de objetificação dentro do debate sobre o trabalho sexual tem contribuído para uma situação em que a transformação do indivíduo em objeto está geralmente visível somente no contexto dos trabalhos estigmatizados, como a prostituição, a produção de pornografia ou a dança erótica. 
Todavia, como Marx, Durkheim e Simmel (entre muitos outros sociólogos) reconheceram, a divisão do trabalho, a monetarização da sociedade e a urbanização tendem a objetificar o trabalho em geral e, através disso, instrumentalizar as relações sociais. Nesse contexto, o trabalho sexual pode aparecer como uma alternativa que oferece aos trabalhadores uma notável melhoria tanto nas condições da labuta, quanto na possiblidade de exercer sua agência individual dentro do local de trabalho. Em outras palavras, o trabalho sexual, longe de ser objetificante, pode ser relativamente libertador, ao potencializar a manipulação simbólica e a expressão da individualidade por parte de seus praticantes (BLANCHETTE, SILVA e CAMARGO, 2014, p. 147).

Convém lembrar, inclusive, que esse movimento de ressignificação da prostituição, a partir da narrativa de valorização da atividade como uma profissão ou um trabalho que merece respeito como qualquer outro, não partiu das torres de marfim das Universidades, mas do movimento das próprias prostitutas. Em 1989, ocorreu nos Estados Unidos, o primeiro “Congresso de Putas”, "organizado não apenas para lutar contra a discriminação, mas também para resistir às narrativas que as apresentavam como meras vítimas" (SCOULAR, 2004) ${ }^{188}$.

Vale lembrar que a história também mostra um "atraso cognitivo" por parte do mundo acadêmico em tratar os direitos das mulheres no campo científico muito tempo depois que elas já haviam conquistado o direito de voto na primeira onda do feminismo, como visto acima.

Em suma, as entrevistas realizadas puderam indicar uma tendência interessante de novas significações e interpretações para a ideia de corpo e do mercado do sexo e da fantasia, ideias essas produzidas pelas próprias protagonistas da atividade de prostituição, da pista, do chão, e

\footnotetext{
${ }^{188}$ This tension, is vividly captured in Gail Pheterson's accounts of the first Congress of Whores (in 1989) where, describing themselves as 'feminists in exile' (Pheterson, 1989: 17), prostitutes organized not only to campaign against legal discrimination but also to resist accounts which cast them as mere victims. Pheterson highlights the beginnings of counter movements of 'sex workers' in the West which formed directly in response to legal discrimination but also in response to feminist hesitations around viewing prostitution as work (Bell, 1987; Delacoste and Alexander, 1988). In A Vindication of the Rights of Whores, Pheterson (1989) subverts Wollstonecraft's early liberal feminist manifesto to ground an ongoing campaign for the civil rights of women in the sex industry. Seemingly flippant at times, for example, the demand for the right 'to charge for what other women give for free' (Delacoste and Alexander, 1988: 273), sex worker narratives do offer important counter-hegemonic insights: 'it's open challenge both to the identification of sex acts with acts of desire and to the opposition between erotic/affective activity and economic life' (Zatz, 1997: 277). (SCOULAR, 2004). Tradução livre: Esta tensão é vividamente capturados nos relatos de Gail Pheterson sobre o primeiro Congresso de "Putas" (em 1989), onde, descrevendo-se como "feministas no exílio" (Pheterson, 1989: 17), prostitutas organizaram não só para a campanha contra a discriminação legal, mas também para resistir a narrativas que as retratam como meras vítimas. Pheterson destaca o início de contra movimentos de 'trabalhadoras do sexo' no Ocidente se formaram diretamente em resposta à discriminação legal, mas também em resposta às hesitações feministas em tratar a prostituição como trabalho (Bell, 1987; Delacoste e Alexander, 1988). Em "Uma Vindicação dos Direitos das 'Putas'", Pheterson (1989) subverte o manifesto feminista liberal de Wollstonecraft, para embasar uma campanha em curso pelos direitos civis das mulheres na indústria do sexo. Aparentemente irreverente às vezes, ela demanda, por exemplo, o direito "para cobrar o que outras mulheres dão de graça" (Delacoste e Alexander, 1988: 273), as narrativas das profissionais do sexo realmente oferecem importantes ideias contra hegemônicas: "é um desafio aberto tanto à identificação de atos sexuais com atos de desejo e à oposição entre a atividade erótica / afetiva e vida econômica "(Zatz, 1997: 277) (SCOULAR, 2004).
} 
não por filósofos nefelibatas, projetistas de ideias utópicas. Estratégias concretas para equacionar desafios práticos, em busca de um ganho de qualidade de vida atual e não prospectivo ou geracional.

Naturalmente, como já observado pelas próprias entrevistadas, a prostituição não seria alternativa, para a maioria das mulheres, para uma vida abastada e cheia de oportunidades. Essa vida simplesmente não está disponível para qualquer delas. Mas ela é, ainda, de certa maneira, resultado de uma escolha livre e individual. Retirar esse direito de escolha de qualquer ser humano é quebrar a regra do imperativo categórico de Kant (2002, p. 59) ${ }^{189}$, tratar seres como meio de atenderem a posições ideológicas próprias e não como fins em si mesmo.

\section{Notas para um dispositivo acadêmico da prostituição na W3 norte}

Ao fim desse capítulo, ressaltei a importância de haver maior e melhor comunicação entre o campo acadêmico e os demais campos de exercício de poder social. Como visto, a diferenciação entre as feministas radicais e as igualitaristas, de um lado, e o feminismo liberal e as diferencialistas, de outro, traz consequências que extrapolam o próprio campo intelectual feminista, alcançando a vida concreta das prostitutas.

A partir das entrevistas realizadas, pode-se verificar um grande distanciamento entre, por um lado, as prostitutas, que enxergam na sua atividade profissional o melhor caminho entre as opções disponíveis no momento para crescimento financeiro e social, e, de outro, as integrantes do ramo igualitarista do campo intelectual feminista, que advogam, de forma radical, contra a atividade de prostituição, de forma até a impossibilitar esse exercício de direito de escolha dessas mulheres.

A adoção de uma ou outra posição repercute diretamente na esfera política, na medida em que cada uma conduz a uma estratégia diferente de enfrentamento à dominação masculina. O grupo que prevalecer na disputa interna dentro do campo intelectual feminista, mediante o contínuo acúmulo de capital específico, terá uma maior autoridade para levar adiante o seu projeto na arena política. Observa-se a repercussão, no campo do poder, desse domínio de um ou outro grupo do campo intelectual feminista, e o seu grau de influência dependerá da taxa de câmbio estabelecida entre o capital específico e o poder político em sentido amplo. Essa

\footnotetext{
189 "Age de tal modo que possas usar a humanidade, tanto em tua pessoa como uma pessoa de qualquer outro, sempre como um fim ao mesmo tempo e nunca apenas como um meio”. (KANT, 2002, p. 59)
} 
taxa de câmbio, por sua vez, dependerá da correlação de forças no espaço social como um todo (BOURDIEU, 2008, p. 52). Daí porque a disputa entre esses grupos é tão acirrada.

Essa dinâmica é bem exemplificada pela polêmica envolvendo a regulamentação da prostituição como trabalho.

As feministas radicais opõem-se a essa regulamentação, pois ela significaria a normalização do símbolo maior da dominação masculina. A prostituta, especialmente a de rua, é retratada como uma vítima que precisa de proteção, em razão do seu perigoso estilo de vida (SANDERS, 2009, p. 511). Essa visão resultou, na Inglaterra, na transformação da prostituição de rua em infração civil ou mesmo criminal (caso haja inobservância da sanção civil), cuja penalidade é a sujeição das prostitutas a programas de reabilitação, concentrandose apenas em retirar a mulher da prostituição, e não em mitigar o estigma e a possível violência a que ela esteja submetida (SANDERS, 2009, p. 512 e 518). Redundou também na criminalização da conduta do usuário dos serviços de prostituição na Noruega, na Suécia ${ }^{190}$ e na Islândia, sendo que, na Suécia, a própria prostituição é criminalizada.

Por seu turno, as feministas liberais buscam a regulamentação do trabalho das prostitutas, como forma de torna-las menos vulneráveis, e, dessa forma, contribuir para uma maior igualdade político-social dessa categoria de mulheres. É o que se está tentando no Brasil com o Projeto Gabriela Leite, o PL 4.211/12 ${ }^{191}$. Na Colômbia, as defensoras dessa posição alcançaram uma importante vitória com a decisão T-629 de 2010 da Corte Constitucional colombiana. Nessa decisão, reconheceu-se a relação entre a prostituta e o dono do bordel como uma relação de trabalho, de modo que a demissão injustificada da primeira, no curso da gravidez, acarreta a necessidade de indenização por parte do empregador, por conta da estabilidade relativa que ela goza nesse período (ACERO, 2011, p. 139).

\footnotetext{
${ }^{190}$ Com efeito, o modelo sueco de criminalização da clientela da prostituição é baseado em três argumentos principais: "Em primeiro lugar, que o comércio do sexo está em conflito com a noção de igualdade entre homens e mulheres. Como os dois poderiam ter de igual valor em uma sociedade que permite a venda do corpo das mulheres? Em segundo lugar, em outros países europeus, como Alemanha e Holanda, onde a prostituição foi aceita, ela tem aumentado. Em terceiro lugar, os custos sociais da prostituição, em termos de doenças e criminalidade, são prejudiciais para a sociedade como um todo (tradução livre do inglês) (GOULD, 2001, 441). Ou seja, tal visão toma como pressuposta a correlação entre prostituição, de um lado, e criminalidade e doenças, de outro.

${ }^{191}$ O PL 4.211/12 é a terceira tentativa para regulamentar a prostituição no Brasil, depois de 2003, por meio do deputado federal Fernando Gabeira, e de 2006, com o deputado federal Eduardo Valverde. Atualmente, tramita na Câmara dos Deputados o PL 4.211/12, de autoria do deputado Jean Wyllys, ficou conhecido como PL Gabriela Leite, que foi prostituta, fundadora da Organização Não-Governamental - ONG Davida - Prostituição, Direitos e Saúde, instituição que defende os direitos dos profissionais do sexo. A proposta de lei sustenta a regulamentação da atividade de prostituição voluntária de pessoas de maiores de 18 anos, torna exigível juridicamente a remuneração, garante aposentadoria especial com 25 anos de contribuição, regulamenta a exploração econômica da prostituição na apropriação por terceiro de mais de $50 \%$ da renda auferida, ou pagamento algum ao profissional do sexo, e também para casos de violência e grave ameaça e estabelece modificações no Código Penal a fim de se possibilitar o exercício da prostituição em atividade associativa. A íntegra do projeto encontra-se disponível em http://www.camara.gov.br/proposicoesWeb/prop mostrarintegra?codteor=1012829 e também no Anexo 4. O referido projeto é um importante ponto de partida para a discussão do assunto, e contém dispositivos que merecem um exame mais aprofundado, como a possibilidade de apreensão, pelo cafetão ou agenciador, de até $50 \%$ da renda auferida pela prostituta.
} 
Acima de tudo, porém, é fundamental dar voz às prostitutas, as diretamente interessadas nas consequências das representações sociais acerca da sua atividade e nas disputas ideológicas e políticas em torno da regulamentação da sua profissão. Elas não podem ser silenciadas ou ignoradas simplesmente para preservar a beleza estática de uma modelo ideal de mulher, seja ele construído por uma narrativa moralista ou uma narrativa feminista. Afinal, a disputa e a luta dessas mulheres por melhores condições de vida imediata e em curto prazo se trava no campo de batalha das pistas e não somente nos bancos acadêmicos com perspectivas utópicas e geracionais, muitas vezes mais preocupado com prevalecer em seu campo de poder do que com o destino dos seus objetos de estudo. 


\section{Considerações finais}

Após a apresentação de vários aspectos sobre a prostituição feminina na W3 Norte, é chegada a hora de construir um dispositivo capaz de descrevê-la, a partir dos dados e informações colhidos ao longo da pesquisa.

O conceito de dispositivo de Foucault foi utilizado como principal chave de leitura e norteador para minhas análises. A partir dele, busquei esse "conjunto de elementos heterogêneos, composto por $\underline{\text { discursos }}$, por $\underline{\text { instituições, }}$, por arranjos de arquitetura , por decisões regulamentares, por leis, por medidas administrativas, por enunciados científicos, por proposições filantrópicas, enfim: daquilo que é dito, bem como do que não é dito" (apud RAFFNSØE, 2008).

Assim, como instituição, procurei nos dados das ocorrências criminais da Polícia Civil do Distrito Federal relacionadas diretamente com a atividade de prostituição na W3 norte, registradas nos anos de 2010-2015, bem como nas entrevistas realizadas com delegadas de polícia da DEAM, responsável pela região em questão, para entender como se daria a relação da prostituição com a criminalidade.

Naturalmente, conforme bem ressaltado, os dados apreendidos estão longe de reproduzir a realidade de maneira precisa e imediata, mesmo porque, apesar de representarem informações objetivas, sua produção depende de uma série de fatores relacionados às disposições pessoais, que vão desde a vontade de vítimas (prostitutas ou clientes) de procurarem a delegacia de polícia para proceder ao registro, a própria habilidade de a polícia militar resolver o problema no local, ao autogerenciamento do conflito pelas partes envolvidas ou o temor de buscar o Estado por medos ou mesmo por exposição de alguma condição vulnerável.

Dessa forma, os "dados", apesar de palpáveis e objetivos, constituem meros indícios de partes da realidade, são versões, que podem dizer, e também não dizer, a partir da ausência de registros. Interessante que, pelo menos pelos registros das ocorrências policiais analisadas, foi possível observar um percentual pouco significativo, pelo menos durante os anos analisados (2010-2015), de uma relação direta entre a criminalidade em torno da avenida W3 norte e a atividade de prostituição. Foram efetuados apenas 121 registros criminais que continham relação direta entre a atividade de prostituição, em um universo de 69.171 ocorrências 
policiais, do tipo criminal, ${ }^{192}$ nas $2^{\text {a }}$ DP e a DEAM. Dessa amostra, 74 registros referiram-se a crimes violentos, que tiveram as prostitutas como vítimas em 42 casos, e como autoras em 29 casos. Nos crimes patrimoniais, que tiveram 25 incidências, e nos crimes contra a ordem pública e outros, com 37 incidências, ao longo dos cinco anos estudados, as prostitutas figuraram, respectivamente, como vítima em 4 e 13 casos e como autoras em 15 e 23 casos.

A partir desses dados, verifica-se, portanto, pouca significância em termos da quantidade de notícias de crime registradas para justificar o "pânico moral" em torno da atividade de prostituição na avenida W3 norte, que se ampara exatamente na criminalidade para fundamentar ações morais como a reproduzida na faixa mencionada na epígrafe do Capítulo 2, que continha os seguintes dizeres: "amanhã nos expulsam de nossas casas e usam nossas camas" (Jornal de Brasília, 20/4/2012). Importante também notar que durante esses cinco anos, houve apenas 8 registros do crime de perturbação da tranquilidade na PCDF.

Digno de nota é a quantidade expressiva dos crimes violentos (74 em 121 incidências), entre os quais em 42 casos as prostitutas configuram como vítimas, ou seja, pouco mais de um terço do total de ocorrências consideradas. Apesar de ser a maioria nessa amostra, o número pequeno diante do grande universo de ocorrência se confirma tanto com a narrativa das próprias prostitutas, que disseram buscar, regra geral, resolver seus problemas com clientes e com a violência urbana com suas próprias estratégias, como também com as narrativas de policiais militares e das delegadas da DEAM, que informaram que as prostitutas só buscam as delegacias em situações graves, nas quais são ameaçadas por cafetões ou clientes, e não conseguiram gerenciar por conta própria. Dessa forma, os "números" dialogam, em certa medida, com as entrevistas realizadas. Necessário, contudo, reiterar que os dados colhidos representam apenas uma parte ou indícios da realidade, mas eles também não podem ser alijados de consideração, principalmente para a compreensão desse fenômeno social.

A respeito dos arranjos arquitetônicos, por meio da observação flutuante, amplamente desenvolvida no Capítulo 1, foi possível perceber que a dinâmica da prostituição na W3 norte é compatível inclusive com ideologia de Brasília, cidade moderna, lógica e eminentemente planejada. Diante das "ausências das esquinas", a prostituição da W3 norte encontrou suas próprias estratégias, novamente, e apropriou-se do espaço de forma a aproveitar o fluxo dos

\footnotetext{
${ }^{192}$ Como já ressaltado, apesar de a polícia civil constituir polícia judiciária, ou seja, ter atribuição direta na investigação de condutas passíveis de crimes, é comum atribuições administrativas alheias à sua função constitucional, como o registro de extravio de documentos, acidentes de trânsitos que não constituam condutas delituosas ou mesmo desaparecimento de pessoas sem indícios de crime. Assim, de 101.069 ocorrências policiais registradas no período de 01/01/2010 a 31/12/2015 nas $2^{\text {a }}$ DP e DEAM, apenas 69.171 eram do tipo criminal e somente 121 registros tinham pertinência com a atividade de prostituição.
} 
carros em seu proveito e a constituir a avenida W3 norte em uma grande passarela, onde elas expõem seus corpos, habilidades e sensualidades, em um autêntico "trottoir-drive-thru".

Como o dispositivo é um conjunto de elementos heterônomos que se inter-relacionam, promovendo novos significados que, por sua vez são dinâmicos, já é possível relacionar os "dados criminais" com o próprio "arranjo arquitetônico" da apropriação do espaço acima narrado pela prostituição na W3 norte. Como visto, a comodidade para os clientes e prostitutas do que chamei de "trottoir drive-thru", favorece também a ocorrência de crimes, ao garantirem a furtividade e rapidez para a comercialização de drogas, conforme inferido nas análises das ocorrências (Capítulo 2) e também nas entrevistas dos policiais (Capítulo 4).

“Estatísticas criminais" e o "espaço nu”, porém, pouco significam se não for dada voz àqueles que estão diretamente relacionados à atividade de prostituição, as prostitutas, é claro, os clientes e os policiais militares e civis, que atuam na avenida W3 norte e que têm a prostituição como parte de seu cotidiano profissional ou lúdico.

Contudo, essas vozes que interpretam o que chamamos de realidade são impregnadas de perspectivas subjetivas, resultado de interpretações e ressignificações dos fatos pelos atores sociais com diferentes repertórios e histórias de vida. Novamente, são versões, ou pequenas apreensões de partes da realidade que, apesar da impossibilidade de representarem o todo, indicam notas fundamentais para sua compreensão.

É exatamente por isso que, utilizando como ferramenta a teoria das representações sociais de Serge Moscovici, a qual tratei com detalhes no capítulo introdutório, fiz várias considerações sobre as narrativas moral, religiosa, jurídica e social da prostituição ao longo dos tempos. Afinal, essas "representações se entrecruzam e se cristalizam continuamente, através duma palavra, dum gesto ou duma reunião em nosso mundo cotidiano. Elas impregnam a maioria de nossas relações estabelecidas, os objetos que nós produzimos ou consumimos e as comunicações que estabelecemos" (MOSCOVICI, 1976, p.40).

Não seria diferente com os nossos entrevistados e também comigo, que somos sujeitos a "cristalização" das representações sociais em nossas mentes, que, segundo Moscovici, apresenta-se por meio da ancoragem e da objetivação.

Em breve síntese, a ancoragem é um processo automático pelo qual transformamos algo estranho em familiar. Ela reflete a necessidade humana em categorizar tudo, um processo de encaixotamento, de colocar tudo na sua devida caixa ou categoria, mesmo que para tanto sejam necessários alguns ajustes na própria natureza do objeto a ser encaixotado (MOSCOVICI, 2007, p. 61). Já a objetivação, outra faceta da cristalização das representações sociais, destina-se a "reproduzir um conceito em uma imagem" (MOSCOVICI, 2007, p. 71). 
Interessante que, como vimos nos Capítulos 3 e 4, no qual foram expostas as entrevistas de prostitutas, clientes e policiais, verificamos vários exemplos da ancoragem, do encaixotamento, das vivências de cada um dos entrevistados em representações sociais cristalizadas nas diversas narrativas descritas no capítulo introdutório. É nesse ponto que se entrelaçam, por um lado, os discursos ou narrativas sociais, e, por outro, os ditos dos entrevistados.

Nesse contexto, mostra-se útil examinar com maior atenção como esse entrelaçamento se dá no âmbito das narrativas morais e médicas, até porque, em grande medida, a narrativa sociológica já foi bastante explorada ao longo do Capítulo 5, no contexto do estudo da prostituição a partir do olhar do campo intelectual feminista.

Dito isso, cabe lembrar que a narrativa moral é aquela que apresenta a prostituição como algo fundamentalmente errado, com base, regra geral, em considerações de ordem religiosa. No curso das entrevistas, a sua influência pode ser observada, por exemplo, na reiterada necessidade, por todos os atores envolvidos, principalmente entre clientes e policiais, de justificar a atividade de prostituição, de explicar as razões que levam a pessoa a se prostituir. A pessoa não pode simplesmente escolher ser prostituta. Ela tem que ter um motivo muito forte para tanto, seja a necessidade financeira seja a devassidão moral. Diante disso, alguém poderia argumentar que tal procedimento se dá, porque a prostituição é uma atividade muito árdua, exposta a uma série de riscos. Todavia, esse raciocínio não reflete a realidade. Existem outros trabalhos ainda mais duros e arriscados, como aquele dos operários das minas de carvão, e não se faz perguntas desse tipo para esses profissionais, ou ao menos esse tipo de questionamento não está presente no imaginário social. Assim, mostra-se muito mais provável que essa constante necessidade de justificação funcione como uma resposta ao pesado estigma que essa atividade ainda carrega consigo, mesmo diante de todos os avanços, nas últimas décadas, no sentido da liberalização sexual. E esse estigma está presente porque, consciente ou inconscientemente, o trabalho da prostituta é considerado ainda como moralmente reprovável. Observa-se que esse estigma é tão forte que a maioria das prostitutas entrevistadas no Capítulo 3 disse que a família não sabe e não pode saber de sua atividade profissional, e algumas delas, como Carol, relataram ter um grande temor de encontrar alguém que conhece "na pista".

Outro exemplo dessa relação entre prostituição e reprovabilidade moral encontra-se na vinculação, no imaginário social, entre prostituição e as ideias de "vida fácil" e "dinheiro fácil”, que está em contradição com o ethos, supostamente vigente na nossa sociedade ocidental, de que a recompensa econômica deve decorrer do trabalho duro. Como se viu, essa 
concepção é reproduzida, inclusive, na entrevista do policial militar Daniel e do cliente João. Todavia, vimos ao longo do trabalho que, ao menos na realidade da W3 norte, essa relação entre prostituição e "vida fácil” é fantasiosa. Inversamente, a vida da prostituta é muito árdua.

Em nenhuma das entrevistas, no entanto, foi reproduzida de forma expressa a narrativa de que a atividade de prostituição seria moralmente reprovável. O que se reuniu acima foram ecos dessa narrativa, manifestados de diversas formas ao longo das entrevistas. Isso constitui um indício de que, com a liberalização sexual das últimas décadas, tem-se tornado cada vez mais difícil, no espaço público, falar em tons pejorativos sobre a atividade de prostituição considerada em si mesma. Tanto é assim que, na cruzada dos moradores da 713/714 norte contra a prostituição na área, retratada em vários capítulos do presente trabalho, foi necessário associá-la ao tráfico ilícito de entorpecentes e à criminalidade em geral, para buscar maior apoio à causa.

Contudo, o advento desse discurso liberal não fez com que a narrativa moralista desaparecesse. Ele continua presente no dispositivo da prostituição na W3 norte, mas de uma maneira subterrânea, que se manifesta de forma mais desarticulada, como ecos.

A narrativa médica seguiu o mesmo caminho. Como visto no capítulo introdutório, ao longo do século XX, ela perdeu a sua capacidade de servir como narrativa legitimadora do poder repressivo estatal. Mas isso não significa que ela tenha desaparecido inteiramente do imaginário social. Assim como ocorreu com a narrativa moral, é possível encontrar ecos da narrativa médica nas palavras dos entrevistados.

Por exemplo, tratando da função da prostituição, o cliente Lucas colocou a prostituição como um serviço que tem como objetivo satisfazer certas necessidades naturais do homem, e que se mostra essencial quando, por qualquer motivo, não é possível satisfazer a sua libido no contexto de relacionamentos amorosos. Por outro lado, tratando das razões que levam uma mulher a se prostituir, o cliente Mateus declarou que, para ele, somente um desvio psicológico é capaz de explicar o fato de uma mulher se engajar nessa atividade, mesmo sem ser por extrema necessidade econômica.

Nessas falas, é possível encontrar dois dos grandes temas da narrativa médica, nos termos apresentados no capítulo introdutório: a prostituição como uma necessidade social; e a prostituta como uma pessoa dotada de uma perturbação psicológica. Nesses termos, observase que, mesmo com a sobreposição da narrativa médica por outras narrativas, fragmentos dessas narrativas continuam presentes no imaginário social.

Em suma, por mais que a sociedade brasileira encontre novas significações para as questões em torno da sexualidade como, por exemplo, o reconhecimento histórico e unânime 
pela Suprema Corte Constitucional a respeito do casamento de pessoas do mesmo sexo ${ }^{193}$, as representações sociais acerca da atividade de prostituição e também sobre o dispositivo de sexualidade encontram-se ainda impregnadas das narrativas ou discursos mencionados, que, por sua vez, são resultados de processos de ancoragem, cristalização e objetivação ao longo do tempo.

Simultaneamente, para a confecção do nosso dispositivo, além dos discursos, dos ditos, é preciso considerar também os não ditos e os interditos, que, de fato, são os mais difíceis de apreender a partir da observação do espaço, da análise de dados ou mesmo por meio de entrevistas. Contudo, é possível, após essa longa pesquisa, como já adiantado no Capítulo 4, inferir alguns interditos relacionados à atividade de prostituição, principalmente no que se refere ao próprio dispositivo de sexualidade, que, com as reflexões trazidas pela prostituição, mereceria uma nova roupagem, já que o dispositivo em si é um conceito dinâmico, como lembrou Bussolini ao descrevê-lo como a face do deus Janus (BUSSOLINI, 2010).

Um dos interditos inferidos diz respeito às relações de poder firmadas no âmbito da relação sexual, as quais constituiriam o que Bortolanza nominou de "micropolítica sexual" (BORTOLANZA, 2014, p. 271). Elas seriam pautadas por combinações promíscuas desvinculadas do dispositivo tradicional de sexualidade, do jogo da representação édipoconjugalidade-filiação-hereditariedade, mas, relacionadas diretamente com a realização de fantasias, desejos, em meio a relações objetivas e profissionais, e não afetivas e familiares. São novas interpretações que ousam contra estruturas e representações sociais familiares e sexuais já cristalizadas, ruídos ao tradicional dispositivo da sexualidade. Bortolanza considerou tais ideias, que constituem um dos interditos do dispositivo da prostituição da avenida W3 norte, como "um trottoir nos corredores da sexualidade que atraem o pensamento para este lugar sem lugar, para as zonas de promiscuidade (BORTOLANZA, 2014, p. 271). Afinal, os interditos ocupam esse espaço, um lugar sem lugar, a penumbra, as quatros paredes, tornados permeáveis pela objetivação e pelo anonimato.

Apesar de as narrativas moral, religiosa, médica, jurídica e social sobre a prostituição estarem ancoradas e objetivadas nas representações sociais na realidade da prostituição e também no dispositivo de sexualidade, ligado diretamente ao dispositivo de aliança (FOUCAULT, 1998, p. 100), lampejos de mudança foram observados na edição da Lei 12.015/2009, que, entre outros assuntos, modificou o Título VI da Parte Especial do Código

\footnotetext{
193 Na Ação de Descumprimento de Preceito Fundamental (ADPF), recebida como Ação Direta de Inconstitucionalidade (ADI) $n^{\circ}$ 4.277/DF, ajuizada pelo Procurador Geral da República, o STF conferiu interpretação conforme ao art. 1.723 do Código Civil para garantir a união estável e casamento entre pessoas do mesmo sexo.
} 
Penal Brasileiro, que trata, por exemplo de crimes como estupro, tráfico de mulheres, favorecimento da prostituição, de "crimes contra os costumes" para "crimes contra a dignidade sexual", expressão que se adequa à liberdade e ao desenvolvimento sexual da pessoa humana.

O antigo título "crimes contra os costumes" remete à defesa da moral, dos costumes, e não ao direito individual da mulher, na sua dignidade enquanto ser humano, passível de liberdade íntima e autonomia sexual. Apesar de a mudança ser alvissareira para a defesa dos direitos sexuais das mulheres, em relação aos crimes relacionados à atividade de prostituição, contudo, não houve mudanças significativas.

Como visto ao longo da pesquisa, a atividade de prostituição atua como um "toque do leproso", de forma que tudo que a prostituta tem a seu redor é contaminado pela promiscuidade, sujeira, imoralidade, devassidão e reprovação social a ela associadas no imaginário social. Assim, embora a mudança do Título VI da Parte Especial do nosso Código Penal tenha pretendido enaltecer a liberdade e a dignidade sexual da mulher, no caso da atividade de prostituição, essa liberdade encontra sérias limitações. Apesar de a atividade em si de prostituição não ser crime, e ser até regulamentada pela decisão regulamentara do Ministério do Trabalho e do Emprego, CBO 5.198-05, discutida nos Capítulos 2 e 3, realizar a prostituição de forma associada com outras prostitutas, de forma habitual, ou mesmo com um terceiro, de modo a garantir, por exemplo, a segurança de sua atividade, constituem condutas criminalizadas sobre os tipos penais de casa de prostituição e de favorecimento da prostituição ou outra forma de exploração da prostituição, descritos no capítulo introdutório. Ou seja, praticamente, a prostituta encontra-se sozinha, impedida de associar-se com terceiros ou outras prostitutas para melhorar o seu empreendimento ou mesmo garantir-lhe segurança.

A mudança do Código Penal ao fazer referência à proteção da dignidade sexual faz menção direta ao que seria dignidade humana, que, conforme constitucionalistas contemporâneos como Ronald Dworkin, tem uma dupla dimensão, por um lado, pelo reconhecimento da importância de cada projeto de vida individual, e por outro, por meio da proteção à autonomia individual na persecução desse projeto de vida (DWORKIN, 2006, p. 911). Assim, considerando a prostituição no contexto da dignidade sexual, pode-se dizer que a mudança no título do referido capítulo do Código Penal deveria trazer um maior reconhecimento da autodeterminação sexual da mulher, inclusive para eleger a prostituição como o caminho legítimo para a execução de seus projetos de vida, e, na medida em que não se trata de atividade ilegal, o Estado deve fomentar e garantir sua escolha. 
Nesse sentido, seria um bom sinal o avanço das discussões do PL 4.211/12, já tratado no Capítulo 3 e trazido na íntegra no Anexo 4, que trata da regulamentação da atividade de prostituição, e também de modificações no Código Penal atual, a fim de garantir que ela seja realizada de maneira associativa e proporcione outras interpretações à figura do cafetão, não como um explorador, mas como um sócio na atividade, desde que garanta efetiva proteção e liberdade à prostituta.

Ademais, necessária também a discussão sobre como estabelecer um reconhecimento legítimo à atividade de prostituição enquanto contrato de prestação de serviços passível de ser discutido e executado na esfera cível, a fim de se evitar o crime referente ao exercício arbitrário das próprias razões, o "fazer justiça com as próprias mãos", constantemente relatado na fala dos entrevistados, em especial no Capítulo 4. Afinal, quem não pode ter o acesso à Justiça formal, restar-lhe-ia o desenvolvimento de estratégias próprias ou "a sua própria Justiça".

São questionamentos que devem ser trazidos à discussão democrática com ampla liberdade de argumentação tanto por parte das prostitutas, as mais interessadas, quanto por parte das instituições acadêmicas, estatais e sociedade civil, de maneira sincera, sem interditos.

Ao longo do trabalho percebi a importância de observar os diferentes pontos de vistas e interpretações, que constituem mesmo uma rede de influências que se autodeterminam, criando outras significações, de forma que, conforme bem lembrou Deleuze (1992), o dispositivo ainda possui duas fundamentais características: o repúdio à universalidade, uma vez que ele é dinâmico e sua potencialidade autorreprodutiva e criativa, resultado da interação dessa rede relacional heterogênea.

As notas observadas até então sobre o dispositivo da prostituição na avenida W3 norte são assim dinâmicas, criativas e autorreprodutivas. Podemos dizer que essas são as versões colhidas hoje, mas quem sabe, mesmo com esse trabalho, essas versões possam ser modificadas, aprimoradas, em constante relação com o passado, presente e futuro, como as faces do deus Janus, característica própria do dispositivo.

Afinal, nunca conseguiremos apreender a verdade. Ela não existe, como disse no início. Existem só as versões. 


\section{Referências Bibliográficas}

ACERO, Misael Tirado. El debate entre prostitución y trabajo sexual. Una mirada desde lo socio-jurídico y la política pública. Revista de Relaciones Internacionales, Estrategia y Seguridad. Vol. 6. Núm. 1. Enero-junio, 2011. Pp. 127-148. Colômbia.

ANITUA, Gabriel Ignácio. Histórias dos pensamentos criminológicos. Tradução Sérgio Lamarão. Rio de Janeiro: Revan, 2008.

ARISTÓTELES. Política. Nova Cultural: São Paulo, 2000.

BARRETO, L. C. \& PRADO, M. A. M. Identidade das prostitutas em belo horizonte: as representações, as regras e os espaços. Pesquisas e Práticas Psicossociais 5(2), São João delRei, agosto/dezembro 2010.

BALDIN, Nelma; MUNHOZ, Elzira M. B. Snowball (bola de neve): uma técnica metodológica para pesquisa em educação ambiental comunitária. In: X Congresso Nacional de Educação. PUCPR: Curitiba, Anais. 07 a 10 de novembro de 2011.

BATISTA, Nilo. Introdução crítica ao direito penal. 12a ed. Rio de Janeiro: Revan, 2011.

BACHELARD, Gaston. A formação do espírito científico: contribuição para uma psicanálise do conhecimento. Tradução Estela dos Santos Abreu. Rio de Janeiro: Contraponto, 1996.

BECKER, Howard S. Outsiders: estudos de sociologia do desvio. Tradução de Maria Luiza Borges. Rio de Janeiro: Jorge Zahar, 2008.

BLANCHETTE, Thaddeus Gregory; SILVA, Ana Paula da e CAMARGO, Gustavo. Idealismo alemão e o corpo alienável: repensando a "objetificação" no contexto do trabalho sexual. In: Prostituição e outras formas de amor. Soraya Silveira Simões, Hélio R. S. Silva e Aparecida Fonseca Moraes (orgs.) Niterói: Editora da UFF, 2014. pp.146-181.

BORTOLANZA, Elaine. Zonas de promiscuidade: trottoir do desejo sexual. In: Prostituição e outras formas de amor. Soraya Silveira Simões, Hélio R. S. Silva e Aparecida Fonseca Moraes (orgs.) Niterói: Editora da UFF, 2014. pp.265-285.

BOURDIEU, P. Coisas ditas. Trad. por Cássia R. da Silveira e Denise Moreno Pegorim. SP: Brasiliense, 2004.

Razões Práticas: sobre a Teoria da Ação. $9^{\text {a }}$ Ed., trad. por Mariza Corrêa. Campinas, SP: Papirus, 2008.

Questões de Sociologia. Tradução de Jeni Vaitsman. Rio de Janeiro:

Marco Zero, 1983. P. 89. 
BUSSOLINI, Jeffrey. What is a Dispositive? In: Foucault Studies. N.10, pp. 85-107, November 2010.

BUTLER, Judith. Acerca del término 'queer'. In: Cuerpos que se importan Sobre los límites materiales y discursivos del « sexo ». BUTLER, Judith. Buenos Aires, Paidos, 2012. CALDEIRA, Júnia Marques. Uma investigação sobre a questão do espaço público. Cadernos de filosofia contemporânea. n.4. Rio de Janeiro, 2000. Pp. 26-39.

CAPELA, Gustavo Moreia. O direito à prostituição: aspectos de cidadania. Mestrado em Direito, Universidade de Brasília, Brasília, 2013.

CARUSO, Haydée. Entre ruas, becos e esquinas: por uma antropologia dos processos de construção da ordem na Lapa Carioca. Doutorado em Antropologia, Universidade Federal Fluminense, Niterói, 2009.

CASTRO, Edgardo. Vocabulário de Foucault - um percurso pelos seus temas, conceitos e autores. Tradução: Ingrid Müller Xavier. Belo Horizonte: Autêntica Editora, 2009.

COURTINE, Jean-Jacques. Decifrar o corpo: pensar com Foucault. Tradução: Francisco de Morás. Petrópolis, Rio de Janeiro: Vozes, 2013.

COLOGNESE, Silvio; MELO, José. L. Bica. A técnica de entrevista na pesquisa social. In: Pesquisa Social Empírica: Métodos e Técnicas. Cadernos de Sociologia. Porto Alegre: UFRGS, Nr. 9, 1998.

CORBIN, Alain. Maisons closes: cloaques ou paradis. Dossier les prostituées. In : Historia, octobre 2015, n. 826. Pp. 22-53.

CORBISIER, Roland. Brasília e o desenvolvimento nacional. Instituto Superior de Estudos Brasileiros: Rio de Janeiro, 1960.

COSTA, Lúcio. Brasília, cidade que inventei. Rio de Janeiro: Brasiliana, 1991.

COY, M. This body which is not mine. Feminist Theory. SAGE publications. Vol. 10 (1). 2009. London Metropolian University. Pp. 61-75.

CUNHA, Neiva Vieira. O Espírito do Sanitarismo: Narrativas de Profissionais da Saúde Pública dos anos 30. Tese de doutorado defendida no programa de Pós-Graduação em Sociologia e Antropologia da Universidade Federal do Rio de Janeiro, UFRJ, Brasil, 2002.

DAVIDSON, Julia O'Connel. The rights and wrongs of prostitution. Hypatia, Volume 17, Number 2, Spring 200, pp. 84-98.

DELEUZE, Gilles. 'What is a Dispositif?' in T.J. Armstrong (ed), Michel Foucault Philosopher. Hemel Hempstead: Harvester Wheatsheaf. pp. 159-168, 1992.

DEMEUDE, Hugues. Et Marthe Richard clôt le ébats. Dossier les prostituées. In : Historia, octobre 2015, n. 826. Pp. 22-53. 
DWORKIN, Ronald. Is democracy possible here?: principles for a new political debate. Princeton/Oxford: Princeton University Press, 2006.

EDWARDS, S., The legal regulation of prostitution: a human rights issue, in G. Scambler and Scambler, A. Re-thinking Prostitution, Routledge, London, 1997.

FOUCAULT, Michel. A ordem do discurso. Aula inaugural no Collège de France, pronunciada em 2 de dezembro de 1970. Tradução: Laura Fraga de Almeida Sampaio. 12a ed. São Paulo: Edições Loyola, 2005A.

. A Arqueologia do Saber. Tradução: Luiz Felipe Baeta Neves. $7^{\mathrm{a}}$ ed. Rio de Janeiro: Forense Universitária, 2005B.

A história da sexualidade I. A vontade de saber. Tradução: Maria Thereza da Costa Albuquerque e J. A. Guillhon Albuquerque. 13ª ed. Rio de Janeiro: Graal, 1998.

FRANCO, Alberto Silva (Coord.). Código Penal e sua Interpretação, doutrina e jurisprudência. São Paulo: Editora Revista dos Tribunais, 2007.

FRANCO, Maria Laura Puglisi Barbosa. Análise de Conteúdo. Brasília, $3^{\text {a }}$ ed.: Liber Livro Editora, 2008.

GABRIS Aurora \& BANCIU, Viorica (trad.) (2009), The Prostitution from Offense to Decriminalization In ,Analele Universităţii din Oradea, Fascicula Sociologie-FilosofieAsistenţă Socială”, Nr. IX, 2009, pp. 101-107.

GAVILHA, Juliana. As redes das ruas: seus lugares, fluxos e itinerários. In: Prostituição e outras formas de amor. Soraya Silveira Simões, Hélio R. S. Silva e Aparecida Fonseca Moraes (orgs.) Niterói: Editora da UFF, 2014. P.319-365.

GEERTZ, Clifford. A interpretação das culturas. 1ª ed. Rio de Janeiro, LTC, 2013.

GOFFMAN, Erving. Estigma: notas sobre a manipulação da identidade deteriorada. Tradução de Márcia Nunes. 4. ed. Rio de Janeiro: Guanabara Koogan, 1988.

Comportamentos em lugares públicos: notas sobre a organização social dos ajuntamentos . Petrópolis: Vozes, 2010.

GOULD, Arthur. The Criminalisation of Buying Sex: the Politics of Prostitution in Sweden. Journal of Social Policy, Cambrigde, 30, 2001, pp 437-456

GROSZ, Elizabeth. Corpos reconfigurados. In: Cadernos Pagu (14). Campinas: Unicamp, 2000, pp45-86.

GROSZ, Elisabeth. Bodies-Cities. In: COLOMINA, Beatriz. Sexuality and Space. New Jersey: Princeton University School of Architecture, 1990. Pp. 241-253.

GUIMARÃES, Katia e MERCHÁN-HAMANN, Edgar. Comercializando fantasias: a representação social da prostituição, dilemas da profissão e a construção da cidadania. 
Estudos Feministas. Florianópolis, 13(3): 525-544, setembro-dezembro/2005

HASSEMER, Winfried \& CONDE, Francisco Muñoz. (2001) Introducción a la Criminología. Valencia, Tirant lo Blanch.

HUNGRIA, Nelson, LACERDA, Romão Cortês, e FRAGOSO, Heleno Cláudio. Comentários ao Código Penal, v. VIII. $5^{\text {a }}$ Ed. Forense: Rio de Janeiro, 1981.

HUGHES, Everett. The sociological eye. New Jersey: Ney Brunswick, 1993.

HUlSMAN, Louk; CELIS, Jacqueline Bernat de. Penas Perdias. O sistema penal em questão. Tradução Maria Lucia Karan. 2a ed. LUAM: Niterói, 1997.

JACOBS, Jane. Morte e vida de grandes cidades. Martins Fontes, São Paulo, $1^{\text {a }}$ ed., 2000.

JESUS, Damásio de. Direito Penal, v. 3. 14 a Ed. Saraiva: São Paulo, 1999.

JÚNIOR, Aury Lopes. Direito Processual Penal, 9ª Ed. Saraiva: São Paulo, 2012.

KANT, Immanuel. Fundamentação da Metafísica dos costumes e outros escritos. Tradução de Leopoldo Holzbach. Martin Claret: São Paulo, 2002.

KANT DE LIMA, Roberto. Polícia e exclusão na cultura judiciária. Tempo Social; Rev. Sociol. USP, S. Paulo, 9(1): 169-183, maio de 1997.

KRAMER, Heinrich e SPRENGER, James. O Martelo das Feiticeiras, trad. FRÓES, Paulo, MURARO, Rose Marie e BYINGTON, Carlos. Rio de Janeiro, BestBolso, 2015.

LAGRAVE, R.M. 1990. "Recherches féministes ou recherches sur les femmes?" in Actes de la Recherche en Sciences Sociales, Paris, $n^{\circ} 83$.

LEITE, Gabriela Silva. Eu, mulher da vida. Rio de Janeiro: Rosa dos tempos, 1992.

LIMA, Rita de Cássia Pereira. (2001), "Sociologia do desvio e interacionismo". Revista de Sociologia da Universidade de São Paulo, volume 13 (1): 185-201.

LOMBroso, Cesare e FERRERO, Guglielmo. Criminal Woman, the Prostitute and the Normal Woman. Tradução de Nicole Hahn Rafter e Mary Gibson. Duke University Press: Londres e Durhan, 2004, edição para Kindle.

MACHADO, Carla. Crime e insegurança. Discursos do medo, imagens do outro. Notícias editorial: Lisboa, 2004.

MACHADO, Lia Zanotta. Campo Intelectual e Feminismo: Alteridade e Subjetividade nos Estudos de Gênero. In: Série Antropologia, n. 170. Brasília: Universidade de Brasília, 1994.

MACKINNON, Catherine. Pornography, Civil Rights and Speech. Harvard Civil RightsCivil Liberties Law Review, v. 20, n.1. 1985.

MAGNANI, José Guilherme Cantor. "Quando o campo é a cidade: fazendo antropologia na metrópole." In: Na metrópole - Textos da Antropologia Urbana. José Guilherme C. Magnani \& Lilian de Lucca Torres (org.). EDUSP, São Paulo, 1996. Pp. 1-30. 
MAGNANI, José Guilherme Cantor. "Rua, símbolo e suporte da experiência urbana". Cadernos de História de São Paulo 2, jan/dez, 1993, Museu Paulista - USP.

MAGnani, José Guilherme Cantor. Festa no Pedaço: Cultura Popular e Lazer na Cidade. São Paulo, Hucietec, 1998.

MANNONI, Pierre. Les représentations sociales. $6^{\mathrm{a}}$ ed. Paris: Presses Universitaires de France, 2006.

MARTINS, Carlos Benedito Campos. Notas sobre a Noção da Prática em Pierre Bourdieu. In: Novos Estudos n. 62. UF: Editora, 2002.

MARTINS, Carlos Benedito Campos. O legado do Departamento de Sociologia de Chicago (1920-1930) na constituição do interacionismo simbólico. Sociedade e Estado. [online]. 2013, vol.28, n.2, pp.217-239.

MATOS, Marlise. Teorias de gênero ou teorias e teorias de gênero ou teorias e gênero? Se e como os estudos de gênero? Se e como os estudos de gênero e feministas se gênero e feministas se transformaram em um transformaram em um transformaram em um campo novo para as ciências para as ciências. Estudos Feministas, Florianópolis, 16(2): 440, maioagosto/2008.

MAZZARIOL, Regina Maria. Mal necessário. Ensaio sobre o confinamento da prostituição na cidade de Campinas. Dissertação de mestrado em Ciências Sociais da Universidade de Campinas, 1976.

MELlO, Marco Antônio da Silva; CUNHA, Neiva Vieira. Rito e Símbolo na Cosmologia do Sanitarismo: Considerações sobre a história e a memória urbana do Rio de Janeiro. Candelária (Rio de Janeiro), v. 3, p. 156-172, 2005.

MISKOLCI, Ricardo. A teoria queer e a sociologia: o desafio de uma analítica da normalização. Sociologias, Porto Alegre, ano 11, n. 21, jan./jun. 2009, p. 150-182.

MOSCOVICI, Serge. Representações sociais: investigações em psicologia social. Tradução de Pedrinho A. Guareschi. 5a ed. Petrópolis: Vozes, 2007

MORAES, Aparecida Fonseca. Mulheres da Vila. Prostituição, identidade social e movimento associativo. Petrópolis, Rio de Janeiro: Vozes, 1995.

MURARO, Rosa Marie. Introdução ao Martelo das Feiticeiras. In: O Martelo das Feiticeiras. Rio de Janeiro, BestBolso, 2015.

NUCCI, Guilherme de Souza. Crimes contra a dignidade sexual: comentários à Lei 12.015, de 7 de agosto de 2009. São Paulo: Editora Revista dos Tribunais, 2009. 
OLIVAR, José Miguel Nieto. Banquete de homens. Sexualidade, parentesco e predação na prática da prostituição feminina. Revista brasileira de Ciências Sociais, vol. 26, n. 75, fevereiro, 2011.

OLIVEIRA, Roberto Cardoso. O trabalho do antropólogo. $2^{\mathrm{a}}$ ed. Brasília: Paralelo15; São Paulo: Editora UNESP, 2000.

PARK, Robert Ezra. "A cidade: sugestões para a investigação do comportamento humano no meio urbano." Trad. Sérgio Magalhães Santeiro. In: O fenômeno urbano. Otávio Guilherme Velho (org.), Rio de Janeiro, Zahar, 1973, 2ª ed. Pp. 25-66.

PÉTONNET, Colette. Observação flutuante: o exemplo de um cemitério parisiense. Tradução de Soraya Silveira Simões. Antropolítica. Niterói, n. 25, p. 99-111. 2. sem. 2008.

PISCITELLI, Adriana. "Re-criando a (categoria) mulher." Textos didáticos 48, p 7-42, 2002.

PORTO, Maria Stela Grossi. Sociologia da Violência do conceito às representações sociais. Brasília: Verbana Editora, 2010.

PRADO, Luiz Régis. Tratado de Direito Penal Brasileiro: Parte Especial. V. 5. São Paulo: Editora Revista dos Tribunais, 2014, p. 539.

Curso de Direito Penal Brasileiro, v. 3, 4ª Ed. São Paulo: RT, 2006.

RAFFNSØE, Sverre “Qu'est-ce qu'un dispositif? L'analytique sociale de Michel Foucault,"Symposium (Canadian Journal of Continental Philosophy / Revue canadienne de philosophie continentale): Vol. 12: Iss. 1, Article 5, 2008.

RAGO, Margareth. Os prazeres da noite: prostituição e códigos da sexualidade feminina em São Paulo, 1890-1930. Rio de Janeiro: Paz e Terra, 1991.

RAMOS, Diane Helene. "Preta, pobre e puta": a segregação urbana da prostituição em Campinas - Jardim Itatinga. Doutorado em Planejamento Urbano e Regional, Universidade Federal do Rio de Janeiro - UFRJ, 2015.

RODRIGUES, Marlene Teixeira. Polícia e prostituição feminina em Brasília - um estudo de caso. Doutorado em Sociologia, Universidade de Brasília, Brasília, 2003.

Prostituição e polícia em Brasília na década de 1990. A segurança pública no Distrito Federal. Org. Arthur Costa e Lourdes Bandeira. Brasília: Editora LGE, 2007. p. 135163.

RODRIGUES, Raymundo Nina. Os Africanos no Brasil [online]. Rio de Janeiro: Centro Edelstein de Pesquisas Sociais, 2010.

SANDERS, T. Controlling the 'anti sexual' city: Sexual citizenship and the disciplining of female street sex workers. Criminology and Criminal Justice. 9 (4). 2009. P. 507-525. 
SANTOS, Boaventura de Sousa. "Da ciência moderna ao novo senso comum”. In: A Crítica da Razão Indolente - contra o desperdício da experiência. São Paulo: Cortêz, 2000. Capítulo 2, p. 119 - 189.

SANTOS, Gilmar Bueno. O estilo interativo das profissionais do sexo de Belo Horizonte: um estudo sobre estratégias linguísticas. Tese (Doutorado, PPG em Letras) - Universidade Federal de Minas Gerais, Belo Horizonte, 2011.

SCOUlAR, Jane. The 'Subject' of Prostitution. Novembro, 2010. Disponível em: $\underline{\text { http://ssrn.com/abstract }=1701618 \text { or http://dx.doi.org/10.2139/ssrn.1701618 }}$

SESHU, M. S; PAI, Aarthi. Sex work undresses patriarchy with every trick. Bulletin. Volume 45. Number 1. January 2014.

SHRAGE, L. Should Feminists oppose prostitution. Ethics. Vol. 99. N. 2 (Jan, 1989) pp. 347361. The University of Chicago Press.

SIMMEL, Georg. "Algumas reflexões sobre a prostituição no presente e no futuro (1892)". In: Filosofia do Amor. Tradução Eduardo Brandão. $3^{a}$ ed. São Paulo: Martins Fontes, 2006.

As grandes cidades e a vida do espírito. MANA 11 (2):577-591, 2005

"A metrópole e a vida mental." Trad. Sérgio Marques dos Reis. In: O fenômeno urbano. Otávio Guilherme Velho (org.), Rio de Janeiro, Zahar, 1973, 2ª ed. Pp. 1024.

SIMÕES, Soraya Silveira. Vila Mimosa: etnografia da cidade cenográfica da prostituição carioca. Rio de Janeiro, EDUFF, 2009.

SIMÕES, Soraya Silveira. Planned cities, real cities: prostitution and the production of a critical urban narrative. In:

http://www.30rba.abant.org.br/simposio/view?ID_MODALIDADE_TRABALHO=2\&ID_SI MPOSIO $=50$

SILVA, Ronaldo Alves. As práticas informacionais das profissionais do sexo da zona boêmia de Belo Horizonte. Mestrado em Ciência da Informação, Universidade Federal de Minas Gerais, 2008.

SILVA, Gilvan Gomes. A construção do suspeito na lógica da polícia militar do DF. Mestrado em Sociologia, Universidade de Brasília, 2009.

SOARES, Dulce (org.). Brasília: Guiarquitetura. Empresa das Artes: São Paulo, 2000.

SUÁREZ, Mireya. Desconstrução das categorias de “mulher" e "negro". Série Antropologia, 133, 1ª ed., Brasília, Departamento de Antropologia, Universidade de Brasília, 1992. 
SZYMANSKI, Heloisa. A entrevista na educação: a prática reflexiva. $4^{\text {a }}$ ed. Brasília: Liber Livro Editora, 2011.

TEIXEIRA, Marcelo Augusto de Almeida. Presença incômoda: corpos dissidentes na cidade modernista. Mestrado em Arquitetura, Universidade de Brasília, Brasília, 2013.

WIRTH, Louis. O urbanismo como modo de vida. In: Otávio G. Velho (org.). $\underline{\text { O fenômeno }}$ urbano. Rio de Janeiro: Ed. Guanabara, 1967. p. 89-112.

ZAFFARONI, Eugenio Raul e BATISTA, Nilo. Direito Penal Brasileiro, v. 1. Rio de Janeiro: Editora Revan, 2003. 


\section{Anexos}

\section{Anexo 1 - O modelo de boletins de ocorrência}

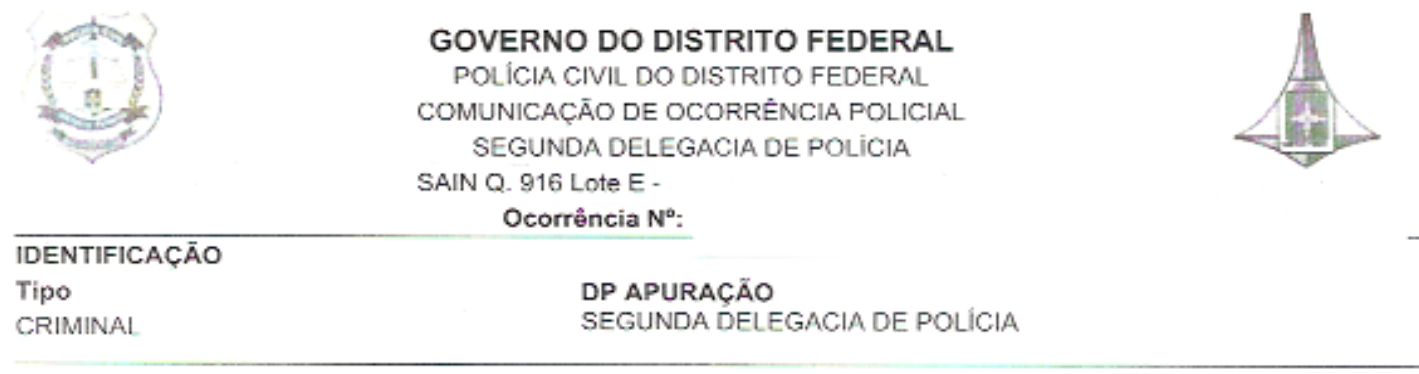

\section{DADOS BÁSICOS}

Natureza đa Ocortẻncia: LESĀo CORPORAL DE NATUREZA GRAVE/GRAVISSIMA

Data da Comunicaça: $19 / 11 / 2012$ às 12:09 Origem da Comunicaçăo: PÚBLICO

Data do Fato: $\quad$ 18/04/2012 as 03:00 (Quarta-Feira)

Endereço do Fato: $\quad$ SCLRN 712, PARADA DE ONIBUS, ASA NORTE.

Cidade / UF: BRASILIA/ DISTRITO FEDERAL

Pralicauto por menor: Ignorado Gravidade das Lesర̄es: lleso

Local Periciado: Não

CONDIÇŌES LOCAIS - CRIMINAL

Tipo Local: Descrição Local: ZONA RURAL

Objeto/Meio Empregado: VIOLÉNCIA FISICA.

\section{PESSOAS ENVOLVIDAS}

Nome:

Envolvimento:

Mäe:

Nacionalidade:

Data de Nascimento:

Idade:

Sexo:

Identidade:

Grau de Instrução: $\quad$ MÉDIO $\left(Z^{\circ} \mathrm{G}\right)$

Estado Civil: $\quad$ SOLTEIRO(A)

Profissão: Prostituta

Orgäo/Empresa: AUTONOMA

Cargo/Funçāo: $\quad$ PROSTITUTA

Endereco Residencial:

Estado:

Telefone Celular:

CPF:

Gravidade das Lesbes: Ignorada

\section{Nome:}

\section{NĀO IDENTIFICADO}

$\begin{array}{ll}\text { Envolvimento: } & \text { AUTORIA CONHECIDA, NĀO IDENTIFICADO / AUTOR } \\ \text { Nacionalidade: } & \text { BRASILEIRA }\end{array}$

Sexo: Masculino

Gravidade das Lesoes: Ignorada

\section{HISTÓRICO}

A comunicante 


\section{Anexo 2 - Perfis dos entrevistados}

Neste anexo, estão informação básicas sobre os entrevistados. Contudo, alguns desses entrevistados pediram que não fossem identificados no presente trabalho. Assim, parte dos dados trazidos abaixo foram registrados de forma a dificultar a individualização desses entrevistados. Por exemplo, no segmento referente aos clientes, indiquei, genericamente, que todos são servidores públicos, sem especificar as suas carreiras específicas. Isso porque, conjuntamente com as demais informações trazidas no texto, essa informação poderia levar à sua identificação, ao menos pelas pessoas que lhes são mais próximas, e não conhecem essas histórias.

Feitas essas ressalvas, vamos aos perfis.

\section{Prostitutas}

$\mathrm{Na}$ tabela abaixo, registrei as principais informações sobre as prostitutas entrevistadas.

\section{Tabela 3. Perfis das prostitutas entrevistadas}

\begin{tabular}{|l|l|l|l|l|l|l|l|l|l|}
\hline & Idade & Gênero & $\begin{array}{l}\text { Onde } \\
\text { mora? }\end{array}$ & $\begin{array}{l}\text { Estado } \\
\text { civil }\end{array}$ & $\begin{array}{l}\text { Tem } \\
\text { filhos? }\end{array}$ & $\begin{array}{l}\text { Tempo na } \\
\text { prostituição }\end{array}$ & $\begin{array}{l}\text { Família } \\
\text { sabe } \\
\text { atividade? } \\
\text { da }\end{array}$ & $\begin{array}{l}\text { Renda } \\
\text { mensal } \\
\text { média }\end{array}$ & $\begin{array}{l}\text { Tem } \\
\text { proje } \\
\text { to de } \\
\text { sair } \\
\text { da } \\
\text { pista? }\end{array}$ \\
\hline Renata & 25 & Mulher & Guará & Solteira & Não & 1 ano & Não & --- & Sim \\
\hline Letícia & 30 & Mulher & Sobradinho & Solteira & Sim & 5 anos & Sim & 3.500 & Sim \\
\hline Vanessa & 24 & Travesti & Asa Norte & Casado & Não & 8 anos & Sim & 4.500 & Sim \\
\hline Layane & 22 & Travesti & $\begin{array}{l}\text { Goiânia } \\
\text { Brasília }\end{array}$ & Namoro & Não & 5 anos & Sim & 3.000 & --- \\
\hline Bel & 20 & Mulher & $\begin{array}{l}\text { Goiânia } \\
\text { Brasília }\end{array}$ & Solteira & Não & 1 anos & Não & --- & --- \\
\hline Su & --- & Travesti & Taguatinga & Solteiro & Não & 10 anos & Sim & --- & Não \\
\hline Mônica & 38 & Mulher & Paranoá & Solteira & Sim & 11 anos & Não & -- & --- \\
\hline Bia & 22 & Mulher & ---- & Solteira & Não & ---- & Não & --- & ---- \\
\hline Carol & 23 & Mulher & Valparaíso & Solteira & Não & 1 ano & Não & 4.000 & Não \\
\hline Priscilla & 37 & Mulher & Itapoã & Solteira & Não & 2 anos & Não & 4.000 & --- \\
\hline
\end{tabular}

\section{Policiais civis}

No que tange ao registro das ocorrências (Capítulo 2), foram entrevistados 3 policiais civis. Todos eles tinham, no mínimo, 10 anos de carreira, e 5 anos na região da Asa Norte, que abrange a área da W3 Norte. 
Já sobre os dois policiais civis entrevistados sobre o envolvimento das prostitutas com a criminalidades, eles têm, no mínimo, 6 anos de polícia, 2 deles na Asa Norte.

\section{Policiais militares}

Todos os policiais militares entrevistados, ao total de 5, atuam há mais de 10 anos na região da Asa Norte, inclusive na área da W3 Norte.

\section{Clientes}

As informações dos clientes estão apresentadas na seguinte tabela:

Tabela 4. Perfis dos clientes entrevistados

\begin{tabular}{|l|l|l|l|l|}
\hline & Idade & Trabalho & $\begin{array}{l}\text { Já teve envolvimento } \\
\text { amoroso com prostituta? }\end{array}$ & $\begin{array}{l}\text { Tempo como } \\
\text { cliente }\end{array}$ \\
\hline João & 36 & Servidor Público & Sim & 18 anos \\
\hline Lucas & 34 & Servidor Público & Não & --- \\
\hline Mateus & & Servidor Público & --- & --- \\
\hline Marcos & 37 & Servidor Público & Sim & 19 anos \\
\hline Lourival & 36 & Servidor Público & Não & --- \\
\hline
\end{tabular}

\section{Outros (Rampazzo, comunidade)}

Arthur Rampazzo é proprietário site de acompanhantes "Capital Sex”, que tem como objetivo a divulgação de anúncios de serviços de prostituição de mulheres, homens e travestis. 


\section{Anexo 3 - Roteiro das entrevistas semiestruturadas}

\section{Prostitutas}

- O que você acha da regulamentação da atividade de prostituição? ${ }^{194}$

- Há quanto tempo você é prostituta?

- Onde você mora?

- Você tem filhos?

- Como você entrou para a prostituição? Há quanto tempo trabalha aqui na W3 norte como prostituta?

- Por qual motivo você entrou para a prostituição?

- Sua família e amigos próximos sabem da sua atividade de prostituição? Em caso positivo, qual foi a reação deles?

- Como é a dinâmica do trabalho da prostituição?

- Você já anunciou o seu trabalho em sites ou jornais?

- Como é o seu dia-a-dia?

- Quanto você ganha por mês?

- Como você se diverte?

- Quais são seus projetos de vida?

- Como é a sua relação com os clientes?

- Você sente medo na sua atividade? De que e de quem?

- Na sua experiência, qual é a relação entre prostituição e criminalidade?

- Como é a relação com a polícia?

- Como é a relação com a vizinhança?

\section{Policiais civis que registram as ocorrências}

- Há quanto tempo você é policial civil?

- Há quanto tempo você trabalha na Asa Norte?

- Você registra muitas ocorrências relacionadas à prostituição?

- Como você identifica que essa ocorrência se relaciona à prostituição? A própria

\footnotetext{
${ }^{194}$ Essa pergunta foi feita, em primeiro lugar, para "quebrar o gelo" com a prostituta, e facilitar o restante da entrevista.
} 


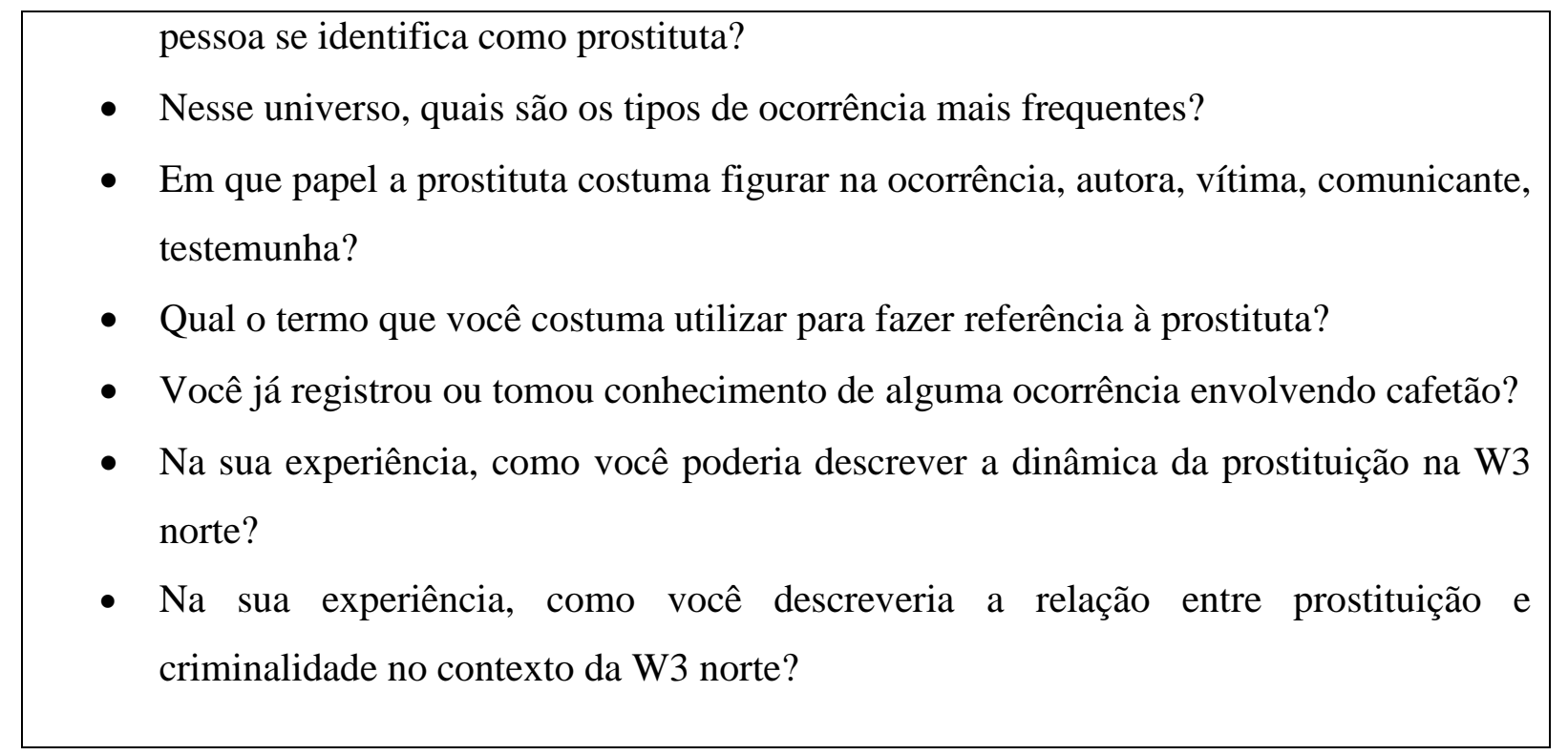

\section{Policiais que realizam investigações na área da $\mathrm{W3}$ norte}

A entrevista com os investigadores deu-se de forma livre, sem seguir um roteiro prédeterminado, nem mesmo semiestruturado, a não ser quantos aos elementos de identificação, descritos sinteticamente no Anexo 3.

\section{Policiais militares}

- Há quanto tempo você é policial militar?

- Há quanto tempo você trabalha na Asa Norte?

- Como funciona a atuação da Polícia Militar na W3 Norte?

- Como é a dinâmica da prostituição na W3 norte?

- Como funciona a distribuição espacial das prostitutas na W3 norte?

- Quanto as prostitutas ganham?

- Quem são os clientes da prostituição na W3 norte?

- Por que as mulheres se tornam prostitutas?

- Você acha que elas sofrem violência nos programas ou se envolvem com a criminalidade?

- Como funciona a questão do cafetão?

- O que você acha da regulamentação da prostituição? 


\section{Clientes}

- Por que a pessoa procura o serviço de prostituição?

- Qual é o método que você utiliza para encontrar e selecionar os programas?

- Como começou a utilizar o serviço de prostituição?

- Existe um tipo de homem que busca o serviço de prostituição? Consegue classificar esses homens em tipos mais específicos?

- Já teve um relacionamento mais estreito com alguma prostituta? Como foi?

- Quais são as perspectivas e sonhos de futuro das prostitutas?

- Você vê a prostituta como um objeto sexual do homem?

- Pelo seu conhecimento, por que uma mulher resolve entrar para a prostituição?

- Quais as estratégias que elas têm para se defender?

- Considera a prostituição um trabalho como todos os outros?

- Onde elas aprendem a sua atividade profissional?

- Como é a relação da prostituta com o cafetão?

- Como é a relação da prostituta com as outras prostitutas?

- O que acha daquela ideia de que a prostituta é suja ou portadora de doenças?

- Já realizou programas na W3 norte? Como foi?

- Quais dias você busca programas na W3 norte?

- Considera perigoso fazer programa na W3 norte?

- Há uma separação entre prostitutas e travestis na W3 norte?

- Qual a diferença entre as prostitutas da W3 e as do site?

- Por que acabou a prostituição na 715 norte?

- O que acha sobre a regulamentação?

\section{Outros}

A entrevista com Arthur Rampazzo ocorreu de forma livre, sem seguir um roteiro prédeterminado, nem mesmo semiestruturado, a não ser quantos aos elementos de identificação, descritos sinteticamente no Anexo 3. 


\section{Anexo 4 - Projeto de Lei Gabriela Leite}

O Congresso Nacional Decreta:

Art. $\mathbf{1}^{\mathbf{0}}$ - Considera-se profissional do sexo toda pessoa maior de dezoito anos e absolutamente capaz que voluntariamente presta serviços sexuais mediante remuneração.

$\S 1^{\mathrm{o}}$ É juridicamente exigível o pagamento pela prestação de serviços de natureza sexual a quem os contrata.

$\S 2^{\circ}$ A obrigação de prestação de serviço sexual é pessoal e intransferível.

Art. $\mathbf{2}^{\mathbf{0}}$ - É vedada a pratica de exploração sexual.

Paragrafo único: São espécies de exploração sexual, além de outras estipuladas em legislação especifica:

I- apropriação total ou maior que 50\% do rendimento de prestação de serviço sexual por terceiro;

II- o não pagamento pelo serviço sexual contratado;

III- forcar alguém a praticar prostituição mediante grave ameaça ou violência.

Art. $3^{\mathbf{0}}$ - A/O profissional do sexo pode prestar serviços:

I - como trabalhador/a autônomo/a;

II - coletivamente em cooperativa.

Paragrafo único. A casa de prostituição é permitida desde que nela não se exerce qualquer tipo de exploração sexual.

Art. $4^{\mathbf{0}}$ - O Capitulo V da Parte Especial do Decreto-Lei no 2.848, de 7 de dezembro de 1940, Código Penal, passa a vigorar com as seguintes alterações:

\section{“Favorecimento da prostituição ou da exploração sexual.}

Art. 228. Induzir ou atrair alguém à exploração sexual, ou impedir ou dificultar que alguém abandone a exploração sexual ou a prostituição:

\section{"Casa de exploração sexual}

Art. 229. Manter, por conta própria ou de terceiro, estabelecimento em que ocorra exploração sexual, haja, ou não, intuito de lucro ou mediação direta do proprietário ou gerente:

\section{Rufianismo}


“Art. 230. Tirar proveito de exploração sexual, participando diretamente de seus lucros ou fazendo-se sustentar, no todo ou em parte, por quem a exerça:

“Art. 231. Promover a entrada, no território nacional, de alguém que nele venha a ser submetido à exploração sexual, ou a saída de alguém que vá exercê-la no estrangeiro.

“Art. 231-A. Promover ou facilitar o deslocamento de alguém dentro do território nacional para ser submetido à exploração sexual:

Art. $5^{\circ}$. O Profissional do sexo terá direito a aposentadoria especial de 25 anos, nos termos do artigo 57 da Lei 8.213, de 24 de julho de 1991.

Art. $6^{0}$. Esta Lei entra em vigor na data da sua publicação. 